UNIVERSIDADE DE SÃO PAULO

Faculdade de Arquitetura e Urbanismo

\title{
A SUSTENTABILIDADE APOIADA PELAS POLÍTICAS URBANAS FEDERAIS E ESTADUAIS: O CASO DE GOVERNADOR VALADARES, JuIz de Fora, Montes Claros, Poços de CALdAS E UBERLÂNDIA - MG
}

ELISABETE DE ANDRADE 
ELISABETE DE ANDRADE

\section{A SUSTENTABILIDADE APOIADA PELAS POLÍTICAS URBANAS FEDERAIS E ESTADUAIS: O CASO DE GOVERNADOR VALADARES, JuIz de Fora, Montes Claros, Poços de CALdAS E UBERLÂNDIA - MG}

Tese apresentada à Faculdade de Arquitetura e Urbanismo da Universidade de São Paulo para obtenção do título de Doutor em Arquitetura e Urbanismo.

Área de Concentração: Planejamento Urbano e Regional

Orientador: Prof. Drª Gilda Collet Bruna 


\section{FOLHA DE APROVAÇÃO}

ANDRADE, Elisabete de. A sustentabilidade apoiada pelas políticas urbanas federais e estaduais: o caso de Governador Valadares, Juiz de Fora, Montes Claros, Poços de Caldas e Uberlândia - MG.

Tese apresentada à Faculdade de Arquitetura e Urbanismo da Universidade de São Paulo para obtenção do título de Doutor em Arquitetura e Urbanismo.

Área de Concentração: Planejamento Urbano e Regional

Aprovado em:

Banca examinadora

Prof. Dr.

Instituição:

Assinatura

Prof. Dr.

Instituição:

Assinatura

Prof. Dr.

Instituição:

Assinatura

Prof. Dr.

Instituição:

Assinatura 
Aos meus queridos, Tico e Chico, que passaram tanto tempo em esforço de tese... 


\section{AGRADECIMENTOS}

À minha orientadora, Professora Drạ. Gilda Collet Bruna, pelo encaminhamento científico, e pela compreensão maternal;

Aos professores das Bancas de Qualificação às quais fui submetida, Professor. Dr. José Eduardo de Assis Lefèvre e Professor Dr. Wilson Edson Jorge, pela contribuição dada ao desenvolvimento do trabalho;

Às funcionárias da Secretaria da Pós-Graduação e da Biblioteca da FAU, pela cordialidade no atendimento e encaminhamento dos sempre necessários processos;

À arquiteta Professora Drª̣. Maria Inês de Paula, pelos incentivos e auxílios;

Às arquitetas Professora Dra . Maria das Graças Ferreira e Professora Drª̣. Maria Cristina Villefort Teixeira pelos auxílios teóricos - e práticos da vida.

A todos os funcionários das prefeituras municipais que me atenderam com paciência e cordialidade. Meu agradecimento é imperceptível perto da importância deles para este país.

À minha família, que me viu "ir pra lá, ir pra cá"...

Ao Centro Universitário Izabela Hendrix e à Universidade FUMEC pelo apoio e colaboração nos períodos das ausências de minhas atividades docentes. 
Queremos saber, queremos viver Confiantes no futuro Por isso se faz necessário prever Qual o itinerário da ilusão A ilusão do poder Pois se foi permitido ao homem

Tantas coisas conhecer É melhor que todos saibam O que pode acontecer

Queremos saber Gilberto Gil 


\section{RESUMO}

ANDRADE, Elisabete de. A sustentabilidade apoiada pelas políticas urbanas federais e estaduais: o caso de Governador Valadares, Juiz de Fora, Montes Claros, Poços de Caldas e Uberlândia - MG. 2006. 222p. Orientador: Gilda Collet Bruna. FAUUSP, São Paulo.

O presente trabalho tem por objetivo verificar se as políticas públicas teriam sido capazes de dotar o ambiente urbano de sustentabilidade. Com este propósito, são analisados os Planos Nacionais de Desenvolvimento encaminhados pelo governo federal no período de 1972 a 1985, buscando evidenciar as propostas para o desenvolvimento urbano contido em cada um deles. Dentre estas, é dado destaque ao Programa Nacional de Cidades Médias e, procurando fazer um recobrimento temporal dentro planejamento determinado pelo governo do Estado de Minas Gerais, ao Programa Estadual de Centros Intermediários. A ampliação da discussão sobre a questão ambiental no mundo, após as sucessivas crises de abastecimento, é colocada através de uma revisão dos textos das Conferências Mundiais sobre Meio Ambiente e sobre Assentamentos Humanos, para que possam ser definidos critérios que necessariamente deveriam estar contidos em uma análise de "sustentabilidade do ambiente urbano". São definidos alguns parâmetros daquilo que seria recomendável estar presente em um ambiente urbano que se pretenda mais "sustentável". Estes parâmetros qualificados como necessários são expostos em uma matriz que delega valoração ao ambiente analisado. Para objetivar a aplicação dos parâmetros e da matriz de sustentabilidade são escolhidas cinco cidades do estado de Minas Gerais buscando constatar a sustentabilidade do ambiente após a análise de investimentos dos dois programas citado.

Palavras-chave: Planejamento territorial urbano; Política urbana; Desenvolvimento sustentável; Minas Gerais. 


\section{ABSTRACT}

ANDRADE, Elisabete de. Sustainability supported by federal and state urban politics: Governador Valadares, Juiz de Fora, Montes Claros, Poços de Caldas and Uberlândia cases. 2006. 222p. Orientador: Gilda Collet Bruna. FAUUSP, São Paulo.

The present work intends to verify whether public politics would have been able to provide the urban landscape with sustainability. With this purpose, the National Develop Plans issued by the federal government between 1972 and 1985 are analyzed in order to enlighten the urban development proposals contained in each one of them. Among them, the National Program of Half-Sized Cities and the State Program of Intermediary Centers are highlighted and, looking after making a time recovery inside the planning determined by the state government. The world environment debate amplification, after frequent supply deficit, is treated through a review of texts written in World Conferences about Environment and Human Settlements, so it is possible to define criteria that necessarily needs to be contained within an analysis of "urban environment sustainability". A few parameters are defined of what would be advisable to be present in an urban environment which intends to be "sustainable". These parameters qualified as necessary are exposed in a matrix which gives value to the analyzed environment. To aim the parameters application and the sustainable matrix five cities from Minas Gerais are chosen intending to certify the environment sustainability after investments analysis of both programs cited.

Keywords: Urban Territorial Planning, Urban Politics, Sustainable Development, Minas Gerais. 


\section{LISTA DE MAPAS}

Mapa 1 - Fluxos de 1.000 a 5.000 migrantes.

Mapa 2 - Fluxos superiores a 5.000 migrantes.

Mapa 3 - $\quad$ Manchas de recobrimento dos fluxos.

Mapa 4 - Mapa de polarizações

Mapa 5 - Política Nacional de Desenvolvimento Urbano (PNDU), 19751979

Mapa 6 - $\quad$ Tipos de regiões segundo interações espaciais, 1970. .82

Mapa 7 - Situação de Governador Valadares no Estado, distante 324 km de Belo Horizonte.

Mapa 8 - Índice de desenvolvimento humano dos municípios da microrregião de Governador Valadares/MG, 1991.

Mapa 9 - Índice de desenvolvimento humano dos municípios da microrregião de Governador Valadares/MG, 2000.

Mapa 10 - Situação de Juiz de Fora no Estado, distante 278 km de Belo Horizonte.

Mapa 11 - Evolução da malha urbana. Juiz de Fora/MG, 1883-1998.

Mapa 12 - Malha urbana. Juiz de Fora/MG, 1998.

Mapa 13 - Índice de desenvolvimento humano dos municípios da microrregião de Juiz de Fora/MG, 1991.

Mapa 14 - Índice de desenvolvimento humano dos municípios da microrregião de Juiz de Fora/MG, 2000.

Mapa 15 - S Situação do município de Montes Claros/MG no Estado. 
Mapa 16 - Mapa Urbano de Montes Claros/MG, 1970.

Mapa 17 - Mapa Urbano de Montes Claros/MG, 1980

Mapa 18 - Expansão urbana de Montes Claros/MG - 1970-2000.

Mapa 19 - Índice de desenvolvimento humano dos municípios da microrregião de Montes Claros/MG, 1991

Mapa 20 - Índice de desenvolvimento humano dos municípios da microrregião de Montes Claros/MG, 2000.

Mapa 21 - Situação de Poços de Caldas/MG no Estado.

Mapa 22 - Índice de desenvolvimento humano dos municípios da microrregião de Poços de Caldas/MG, 1991

Mapa 23 - Índice de desenvolvimento humano dos municípios da microrregião de Poços de Caldas/MG, 2000

Mapa 24 - Situação do município de Uberlândia/MG no Estado.

Mapa 25 - Índice de desenvolvimento humano dos municípios da microrregião de Uberlândia/MG, 1991

Mapa 26- Índice de desenvolvimento humano dos municípios da microrregião de Uberlândia/MG, 2000 


\section{LISTA DE FIGURAS}

Figura 1 - Vista aérea de Governador Valadares/MG (altitude 5,83 km)...........111

Figura 2 - Vista aérea de Juiz de Fora/MG (altitude 6,36 km) ..........................127

Figura 3- $\quad$ Vista aérea de Montes Claros/MG (altitude 9,99 km)........................140

Figura 4 - Vista aérea de Poços de Caldas/MG (altitude 4,55 km).....................153

Figura 5 - Vista aérea de Uberlândia/MG (altitude 10,05 km)..........................167 


\section{LISTA DE QUADROS}

Quadro 1 - Hierarquia administrativa dos centros urbanos por nível hierárquico e número de funções

Quadro 2 - Grupamentos quanto à infra-estrutura urbana .55

Quadro 3 - Grupamentos quanto às instituições sociais .56

Quadro 4 - Matriz de Indicadores de qualidade de vida urbana .57

Quadro 5 - Matriz de Indicadores de Qualidade de Vida Urbana - Origem dos dados

Quadro 6 - População Urbana no Brasil...... 68

Quadro 7 - Matriz de Qualidade de Vida Urbana .108

Quadro 8 - Microrregião de Governador Valadares/MG

Quadro 9 - Áreas disponíveis no perímetro urbano

Quadro 10 - Matriz de Indicadores de Qualidade de Vida Urbana - Governador Valadares - Matriz com o total dos indicadores

Quadro 11 - Matriz de Indicadores de Qualidade de Vida Urbana - Governador Valadares - $1^{\text {a }}$ ordenação dos dados.

Quadro 12 - Matriz de Indicadores de Qualidade de Vida Urbana - Governador Valadares - composição tonal.

Quadro 13 - Microrregião de Juiz de Fora/MG.

Quadro 14 - Matriz de Indicadores de Qualidade de Vida Urbana - Juiz de Fora - Matriz com o total dos indicadores.

Quadro 15 - Matriz de Indicadores de Qualidade de Vida Urbana - Juiz de Fora - 1 a ordenação dos dados 
Quadro 16 - Matriz de Indicadores de Qualidade de Vida Urbana - Juiz de Fora - composição tonal

Quadro 17 - Matriz de Indicadores de Qualidade de Vida Urbana - Montes Claros - Matriz com o total dos indicadores

Quadro 18 - Matriz de Indicadores de Qualidade de Vida Urbana - Montes Claros - $1^{\underline{a}}$ Ordenação dos dados

Quadro 19 - Matriz de Indicadores de Qualidade de Vida Urbana - Montes Claros - Composição tonal.

Quadro 20 - Matriz de Indicadores de Qualidade de Vida Urbana - Poços de Caldas - Matriz com o total dos indicadores

Quadro 21 - Matriz de Indicadores de Qualidade de Vida Urbana - Poços de Caldas - 1 a ordenação dos dados

Quadro 22 - Matriz de Indicadores de Qualidade de Vida Urbana - Poços de Caldas - Composição tonal.

Quadro 23 - Microrregião de Uberlândia/MG.

Quadro 24 - Matriz de Indicadores de Qualidade de Vida Urbana - Uberlândia Matriz com o total dos indicadores

Quadro 25 - Matriz de Indicadores de Qualidade de Vida Urbana - Uberlândia $1^{\text {a }}$ ordenação dos dados

Quadro 26 - Matriz de Indicadores de Qualidade de Vida Urbana - Uberlândia Composição tonal.

Quadro 27 - Matriz de Indicadores de Qualidade de Vida Urbana - Governador Valadares - Composição tonal

Quadro 28 - Matriz de Indicadores de Qualidade de Vida Urbana - Juiz de Fora 
Quadro 29 - Matriz de Indicadores de Qualidade de Vida Urbana - Montes Claros - Composição tonal

Quadro 30 - Matriz de Indicadores de Qualidade de Vida Urbana - Poços de Caldas - Composição tonal.

Quadro 31 - Matriz de Indicadores de Qualidade de Vida Urbana - Uberlândia Composição tonal

Quadro 32 - Matriz de Indicadores de Qualidade de Vida Urbana - Governador Valadares - Composição tonal

Quadro 33 - Matriz de Indicadores de Qualidade de Vida Urbana - Montes Claros - Composição tonal.

Quadro 34 - Matriz de Indicadores de Qualidade de Vida Urbana - Uberlândia Composição tonal 190

Quadro 35 - Matriz de Indicadores de Qualidade de Vida Urbana - Poços de Caldas - Composição tonal. 190

Quadro 36 - Matriz de Indicadores de Qualidade de Vida Urbana - Juiz de Fora - Composição tonal 190

Quadro 37 - Índice de Gini 194 


\section{LISTA DE TABELAS}

Tabela 1 - Evolução da População residente do município de Governador Valadares/MG - 1970, 1980, 1991, 2000, 2005.

Tabela 2 - Investimentos urbanos em Governador Valadares/MG. Recursos em $\operatorname{Cr} \$ 1.000,00-1980$

Tabela 3 - Investimentos urbanos em Governador Valadares/MG. Recursos em $\mathrm{Cr} \$ 1.000,00-1978 / 1979$ ( $1^{\circ}$ semestre).

Tabela 4 - Investimentos urbanos em Governador Valadares/MG. Recursos em $\operatorname{Cr} \$ 1.000,00$ - 1982

Tabela 5 - Estimativa de disponibilidade de lotes vagos para atendimento à população de Governador Valadares/MG.

Tabela 6 - Investimentos urbanos por fonte em Juiz de Fora/MG. Recursos em Cr\$1.000,00 - 1978/1979 ( $1^{\circ}$ semestre).

Tabela 7 - População do município de Juiz de Fora/MG por ocasião dos Censos Demográficos de 1950 a 1991.

Tabela 8 - Investimentos urbanos por fonte em Montes Claros/MG. Recursos em Cr\$1.000,00 - 1978/1979 (1ํ semestre).

Tabela 9 - Microrregião de Poços de Caldas/MG.

Tabela 10 - Investimentos urbanos em Poços de Caldas/MG. Recursos em Cr\$1.000,00 - 1980 .

Tabela 11 - Investimentos urbanos em Poços de Caldas/MG. Recursos em Cr\$1.000,00 - 1982 .

Tabela 12 - Investimentos urbanos por fonte em Uberlândia/MG. Recursos em Cr\$1.000,00 - 1978/1979 (1으 semestre). 
Tabela 13 - Investimentos urbanos por fonte em Uberlândia/MG. Recursos em $\mathrm{CR} \$ 1.000,00-1982$. 


\section{LISTA DE SIGLAS}

BDMG Banco de Desenvolvimento de Minas Gerais

BID Banco Interamericano de Desenvolvimento

BIRD Banco Internacional de Reconstrução e Desenvolvimento

BNH Banco Nacional de Habitação

CEASA Centrais de Abastecimento de Minas Gerais S/A

CMMAD Comissão Mundial sobre Meio Ambiente e Desenvolvimento

CNDU Conselho Nacional de Desenvolvimento Urbano

CNPU Comissão Nacional de Regiões Metropolitanas e Políticas Urbanas

COHAB/MG Companhia de Habitação do Estado de Minas Gerais

CPM/BIRD Cidade Porte Médio/Banco Internacional de Reconstrução e Desenvolvimento

Cr\$ cruzeiros

CURA Comunidade Urbana para Renovação Acelerada

DER Departamento de Estradas de Rodagem

DNOS Departamento Nacional de Obras de Saneamento

ECO-92 Conferência das Nações Unidas para o Meio Ambiente e o Desenvolvimento

EIA Estudos de Impacto do Meio Ambiente

EMBRAPA Empresa Brasileira de Pesquisa Agropecuária

ETE Estação de Tratamento de Esgotos

FAUUSP $\quad$ Faculdade de Arquitetura e Urbanismo da Universidade de São Paulo 
FDTU Fundo de Desenvolvimento dos Transportes Urbanos

FJP Fundação João Pinheiro

FNDU Fundo Nacional de Desenvolvimento Urbano

FNTU Fundo Nacional de Transporte Urbano

ha hectare

hab/ha habitants por hectare

Habitat I I Conferência das Nações Unidas sobre Assentamentos Humanos

Habitat II II Conferência das Nações Unidas sobre os Assentamentos Humanos

I PND I Plano Nacional de Desenvolvimento

IBGE Fundação Instituto Brasileiro de Geografia e Estatística

IDH Índice de Desenvolvimento Humano

IDH-Municipal Índice de Desenvolvimento Humano Municipal

IGA Instituto de Geociência Aplicada

II PND II Plano Nacional de Desenvolvimento

III PND III Plano Nacional de Desenvolvimento

IPEA Instituto de Pesquisas Econômicas Aplicadas

IQVU Índice de Qualidade de Vida Urbana

IULCLG Imposto Único sobre Lubrificantes e Combustíveis Líquidos e

Gasosos

$\mathrm{km}^{2} \quad$ quilômetro quadrado

MG Minas Gerais

ONU Organização das Nações Unidas

PAITT Plano de Ação Imediata de Transporte e Trânsito

PASEP Programa de Formação do Patrimônio do Servidor Público 
PBH Prefeitura Municipal de Belo Horizonte

PDDU Plano Diretor de Desenvolvimento Urbano

PDLI Programa de Desenvolvimento Local Integrado

PEA População Economicamente Ativa

PECON Programas Estaduais de Controle da Poluição

PIB Produto Interno Bruto

PIS Programas de Integração Social

PLAMBEL Planejamento Metropolitano de Belo Horizonte

PLANASA Plano Nacional de Saneamento

PMGV Prefeitura Municipal de Governador Valadares

PNCCPM Programa Nacional de Capitais e Cidades de Porte Médio

PNDs Planos Nacionais de Desenvolvimento

PNDU Política Nacional de Desenvolvimento Urbano

PNUD Programa das Nações Unidas para o Desenvolvimento

PROECI Programa Estadual de Centros Intermediários

Projeto CURA Projeto Consumo e Uso Racional da Água

PRO-RURAL Programa de Assistência ao Trabalhador Rural.

PUC Minas Pontifícia Universidade Católica de Minas Gerais

$\mathrm{R} \$ \quad$ reais

RIMA Relatórios de Impacto do Meio Ambiente

RMBH Região Metropolitana de Belo Horizonte

ROLAC Escritório Regional para América Latina e Caribe do UN-Habitat (UN-Habitat's Regional Office for Latin America and the Caribbean)

$\mathrm{RUH} \quad$ regiões urbanas homogêneas

SAAE Serviço Autônomo de Água e Esgoto 
SAGMACS Sociedade de Análises Gráficas e Mecanográficas Aplicadas aos Complexos Sociais

SEAPA/MG Secretaria de Estado de Agricultura, Pecuária e Abastecimento

SEMA Secretaria Especial do Meio Ambiente

SEMOV Serviço Municipal de Obras e Viação

SERFHAU Serviço Federal de Habitação e Urbanismo

SES/MG Secretaria de Estado de Saúde de Minas Gerais

SETAS/MG Secretaria de Estado do Trabalho e Ação Social

SIDRA Sistema IBGE de Recuperação Automática

SUDAM Superintendência do Desenvolvimento da Amazônia

SUDECO Superintendência do Desenvolvimento do Centro-Oeste

SUDENE Superintendência de Desenvolvimento do Nordeste

SUDESUL Superintendência do Desenvolvimento do Sul

UNEP Programa das Nações Unidas para Desenvolvimento (United

Nations Environment Program)

UN-Habitat Programa das Nações Unidas para os Assentamentos Humanos

(United Nations Human Settlements Programme)

VTI Valor da Transformação Industrial

ZEIS Zonas Especiais de Interesse Social 


\section{SUMÁRIO}

1 INTRODUÇÃO

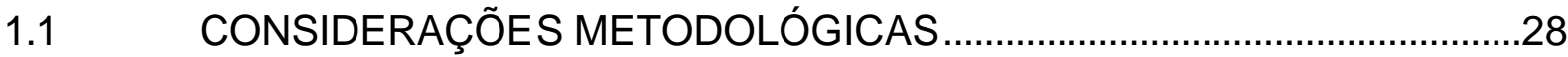

1.2 DETERMINAÇÃO DO OBJETO DE ESTUDO ………………………........29

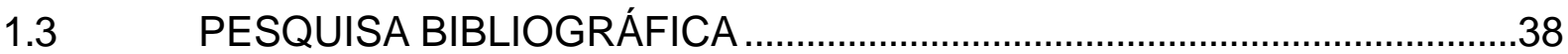

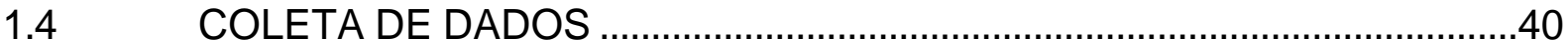

1.4.1. Indicadores de sustentabilidade urbana ....................................................

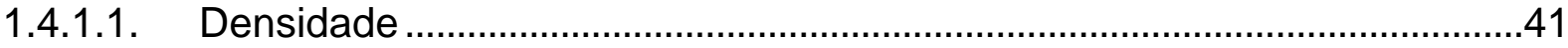

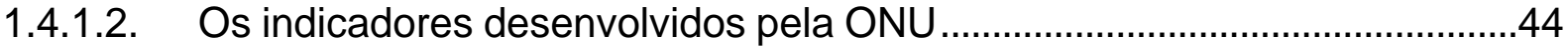

1.4.1.3. Outros indicadores.................................................................................

1.4.2. Proposta de Matriz de Sustentabilidade.....................................................52

1.4.2.1. Matriz de Sustentabilidade ......................................................................53

1.4.2.2. Matriz de sustentabilidade - primeiras alterações ......................................54

1.4.3. Análise da matriz resultante de Qualidade do Ambiente Urbano ................58

1.4.4. Matriz de Indicadores de Qualidade de Vida Urbana - origem dos

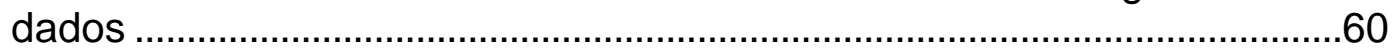

1.4.5. Matriz de Indicadores de Qualidade de Vida Urbana - Matriz Tonal..........63

1.5 DESENVOLVIMENTO DO TRABALHO ………………….........................

2 POLÍTICAS PÚBLICAS E DESENVOLVIMENTO …...................................66

2.1 O crescimento da população brasileira …………………………………......67

2.2 A política urbana do Regime Centralizador ....................................................69

2.3 O Programa Nacional de Cidades Médias......................................................85

2.4 Programa Estadual de Centros Intermediários (PROECI) …………............86

3 SUSTENTABILIDADE URBANA: CONCEITUAÇÃO E

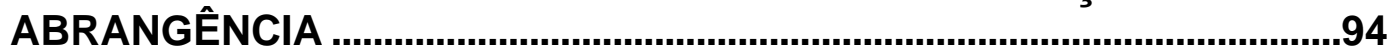

3.1 SUSTENTABILIDADE - EVOLUÇÃO CONCEITUAL …………………......96

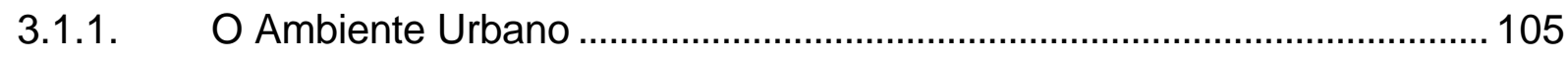

3.2 CONSIDERAÇÕES FINAIS ………………..................................... 108

4 ESTUDO DE CASO: O EFEITO DAS POLÍTICAS PÚBLICAS NOS MUNICÍPIOS.. 


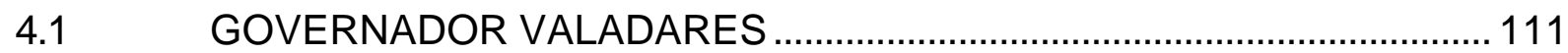

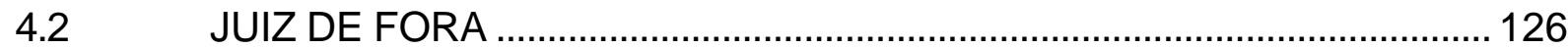

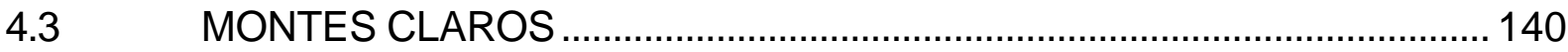

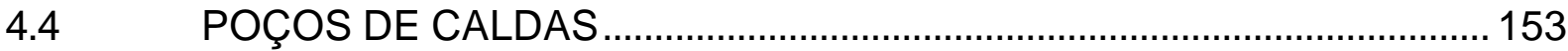

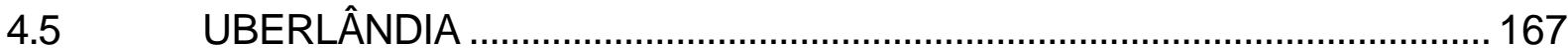

4.6 O APARATO URBANÍSTICO BRASILEIRO .......................................... 177

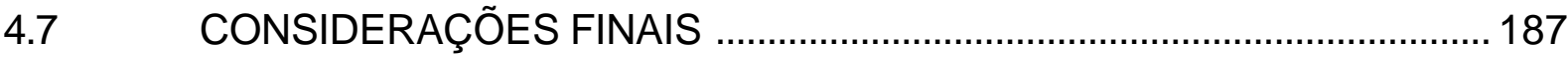

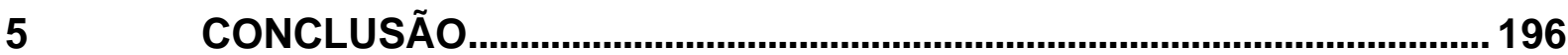

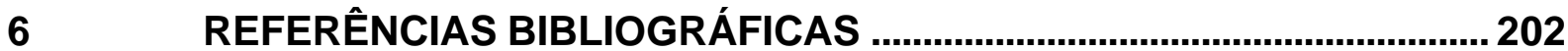

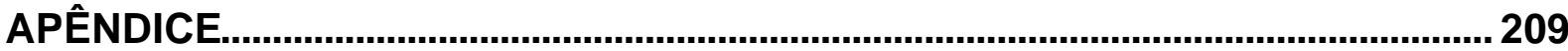

ANEXOS 210 
1 INTRODUÇÃO 
eguramente é no século vinte que são promovidas grandes batalhas da revolução urbana. A ampliação da sociedade urbana ocorre em grande escala e comanda o aumento da população humana.

O mundo todo é tomado de assalto pelos significativos incrementos populacionais, resultantes de melhoras tecnológicas tanto nas áreas médicas, quanto no setor da alimentação.

E este crescimento tem como conseqüência uma ampliação na pressão sobre os recursos existentes, necessários à sobrevivência dessa população em crescente aumento.

Advertências quanto ao crescimento da população frente à manutenção de recursos definidos, começam a ter lugar nos anos 1950. No início dos anos de 1970, quando começam a ocorrer as primeiras crises advindas da diminuição da produção de petróleo no Oriente Médio - o Choque do Petróleo, alguns analistas apontaram para a necessidade de contenção das taxas de natalidade, prioritariamente as taxas de crescimento dos países pobres, que seriam maiores que as dos países de primeiro mundo.

O grande confronto mundial que emergia ou apontava para uma possível emergência, era o da escassez, em todos os seus matizes. A permanência da espécie humana estava ameaçada frente a um eminente colapso dado pelo superpovoamento

Para além da questão populacional, a questão ambiental colocava em cheque o crescimento econômico frente à exploração de recursos finitos, que não poderiam ser garantidos para as futuras gerações de habitantes.

Surge o paradigma da 'sustentabilidade' como sendo a possibilidade de continuidade do desenvolvimento econômico, baseado sobretudo no desenvolvimento social. A correta utilização dos recursos esgotáveis daria à questão 
ambiental o ponto de inflexão necessário para sua equação, o que determinava a necessidade do estabelecimento de diretrizes norteadoras para um novo tipo de desenvolvimento que não ameaçasse tanto o planeta.

Concomitantemente ao processo de discussão ambiental no mundo, o regime político brasileiro estava se endurecendo. A partir de 1964 instala-se no país um regime ditatorial, com o golpe militar. A organização e expressão políticas da sociedade são cerceadas paulatinamente.

No quadro de um país com reduzida participação política, surgem os planos centralizados de desenvolvimento econômico e social, bastante afinados com os novos direcionamentos da economia mundial. Os planos destinam-se a todos os setores de importância social, com políticas setoriais desenvolvidas para cada qual sem uma clara vinculação entre elas. Surgem a partir daí, os textos dos Planos Nacionais de Desenvolvimento.

Os PNDs tentam abranger uma totalidade de questões, tornando-se por vezes, demasiadamente vagos sobre a forma com a qual pretendiam enfrentar os problemas levantados através das políticas setoriais sugeridas, tais como a política da habitação, do saneamento, do urbano.

De toda forma, as questões relativas ao desenvolvimento urbano são contempladas então como pertinentes ao planejamento nacional, tendo o reconhecimento da questão urbana em âmbito nacional.

Assim sendo, o avanço das questões pertinentes ao ambiente urbano e impulsionado pela necessidade de criação de políticas redistributivas de desenvolvimento econômico e social, o Governo Federal cria os Planos Nacionais de Desenvolvimento. Para efeitos deste trabalho, serão analisados três planos nacionais de desenvolvimento. 
O I Plano Nacional de Desenvolvimento (I PND) data de 1972-1974, foi desenvolvido durante o governo do presidente militar Emílio Garrastazu Médici e sua proposição sobre políticas urbanas está subentendida ao longo dos textos que contemplam o crescimento favorecendo uma desconcentração econômica do Sudeste.

O II Plano Nacional de Desenvolvimento (II PND) contempla um capítulo que se intitula: "Desenvolvimento urbano. Controle da poluição e preservação do meio ambiente". Neste capítulo, de número IX no conjunto da obra, é determinada uma política de desenvolvimento urbano, explicitada pelo 'Programa de Ação do Governo na Área do Desenvolvimento Urbano', que œntempla as diversas macro-regiões do país, apontando áreas de contenção, controle e dinamização no território nacional.

Nesta época é proposto o Programa Nacional de Capitais e Cidades de Porte Médio (PNCCPM), que firmará convênios com municípios visando promover dinamização de diversos setores da estrutura urbana nacional. Sua atuação será analisada neste trabalho em busca da verificação a cerca da eficácia ${ }^{1}$ das políticas públicas no desenvolvimento da qualidade do meio ambiente urbano.

O III Plano Nacional de Desenvolvimento (III PND), 1980-1985, não instaura grandes diferenças em relações à abordagem setorial das questões urbanas, dando ênfase e destaque ao Saneamento, Habitação, Educação e outros setores, tal como já havia sido privilegiado no I PND, mas enfatiza a abordagem sobre a questão ambiental ao trazer um capítulo sobre meio ambiente, que seria precursor da Política Nacional de Meio Ambiente.

Para fins deste trabalho, no que diz respeito ao estado de Minas Gerais aborda-se o programa proposto pelo Governo Estadual, contemporâneo aos PNDs

1 Segundo Serra (1991), "Nessas avaliações, em geral entende-se eficiência como a capacidade de cumprir orçamentos e cronogramas físico-financeiros; eficácia seria a qualidade de atingir os objetivos gerais do programa". (SERRA, 1991, p. 78). 
do Governo Federal. Ressalta-se que o governo do estado procurou estabelecer políticas urbanas e regionais, não apenas de desconcentração e sim de desenvolvimento de potencialidades hierárquicas, através de uma tentativa de reorganização da rede urbana existente.

Assim, o Programa Estadual de Centros Intermediários (PROECI) é também foco da análise, como o PNCCPM, na eficácia de promoção do ambiente das cidades, tendo sido elaborado pelo Governo do Estado de Minas Gerais, nos anos de 1980. Seus principais objetivos eram: desenvolver a integração das diversas regiões do estado e com outros estados, permitindo um desenvolvimento mais homogêneo de todas elas e dinamizar pólos regionais, criando uma estrutura mais equilibrada de lugares centrais. (FJP, 1980a, p. 3).

Todos estes planos e programas são contemporâneos e aqui procura-se evidenciar efetivamente - eficiente e eficazmente, alteraram o funcionamento do espaço urbano das cidades envolvidas, dotando-as de novas características e melhorando a qualidade ambiental ao ampliar o acesso da população a infraestrutura e a equipamentos comunitários. E, para o caso do PROECl, se estas medidas conseguem dinamizar efetivamente dinamizar o planejamento urbano e regional do estado através da reafirmação dos pontos da rede de cidades mineiras, como pretendia.

Assim sendo, o encaminhamento do plano de pesquisa desta tese seguiu duas orientações básicas:

- A exposição da questão urbana como um problema de ordem ambiental, que proporciona o desenvolvimento do conceito 'sustentabilidade' urbana;

- Analisar de planos, programas e políticas urbanas ocorridas durante os anos 1970/1980 e o resultado de suas ações na consolidação de um ambiente 
urbano cujas características estejam pertinentes aos atributos aqui apresentados como necessários à sustentabilidade urbana.

Para que tal objetivo seja possível, fez-se necessária a escolha de cidades que fossem sido alvo destas políticas. Foram então, determinadas cinco cidades no estado de Minas Gerais.

\subsection{CONSIDERAÇÕES METODOLÓGICAS}

A hipótese colocada neste trabalho é que houve eficiência das políticas urbanas no desenvolvimento de um ambiente sustentável. Para lograr este objetivo a metodologia do trabalho foi assim caracterizada:

- $\quad$ Levantamento e análise bibliográfica;

- $\quad$ Busca e estudo dos textos das conferências internacionais promovidas pela Organização das Nações Unidas (ONU) sobre meio ambiente e cidade para o estabelecimento da evolução do termo 'sustentabilidade' e para a aplicação do mesmo sobre o ambiente urbano;

- Reagrupamento de indicadores para composição de matriz conceitual sobre qualidade do ambiente urbano;

- $\quad$ Análise das políticas urbanas do período dos governos centralizadores no Brasil e em Minas Gerais;

- $\quad$ Estudo de caso de cinco cidades, adotando os indicadores determinados na matriz conceitual de qualidade do ambiente urbano para análise de sua qualidade ambiental;

- $\quad$ Conclusões. 


\subsection{DETERMINAÇÃO DO OBJETO DE ESTUDO}

O objeto de estudo deste trabalho volta-se para análise de critérios pertinentes à constituição de uma ambiência urbana sustentável que possa ser mensurada através de dados coletados.

Neste sentido, parte-se da análise da realidade local conhecida, no caso, o estado de Minas Gerais, para através dela determinar o objeto de estudo. $\mathrm{Na}$ evolução dos estudos sobre planejamento regional percebe-se uma forte potencialização dos demais estados sobre regiões mineiras, fragmentando o estado de Minas Gerais.

A rede urbana é, de forma geral, constituída por um sistema de cidades que possuem tamanhos e hierarquias distintas. Uma cidade de porte maior acumula uma série de serviços - sejam eles privados ou estatais - que só se viabilizam pela presença daquele tamanho de população ali existente. Esta cidade tende a ser o nó do sistema de cidades de uma região, estado ou país. Sendo articulada pelas linhas de ligação com outras localidades, esta sua centralidade tende a ser reafirmada, pois de vários pontos do território tem-se acesso a este nó. Isto faz com que sua potencialidade de exercício de funções torne-se acentuada e que este centro urbano passe a ter uma hierarquia superior em nível de serviços (IPEA, IBGE, UNICAMP, 2001).

Então, os nós são pontos focais do sistema urbano, os quais atraem os investimentos, pois pela sua locação neste ponto, podem ser mais facilmente acessados por outros pontos do sistema.

Para fins de planejamento, são feitas regionalizações respeitando as articulações em rede, ou as relações entre as diversas cidades de uma mesma região. Tal compartimentação espacial objetiva a locação de recurso de forma 
eficiente nos pontos de hierarquia superior. Por este motivo, as redes ou o estudo da rede urbana faz-se necessário para que possam ocorrer determinações do planejamento, uma vez que este, visa otimizar os recursos escassos (CINTRA; HADDAD, 1977).

Para alguns autores (CASTELLS, 1989) a flexibilização das interrelações proporcionada pela globalização, com o advento das 'redes informacionais' passa a ter liderança tornando secundária em importância a rede física, representada pela presença de elementos físicos de ligação entre as cidades.

Porém, estas últimas não sucumbem a existência das primeiras, pois sempre haverá a necessidade do meio físico para que possam ocorrer as trocas.

Matos (2005) também referenda a existência física da rede como necessária ao desenvolvimento do processo econômico:

A rede de localidades urbanas, reduzida a seus mais importantes nódulos, é uma expressão de espaços geográficos consolidados e emergentes do Brasil contemporâneo, por onde certamente irão convergir os principais esforços de retomada do desenvolvimento econômico. As articulações são canais privilegiados de ligação, estruturas físicas-chave sob as quais se definem outras estruturas, algumas delas intangíveis, mas estratégicas, porque carregadas de informações, culturas e representações políticas e sociais, a exemplo das infovias. Por elas superpõe-se objetos, investimentos, múltiplas territorialidades e tendências que a globalização sinaliza. (MATOS, 2005, p. 51).

O autor utiliza os seguintes mapas para exemplificar que, através dos pontos de saída e chegada das migrações, pontos táteis da rede de cidades, configuram-se os fluxos mais pertinentes à sociedade urbana.

Pela análise tanto dos fluxos quanto dos recobrimentos dos mesmos fica evidente a concentração da rede de cidades brasileiras na porção leste do país, propiciada pela existência da costa, por onde serão estabelecidas as principais relações comerciais. A interiorização da rede será propiciada também por estas 
relações, na medida em que forem sendo incorporados novos recursos naturais e produtos a este comércio.

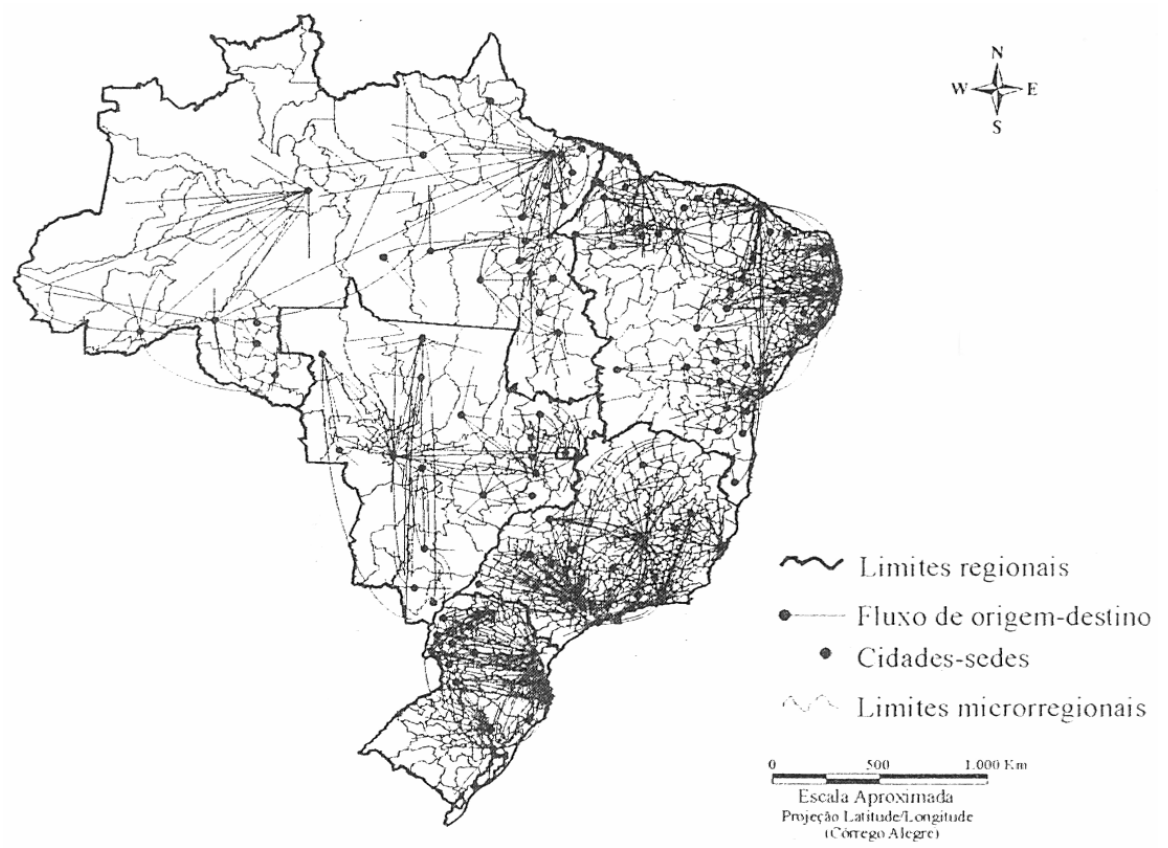

\section{Mapa 1 - $\quad$ Fluxos de 1.000 a 5.000 migrantes.}

FONTE: Matos, 2005.

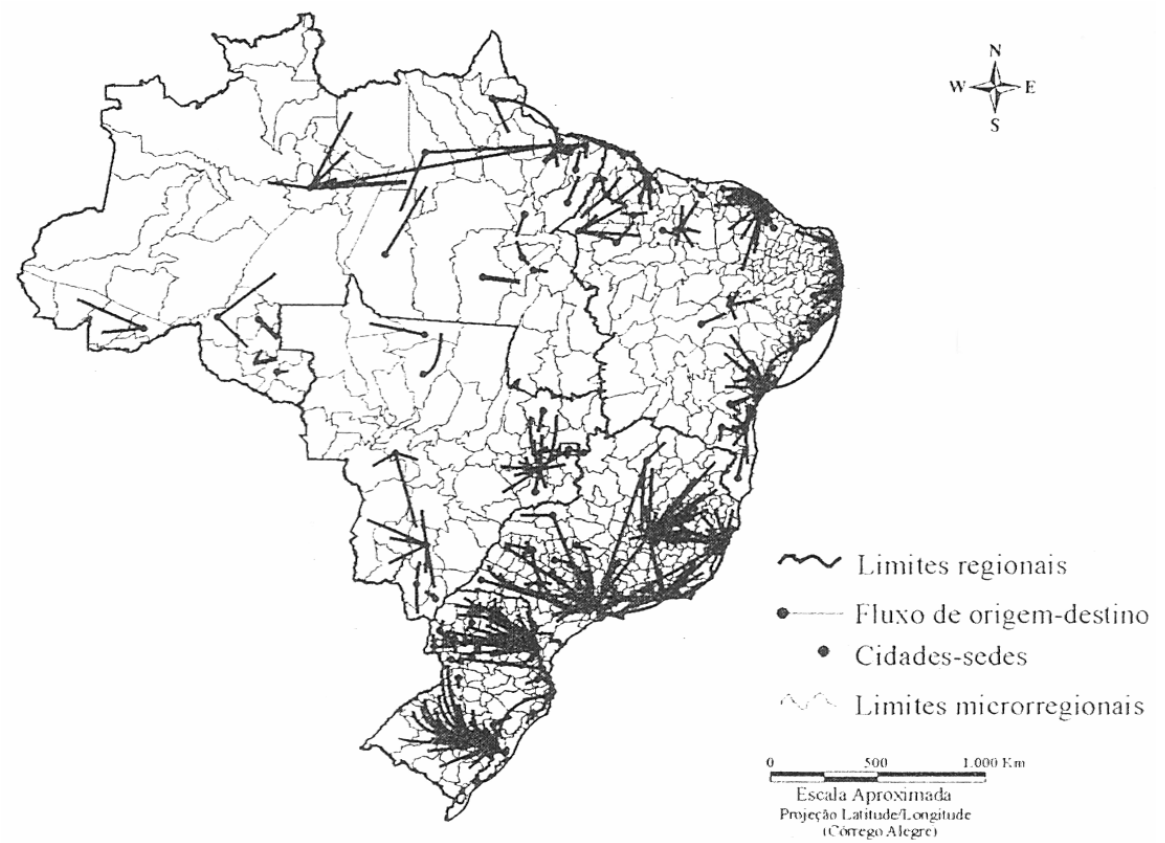

Mapa 2 - $\quad$ Fluxos superiores a 5.000 migrantes.

FONTE: Matos, 2005. 


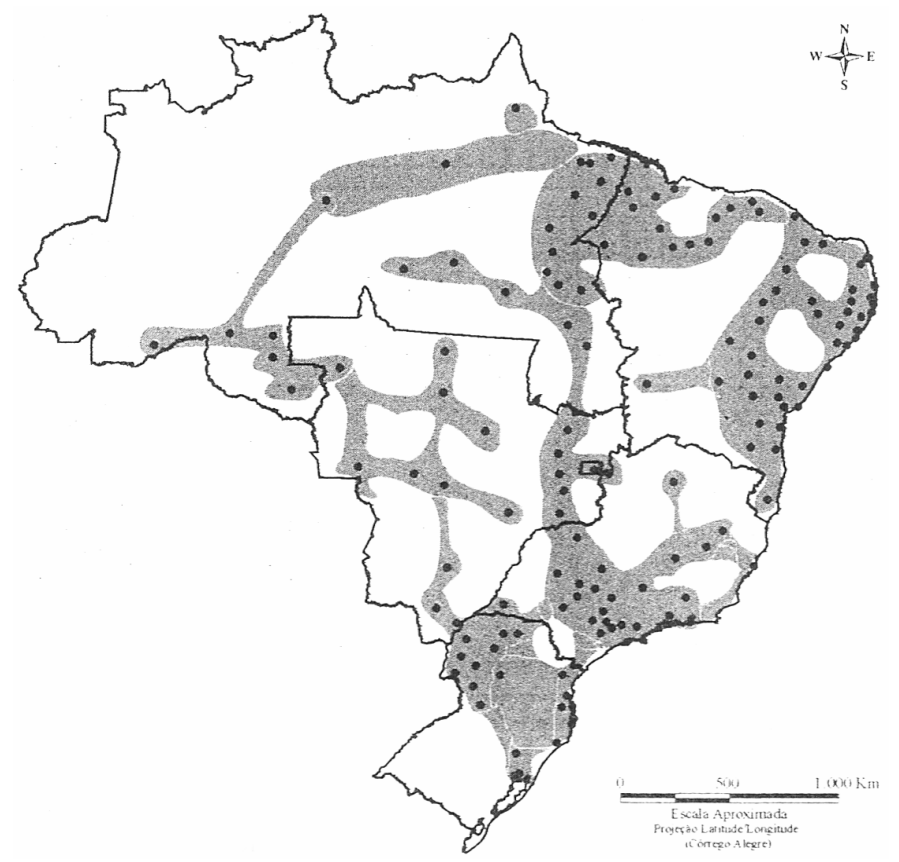

\section{Mapa 3 - $\quad$ Manchas de recobrimento dos fluxos.}

FONTE: Matos, 2005.

Os mapas 1, 2 e 3 mostram fluxos estabelecidos entre as cidades que podem ser constatados pelos dados dos Censos, de origem e destino dos fuxos migratórios, trocas que são estabelecidas fisicamente.

No sentido de fortalecimento do sistema urbano do estado, foi encaminhada a escolha do objeto de estudo.

Partiu-se então, para um reconhecimento do sistema urbano do estado, seus principais pontos na hierarquia urbana, as tensões exercidas por eles no restante do território e as polarizações que outros estados viessem a exercer estas regiões.

Assim, a análise de Andrade e Monte-Mór (1983), foi utilizada neste trabalho. Para eles, o espaço polarizado por Belo Horizonte constitui o efetivo espaço integrado mineiro. Esta afirmação conduz a duas análises. A primeira delas diz respeito ao fato de ser neste espaço local que ocorre a maior divisão territorial de trabalho, com uma maior integração entre cidades, tendo, portanto, maior possibilidade de constituição de uma rede de cidades equilibrada. Ao mesmo tempo, 
a concentração de infra-estrutura e investimentos que potencializa, a área reforça o desequilíbrio do restante do estado.

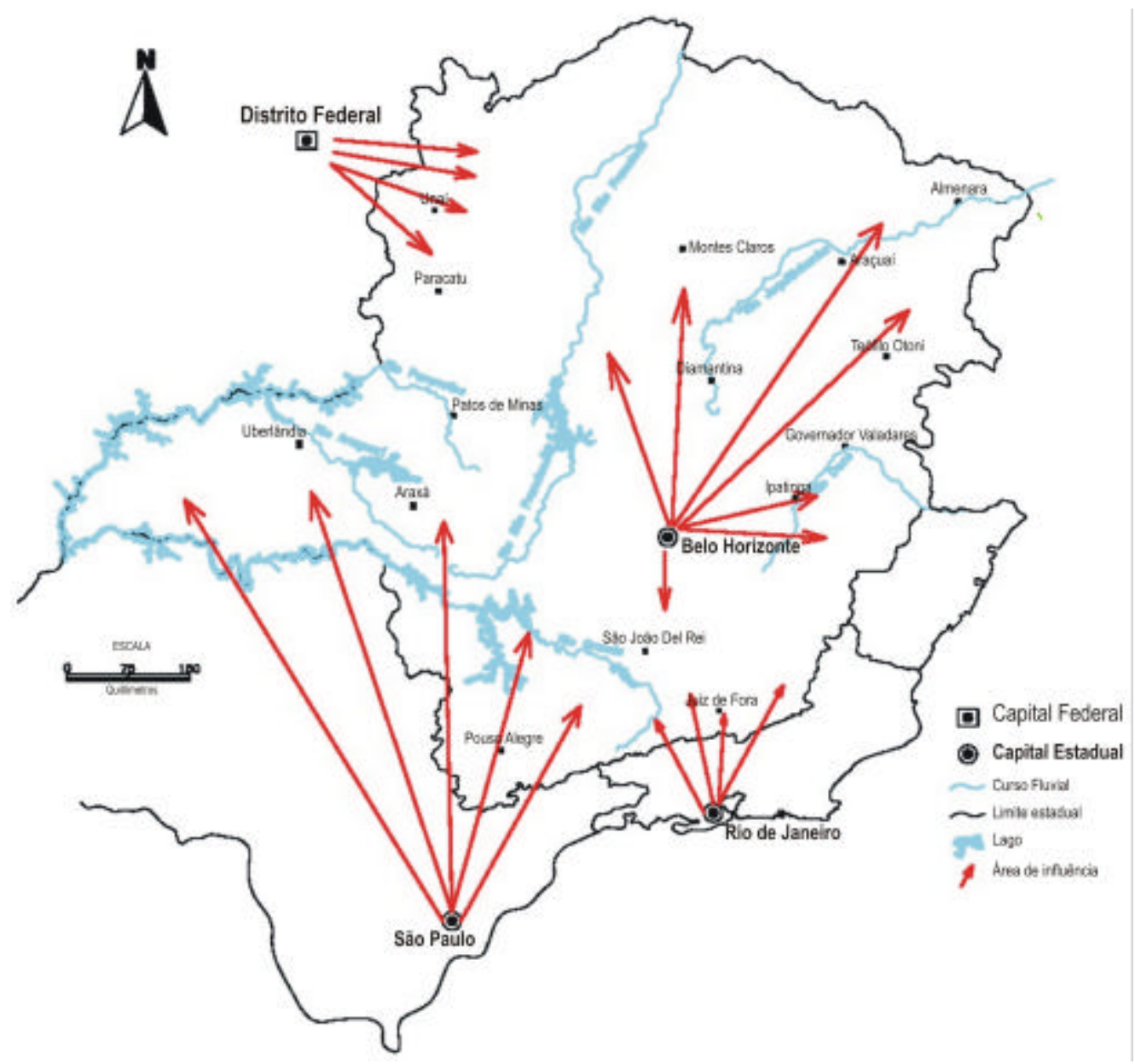

\section{Mapa 4 - Mapa de polarizações}

AUTORIA: ANDRADE, Elisabete.

FONTE: ANDRADE; MONTE-MÓR, 1983.

Nesta análise, os autores enfatizam a fragmentação da rede de cidades mineiras reforçada no período do planejamento centralizador. Ressaltam a desigualdade do espaço mineiro e as diversas "Minas" que foram assim constituídas, ao contrário da tão ansiada unificação do estado.

A fragmentação a que se referem pode ser acompanhada na ilustração do Mapa de Polarizações. Segundo os autores, Minas Gerais estaria sempre sendo polarizada por outras economias, tais como a de São Paulo ou o Rio de Janeiro. 
Esta polarização faria com que nunca se conseguisse uma coesão espacial

para Minas, fazendo com que o estado tivesse sempre muitas referências externas a

capital, que nunca conseguiria a unificação de uma única "Minas".

No trecho que se segue, foi reproduzida uma caracterização da estrutura urbana do estado de Minas Gerais:

Neste ponto é desejável uma rápida visão da macro-estrutura espacial do estado, com uma breve descrição das grandes regiões que 0 integram. Considerando as diversas regionalizações do estudo, o espaço mineiro pode ser descrito segundo grandes espaços de polarização - o espaço de influência direta de Belo Horizonte, que já então se estendia até o Norte, nos limites com a Bahia; o espaço de influência direta do Rio de Janeiro; os espaços de influência e polarização imediata de São Paulo e um sub-espaço regional a noroeste, de crescente polarização para Brasília. Pode-se dizer, talvez, que o espaço polarizado por Belo Horizonte constitui o efetivo espaço integrado mineiro, e comporta uma divisão em duas realidades distintas:

A Região Metalúrgica, área central de concentração das antigas minas de ouro, agora dominada pela economia do ferro, carro chefe da industrialização mineira e do próprio crescimento e desenvolvimento econômico do estado. Aí se concentram os esforços e esperanças dos mineiros no sentido de restaurar as condições de riqueza e abundância que marcaram seu nascimento. Em 1970, a região Metalúrgica já concentra $26 \%$ da população total do estado, e $38,9 \%$ da população urbana, sendo responsável por $50,3 \%$ do PIB estadual e por $68,35 \%$ do VTI. Além de Belo Horizonte e algumas cidades de sua Região Metropolitana, destacam-se o aglomerado Urbano do Vale do Aço, alguns centros médios monoindustriais (Monlevade, Itabira) e cidades médias outras que cresceram com a indústria de bens intermediários e de capital, como Lafaiete, Divinópolis, Sete Lagoas, Itaúna, entre outros. Com os mais altos índices de densidade e qualidade do sistema de transporte, e dotada de infra-estrutura de apoio à produção bastante desenvolvida, a região metalúrgica se impõe completamente como o espaço principal da economia mineira;

As regiões pobres do Norte do Estado, polarizadas por Belo Horizonte, quais sejam, a região do Alto São Francisco, a região do Noroeste de Minas, a região do Jequitinhonha e a região do Rio Doce. O Alto São Francisco, a oeste de Belo Horizonte, é a antiga região de entrada para o sertão, onde se desenvolveu no século passado parte da industrialização incipiente que descrevemos em breves linhas. Já apresentava um processo de urbanização antigo e próximo da média estadual, marcada esta pelas regiões mais antigas. Suas vinculações econômicas com o espaço central do estado e com o triângulo Mineiro lhe garantiram um crescimento superior à média estadual e sua localização intersticial lhe permitiu se beneficiar de uma rede rodo-ferroviária já previamente implantada. Entretanto, participa no VTI estadual com apenas 2,01\% em 1970 e apresenta uma posição relativa na estrutura percentual da população 
total e urbana do estado declinante desde 1950. (ANDRADE; MONTE-MÓR, 1983, p. 9-10).

Assim sendo, o Noroeste de Minas é uma região tipicamente de pecuária extensiva, agricultura em modernização e incipiente indústria tradicional, com baixa urbanização. Montes Claros domina o sistema regional, tendo Pirapora como principal sub-centro regional. Alguns centros médios, como Paracatu e Unaí, tiveram seu crescimento influenciado pela proximidade com Brasília, o que possibilita outro fator de desagregação do estado. Na década de 60 , esta região foi incluída na área de atuação da Superintendência de Desenvolvimento do Nordeste (SUDENE), em esforços para assegurar a atração de projetos industriais de peso, numa tentativa de aumentar sua população total e urbana pela fixação.

O Vale do Jequitinhonha é uma área baseada na pecuária de corte extensiva. Possui uma economia extremamente frágil e desarticulada, um sistema de transportes precário e uma rede urbana reduzida a numerosos povoados de caráter rural. Destacam-se algumas cidades de maior economia do período minerador, como Diamantina e Serro e alguns lugares centrais ao Norte, como Araçuaíe Almenara.

A região do Rio Doce, a nordeste, é relativamente polarizada pelo Rio de Janeiro, sendo também ligada à região central, em parte devido ao crescimento da indústria siderúrgica do Alto Rio Doce - Vale do Aço. É uma região de intenso crescimento desde os anos 1940, com atividades de abastecimento do sul do país agricultura e pecuária, bem como uma indústria tradicional e uma agroindústria nascente. Tem como centros significantes, Governador Valadares e Teófilo Otoni.

A Zona da Mata é uma região polarizada pelo Rio de Janeiro, tendo Juiz de Fora como principal cidade da região, incapaz de articular internamente o espaço regional. Área de minifúndios apresentava as melhores condições de transporte e 
infra-estrutura urbana do estado até a década de 50 , resultante do período do café e da industrial tradicional que ali aconteceu em épocas anteriores. A estagnação econômica, no entanto, transformou-a em uma região expulsora de mão-de-obra.

O Sul de Minas e o Triângulo Mineiro são potencialmente polarizados por São Paulo. O Sul possui muitas cidades pequenas bem equipadas articuladas a centros médios e à própria São Paulo, mas tem perdido população, como será analisado no capítulo sobre estudo de caso. Possui taxas de crescimento e urbanização inferiores às médias do estado. Os dados mostram que estão perdendo população como mostram os dados

Já o Triângulo Mineiro possui algumas cidades médias que atendem a um espaço dinamizado pela economia ligada principalmente a pecuária. Suas taxas de crescimento e urbanização são superiores a do estado e constitui uma região atrativa de mão-de-obra, muito devido à sua posição estratégica em relação à ocupação do Centro-Oeste e da Amazônia. Uberaba e Uberlândia se consolidam como pólos regionais e algumas cidades médias se fortalecem, como Araguari, Ituiutaba e Araxá. É uma economia dinâmica, com relativa autonomia face ao estado de Minas Gerais e tem gerado excedentes econômicos suficientes a construção de um espaço regional e urbano mais integrado e equilibrado, com a presença de funções urbanas bem distribuídas.

Por isso procura-se abordar uma cidade pólo de cada uma destas regiões, com exceção da região do Vale do Jequitinhonha, por constituir um espaço polarizado por Belo Horizonte, cujas cidades médias possuem reduzida expressão no panorama do estado. Esta divisão tem por intuito caracterizar a qualidade de vida gerada pelas ações do estado sendo capazes de atenuar ou potencializar as diferenças regionais. Foram definidas as seguintes cidades para o estudo de caso, representantes das cinco regiões anteriormente determinadas: 
- $\quad$ Noroeste - Montes Claros;

- Rio Doce - Governador Valadares;

- $\quad$ Sul de Minas - Poços de Caldas;

- $\quad$ Zona da Mata - Juiz de Fora;

- $\quad$ Triângulo Mineiro - Uberlândia.

No que se refere à contemporaneidade desta divisão regional, decorridos vinte anos da compartimentação feita por Andrade e Monte-Mór, ainda que tenham surgido esta pode-se dizer que tenha ocorrido mudanças de tamanhos das cidade mas que sua escolha continua pertinente a uma análise atual, por permanecer a mesma hierarquia dentro do estado.

Também a Fundação João Pinheiro (FJP) apresenta a hierarquização da estrutura urbana do estado, feitas, em $1982^{2}$, sendo as duas utilizadas como recorte teórico na determinação das cinco cidades que são objeto de análise deste trabalho.

Segundo a FJP (1982) era assim distribuída a hierarquia administrativa do estado de Minas Gerais naquele período:

Quadro 1 - Hierarquia administrativa dos centros urbanos por nível hierárquico e número de funções

\begin{tabular}{|l|c|c|c|}
\hline Nível hierárquico & Número & Centro Urbano & Número total de funções administrativas \\
\hline $1^{0}$ & 1 & Belo Horizonte & 112 \\
\hline \multirow{2}{*}{$2^{\circ}$} & 1 & Governador Valadares & 63 \\
\cline { 2 - 4 } & 2 & Montes Claros & 62 \\
\hline \multirow{2}{*}{$3^{\circ}$} & 1 & Juiz de Fora & 58 \\
\hline $5^{0}$ & 2 & Uberlândia & 57 \\
\hline
\end{tabular}

FONTE: FJP, 1982.

Como pode ser observado no quadro acima, a escolha dos estudos de caso seguiu a ordem de importância hierárquica das cidades mineiras, no último estudo dedicado ao assunto feito no estado de Minas Gerais. Note-se que foram escolhidas as quatro primeiras cidades médias mineiras em funções administrativas. A escolha

\footnotetext{
2 FJP. Fundação João Pinheiro. Estrutura Espacial de Minas Gerais. Belo Horizonte: FJP, 1982.
} 
de Poços de Caldas se deu devido a dois motivos: primeiro, não havia, situada entre as primeiras cidades da hierarquia apresentada pelo trabalho da FJP, nenhuma cidade que fosse da Zona da Mata, caracterizada no texto acima como área de influência da cidade do Rio de Janeiro. Mas ainda, segundo a classificação feita pelo Programa das Nações Unidas para o Desenvolvimento (PNUD), juntamente com a FJP, de acordo com o Índice de Desenvolvimento Humano Municipal (IDHMunicipal), a cidade de Poços de Caldas é a primeira em IDH-Municipal no Estado de Minas Gerais.

Será bastante útil, portanto, tê-la como referência para análise das demais cidades, uma vez que o estudo busca a definição de parâmetros que devam ser observados para composição do ambiente urbano de características sustentáveis.

\subsection{PESQUISA BIBLIOGRÁFICA}

A bibliografia abordada é ampla, uma vez que a temática da tese é abrangente. Trabalhou-se primeiramente sobre o tema do desenvolvimento urbano e planejamento em Minas Gerais e em seguida, foi feita uma revisão bibliográfica sobre políticas públicas no Brasil e em Minas Gerais. A seguir, se focalizou os textos dos PNDs e do PROECI, buscando ressaltar as atitudes em cada um dos municípios escolhidos como estudo de caso.

Para a discussão sobre as questões ambientais e de formação do ambiente urbano, foi feita uma análise dos elatórios de Conferências Internacionais sobre Meio Ambiente e Assentamentos Humanos, organizadas pela Organização das Nações Unidas (ONU). A seguir, foram pesquisados textos e livros que tratavam da evolução da questão ambiental no Brasil e em termos mundiais, além daqueles que 
desenvolviam a conceituação sobre 'sustentabilidade' e 'desenvolvimento sustentável'.

Considerando que os anos 1970 correspondem intensificou e à ampliação da discussão sobre a questão ambiental em âmbito mundial, procurou-se a pertinência do ambiente urbano como locus de análise ambiental.

Para $\circ$ avanço desta análise, o termo 'sustentabilidade', amplamente adotado e difundido merece, no entanto, de qualificação clara. Recorrendo aos enfoques teóricos desde a ampliação das discussões ambientais na tentativa de determinação do que seria 'sustentabilidade' para o ambiente urbano, procura-se estabelecer que conceito que será utilizado neste trabalho.

Este conceito foi obtido pela elaboração de uma matriz que busca agregar os critérios conforme revisão bibliográfica determinante para a sustentabilidade do ambiente urbano.

A coerência ou legitimidade das ações de planejamento estatais como potencialmente transformadores da qualidade do ambiente das cidades brasileiras passa a ser testada frente à matriz conceitual adotada.

A análise dos textos das Conferências Internacionais sobre Meio Ambiente e Assentamentos Humanos, bem como o texto dos planos, programas e políticas de autoria do Estado, dão suporte à pesquisa bibliográfica, possibilitando subsídios à construção dos indicadores da Matriz de Qualidade do Ambiente Urbano.

Ao construir a matriz com o apoio de um acervo teórico existente, propõe-se a aplicação desta ao objeto de análise. Pela aferição do teorizado com a série histórica de dados sobre as cidades em análise, verifica-se a aplicabilidade da matriz e a possibilidade das cidades se enquadrarem àquilo que ela determina.

Entre estes dados levantados estão presentes aqueles sobre as localidades, como as séries históricas do Censo, Índice de Desenvolvimento Humano (IDH) e 
Índice de Qualidade de Vida Urbana (IQVU) possibilitando uma dimensão do resultado das interferências das políticas e programas urbanos feitos e os resultados alcançados no período analisado.

\subsection{COLETA DE DADOS}

Os levantamentos dos dados foram realizados em relação aos textos e materiais dos planos, projetos e políticas federais do período proposto $-1970 / 1980$ referentes à políticas urbanas dos, II e II PNDs, além do documento "Programa de Ação do Governo na Área do Desenvolvimento Urbano - 1975/79", documento este originário do II PND.

Sendo originário dos II PND, o PNCCPM é analisado com referência aos recursos destinados a cada uma das cidades aqui analisadas como estudo de caso.

Quanto ao estado de Minas foi analisado o acervo da FJP sobre o Programa Estadual de Cidades de Porte Intermediário, sendo os volumes dedicados à concepção, metodologia e proposições do programa. Foram também analisados planos municipais, dados fornecidos pelas prefeituras municipais, dados da Fundação Instituto Brasileiro de Geografia e Estatística (IBGE) e indicadores de qualidade de vida.

\subsubsection{Indicadores de sustentabilidade urbana}

A 'sustentabilidade' tem sido um termo de difícil adesão, principalmente frente à aceitação de parâmetros pouco precisos.

Ao fazer parte da discussão sobre fixação de parâmetros de qualidade do ambiente humano que seja menos danosa ou que os cause danos de forma menos 
irreversível $^{3}$ que o que vem ocorrendo pela ocupação humana, principalmente em países em desenvolvimento, articula-se a discussão da sustentabilidade à lógica do desenvolvimento e assim, a do planejamento urbano e regional.

Assim sendo, no desenvolvimento sobre qualidade do ambiente urbano, procura-se definir parâmetros que possam ser mensuráveis e verificar a qualidade 'sustentabilidade' ao ambiente analisado. Foram retiradas da bibliografia caracterizações pertinentes ao conceito, visando estabelecer critérios de análise para o sistema urbano, estabelecendo um quadro conceitual de abordagem.

Selecionou-se a partir de um grande número de quesitos necessários para elaboração de um quadro conceitual, desde aqueles relativos ao fluxo de energia até os pertinentes à gestão do espaço urbano. Para fins deste trabalho, foram delimitadas algumas características consideradas imprescindíveis à definição do termo, que definiram a Matriz de Qualidade do Ambiente Urbano, que terá seu desenvolvimento detalhado a seguir.

\subsubsection{Densidade}

Acselrad (2001) evidencia duas contradições em relação à determinação o aspecto 'densidade' a ser definido como adequado e sustentável em uma ocupação humana. Ao mesmo tempo em que a proposta mundial é a da concentração espacial da cidade, existe também a deseconomia de escala causada pela excessiva concentração. Internamente a esta deseconomia, estão o excesso de atrativos das áreas centrais, como por exemplo, a geração de um grande número de viagens tendo-as como destino final; a geração de ruído e poluição atmosférica do ar, 
causando um constrangimento à qualidade do ambiente desta região em detrimento do restante da cidade; a solicitação permanente da infra-estrutura existente, fazendo com que ela sofra reformas quase que ininterruptamente, o que ocasiona os reinvestimentos públicos para na melhoria de uma mesma área constantemente; a valorização imobiliária que premente, que faz com que esta área seja sempre prioridade para estes mesmos investimentos; resultando em uma densidade populacional concentrada nesta área.

Ao mesmo tempo, as deseconomias referem-se também ao impacto da concentração para além das fronteiras da área urbana do município, como, por exemplo, a necessidade da construção de grandes hidrelétricas para garantir o abastecimento energético das concentrações urbanas. Para além deste tipo de abastecimento, ocorre também a concentração fundiária que visa à produção de alimentos a preços competitivos. Uma vez que a aglomeração urbana torna-se tão densa que não existem mais locais para a produção de produtos para o abastecimento da mesma - sejam eles: alimentos, produtos para indústria de transformação - e que as dimensões das cidades fazem com que o preço da terra no seu entorno torne-se tão competitivo, o distanciamento do espaço para produção dos bens primários faz com que a pequena unidade de produção familiar torne-se pouco competitiva, o que acaba reforçando a concentração fundiária.

Embora a concentração seja também apregoada pelas conferências internacionais, todos estes matizes de sua adoção precisam ser levados em consideração.

Acioly Jr. e Davidson (1998) fazem uma série de colocações sobre densidade em diversos países e enfatiza que a densidade está bastante ligada às tradições e opções sociais. Segundo estes autores, deve ser observado, antes de 
mais nada, a presença da infra-estrutura para dar suporte ao adensamento, considerando a tecnologia adotada e sua capacidade de ação.

Considerando a peculiaridade de cada tipo de sociedade, esboça-se a seguir a densidade para o caso brasileiro, tomando como padrão uma quadra quadrada de faces de $100 \mathrm{~m} \times 100 \mathrm{~m}^{4}$, utilizada para ocupação unifamiliar, de lotes médios de $360 \mathrm{~m}^{2}$, o que perfaz um total de aproximadamente 30 famílias por quadra. O Censo de 2000 demonstra ser o tamanho médio da família brasileira de 3,73 habitantes por família, o que resulta em uma densidade média de aproximadamente 119 hab/ha para a quadra em questão.

Considerando as colocações feitas por Freitas (2005), a maioria das cidades brasileiras possui densidades entre 73 e 144 hab/ha, consideradas densidades médias e sustentáveis. Valores menores seriam considerados baixos e demandariam custos com infra-estrutura, maiores deslocamentos e consumo de terras. Maiores valores, considerados altos para os padrões brasileiros, sobrecarregariam as infra-estruturas e, sobretudo, iriam de encontro a outro importante fator que é o clima urbano, pois em regiões tropicais quentes e úmidas é necessário contar com espaço suficiente para que haja ventilação e vegetação para amenizar os efeitos dos elementos climáticos.

Freitas coaduna com Acioly Jr. e Davidson:

As densidades serão altas ou baixas, não apenas em função de unidades ou habitantes divididos por uma determinada área, mas também, em função de condições de infra-estrutura, realidade sóciocultural dos países abordados. Todos esses fatores somados é que determinarão a qualidade de vida. (FREITAS, 2005, p. 120.)

Portanto, a estimativa a quadra de $100 \times 100 \mathrm{~m}$ seria adequada. Cabe que ressaltar que supõe-se uma área de qualidade de infra-estrutura adequada, ou seja, 
com todos os equipamentos urbanos ${ }^{5}$ previstos pela Lei n. $6.766 / 79$ - Lei Federal de Parcelamento do Solo.

\subsubsection{Os indicadores desenvolvidos pela ONU}

\section{Os indicadores do Habitat}

A partir da Conferência das Nações Unidas sobre Assentamentos Humanos (Habitat I), ocorridas em 1976 em Vancouver, passam a serem discutidas quais seriam as condições mínimas que deveriam estar presentes para que o ambiente urbano pudesse promover o desenvolvimento humano. Entre estas condições são citadas a necessidade de qualificar os assentamentos com condições mínimas de habitação, sendo estas, a da própria moradia, com número de cômodos adequados ao tamanho das famílias, utilização de materiais adequados na construção das edificações, presença de infra-estrutura básica - abastecimento de água tratada, esgotamento sanitário e destinação de água servida e lixo.

Dos dados expostos, alguns itens são de mensuração possível podendo serem transformados em indicadores para a construção de uma matriz de análise:

I - $\quad$ Adequação quanto à Infra-estrutura:

5 Parágrafo Único - Consideram-se urbanos os equipamentos públicos de abastecimento de água, serviços de esgoto, energia elétrica, coletas de águas pluviais, rede telefônica e gás canalizado. (BRASIL, 1979).

A Lei 6766/79, que Dispõe sobre o Parcelamento do Solo Urbano apresenta as seguintes classificações:

"Capítulo II - DOS REQUISITOS URBANÍSTICOS PARA LOTEAMENTO

II - Os lotes terão área mínima de $125^{2}$ (cento e vinte e cinco metros quadrados) e frente mínima de $5 \mathrm{~m}$ (cinco metros), salvo quando a legislação estadual ou municipal determinar maiores exigências ou quando o loteamento se destinar à urbanização específica ou edificação de conjuntos habitacionais de interesse social, previamente aprovados pelos órgãos públicos competentes;

$\S 2^{\circ}$ - Consideram-se comunitários os equipamentos públicos de educação, cultura, saúde, lazer e similares.

Parágrafo Único - Consideram-se urbanos os equipamentos públicos de abastecimento de água, serviços de esgoto, energia elétrica, coletas de águas pluviais, rede telefônica e gás canalizado." (BRASIL, 1979)

Em sua modificação pela Lei 9785/99, fica estabelecido que:

"Art 3

$\S 5^{\circ}$ Consideram-se infra-estrutura básica os equipamentos urbanos de escoamento das águas pluviais, iluminação pública, redes de esgoto sanitário e abastecimento de água potável, e de energia elétrica pública e domiciliar e as vias de circulação pavimentadas ou não." (BRASIL, 1979). 
a. Abastecimento domiciliar de água - seria o abastecimento fornecido por meio de uma rede geral de abastecimento do município que proporcione água nas moradias;

b. Coleta de água servida, com destinação final - considerada a existência de rede de esgotamento sanitário, com destinação final adequada para o esgoto. Esta destinação final adequada significa esgoto que se direcione a uma estação de tratamento, para ser novamente adaptado ao curso da bacia hidrográfica a que pertencem os mananciais que deram origem à água abastecida;

c. Coleta e adequada disposição do lixo doméstico - também aqui, a adequada destinação do lixo refere-se à existência de um aterro sanitário, no qual ocorra tanto a reciclagem do material passível de, como a compostagem do material orgânico, que possibilita a geração de recurso energético - gás e biomassa;

d. Infra-estrutura viária - correta hierarquização das vias, possibilitando que sejam utilizadas sem sobrecarga do sistema como um todo. Assim sendo, as vias de articulação devem possuir uma caixa de via - largura compatível com sua função, uma declividade que permita o acesso dos variados modos de transporte - transporte individual, coletivo e de carga, e um desenho adequado que permita ao motorista uma boa execução do trajeto;

e. Existência de áreas verdes suficientes ao exercício das atividades de lazer;

f. Existência de equipamentos sociais de educação e saúde - a presença destes em adequada quantidade e qualidade para sua população. 
II - $\quad$ Adequação quanto à concentração humana;

III - Adequação quanto à qualidade da habitação - com número de cômodos adequados ao tamanho das famílias, utilização de materiais adequados na construção das edificações, ou seja, materiais que sejam permanentes, propiciando uma habitação segura e duradoura.

Foi também considerada imprescindível a geração de emprego e renda para que as populações pudessem habitar em seu espaço. $O$ fim da segregação e das grandes questões sociais advindas da estrutura fundiária concentradora foram também ressaltadas. A Declaração de Assentamentos Humanos definiu a habitação como um direito humano básico que deve ser assegurado pelos governos, sendo importante assegurar comunidades não segregacionistas, mais equilibradas, com a combinação de diferentes grupos sociais, ocupações e moradias. (ONU, 1976).

Isto importa diretamente a sociedades cuja terra é privada e a existência de concentração de renda manifesta-se principalmente através da concentração fundiária, resultando na segregação sócio-espacial, na qual apenas uma pequena parte da população tem acesso a renda, ficando o restante alijado de qualquer dos dois acessos - renda e terra.

\section{Indicadores da Agenda 21}

Em 1992 ocorreu no Rio de Janeiro a Conferência das Nações Unidas para o Meio Ambiente e o Desenvolvimento, a ECO-92. A resolução dela advinda tem o nome de Agenda 21, sendo uma agenda a ser cumprida para o século XXI, pelos países que assinaram a declaração, com resoluções pertinentes às questões ambientais. Para a existência de uma cidade sadia, a Agenda 21 estabeleceu que:

1. sejam aperfeiçoados o manejo dos assentamentos humanos;

2. seja promovida a existência integrada de infra-estrutura ambiental: água, saneamento, drenagem e manejo de resíduos sólidos; 
3. sejam promovidos sistemas sustentáveis de energia e transporte nos assentamentos humanos;

4. seja promovido o planejamento e o manejo dos assentamentos humanos localizados em áreas sujeitas a desastres;

5. sejam promovidas atividades sustentáveis na indústria da construção;

6. seja promovido o desenvolvimento dos recursos humanos e da capacitação institucional e técnica para o avanço dos assentamentos humanos. (ONU, 1992).

\section{Indicadores dos Objetivos do Milênio}

Em setembro de 2000, a Assembléia Geral das Nações Unidas adotou a Declaração do Milênio que agrupa e sintetiza os objetivos para o desenvolvimento que foram acordados nas conferência globais. Os oito principais objetivos são chamados "Objetivos de Desenvolvimento do Milênio" e são monitorados a partir de 35 indicadores setoriais. Os objetivos foram resultado de um acordo consensual entre as delegações nacionais presentes naquela Assembléia Geral ${ }^{6}$.

A Declaração do Milênio inclui um número de elementos diretamente relacionados com os critérios e vigências do Programa das Nações Unidas para os Assentamentos Humanos (UN-Habitat), incluindo acesso à água, saneamento básico, promoção dos direitos humanos, democracia, governabilidade e igualdade de gênero.

Para fins deste trabalho, a parte que diz respeito a fixação de índices de sustentabilidade urbana está contida no Objetivo 7 e dentro deles, na Meta 11.

Objetivo 7: Garantir a sustentabilidade ambiental

6 O acompanhamento do desenvolvimento dos Objetivos do Milênio fica a cargo do Escritório Regional para América Latina e Caribe (ROLAC) dentro do Programa UN-Habitat 
Meta 09: Integrar os princípios do desenvolvimento sustentável nas políticas e programas nacionais e reverter a perda de recursos ambientais.

Meta 10: Reduzir pela metade, até 2015, a proporção da população sem acesso permanente e sustentável a água potável segura.

Meta 11: Até 2020, ter alcançado uma melhora significativa nas vidas de pelo menos 100 milhões de habitantes de bairros degradados.

\subsection{Indicadores de Meta 11 - Objetivos de Desenvolvimento do Milênio}

1. Proporções de domicílios com melhoria de acesso ao abastecimento de água;

2. Proporções de domicílios com melhoria de acesso de instalações sanitárias

3. Proporção de famílias cuja posse da habitação que ocupam esteja assegurada, ou seja:

a. Existe documentação que pode ser usada para garantir a posse com segurança;

b. Exista proteção de direito e de fato contra as desocupações forçadas

4. Proporção de domicílio cuja benfeitoria pode ser considerada durável ou permanente, ou seja, construída fora de áreas de risco, com estrutura suficientemente adequada para proteger seus habitantes das inclemências do tempo;

5. Proporção de domicílios com menos de três pessoas por habitação.

\section{Indicadores da Agenda Habitat}

Na elaboração da Agenda Habitat, resultante da II Conferência das Nações Unidas sobre Assentamentos Humanos (Habitat II), em Istambul, 1996, os estados membros das Nações Unidas e os sócios da Agenda Habitat solicitaram a UNHabitat para continuar o monitoramento das condições urbanas na escala mundial. 
Também se comprometeram a monitorar as condições urbanas em seus próprios paises e informar regularmente sobre as inovações.

São os seguintes os indicadores urbanos, monitorados pela Agenda Habitat e em acordo com os Objetivos do Milênio:

- Indicador 1: Estruturas duráveis;

- $\quad$ Indicador 2: Área suficiente para viver;

- Indicador 3: Preço da habitação e coeficiente de habitações acrescidas no montante total;

- $\quad$ Indicador 4: Posse segura;

- Indicador 5: Moradia assegura;

- Indicador 6: Despejos;

- $\quad$ Indicador 7: Financiamento de habitações;

- $\quad$ Indicador 8: Relação preço da terra versus ingresso no mercado de terra;

- $\quad$ Indicador 9: Acesso à água potável;

- Indicador 10: Acesso melhorado ao saneamento;

- Indicador 11: Conexões internas ao domicílio;

- Indicador 12: Mortalidade infantil;

- $\quad$ Indicador 13: Homicídio;

- $\quad$ Indicador 14: Violência urbana;

- $\quad$ Indicador 15: Incidência de portadores de HIV;

- Indicador 16: Habitações pobres;

- Indicador 17: Taxa de alfabetização;

- $\quad$ Indicador 18: Inclusão de gênero;

- Indicador 19: Taxa de escolaridade;

- Indicador 20: Parlamentares mulheres; 
- Indicador 21: Crescimento da população urbana;

- Indicador 22: Assentamentos planejados;

- Indicador 23: Preço da água;

- Indicador 24: Consumo da água;

- Indicador 25: Águas residuais tratadas;

- Indicador 26: Eliminação dos dejetos sólidos;

- Indicador 27: Recolhimento regular de dejetos sólidos;

- Indicador 28: Prevenção de desastres e instrumentos de mitigação;

- Indicador 29: Proporção de habitações sujeitas a risco;

- Indicador 30: Tempo de translado casa $\times$ trabalho;

- Indicador 31: Modos de transporte;

- Indicador 32: Nível de implementação de planos ambientais locais;

- Indicador 33: Emprego formal;

- Indicador 34: Produção urbana;

- Indicador 35: Emprego formal;

- Indicador 36: Ingressos no governo local;

- Indicador 37: Descentralização;

- Indicador 38: Participação cidadã;

- Indicador 39: Participação de eleitores;

- Indicador 40: Associações civis;

- Indicador 41: Transparência e responsabilidade.

A sociedade ainda não conta com nenhuma normatização sobre os graus de agressões maiores ou menores. Os indicadores prescindem de uma regulamentação de sua utilização, através da fixação de parâmetros ou classes dentro das quais possam ser considerados como satisfatórios, suficientes ou deficitários, por exemplo. 
Cabe ressaltar que das considerações registradas como necessárias à sustentabilidade do ambiente humano indicados pela Agenda 21 até as metas colocadas pelos Objetivos do Milênio ou pelos Indicadores Urbanos, ocorreu um avanço no sentido de uma maior especificação de como seriam estes objetivos.

\subsubsection{Outros indicadores}

\section{1. Índice de Desenvolvimento Humano Municipal - IDH-Municipal}

O IDH-Municipal foi desenvolvido pela FJP e do Instituto de Pesquisas Econômicas Aplicadas (IPEA) a partir do IDH da ONU.

Para a formação do IDH, além do componente relativo à renda foram associados os valores relativos à longevidade e nível de educação da população.

O IDH-Municipal é uma versão para os municípios no qual foram feitas adaptações nos indicadores de renda e de educação com o propósito de que o indicador resultante pudesse refletir mais efetivamente o desenvolvimento humano da população residente em cada município. (GUIMARÃES; JANUZZI, 2005).

\section{2. Índice de Qualidade de Vida Urbana - IQVU}

O IQVU foi desenvolvido através de uma parceria entre a Prefeitura Municipal de Belo Horizonte (PBH) e a Pontifícia Universidade Católicas de Minas (PUC Minas).

O IQVU foi construído para ser um instrumento de distribuição mais eqüitativa e justa dos recursos públicos municipais.

Para seu cálculo, considerourse:

- a oferta de serviços urbanos essenciais existentes no local;

- $\quad$ o acesso dos moradores a serviços oferecidos em locais mais ou menos distantes, utilizando o transporte coletivo. 
Foram consideradas as seguintes variáveis:

- Habitação;

- Infra-estrutura urbana;

- $\quad$ Saúde;

- $\quad$ Educação;

- $\quad$ Serviços urbanos;

- $\quad$ Segurança urbana;

- $\quad$ Abastecimento;

- $\quad$ Meio Ambiente;

- $\quad$ Cultura;

- $\quad$ Esporte;

- $\quad$ Assistência Social. (PREFEITURA..., 1996).

Para o trabalho aqui desenvolvido serão utilizados os parâmetros estabelecidos pela ONU que possibilitem uma qualificação física do ambiente urbano. Para esta qualificação física fazem-se importantes os aspectos tais como abastecimento e coleta de água e de resíduos sólidos, qualidade das habitações, garantia de posse das mesmas, dentre outros, que serão especificados a seguir.

\subsubsection{Proposta de Matriz de Sustentabilidade}

A exposição dos parâmetros abordada acima visa possibilitar a definição de indicadores de maior relevância para serem atribuídos para a matriz aqui estabelecida.

Cabe ainda ressaltar que a composição da matriz e sua interpretação serão feita método da Cartografia que trabalha com a Semiologia Gráfica, o que permite respostas visuais imediatas ao leitor, que poderá aprofundar suas análises no material quantitativo que deu origem a ela. A representação gráfica utilizada para 
apresentação da matriz segue as técnicas da Grafique, técnica de representação cartográfica que busca transmitir a informação de forma mais precisa e amigável.

Em tal abordagem, o material a ser produzido deve preferencialmente utilizar os padrões de preto a branco, passando pelas nuances de cinza. Desta forma a informação é mais facilmente reproduzida do que quando da utilização de cores. As cores, ao serem reproduzidas em cópias xerográficas, tentem a sofrer distorção, causando a perda da informação.

A intensidade das tonalidades definidas é trabalhada como uma valoração de forma a ser rapidamente compreendida pelo leitor. Portanto, quando se deseja enfatizar uma informação utiliza-se a cor preta, que será a primeira a ser captada pela visão humana. Pode-se usar a cor escura para abordar as características que parecem ser mais relevantes, mas alarmantes. Quando a informação for positiva, ela poderá ter tonalidade clara, pois seu impacto é menos importante para os fins analisados.

\subsubsection{Matriz de Sustentabilidade}

Para compor esta matriz de sustentabilidade foram estudadas três formas de organização, conforme abaixo.

\section{Matriz 1 - Primeira composição}

I - $\quad$ Adequação quanto à infra-estrutura

1 - Abastecimento domiciliar de água

2 - Coleta da água servida, com destinação final

3 - Coleta e adequada disposição do lixo doméstico

4 - Infra-estrutura viária

5 - $\quad$ Presença de áreas verdes 
6 - Existência de equipamentos sociais de saúde e educação

II - $\quad$ Adequação quanto à concentração;

III - Adequação quanto à qualidade da habitação

\subsubsection{Matriz de sustentabilidade - primeiras alterações}

Nas páginas anteriores, foram relacionados ao todo 60 indicadores, tanto pela ONU quanto por outros indicadores sintéticos para fins desta análise. Estes indicadores foram reagrupados de acordo com suas características, nas seguintes categorias:

I. Quanto à infra-estrutura urbana:
a. Abastecimento água;
b. Saneamento;
c. Habitação;
d. Desenvolvimento técnico/tecnológico
e. Meio Ambiente;
f. Infra-estrutura viária;
g. Existência de áreas verdes suficientes ao exercício das atividades de lazer.

II. Quanto às instituições sociais:
a. Democratização;
b. Meio ambiente;
c. Social;
d. Saúde;
e. Educação. 
Neste agrupamento há indicadores relevantes para este trabalho que foram

incorporados na composição final da matriz. São eles:

Deste modo, foram organizados dois quadros contendo infra-estrutura e instituições sociais.

Quadro 2 - Grupamentos quanto à infra-estrutura urbana

\begin{tabular}{|c|c|c|}
\hline Categoria & & indicador \\
\hline \multirow{4}{*}{$\begin{array}{l}\text { Abastecimento domiciliar de } \\
\text { água }\end{array}$} & \multicolumn{2}{|c|}{ Acesso à água potável; } \\
\hline & \multicolumn{2}{|c|}{ Proporções de domicílios com melhoria de acesso ao abastecimento de água; } \\
\hline & \multicolumn{2}{|c|}{ Consumo da água; } \\
\hline & \multicolumn{2}{|c|}{ Preço da água; } \\
\hline \multirow{8}{*}{ Saneamento } & \multicolumn{2}{|c|}{ Coleta de água servida, } \\
\hline & \multicolumn{2}{|c|}{ Proporções de domicílios com melhoria de acesso de instalações sanitárias } \\
\hline & \multicolumn{2}{|c|}{ Acesso melhorado ao saneamento } \\
\hline & \multicolumn{2}{|c|}{ Águas residuais tratadas } \\
\hline & \multicolumn{2}{|c|}{ Coleta e adequada disposição do lixo } \\
\hline & \multicolumn{2}{|c|}{ Recolhimento regular de dejetos sólidos; } \\
\hline & \multicolumn{2}{|c|}{ Eliminação dos dejetos sólidos; } \\
\hline & \multicolumn{2}{|c|}{$\begin{array}{l}\text { Promoção integrada de infra-estrutura ambiental: água, saneamento, drenagem e manejo } \\
\text { de resíduos sólidos; }\end{array}$} \\
\hline \multirow{13}{*}{ Habitação } & & Habitação pobres - percentual da população \\
\hline & \multirow{2}{*}{ Densidade } & Área suficiente para viver \\
\hline & & Proporção de domicílios com menos de três pessoas por habitação \\
\hline & \multirow{4}{*}{ Benfeitoria } & $\begin{array}{l}\text { Utilização materiais permanentes que propiciem uma habitação segura e } \\
\text { duradoura }\end{array}$ \\
\hline & & $\begin{array}{l}\text { Estrutura suficientemente adequada para proteger seus habitantes das } \\
\text { inclemências do tempo; }\end{array}$ \\
\hline & & Conexões hidro-sanitárias internas ao domicílio \\
\hline & & Construída fora de áreas de risco \\
\hline & \multirow{2}{*}{ Posse } & habitação que ocupam esteja assegurada, \\
\hline & & Exista proteção de direito e de fato contra as desocupações forçadas \\
\hline & \multirow{4}{*}{ Oferta } & Posse segura \\
\hline & & Financiamento de habitações \\
\hline & & Relação preço da terra versus ingresso no mercado de terra \\
\hline & & $\begin{array}{l}\text { Preço da habitação e coeficiente de habitações acrescidas no montante } \\
\text { total; }\end{array}$ \\
\hline \multirow{6}{*}{$\begin{array}{l}\text { Desenvolvimento } \\
\text { tecnológico }\end{array}$} & \multicolumn{2}{|c|}{ Aperfeiçoados o manejo dos assentamentos humanos } \\
\hline & \multicolumn{2}{|c|}{ Sistemas sustentáveis de energia e transporte nos assentamentos humanos } \\
\hline & \multicolumn{2}{|c|}{$\begin{array}{l}\text { Planejamento e o manejo dos assentamentos humanos localizados em áreas sujeitas a } \\
\text { desastres }\end{array}$} \\
\hline & \multicolumn{2}{|c|}{ Prevenção de desastres e instrumentos de mitigação } \\
\hline & \multicolumn{2}{|c|}{ Sejam promovidas atividades sustentáveis na indústria da construção } \\
\hline & \multicolumn{2}{|c|}{$\begin{array}{l}\text { Seja promovido o desenvolvimento dos recursos humanos e da capacitação institucional e } \\
\text { técnica para o avanço dos assentamentos humanos }\end{array}$} \\
\hline \multirow{2}{*}{ Infra-estrutura viária } & \multicolumn{2}{|c|}{ Modos de transporte } \\
\hline & \multicolumn{2}{|c|}{ Sistemas sustentáveis de transporte } \\
\hline \multicolumn{3}{|l|}{$\begin{array}{l}\text { Existência de áreas verdes } \\
\text { suficientes ao exercício das } \\
\text { atividades de lazer }\end{array}$} \\
\hline $\begin{array}{l}\text { Adequação quanto } \\
\text { concentração humana; }\end{array}$ & & \\
\hline
\end{tabular}

FONTE: Dados compilados pelo autor. 
Quadro 3 - Grupamentos quanto às instituições sociais

\begin{tabular}{|l|l|}
\hline \multicolumn{1}{|c|}{ Categoria } & \\
\hline \multirow{5}{*}{ Democratização } & Parlamentares mulheres \\
\cline { 2 - 2 } & Participação cidadã \\
\cline { 2 - 2 } & Participação de eleitores \\
\cline { 2 - 2 } & Ingressos no governo local \\
\cline { 2 - 2 } & Associações civis \\
\cline { 2 - 2 } & Transparência e responsabilidade \\
\hline \multirow{5}{*}{ Meio Ambiente } & Nível de implementação de planos ambientais locais \\
\cline { 2 - 2 } & Descentralização \\
\hline \multirow{5}{*}{ Sociais } & Crescimento da população urbana \\
\cline { 2 - 2 } & Mortalidade infantil \\
\cline { 2 - 2 } & Homicídio \\
\cline { 2 - 2 } & Emprego formal \\
\cline { 2 - 2 } & Violência urbana \\
\cline { 2 - 2 } & Desemprego \\
\cline { 2 - 2 } & Tempo de translado casa x trabalho \\
\cline { 2 - 2 } & Produção urbana \\
\cline { 2 - 2 } & Abastecimento \\
\cline { 2 - 2 } & Existência de recurso \\
\hline \multirow{5}{*}{ Eaúde } & Existência de equipamentos sociais de educação e saúde \\
\cline { 2 - 2 } & Incidência de portadores de HIV \\
\hline \multirow{5}{*}{ Educação } & Taxa de escolaridade \\
\cline { 2 - 2 } & Taxa de alfabetização \\
\hline
\end{tabular}

FONTE: Conferências Internacionais.

Autoria:Dados compilados pelo autor.

O primeiro (Quadro 2) foi utilizado para definição da matriz de qualidade de ambiente urbano, sendo o segundo (Quadro 3) descartado por se tratar de aspectos sociais sem referenciais de locais urbanos.

Numa etapa posterior, foram feitos ajustes dos indicadores de modo a eliminar sobreposições, tendo-se então obtido a Matriz de Indicadores de Qualidade Urbana. Esta matriz conta com sete categorias de indicadores, quais seja: Abastecimento domiciliar de água; Saneamento básico; Habitação; Desenvolvimento técnico-tecnológico; Infra-estrutura viária; Existência de áreas verdes suficientes ao exercício das atividades de lazer e Adequação quanto à concentração humanaDensidade população/ área urbanizada.

Cada categoria é formada por um conjunto de indicadores que foram sistematizados para aferir a qualidade do ambiente das áreas urbanas (Quadro 4). 
Quadro 4 - $\quad$ Matriz de Indicadores de qualidade de vida urbana

\begin{tabular}{|c|c|c|}
\hline Categoria & \multicolumn{2}{|r|}{ Indicadores } \\
\hline \multirow{2}{*}{$\begin{array}{l}\text { 1.Abastecimento domiciliar de } \\
\text { água }\end{array}$} & \multicolumn{2}{|c|}{ Acesso à água potável } \\
\hline & \multicolumn{2}{|c|}{ Proporções de domicílios com melhoria de acesso ao abastecimento de água } \\
\hline \multirow{7}{*}{ 2.Saneamento básico } & \multicolumn{2}{|c|}{ Coleta de água servida } \\
\hline & \multicolumn{2}{|c|}{ Proporções de domicílios com melhoria de acesso ao saneamento } \\
\hline & \multicolumn{2}{|c|}{ Proporções de domicílios com melhoria de acesso à instalações sanitárias } \\
\hline & \multicolumn{2}{|c|}{ Águas residuais tratadas } \\
\hline & \multicolumn{2}{|c|}{ Recolhimento regular de dejetos sólidos } \\
\hline & \multicolumn{2}{|c|}{ Adequada disposição do lixo } \\
\hline & \multicolumn{2}{|c|}{$\begin{array}{l}\text { Promoção integrada de infra-estrutura ambiental: água, saneamento, drenagem e } \\
\text { manejo de resíduos sólidos }\end{array}$} \\
\hline \multirow{10}{*}{ 3.Habitação } & \multicolumn{2}{|c|}{ Percentual de população acima do limiar da pobreza } \\
\hline & \multirow{2}{*}{ Densidade } & Área suficiente para viver \\
\hline & & Proporção de domicílios com menos de três pessoas por cômodo \\
\hline & \multirow{3}{*}{ Benfeitoria } & $\begin{array}{l}\text { Utilização materiais permanentes que propiciem uma habitação segura } \\
\text { e duradoura }\end{array}$ \\
\hline & & Conexões hidro-sanitárias internas ao domicílio \\
\hline & & Construída fora de áreas de risco \\
\hline & \multirow{4}{*}{ Posse } & Habitação cuja ocupação esteja assegurada \\
\hline & & Financiamento de habitações \\
\hline & & Relação preço da terra versus ingresso no mercado de terra \\
\hline & & $\begin{array}{l}\text { Preço da habitação e coeficiente de habitações acrescidas no montante } \\
\text { total }\end{array}$ \\
\hline \multirow{5}{*}{$\begin{array}{l}\text { 4.Desenvolvimento } \\
\text { tecnológico }\end{array}$} & \multicolumn{2}{|c|}{ Aperfeiçoados o manejo dos assentamentos humanos } \\
\hline & \multicolumn{2}{|c|}{ Sistemas sustentáveis de energia e transporte nos assentamentos humanos } \\
\hline & \multicolumn{2}{|c|}{ Prevenção de desastres e instrumentos de mitigação } \\
\hline & \multicolumn{2}{|c|}{ Atividades sustentáveis na indústria da construção } \\
\hline & \multicolumn{2}{|c|}{ Capacitação institucional e técnica para o avanço dos assentamentos humanos } \\
\hline \multirow{2}{*}{ 5.Infra-estrutura viária } & \multicolumn{2}{|c|}{ Modos de transporte } \\
\hline & \multicolumn{2}{|c|}{ Sistemas sustentáveis de transporte } \\
\hline \multicolumn{3}{|c|}{ 6.Existência de áreas verdes suficientes ao exercício das atividades de lazer } \\
\hline \multicolumn{3}{|c|}{ 7.Adequação quanto à concentração humana- Densidade população/ área urbanizada } \\
\hline
\end{tabular}

Analisando esta matriz (Quadro 4), observa-se que dos 28 indicadores aqui dispostos para avaliar o ambiente urbano e a transformação advinda da ação das políticas públicas, 12 são de fácil obtenção junto ao IBGE. Os demais indicadores não foram encontrados para todos os municípios e a inexistência da informação advém também de outros fatores, tais como: mudança de metodologia dos levantamentos feitos pelo IBGE para o recenseamento, o que impossibilita a conformação de séries histórica contínuas de análise; a inexistência de institutos municipais de planejamento, ficando as informações a cargo das secretarias municipais ligadas à gestão urbana, que não possuem continuidade de suas ações de uma gestão de governo para outro e que construíram os indicadores com 
metodologias distintas, não sendo adequada à comparação entre eles para fins científicos.

Tais dificuldades são encontradas com muita freqüência e de longo conhecidas na prática do planejamento urbano.

\subsubsection{Análise da matriz resultante de Qualidade do Ambiente Urbano}

Os indicadores aqui reagrupados tem sua origem nas conferências mundiais anteriormente mencionadas. Assim sendo, no Habitat I foram definidos alguns critérios que seriam considerados relevantes para a existência de condições mínimas de habitabilidade nos espaços urbanos. Os critérios presentes nas categorias 1 - Abastecimento domiciliar de água e 2 - Saneamento básico, são inicialmente colocados pelo Habitat I. Seria então, o acesso à água potável e ao saneamento básico indicadores fundamentais na consolidação de um ambiente urbano saudável. Compreende-se que sem estes dois indicadores está seriamente comprometida a qualidade de um ambiente urbano.

O indicador 'Promoção integrada de infra-estrutura ambiental: água, saneamento, drenagem e manejo de resíduos sólidos' é pertinente à Agenda 21, cujo texto procura dar grande relevância aos aspectos integrados de desenvolvimento da técnica e da tecnologia local, além da importância dada à gestão e ao manejo das políticas e recursos ambientais.

$\mathrm{Na}$ Declaração do Milênio tornou-se meta ressaltar a melhoria ocorrida ao longo dos anos com relação ao acesso à infra-estrutura de água e saneamento. Passa a configurar então, nas categorias de indicadores 'Abastecimento domiciliar de água' e 'Saneamento básico' o termo 'melhoria' do acesso à infra-estrutura. Ele indica percentualmente qual o aumento ocorrido entre determinado período de tempo, no fornecimento destes serviços. 
Na categoria 3 - Habitação, ocorre também a presença da 'melhoria', agora se referindo às 'Conexões hidro-sanitárias internas ao domicílio'. Ao mesmo tempo em que as conexões hidro-sanitárias fazem parte da qualidade da benfeitoria, dizem respeito também à ampliação da qualidade do saneamento presente.

A matriz apresenta na categoria 3 - Habitação, indicadores referentes à Declaração do Milênio, que propõe um avanço na discussão da habitação ao incorporar fatores que são pertinentes à organização social de cada cidade com ênfase na concentração de renda e acesso à terra. São os indicadores mais difíceis de serem levantados pela exigência de informações tais como: 'Existência de proteção de direito e de fato contra as desocupações forçadas' ou 'Preço da habitação' e 'Coeficiente de habitações acrescidas no montante total'. Observa-se que são indicadores que necessitam de um estudo próprio, não estando disponíveis para consulta no órgão municipais de planejamento e gestão.

Com relação à categoria 4 - 'Desenvolvimento técnico-tecnológico' fica evidente pela exposição da Agenda 21 uma maior interação entre os níveis de desenvolvimento de uma sociedade e a forma de proposição e execução consagrada em seus assentamento humanos. A idéia aqui enfatiza a necessidade de adequação tecnológica dos assentamentos conforme a necessidade de sua comunidade, desenvolvendo uma relação mais ampla entre a adequação do ambiente urbano aos meios naturais - implantações e recursos disponíveis.

Com a categoria 5 - 'Infra-estrutura viária' propõe-se analisar a constituição de cidades mais equilibradas em termos de ocupação e moradia, sendo acessibilidade pertinente e estabelecida tanto pelo Habitat I quanto pela Declaração do Milênio.

As categorias 6 - 'Existência de áreas verdes suficientes ao exercício das atividades de lazer' e 7 - 'Adequação quanto à concentração humana' se referem 
principalmente ao Habitat I, mas são vistos também na Agenda 21 e na Declaração do Milênio. Sua importância é bastante clara para termos de análise de uma configuração espacial urbana, na qual é necessária a tanto a presença de áreas para lazer e recreação da população quanto uma densidade que proporcione um relacionamento saudável entre os indivíduos.

Estas categorias e respectivos indicadores aqui apresentados foram considerados de grande relevantes para averiguar a qualidade do ambiente urbano, por isto, devem balizar tanto a classificação dos ambientes da cidade quanto o direcionamento de políticas urbanas para melhoria dos mesmos.

\subsubsection{Matriz de Indicadores de Qualidade de Vida Urbana - origem dos dados}

$\mathrm{Na}$ coleta de dados alguns itens foram retirados dos Censos Populacionais do Brasil para os anos de 1960, 1970, 1980, 1990 e 2000. O que motiva a utilização destes períodos para análise vem da incidência das políticas urbanas federais analisadas neste trabalho ocorrerem nos anos de 1970 e 1980. A observação do período imediatamente anterior permite compreender como era o município antes da interferência das políticas, o que permite avaliar se após sua introdução ocorreu desenvolvimento atrelado à sua locação de recursos.

$\mathrm{Na}$ tentativa de analisar as modificação decorrentes das políticas públicas analisa-se o Censo de 1990 na tentativa de abordar a modificação após transcorrido o período de instalação das obras e infra-estruturas decorrentes dos investimentos das políticas. Não há como associar exclusivamente o resultado encontrado nos dados às políticas urbanas federais e municipais, pois sabe-se que o poder público municipal contrai a miúde alguns investimentos destinados a esses fins. Mas a análise destes dados acrescida das informações sobre o desenvolvimento urbano 
das cidades obtida em documentos da prefeitura e demais bibliografias permite uma relação entre os fatos.

A pesquisa sobre o Censo de 2000 teve grande parte dos dados obtidos pelas tabelas do programa Sistema IBGE de Recuperação Automática (SIDRA), que é um banco de dados do IBGE, como é destacado no Quadro 5 - Matriz de Indicadores de Qualidade de Vida Urbana - origem dos dados.

Para fins da análise aqui realizada foram consideradas sempre as famílias e/ou os domicílios, sendo dada prioridade à informação sobre domicílios, que ocorre de maneira mais freqüente nos dados do IBGE.

O indicador 'Percentual de população acima do limiar da pobreza' substituiu o 'Percentual de população pobre' uma vez que estão sendo evidenciados na matriz elaborada as características gerais da população e não da exceção. Da primeira forma, a leitura da matriz teria seu entendimento prejudicado, pois analisaria parte do todo e não o próprio universo. Para efetuar tal ajuste, foi primeiramente calculada a população pobre da cidade que seria aquela que tivesse como renda per capita menos de dois dólares por dia. A partir daí, foram levantados os valores do dólar em relação às moedas brasileiras e o valor do salário mínimo de cada período de recenseamento, que pode ser visto no Apêndice deste trabalho.

Cabe sempre ressaltar que inúmeros dados alencados como necessários à composição da matriz não tiveram como fazer parte de sua aplicação, por falta de precisão para sua análise. Por exemplo, o resultado do Censo para algumas décadas apresenta o número de domicílios por aluguel. Poderia-se pensar que a subtração do número de domicílios total por estes, daria o número de domicílios próprios, o que não é o caso, pois existem também as figuras do 'domicílio cedido' e do 'outros' na metodologia do IBGE. 
Quadro 5 - $\quad$ Matriz de Indicadores de Qualidade de Vida Urbana - Origem dos dados

\begin{tabular}{|c|c|c|c|}
\hline Grupo & & Indicadores & Origem \\
\hline \multirow{2}{*}{$\begin{array}{l}\text { 1.Abastecimento } \\
\text { domiciliar de água }\end{array}$} & \multicolumn{2}{|c|}{ Acesso à água potável } & Tab 14367- IBGE \\
\hline & \multicolumn{2}{|c|}{ Proporções de domicílios com melhoria de acesso ao abastecimento de água } & \\
\hline \multirow{7}{*}{$\begin{array}{l}\text { 2.Saneamento } \\
\text { básico }\end{array}$} & \multicolumn{2}{|c|}{ Coleta de água servida } & Tab 14378- IBGE \\
\hline & \multicolumn{2}{|c|}{ Proporções de domicílios com melhoria de acesso ao saneamento } & \\
\hline & \multicolumn{2}{|c|}{ Proporções de domicílios com melhoria de acesso às instalações sanitárias } & \\
\hline & \multicolumn{2}{|c|}{ Águas residuais tratadas } & \\
\hline & \multicolumn{2}{|c|}{ Recolhimento regular de dejetos sólidos } & Tab 14399- IBGE \\
\hline & \multicolumn{2}{|c|}{ Adequada disposição do lixo } & \\
\hline & \multicolumn{2}{|c|}{$\begin{array}{l}\text { Promoção integrada de infra-estrutura ambiental: água, saneamento, drenagem } \\
\text { e manejo de resíduos sólidos }\end{array}$} & \\
\hline \multirow{10}{*}{ 3.Habitação } & \multicolumn{2}{|c|}{ Percentual de população pobre } & Tab 23810- IBGE \\
\hline & \multirow{2}{*}{ Densidade } & Área suficiente para viver & \\
\hline & & Proporção de domicílios com menos de três pessoas por cômodo & Tab 241811. IBGE \\
\hline & \multirow{3}{*}{ Benfeitoria } & $\begin{array}{l}\text { Utilização materiais permanentes que propiciem uma habitação } \\
\text { segura e duradoura }\end{array}$ & \\
\hline & & Conexões hidro-sanitárias internas ao domicílio & Tab 143812- IBGE \\
\hline & & Construída fora de áreas de risco & \\
\hline & \multirow{4}{*}{ Posse } & Habitação cuja ocupação esteja assegurada & Tab $1435^{13}$ - IBGE \\
\hline & & Financiamento de habitações & \\
\hline & & Relação preço da terra versus ingresso no mercado de terra & \\
\hline & & $\begin{array}{l}\text { Preço da habitação e coeficiente de habitações acrescidas no } \\
\text { montante total }\end{array}$ & \\
\hline \multirow{5}{*}{$\begin{array}{l}\text { 4.Desenvolvimento } \\
\text { técnico-tecnológico }\end{array}$} & \multicolumn{2}{|c|}{ Aperfeiçoados o manejo dos assentamentos humanos } & \\
\hline & \multicolumn{2}{|c|}{ Sistemas sustentáveis de energia e transporte nos assentamentos humanos } & \\
\hline & \multicolumn{2}{|c|}{ Prevenção de desastres e instrumentos de mitigação } & \\
\hline & \multicolumn{2}{|c|}{ Atividades sustentáveis na indústria da construção } & \\
\hline & \multicolumn{2}{|c|}{ Capacitação institucional e técnica para o avanço dos assentamentos humanos } & \\
\hline \multirow{2}{*}{$\begin{array}{l}\text { 5.Infra-estrutura } \\
\text { viária }\end{array}$} & \multicolumn{2}{|c|}{ Modos de transporte } & \\
\hline & \multicolumn{2}{|c|}{ Sistemas sustentáveis de transporte } & \\
\hline \multirow{2}{*}{\multicolumn{3}{|c|}{$\begin{array}{l}\text { 6.Existência de áreas verdes suficientes ao exercício das atividades de lazer } \\
\text { 7.Adequacão quanto à concentracão humana- Densidade populacão/ área urbanizada }\end{array}$}} & \\
\hline & & & \\
\hline
\end{tabular}

7 A Tabela 1436 - 'Domicílios particulares permanentes e Moradores em domicílios particulares permanentes por situação e tipo de abastecimento de água' permite a conclusão do dado de quais são os domicílios ligados à rede geral de distribuição de água.

8 A Tabela 1436 - 'Domicílios particulares permanentes e Moradores em domicílios particulares permanentes por situação e tipo de esgotamento sanitário' permite a conclusão do dado de quais são os domićlios ligados à rede geral de coleta de água servida.

9 A Tabela 1439 - 'Domicílios particulares permanentes e Moradores em domicílios particulares permanentes por situação e destino do lixo' permite 0 conhecimento do dado relativo à de coleta de lixo.

10 Para o cálculo da população pobre da cidade foi considerado o valor do Dólar em maio de 2000, sendo U\$1,826 em relação ao Real. Considerando que estão no limiar da pobreza aquelas pessoas que tem menos de dois dólares para viver por dia, no prazo de 30 dias - o equivalente a um mês - elas teriam que ter no mínimo R\$54,78 em 2000. O valor do salário mínimo em maio de 2000 era $\mathrm{R} \$ 151,00$. Uma pessoa que recebesse menos de $36 \%$ do salário mínimo, estaria abaixo da linha da pobreza. Foi consultada a Tabela 238 - 'Famílias residentes em domicílios particulares por classes de rendimento nominal familiar per capitã e tipo de composição familiar' sendo considerada a soma das famílias que recebiam até $1 / 2$ salário mínimo para a análise. Para os demais anos de análise, foi construído o mesmo raciocínio.

11 A Tabela 2418 - 'Domicílios particulares permanentes e Moradores em domicílios particulares permanentes por situação do domicílio e densidade de moradores por dormitório' permite a adequação à densidade do domicílio. Este dado é apresentado para alguns períodos apenas.

12 A Tabela 1438 - 'Domicílios particulares permanentes e Moradores em domicílios particulares permanentes por situação e número de banheiros', permite a conclusão do número de domicílios com acesso a conexões hidro-sanitárias. Este dado é apresentado para alguns períodos apenas.

13 A Tabela 1435 - 'Domicílios particulares permanentes e Moradores em domicílios particulares permanentes por situação e condição de ocupação do domicílio' permite que sejam vistos quantos são domicílios próprios, ou seja, cuja posse é assegurada. 
Nas formas de análise ocorridas pelo tempo ocorre alguma alteração na regionalização das unidades federativas. Em 1960, o IBGE tinha como universo de amostragem os estados divididos em unidades regionais denominadas Zonas Fisiográficas. Para 1970, passam a existir as micro-regiões. Para o estudo aqui disposto, Poços de Caldas integrava a microrregião de Planalto de Poços de Caldas, que no período anterior, integrava a Zona Fisiográfica do Sul de Minas. Já em 1990, Governador Valadares passa a integrar a Meso-região Mata e Rio Doce Mineiro, quando anteriormente, no Censo de 1980, a meso-região abrangia somente a região do Vale do Rio Doce. Já Juiz de Fora, que até 1990 integrava a Zona da Mata, passa a integrar o Centro Leste Mineiro.

No Quadro 5 é evidenciada a origem de cada dado atribuído aos indicadores. As tabelas do IBGE encontram-se no Anexo deste trabalho.

\subsubsection{Matriz de Indicadores de Qualidade de Vida Urbana - Matriz Tonal}

Como proposto anteriormente, a matriz será trabalhada com classes de valoração tonal que possibilitem a leitura e associação entre os dados. Tais variações foram assim definidas em classes:

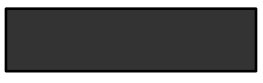

De $0 \%$ a $25 \%$ - $\quad$ indicação de baixa qualidade de ambiente urbano

De $26 \%$ a $50 \%$ - indicação de média a baixa qualidade de ambiente urbano

De $51 \%$ a $75 \%$ - indicação de média a adequada qualidade de ambiente urbano

De $76 \%$ a $100 \%$ - indicação de adequada qualidade de ambiente urbano
} 
A matriz aqui desenvolvida busca evidenciar a qualidade do ambiente urbano. Para tal, as cores mais suaves representam um ambiente mais próximo ao considerado 'sustentável'. Gradativamente, numa escala descendente, as tonalidades vão se tornando mais escuras na medida em que a situação de análise é menos desejável. Assim sendo, um município que possua 100\% da sua população atendida por um indicador terá uma tonalidade próxima ao branco. Já uma cidade com forte desequilíbrio do ambiente urbano, terá uma tonalidade marcada pela presença marcante do preto.

\subsection{DESENVOLVIMENTO DO TRABALHO}

A tese foi desenvolvida contando com uma introdução, quatro capítulos e conclusão.

O Segundo capítulo foi intitulado 'Políticas Públicas e Desenvolvimento', tendo no seu conteúdo as partes concernentes ao desenvolvimento urbano e regional do estado de Minas Gerais, a discrição dos PNDs e a ação do PNCCPM e do PROECI, além de uma análise da política urbana no Brasil.

O terceiro capítulo foi intitulado 'Sustentabilidade urbana: conceituação e abrangência'. Nele foi feita uma abordagem da ampliação da discussão ambiental em níveis mundiais através da apresentação das análises dos textos das Conferências Internacionais sobre Meio Ambiente e Assentamentos Humanos da ONU, tendo como objetivo a definição daquilo que seria 'sustentabilidade' e sua aplicabilidade para o ambiente urbano.

O quarto capítulo intitulado: "Estudo de Caso: O efeito das políticas Públicas nos Municípios" refere-se ao objeto de estudo deste trabalho, procurando fazer uma caracterização detalhada dos municípios escolhidos, no que se refere à 
caracterização dos recursos e estruturas obtidos pela ação dos planos nacionais e estaduais e o rebatimento da realidade pesquisada com a matriz conceitual formatada neste trabalho.

A Conclusão procura compilar as conclusões de todos os capítulos, discorrendo sobre a pertinência da hipótese colocada e quanto à própria estrutura do trabalho. 
2 POLÍTICAS PÚBLICAS E DESENVOLVIMENTO 


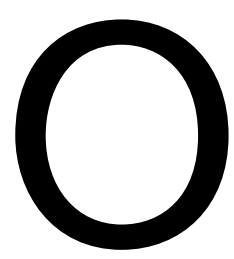

surgimento das políticas urbanas ou ao menos, a necessidade que encaminha ao seu surgimento, deve considerar que o ambiente urbano consiste no espaço da interação entre diversos atores e políticas. No dizer de Grinover (FAUUSP, 1984) para que se dê o processo de urbanização devem ocorrer relações entre economia, espaço, sociedade e meio ambiente. Assim sendo, o processo de urbanização não se explica por si mesmo.

Outra premissa exposta pelo autor é a de que tal processo - o da urbanização - não ocorre de forma homogênea sobre o espaço. Esta segunda premissa traz a necessidade de elaboração e aplicação das políticas urbanas: a da existência de distorções de crescimento entre as diversas partes do espaço urbano.

\subsection{O crescimento da população brasileira}

O processo de crescimento da população brasileira sofre uma inflexão drástica a partir dos anos 1940. Um dos motivos deste grande movimento pode ser considerado os fatos econômicos que propiciaram o chamado período dos "Trinta Gloriosos".

Trinta anos de crescimento econômico sem antecedentes na história do país, motivados primordialmente pela substituição de exportações advinda com o fim da Segunda Grande Guerra, um grande impulso econômico e uma representativa modificação na estrutura industrial brasileira.

Como resultado deste incremento produtivo, as cidades intensificam seu processo de crescimento. E a partir daí, passaram a atrair contingentes de população. 
Quadro 6 - População Urbana no Brasil

\begin{tabular}{|l|c|c|}
\hline \multicolumn{1}{|c|}{ Anos } & População Urbana (absoluto) & População urbana (percentual) \\
\hline 1940 & 12.775 .198 & 31,24 \\
\hline 1950 & 18.775 .198 & 36,16 \\
\hline 1960 & 31.955 .633 & 45,08 \\
\hline 1970 & 52.904 .744 & 55,98 \\
\hline 1980 & 80.437 .327 & 67,59 \\
\hline 1990 & 110.990 .990 & 75,59 \\
\hline 2000 & 137.925 .238 & 81,19 \\
\hline
\end{tabular}

FONTE: IBGE

Em 30 anos de urbanização - de 1940 a 1970 - a população urbana quase dobrou sua participação na população total, saindo de $31,24 \%$ para $55,98 \%$. De 1950 a 1960, a população urbana cresceu cerca de 70\% e de 1960 a 1970, cerca de $65 \%$, acumulando população em cidades novas mas principalmente, no aumento do tamanho de população das cidades (FRANCISCONI; SOUZA, 1976).

As classes de cidades que mais cresceram foram as de mais de 250 mil habitantes, o que revelava uma caracterização de concentração da população em grandes núcleos e aponta para a formação de regiões metropolitanas.

Mas ao mesmo tempo, não eram apenas as metrópoles que estavam crescendo:

(...) o processo de urbanização do Brasil estava assumindo proporções extraordinárias, de carácter explosivo. Não se tratava mais da expansão de uma ou de algumas metrópoles mas da urbanização em massa de um país populoso. (REIS, 1996:5)

Tendo sido o último quartel do século XX o período de maior crescimento tanto em números absolutos quanto relativos da população brasileira, era de se esperar que os déficits se tornassem mais evidentes em todos os aspectos compositivos do ambiente urbano.

Não apenas a carência de infra-estrutura para dar suporte à vida urbana, mas a ausência de estruturas geradoras de empregos e de acesso a terra, foram determinantes para a geração de grupos espaciais tanto entre as diversas regiões do país, quanto internamente ao ambiente das cidades. 
Neste contexto será analisado, o ambiente urbano no país que será alvo de planos nacionais de desenvolvimento que são analisados a seguir, estando coerentes ao recorte temporal adotado por este trabalho.

\subsection{A política urbana do Regime Centralizador}

Para fins deste trabalho, foram selecionadas principais políticas públicas urbanas neste período, visto que as demais políticas atuam no sistema urbano, mesmo que não o tenham como objeto. A atuação destas políticas compreendidas é contemporânea ao recrudescimento das questões ambientais em âmbito mundial, sendo este fato determinante para a escolha destas dentre as demais, como foi salientado neste trabalho, no item 1 - Introdução.

O primeiro documento a ser analisada foi a do I PND, que foi estabelecido pelo governo federal para as ações compreendidas no período de 1972 a 1974.

O I PND ${ }^{14}$ apresenta uma proposta para modernização das realizações nacionais através do estabelecimento de processos competitivos e processos de integração. Para que estes processos competitivos e de integração pudessem se realizar, faziam-se necessários incentivos que possibilitassem um aumento na eficiência tanto do setor público quanto nos setores privados. Buscava-se a modernização da empresa nacional, seja ela pública ou privada.

No setor público, evidencia-se a necessidade da integração nacional, que deveria ser objetivada com a consolidação do desenvolvimento do Centro-Sul e a criação das regiões metropolitanas. Buscava-se a criação de empresas de grande porte, efetivadas através de grandes programas de investimento. A empresa

\footnotetext{
${ }^{14}$ De redação panfletária, no texto da Lei, o Governo do General Emílio Garrastazu Médici é denominado de "Terceiro Governo da Revolução". Os anos do governo Médici foram os mais duros da ditadura brasileira, tendo sido reprimidas as formas de organização sociais oponentes ao governo militar.
} 
brasileira deveria ser dinamizada com a implementação de uma política tecnológica nacional, na qual deveria ocorrer tanto a transferência de tecnologia quanto a elaboração de tecnologia própria.

Ocorre uma ampliação dos programas de integração social, com o Programa de Integração Social (PIS), o Programa de Formação do Patrimônio do Servidor Público (PASEP) e o Programa de Assistência ao Trabalhador Rural (PRO-RURAL).

Segundo apresentado no texto, o "Segundo Governo da Revolução"15 teria tido como objetivo a expansão econômica acelerada, impulsionada pela expansão industrial. A idéia norteadora deste Terceiro Governo da Revolução, que tem aqui sua política de desenvolvimento analisada, era da ampliação do mercando interno para expansão da economia.

Os mercados do Nordeste, Centro-Oeste e da Amazônia eram os que mais dependiam os maiores esforços no sentido da integração, devido à baixa divisão social de trabalho então existente, que dificultava a ampliação do pretendido mercado interno para expansão econômica.

Deve ser compreendido que para ocorrer tal ampliação do mercado interno e a integração nacional proposta pelo IPND, as medidas propostas para ampliação da "sociedade urbana" no conjunto das práticas sociais da nação. Cabe ressaltar, que a sociedade não se encontrava homogeneamente distribuída, uma vez que parcelas da sociedade brasileira ainda viviam - e vivem até o presente momento - distantes dos parâmetros desta sociedade. (MELLO; NOVAIS, 1998).

A sociedade brasileira vivia em estágios distintos de inserção ao modo urbano de produção. Segundo Lefebvre (1999) o urbano introduz novas formas de

\footnotetext{
15 O "Segundo Governo Militar", que antecede o do General Garrastazu Médici, foi em parte presidido pelo General Costa e Silva, que em 1969 adoeceu gravemente, ficando impossibilitado de exercer suas funções. A Constituição previa a transferência do poder para o vice-presidente, Pedro Aleixo. No entanto, desobedecendo a lei, assumiu o governo uma junta composta pelos ministros militares; Augusto de Hamann Kademaker Grünewald (Marinha), Aurélio de Lira Tavares (Exército) e Márcio de Souza e Melo (Aeronáutica).
} 
relação com a produção e o consumo que são distintas daquelas colocadas pela indústria. O consumo de bens e a necessidade de ampliação do mercado interno para que ele se dê, é afeto à revolução urbana ${ }^{16}$.

Mas ao mesmo tempo, a visão do IPND buscava ser ampla, assumindo a necessidade da criação de grandes empresas e programas, como o programa de Expansão da Siderurgia, Programa Petroquímica, implantação dos corredores de Transportes, o programa de Construção Naval, o Programa Básico de Energia Elétrica para dar suporte à ampliação da indústria nacional através da criação de indústrias de base, de transformação e de criação de infra-estrutura.

Conforme o IPND, todas estas estruturas estariam associadas a organizações humanas preexistentes, reforçando a centralidade dos núcleos urbanos, ainda que o discurso apregoasse uma "descentralização" nacional progressiva em nome da integração social: “(...) Por outro lado, o Centro-Sul continuará, como é natural, a absorver a maior parcela do capital físico do País em equipamentos, instalações e edificações, tanto na Indústria, quanto na Agricultura." (BRASIL, 1971, p. 26).

Quanto à transformação da economia rural, que ocorreria pela modernização da agricultura para "sustentar o processo industrial" (BRASIL, 1971), existia o conhecimento de que fazia-se necessária uma retenção do homem na terra principalmente o nordestino - uma vez que:

(...) a indústria, geradora de renda urbana e modificadora dos demais setores, não solucionará, por si só, o problema do emprego. Com o ritmo atual de migrações, agravar-se-á o subemprego urbano, pois, na década de 60 , a população urbana cresceu a $6 \%$ ao ano, enquanto o emprego industrial aumentou apenas 1 a $2 \%$, anualmente. (BRASIL, 1971, p. 28).

\footnotetext{
${ }^{16}$ Segundo Lefebvre (1999), o urbano se amplia para além daquilo que seria a cidade, sendo um modo de vida, uma sociedade.
} 
O IPND colocava como sendo prioridades nacionais setoriais a aceleração do Programa de Saúde e Saneamento, revolução na Agricultura-Abastecimento e aceleração do desenvolvimento científico e tecnológico. (BRASIL, 1971, p. 41).

As ações setoriais, como as de Saneamento, expostas no texto do Plano, demonstravam um quadro existente muito ruim com previsões bastante otimistas de melhoria, mas que efetivamente deixavam muito a desejar. Considerando tais dados, o país contaria em 1972 com 100 milhões de habitantes, sendo o percentual de população vivendo na área urbana igual a 56\%. A população urbana servida com abastecimento de água estaria na ordem de 27 milhões, contra 13 milhões atendidos por Esgotamento Sanitário. A previsão de investimento do IPND para Abastecimento de Água estimava um aumento de $41 \%$, chegando a 38 milhões a população atendida e para o Esgoto, 43\%, chegando a 19 milhões de ligações. Tendo por referência a população estimada, tem-se $68 \%$ da população tendo abastecimento de água e menos de um terço da população total com serviço de esgotamento sanitário, o que era contemplado dentro do Plano como uma política setorial de Saúde.

A análise do IPND suprime qualquer dúvida que por ventura pudesse existir sobre o quadro dos problemas urbanos no país. Em primeiro lugar, a concentração de investimentos feitas no Sudeste fazia com que este polarizasse o restante do país, atraindo inegavelmente a migração. A taxa de crescimento dos empregos em indústrias não era elevada o suficiente para absorver a mão-de-obra disponível, ficando grande parte dela subempregada no setor terciário. Em seguida, o discurso sobre a desconcentração que aparece no texto da lei era dúbio, uma vez que esta continuava favorecendo a locação de investimentos para a região Sudeste, reforçando a concentração de indústrias e capital ai existente. 
Assim sendo, a migração continuaria se dando pela atração da população por empregos, que não eram gerados nas proporções necessárias por ela e que não a absorvia. Evidentemente isto levaria a uma pressão sobre a constituição do ambiente urbano, servido pela precariedade. Esta pode ser também reafirmada pela ausência de infra-estrutura urbana suficiente para a população urbana.

A predominância da população em concentrar-se nas áreas urbanas de maior porte foi evidenciada pela criação das regiões metropolitanas, cuja implantação e regulamentação ficaria a cargo da também criada Comissão Nacional de Regiões Metropolitanas e Política Urbana (CNPU).

Mais recentemente, o Governo criou a Comissão Nacional de
Regiões Metropolitanas e Política Urbana (CNPU) através do decreto
no 74.156 , de 06.6.1974, com a finalidade de traçar as diretrizes,
estabelecer a política e coordenar o processo de desenvolvimento
urbano no País. (BRASIL, 1975).

Segundo a análise exposta no documento, o fenômeno de ampliação das cidades e da população urbana foi naturalmente desencadeado pelo ao processo de substituições de importações. Como ressaltado anteriormente, no caso do Brasil, foram feitas primeiramente as substituições de importações dos bens de consumo durável de alto padrão e somente após o primeiro choque do petróleo em 1973, como o valor dos produtos importados tornourse muito elevado, fez-se necessário a substituição de importações de bens de produção e insumo.

A idéia da criação das grandes empresas nacionais visava aparelhar o país com industrialização de bens de base e de capital. Mas ao mesmo tempo, havia uma pressão para que se ampliasse o consumo de bens duráveis, numa tentativa de integração do consumo nacional.

Apontava-se então, em duas direções distintas, sendo uma a da necessidade de criação de uma indústria de base, simultaneamente a de ampliação 
do mercado de bens de consumo duráveis. Efetivamente, seria necessário o amadurecimento da primeira etapa, para o surgimento da segunda.

Segundo Singer (1977):

(...) o processo de desenvolvimento se inicia por uma ruptura estrutural, começando o Setor de Mercado Interno a crescer autonomamente, tornando-se competidor da indústria fornecedora de produtos importados, que ele passa a substituir, até se transformar no setor condutor de toda economia (SINGER, 1977, p. 15) (grifo do autor).

Assim sendo, para que haja crescimento econômico deve ocorrer uma ampliação de mercado interno. Para que ocorresse a ampliação do mercado de consumo foram então utilizados métodos persuasivos sobre a necessidade do consumo sobre as camadas 'menos integradas' ao ambiente do consumo ${ }^{17}$.

Já o II PND é considerado como um marco na política urbana no Brasil por ter contemplado um capítulo dedicado a esta. Ocorre uma preocupação com o ambiente urbano geral do país, ou seja, apesar das características locais de cada cidade, o ambiente urbano como um todo era caracterizado pelas mesmas deficiências, o que permitia que se vislumbrasse as questões estruturadoras desta realidade $^{18}$. Essa estrutura firmava-se no urbano, mas era na verdade, proporcionada pelos demais setores do desenvolvimento econômico.

O II PND começa reproduzindo o pronunciamento do Excelentíssimo Senhor Presidente da República, o senhor Ernesto Geisel, no qual o presidente faz menção à dificuldade de se planejar em meio a um mundo em crise - seja do sistema monetário internacional, seja de energia e matérias-primas, seja de inflação endêmica. As dimensões da crise do petróleo já podiam ser sentidas, trazendo para o discurso do planejamento o enfoque ambiental.

\footnotetext{
17 Sobre o poder de persuasão da mídia e das elites brasileiras para a ampliação do consumo de bens duráveis, ver: Piquet; Ribeiro, 1991.

18 Cabe aqui uma ressalva sobre o Plano Decenal de Desenvolvimento Econômico e Social, de 1967, que possuía também um tomo dedicado ao 'Desenvolvimento Regional e Urbano', mas que teve suas proposições subjugadas pela ênfase econômica dada ao desenvolvimento do país (MONTE-MÓR, 1981).
} 
No título do II PND, "Campos de atuação da Estratégia de Desenvolvimento" são enumeradas as necessidades prementes de atuação, estando entre elas: a) consolidação de uma economia moderna que incorpore novos setores e áreas das diversas regiões do país, para além da Centro-Sul; b) ajustamento à novas realidades da economia mundial no sentido de economizar energia e expandir novas fontes internas; c) nova etapa no esforço da integração nacional que seria uma ampla utilização econômica do espaço nacional, utilizando melhor os recursos humanos e o capital já investido para assegurar a continuidade do crescimento $^{19}$; d) estratégia de desenvolvimento social que pretendia garantir a todas as classes, em especial a classe dos trabalhadores, substanciais aumentos de renda e também eliminar, no menor prazo possível, os focos de pobreza absolutos existentes, principalmente do semi-árido do Nordeste e na periferia dos grandes centros urbanos; e) integração com a economia mundial.

Estas estratégias de atuação para o desenvolvimento centravam-se grandemente na idéia da ampliação do mercado como possibilidade de inserção das pessoas a economia, como pode ser visto no seguinte passagem do texto:

De um lado, procurar-se-á assegurar um mínimo de nível de bemestar universal, para que nenhuma classe fique fora do processo de integração e expansão. De outro lado, realizar-se-á esforço de estruturar, através do próprio processo de crescimento e do orçamento de desenvolvimento social, uma base substancial e rapidamente crescente de consumo de massa. (BRASIL, 1974, p. 35).

A nova etapa da integração nacional visava ampliação ou a incorporação das áreas mais remotas do país como um todo na lógica da produção e do consumo de massa, uma vez que muitas áreas ainda não se "integravam" a esta ordenação econômica.

\footnotetext{
${ }^{19}$ Cabe uma ressalva sobre o momento econômico de então. O país acabara de sair do momento do Milagre Brasileiro, passando a viver um momento de juros altos, inflação ampliada, diminuição do crescimento econômico do país de uma maneira geral.
} 
O desenvolvimento, na acepção do termo estabelece a ocorrência de uma mudança estrutural na ordem social. Os dois planos até agora expostos demonstram a intenção de proporcionar níveis satisfatórios de crescimento econômico ao país, de modo a inibir possíveis insatisfações sociais, uma vez que o pacto populista até então existente havia sido quebrado pela ditadura militar e o endurecimento do regime político. Mas não ocorreram mudanças estruturais na forma de distribuição de riquezas no país. Havia a necessidade de crescimento do país, feito através do desenvolvimento geral da sociedade e não apenas para absorção e integração com mercados de consumo mundiais.

Dentro da lógica de crescimento estabelecida no II PND, fazia-se necessária a desconcentração do mercado existente marcadamente ou primordialmente no eixo Centro-Sul. As diversas áreas do país formam zoneadas de acordo com uma diretriz de expansão ou restrição ao crescimento, como pode ser visto no mapa 5 - Política Nacional de Desenvolvimento Urbano.

Os estados de grande crescimento demográfico no ultimo quartel do período analisado - 1930/1970, como seria o caso dos estados da Guanabara e do Estado de São Paulo, somados a eles as cidades componentes de suas regiões metropolitanas no entorno da capital - a Grande Rio, a Grande São Paulo acrescidas das regiões metropolitanas de Belo Horizonte e Vitória, sofreriam a chamada "disciplina e dinamização". O uso do termo, pelo indicado no texto, diz respeito a uma dinamização que possa otimizar o investimento de recursos já feitos neste trecho do território nacional, ao mesmo tempo em que permitiria a contenção do investimento neste mesmo lugar, fazendo parte da estratégia de “desconcentração”. 


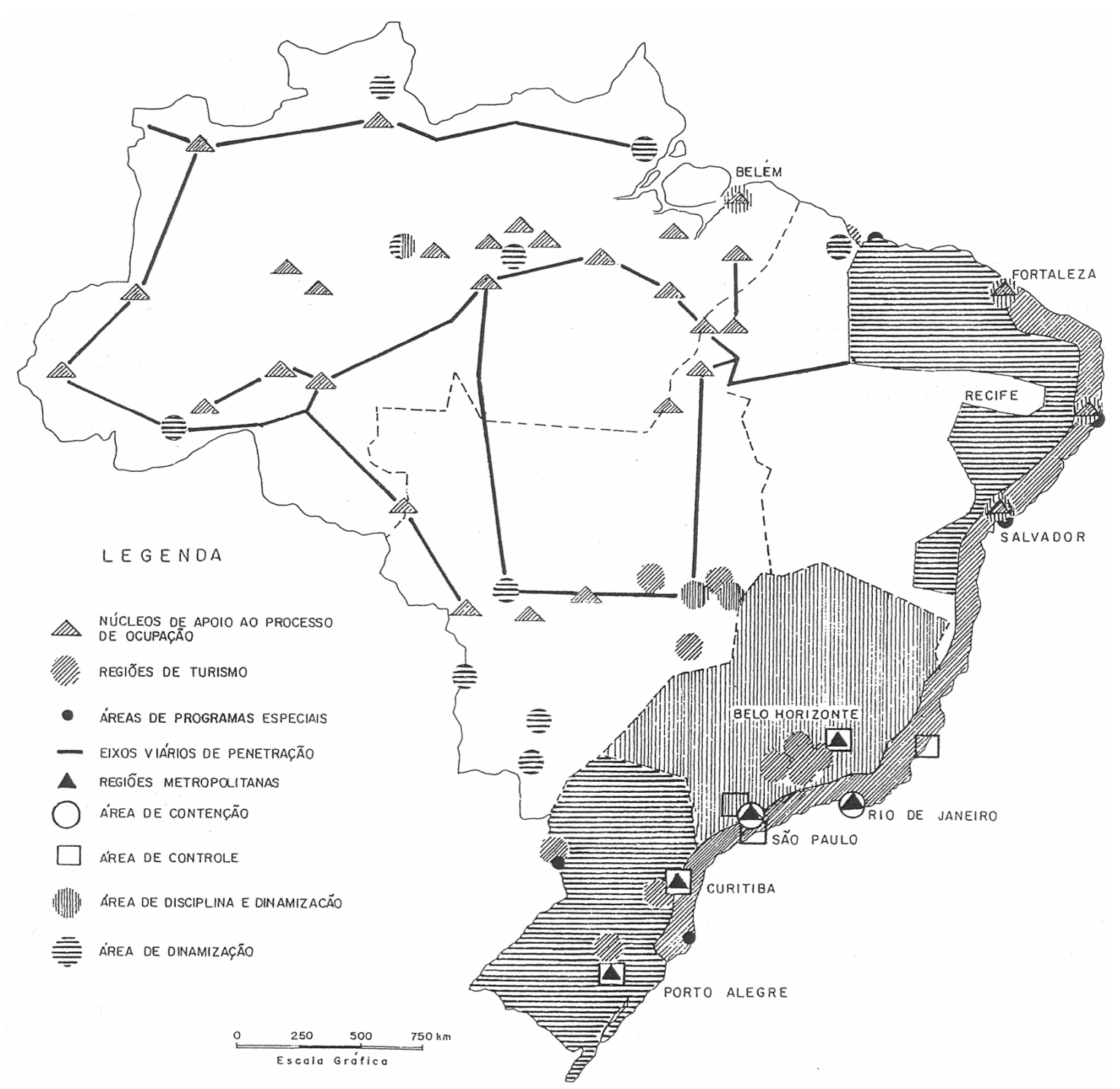

Mapa 5 - $\quad$ Política Nacional de Desenvolvimento Urbano (PNDU), 1975-1979. FONTE: BRASIL, 1975.

A região Sul do país e trechos da Nordeste estariam em uma área de dinamização das atividades, numa busca da integração nacional, assim como também os "eixos viários de penetração", ao se articularem com os núcleos de apoio ao processo de ocupação.

Como parte componente do II PND, o Ministério do Interior divulgou o 'Programa de Ação do Governo na Área de Desenvolvimento Urbano - 1975/1979', que tratava de um desenvolvimento mais detalhado da Política Urbana proposta pelo primeiro documento. Sendo assim, o Programa buscava fazer uma caracterização 
do fenômeno urbano no Brasil. Para tal caracterização, relata o surgimento do planejamento urbano como ocorrido a partir dos anos 60, apoiado em esparsas experiências do passado.

$\mathrm{Na}$ verdade, o processo de planejamento tem seu surgimento por volta dos anos trinta, quando das experiências dos planejamentos municipais, voltados ao direcionamento dos municípios - planos diretores municipais - no Rio Grande do Sul.

Nessa mesma época ocorreram outras experiências que merecem registro como a da Sociedade de Análises Gráficas e Mecanográficas Aplicadas aos Complexos Sociais (SAGMACS), que realizou estudos e planos para as cidades de São Paulo, Recife, Belo Horizonte, dentre outras.

Décadas mais tarde, teria início a discussão da reforma urbana, ampliada no Seminário de Habitação e Reforma Urbano sediado em Petrópolis, em 1964.

Em 1964, com a criação do Banco Nacional de Habitação (BNH) e do Serviço Federal de Habitação e Urbanismo (SERFHAU), ampliavam-se as intenções de abordagem das questões urbanas ${ }^{20}$.

O 'Programa de Ação do Governo na área de Desenvolvimento Urbano’ foi dividido em seis capítulos e propunha tanto a dar embasamento às ações que seriam contempladas pela política urbana quanto à exposição do próprio plano de ação de tal política.

Tomando por base o crescimento das metrópoles nacionais - Rio de Janeiro e São Paulo - o programa apontava para a premência da descentralização das atividades visando à integração nacional de mercado produtor e consumidor. A população encontrava-se mal distribuída no território nacional, o que era em parte devido a uma grande centralização de funções urbanas nas capitais nacionais e 
regionais e que desencadeava em um círculo vicioso no qual as mesmas cidades eram reiteradas vezes absorvedoras das estruturas urbanas que acabavam se sobrepondo ao invés de estarem disseminadas pelo espaço nacional, possibilitando uma melhor hierarquia e consumo das atividades existentes nas ditas cidades.

No intento de fortalecer e melhor estruturar o sistema urbano brasileiro foram criados diversos organismos e programas: Departamento Nacional de Obras de Saneamento (DNOS); Secretaria Especial do Meio Ambiente (SEMA), SUDENE, Superintendência do Desenvolvimento da Amazônia (SUDAM), Superintendência de Desenvolvimento do Centro-Oeste (SUDECO), Superintendência do Desenvolvimento da Região Sul (SUDESUL) e Projeto Rondon.

O capítulo 5 do texto do II PND, intitulado "Política Nacional de Desenvolvimento Urbano" expõe a seguinte determinação:

Reconhecidos os grandes contrastes existentes entre as cidades que integram o sistema urbano nacional, em termos de dimensão das unidades urbanas, dos padrões de sua distribuição espacial, dos níveis de equipamentos e das funções que desempenham, a Política de Desenvolvimento Urbano a ser posta em execução deverá basicamente promover o fortalecimento e a melhor estruturação do sistema urbano do País e respectivos subsistemas regionais, visando a adequar seu funcionamento à consecução dos grandes objetivos nacionais. (BRASIL, 1975, p. 73).

Colocados acima os objetivos gerais, era enfatizada a necessidade de fortalecimento e melhor estruturação do sistema urbano nacional e dos subsistemas regionais, com "vistas à redução dos desequilíbrios existentes, à maior eficácia no desempenho das funções urbanas e à elevação dos padrões de urbanização e de qualidade de vida urbana" (BRASIL, 1974).

Muitos dos objetivos específicos estão ligados a uma melhor ocupação das regiões Norte e Nordeste do país além de uma preocupação em "patrocinar a realização de estudos e projetos de interesse do desenvolvimento urbano, em colaboração com governos estaduais e administrações municipais" (BRASIL, 1974). 
As estratégia e diretrizes para o desenvolvimento urbano traziam à tona a necessidade de que a integração nacional ocorresse contribuindo para a "redução das desigualdades inter e intra-regionais e para a ordenação e a expansão do processo de ocupação produtiva do território brasileiro". (BRASIL, 1974, p. 75). A definição de uma estrutura urbana almejada nacionalmente, concebida de forma integrada com os programas de desenvolvimento nacionais e regionais seria viabilizada através da promoção de uma estruturação do sistema urbano focalizando na eficácia das "funções exercidas pelas cidades e à elevação dos padrões de urbanização e qualidade de vida." (BRASIL, 1974, p. 75).

A necessidade de uma desconcentração das atividades econômicas geradoras de urbanização, particularmente das indústrias, apontava a necessidade da regulamentação do uso do solo. Devido a esta necessidade foram criados programas de pós-graduação na Área de Planejamento Urbano e Regional, visando capacitação dos funcionários do poder executivo que poderiam agir de forma coordenada com esta orientação ordenadora do planejamento e da cidade.

Como órgão coordenador da Política Nacional de Desenvolvimento Urbano (PNDU) e para acompanhar a implantação das recém-criadas regiões metropolitanas havia sido criada a Comissão Nacional de Regiões Metropolitanas e Políticas Urbanas (CNPU), sendo o Ministério do Interior a pasta que recolhia para sua responsabilidade o desenvolvimento urbano. Suas ações deveriam ser contempladas nas áreas de habitação, urbanismo, transporte urbano, abastecimento de água, esgotos sanitários equipamentos comunitários, combates à poluição, preservação ambiental, construção de obras contra inundações, assistência a populações afetadas pelas calamidades públicas, orientação dos migrantes nos centros urbanos. (BRASL, 1975). 
A programação existente para a viabilidade do programa foi apresentada como sendo o $\mathrm{BNH}$ o banco gestor de programas diversos nos variados setores conformadores do espaço urbano.

Entre eles deve ser citado o Plano Nacional de Saneamento (PLANASA), que deveria ser devidamente consolidado no período de 1975-79, ampliando em $80 \%$ o abastecimento de água em todo o país, atendendo com serviços de esgoto mais simples as áreas mais pobres e intensificando os Programas Estaduais de Controle da Poluição (PECON).

Além do PLANASA, estendia-se o programa de Financiamento de Urbanização e Equipamentos Comunitários, visando ampliação dos serviços de infra-estrutura para as novas áreas ampliadas pelo crescimento urbano, além de propor o melhor aproveitamento de áreas com capacidade ociosa. Os serviços urbanos deveriam promover o adensamento de áreas nas quais os efeitos da especulação imobiliária ocorriam de forma danosa. (BRASIL, 1974, p. 81).

O Projeto Comunidade Urbana para Renovação Acelerada (Projeto CURA) tinha especial importância na dinamização das questões de planejamento intraurbano, tais como instituição de alíquotas de imposto territorial urbano, fixação de taxas de ocupação do solo, legislação de parcelamento de solo, dentre outras. Já para a recuperação de áreas em estado de obsolescência fora criado o Projeto de Renovação Urbana.

Outro programa de destaque era o Programa de Transportes Urbanos que deveria auxiliar a organização das áreas urbanas, através da ampliação da mobilidade sobre ela e da distribuição da valorização da terra pelo seu acesso.

Diversos outros programas compunha o Programa, tais como aqueles praticados pelo Departamento Nacional de Obras de Saneamento (DNOS), que se articulava com o PLANASA, na recuperação de vales e controle de enchentes. 
Todas as proposições do PNDU estavam embasadas na caracterização dos sistemas urbanos regionais.

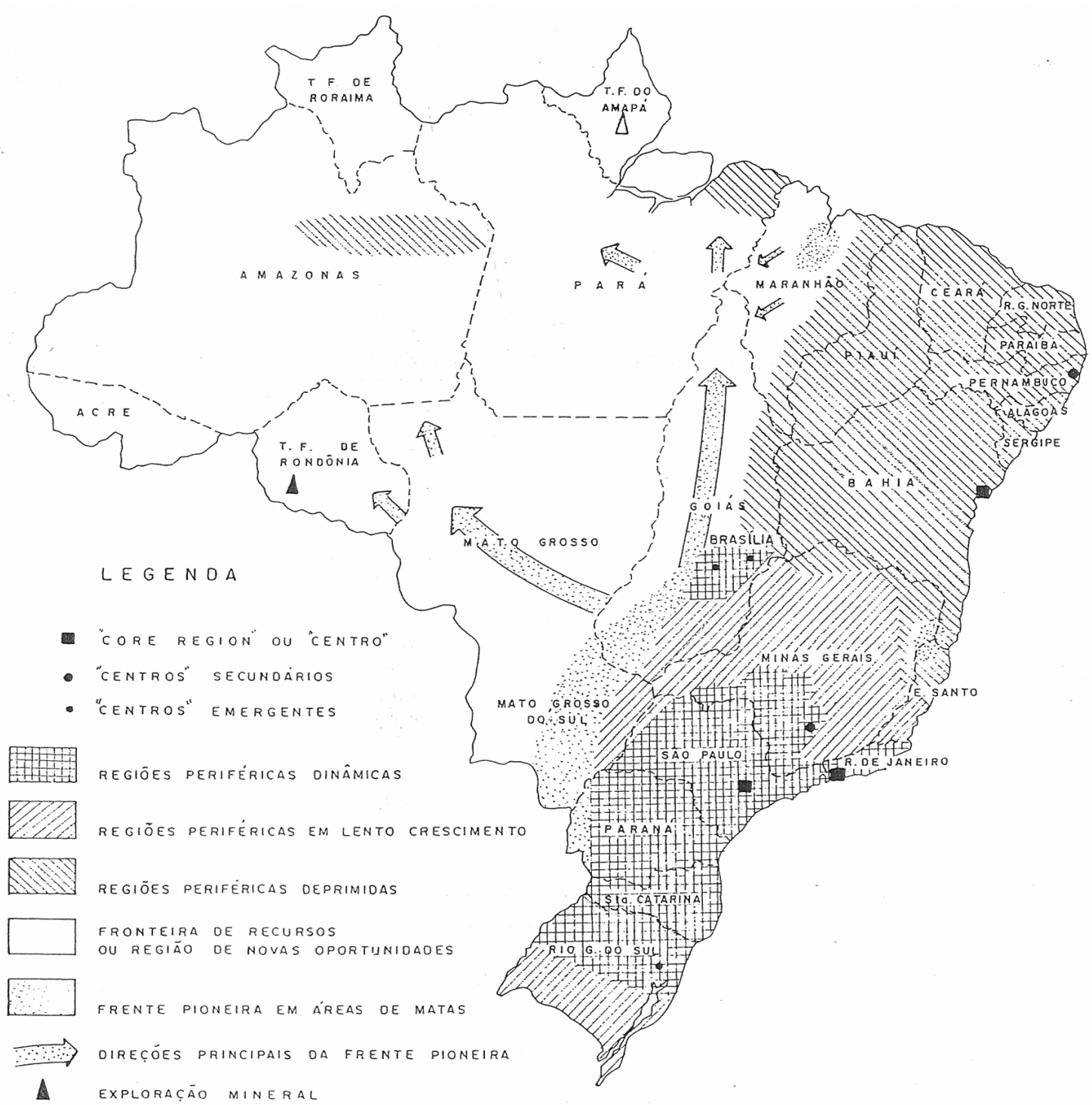

Mapa 6 - Tipos de regiões segundo interações espaciais, 1970.

FONTE: BRASIL, 1975.

$\mathrm{Na}$ interpretação do mapa, o core region ou centro da estrutura urbana brasileira de então era representado pelo eixo São Paulo/Rio de Janeiro. Segundo o texto, a drenagem dos investimentos feitos no referido centro, gerou o surgimento de outros centros intermediários na periferia, em decorrência do processo de substituição de importações verificadas no período anteriores. 
A Política Urbana adotada pelo II PND e detalhada no PNDU, tinha como finalidade o estabelecimento de diretrizes para a alcançar a estrutura urbana que se deseja estabelecer nacionalmente, concebida em função dos objetivos e programas de desenvolvimento nacionais e regionais.

A cidade deveria, então, situar-se dentro do planejamento do pólo econômico em que se encontra, definindo-se a sua função econômica e social e, só então, passando a definir-se sua configuração físico-urbanística. Freqüentemente, esse enfoque significará a reorientação das linhas mestras de expansão da cidade, geograficamente, solução que, no longo prazo, se afigura mais racional e menos dispendioso do que as simples soluções de engenharia que tomem como um dado as atuais tendências de evolução mecanicamente. (BRASIL, 1975, p. 87) (grifos nossos).

As idéias acima colocadas demonstram intenção de trabalhar com as redes ou sistemas urbanos na estruturação e hierarquização do espaço urbano, além de demonstrar uma clara intenção de ação no ambiente intra-urbano das cidades.

Podem ser retiradas no II PND as seguintes premissas norteadoras:

- Definição e reforço das funções a serem cumpridas pelas metrópoles nacionais;

- $\quad$ Definição de pólos regionais, ou metrópoles regionais;

- Desconcentração de investimentos, favorecendo, no entanto a região Sudeste - a chamada "desconcentração concentrada";

- $\quad$ Estabelecimento do uso do solo municipal;

- Definição e estabelecimento da estrutura urbana nacional.

Segundo Amorim Filho e Serra (2001), a temática das cidades médias vinha sendo desenvolvida pelos planejadores franceses desde o fim da Segunda Grande Guerra, sobretudo a partir dos anos 50 . Os estudos das chamadas 'metrópoles 
regionais' seriam de grande contribuição para o planejamento urbano na década de 70. Na raiz do tema cidades médias estaria a necessidade de equilíbrio regional ou de darem-se soluções aos desequilíbrios urbano -regionais.

Segundo o referido autor, a década de 70 remonta aos anos 50, quando surge uma nova modalidade de planificação: o aménagement du territoire, que seria uma "reflexão sobre a procura de uma distribuição mais equilibrada das atividades, das riquezas e dos homens sobre o espaço nacional e regional." (AMORIM FILHO; SERRA, 2001, p. 6).

O III PND, atuação do governo para o período de 1980 a 1985, deu continuidade às ênfases necessidades determinadas pelos outros dois planos anteriores.

Sua estratégia apontava a necessidade da redução dos desequilíbrios sociais e apontava para a necessidade da redução das disparidades pessoais e regionais de renda. (BRASIL, 1980, p. 17).

Ressalta va que para a ordenação deste plano, os setores prioritários eram o da agricultura e abastecimento, o energético e o social. Neste sentido, procurava enumerar atitudes que visassem dar incentivo e escoamento à produção agrícola, ampliando portanto, tanto os setores de transportes, chamados de 'Corredores de Exportação e Abastecimento" quanto potencializando a distribuição espacial da população em cidades de porte médio.

O III PND reconhecia serem as demais políticas setoriais definidoras das dinâmicas sócio-espaciais e, na sua seção sobre Política Regional e Urbana teceu considerações sobre a necessidade tanto da integração permitida pela disseminação da estrutura urbana ao longo do território nacional, quanto pela da redução de disparidades que esta desconcentração poderia alcançar. 
Sendo contemporâneo do segundo choque do petróleo, o Plano procurava dar dimensões apropriadas para a crise energética e o pagamento dos juros das dívidas externas para contenção da inflação.

\subsection{O Programa Nacional de Cidades Médias}

A resolução 003 do CNPU estabelece quais são os objetivos do Programa Nacional de Cidades de Porte Médio: Propiciar a criação de novos pontos de desenvolvimento no território nacional; estimular a desconcentração de atividades econômicas e de população; promover a criação de novas oportunidades de emprego e de contribuir para a redução das disparidades inter-regionais e interpessoais de renda. (FAUUSP, 1984).

Serra (1991) expõe quais seriam os critérios para seleção das cidades. Foram determinados dois grandes grupos de critérios, sendo suas determinações feitas por recortes espaciais e intra-urbanos.

Os critérios espaciais dividiam-se em: relevância regional; localização em relação aos eixos principais; existência de programas especiais na área; distância de outras aglomerações ou centros e posição estratégica.

Os critérios intra-urbanos dividiam-se em: dimensões demográficas; desempenho econômico recente; grande proporção de migrantes recentes; pobreza urbana; grande proporção de migrantes recentes; estrutura do PEA e evolução urbana recente.

As ações do programa deixariam muito a desejar segundo avaliação feita em parceria com a Faculdade de Arquitetura e Urbanismo da Universidade de São 
Paulo (FAUUSP) e o $\mathrm{CNDU}^{21}$. Das conclusões obtidas por eles, salientam-se aquelas que dizem respeito à utilização de grande parte dos recursos advindos dos convênios estabelecidos com os municípios para a implantação de um sistema viário ou em investimentos do transporte urbano. O Fundo Nacional de Desenvolvimento Urbano (FNDU) favorecia o Fundo de Desenvolvimento de Transportes Urbanos (FNTU) com o montante $75 \%$ dos recursos dele provenientes e exigia a total alocação destes recursos no sistema viário ou de transportes.

Muitos municípios tiveram que destinar quase a totalidade de sua capacidade de investimentos em infra-estrutura viária, o que conduziu ao reforço do conceito de rede urbana.

A tendência ao comportamento do planejamento seguida por uma lógica de rede de cidades justifica a adoção da primazia para as infra-estruturas de transporte. A ideologia difundida era a de que se deveria "integrar" o país através do crescimento de sua economia. Para que o processo de integração pudesse ocorrer de fato, seria necessário que a integração física existisse e esta se daria através da articulação linear - vias - dos pontos da rede 22 .

\subsection{Programa Estadual de Centros Intermediários (PROECI)}

Com relação às necessidades expostas pelo Programa de Ação do Governo na área de desenvolvimento urbano, derivado do II PND, os governos dos estados

21 Em 2001, o presidente Fernando Henrique Cardoso reedita a CNDU, através da Medida Provisória n. 2.220, de 4 de sete mbro de 2001, que dispõe sobre a concessão de uso especial de que trata $0 \S 1^{\circ}$ do art. 183 da Constituição, cria 0 Conselho Nacional de Desenvolvimento Urbano (CNDU) e dá outras providências.

22 Segundo Matos (2005), uma análise demográfica pode ser metodologicamente executada através da análise dos nódulos ou pontos da rede. No trabalho em questão, o autor utiliza dados do IBGE de 1991 para análise de migrações no Brasil e o IBGE seleciona os pontos ou nódulos da rede através tanto de dados populacionais, quanto de articulações viárias que existem entre os pontos da rede. 
federados manifestaram-se de acordo com a necessidade de dar complementaridade ao Programa Nacional de Cidades de Porte Médio.

Sendo assim, o PROECl foi elaborado pela FJP a pedido do governo do estado de Minas Gerais. O que fundamenta a criação deste programa seria uma adequação do desenvolvimento segundo as políticas nacionais e as características próprias da realidade regional. No seu cerne, o programa procurou aumentar a fixação da população e a capacidade produtiva do estado.

A lógica que embasava a concepção do programa estava na eficiência de alocação dos recursos visando uma eficácia na sua aplicação. Por tal, o programa enfatiza a visão espacial da questão do planejamento urbano e regional. Neste sentido, via a necessidade de:

(...) distribuir os recursos concentrando-os geograficamente em áreas e centros urbanos prioritários para sustentar uma mudança na atual estrutura espacial e para alcançar os objetivos estaduais e nacionais. Esta diretriz básica do enfoque de planejamento regional, requer uma estratégia polarizada para a programação do desenvolvimento espacial, entendida como ação concentrada e coordenada nas áreas geográficas e centros urbanos prioritários.

Este enfoque sugere a necessidade de visualizar, em termos globais, o problema urbano-regional, de modo que se atue com referência a um sistema de cidades claramente hierarquizadas, conforme a área de influência e o nível de sua polarização nacional, regional ou microrregional. (FJP, 1980a).

Torna-se relevante ressaltar que o $\mathrm{PROECI}$ ao definir o "problema urbanoregional" fazia sua opção de concepção do processo de planejamento a ser implementado e conseqüentemente, de metodologia que a ele deveria prestar-se. Ao que pese "distribuir concentradamente" entre pontos do sistema urbano do estado de Minas Gerais, definidos pela análise da hierarquização urbana do estado $^{23}$, o programa visava acompanhar ou respeitar as determinações do II PND

\footnotetext{
${ }^{23}$ FJP. Fundação João Pinheiro. Estrutura espacial do estado de Minas Gerais. Belo Horizonte: FJP,1982.
} 
ao mesmo tempo em que vislumbrava ser através do desenvolvimento regional do estado que se daria o desenvolvimento urbano das cidades mineiras.

Sendo assim, o PROECl buscava ampliar a determinação feita pelo PNCCPM no qual evidenciava-se a ação dos investimentos nos aspectos intraurbanos, ou seja, buscava-se investir em melhorias das características urbanas tais como infra-estrutura básica, transportes, esgotamento sanitário e equipamentos sociais, tais como creche, hospitais.

O PROECI destaca-se e diferencia-se do PNCCPM ao pensar no intraurbano como resultante das ações externas do desenvolvimento local. Ou seja, a atração de uma empresa faria com que houvesse uma melhoria sócio-econômica da população e a locação desta empresa, deveria ser pensada como uma articulação regional, na qual deveriam ser consideradas as tendências de cada micro-região ${ }^{24}$ e de cada meso-região. Ou seja, o pensamento intra-urbano seria resultado de uma articulação e conseqüência do planejamento regional.

Estando Minas Gerais em uma posição mais avançada geograficamente que os estados de São Paulo e do Rio de Janeiro, era evidente a sua maior articulação com o Centro-Oeste e o Nordeste na pretendida "integração nacional" do II PND. Além disto, segundo a FJP (1980a), Minas integralizava as duas estratégias do referido plano: a da integração nacional pela posição geográfica e a da potencialidade de redução da balança de pagamentos, frente ao potencial de recursos presentes em seu solo.

Os interesses nacionais no estado seriam então:

a) Fortalecimento do vértice do triângulo formado por Belo Horizonte, São Paulo e Rio de Janeiro;

\footnotetext{
24 Micro e meso-regiões são divisões territoriais estabelecidas pelo IBGE para fins de planejamento. A FJP adota estas divisões, no documento: Programa Estadual de Centros Intermediários: concepção, metodologia e síntese, para fins de planejamento econômico (FJP, 1986).
} 
b) Fortalecer a rede urbano-industrial das regiões sob influência direta dos pólos nacionais, visando a desconcentração e o melhor ordenamento da indústria nesta região;

c) Permitir a integração das economias das macro-regiões noroeste e centro-oeste à centro-sul, criando condições de desenvolvimento integrado urbano-rural nas regiões norte, nordeste e noroeste do estado, integrando-as efetivamente à área de influência da macro-região de Belo Horizonte;

d) Consolidar o sistema estadual de cidades em função dos objetivos nacionais de desconcentração espacial pela afirmação dos pólos alternativos desenvolvimento no interior. (FJP, 1980a).

Já os objetivos que eram considerados de interesse do estado quanto ao desenvolvimento regional eram:

a) Integrar com a economia de Belo Horizonte;

b) Fortalecer o crescimento das regiões com dinâmica própria e alto potencial de recursos;

c) Atenuar os desequilíbrios de renda;

d) Conformar e consolidar um sistema de cidades de distintos níveis de hierarquia, que ampliassem as possibilidades de desenvolvimento urbano, dando dinâmica também ao espaço rural. (FJP, 1980a).

As diferenças do estado de Minas Gerais eram essencialmente marcadas pela necessidade de se efetuar um programa. Por um, lado, algumas regiões haviam sido beneficiadas com alguns fatores de desenvolvimento e introduzido prejuízo na organização espacial inter-regional pelo transbordamento das capitais nacionais São Paulo e Rio de Janeiro.

A descontinuidade sempre foi um aspecto muito relevante ao planejamento de Minas. Algumas cidades recebem muita potencialidade e acabam abrangendo ou polarizando um amplo território, sem que a metrópole tenha conseguido alcançar tamanho e importância funcionais que lhe permitissem polarizar e integrar todo o território mineiro.

O PROECI buscou desenvolver ações que facilitassem a integração do estado e deste com as outras regiões do país, conforme os objetivos do II PND. Buscou ambém ressaltar a necessidade de elevar o nível hierárquico de vários 
centros para que a estrutura urbana pudesse estar baseada no equilíbrio maior entre lugares centrais. Assim sendo, na concepção do programa aparecia a idéia de que um programa de cidades médias procurava dar ênfase nas relações das diversas cidades com a região por elas comandadas, ao invés de privilegiar apenas os aspectos intra-urbanos da cidade com um universo fechado.

Neste sentido, deveria ser reafirmada a base produtiva de cada localidade vislumbrando fazerem-se investimentos nos locais nos quais houvesse maior potencial de retorno, ou seja, naqueles locais onde os investimentos pudessem mais rapidamente elevarem o nível de bem-estar da população.

Ocorreu a preocupação de assegurar que algumas cidades pudessem cumprir o papel de reorientação e contenção do fluxo migratório, uma vez que o saldo populacional do estado era de perda de população. Deveriam então, serem efetivadas ações em áreas de expulsão, estagnação ou congestionamento ${ }^{25}$.

O caráter mais relevante dado ao projeto era o da necessidade de se ter um aumento substancial de bem-estar e condições de vida para a população.

Neste sentido, as ações propostas pelo PROECI foram específicas para a realidade de cada região encontrada. Primeiramente fez-se necessária a identificação das regiões que deveriam ser alvo do programa, através da análise das 52 micro-regiões de então e daquelas dentre estas que possuíssem o maior números de ocorrências - pobreza, demografia, espacial e potencial de retorno.

25 Cabe o seguinte destaque quanto à questão migratória para o estado de Minas Gerais:

A região Metropolitana de Belo Horizonte, por seu lado, é a que apresenta maior taxa de crescimento populacional. A esse respeito, parece ter sido a única alternativa para os imigrantes que se destinaram a Minas Gerais; possuía 30\% dos migrantes do estado (por sinal, um dos maiores fornecedores de população, embora contendo apenas $13 \%$ da população total). (BRASIL, 1975, p. 54).

Belo Horizonte cresceu a uma taxa geométrica anual de 6,1\%, enquanto São Paulo cresceu a 5,5; Recife e Rio de Janeiro apresentaram as menores taxas de entre as Regiões Metropolitanas, respectivamente 3,7 e 3,9\%, apesar da importância do crescimento bruto (550 mil e 2,2 milhões) dessas duas metrópoles. (BRASIL, 1975, p. 56). 
A etapa seguinte passou para a definição dos projetos que se articulavam com a dinâmica de cada um dos centros estudados. ${ }^{26}$

Os investimentos feitos tanto pelo PNCCPM quanto pelo PROECl serão ressaltados no capítulo referente ao estudo de caso, no qual a qualidade de vida urbana de cada município será foco da análise.

Cabe ressaltar que, segundo Mendonça (1990, p. 94) que o valor do financiamento feito pelo BID ao PROECI foi de US\$60 milhões, que seria o equivalente a $33 \%$ de toda a participação do BID no país em projetos de desenvolvimento de infra-estrutura urbana entre 1961 e 1979.

Para o momento, cabem algumas considerações de cunho bibliográfico sobre a atuação da política urbana no país.

Ainda com relação à eficácia do PNCCPM, Serra (1991) faz a consideração de que ocorre um crescimento significativo das ligações de água e esgoto; contudo, sem contudo poder ser estabelecida qualquer correlação entre essas constatações e os investimentos do programa. Este autor considera que a tentativa de ação do planejamento federal no nível intra-urbano era na verdade uma tentativa de interferência do poder centralizador e autoritário nas cidades.

O autor credita ao planejamento realizada naquele momento a criação de um banco de dados sobre municípios, coisa precária até então. Segundo ele, o primeiro mapa de muitas das localidades fora elaborados pelas equipes de planejamento.

\footnotetext{
${ }^{26}$ A intervenção quanto ao sistema de abastecimento urbano foi uma das preocupações deste momento. Além disto, a acessibilidade do produtor rural aos mercados de venda, também dinamizaria a função de cada núcleo micro-regional. Cada projeto estava em articulação com a área analisada. Para fins desta pesquisa, cabe ressaltar que Montes Claros e Governador Valadares entrevam com a demanda de geração de emprego e melhoria da qualidade de vida da população urbana de baixa renda. Já Uberlândia, o objetivo principal era o de incentivar as atividades agro-industriais e fortalecer as funções de armazenagem e comercialização para uma melhor integração do centro-sul com o centro-oeste. Para 0 caso de Poços de Caldas e Juiz de Fora, buscava-se um crescimento da produção industrial e um aumento da oferta de bens de consumo coletivo para a população de baixa renda. (FJP, 1980).
} 
Bernardes (1986) destaca que o II PND não conseguiu a implantação preconizada pela CNPU e que a atuação do plano foi contida por limitações inerentes ao sistema de governo excessivamente centralizado e autoritário, que procurava muito mais a manutenção da ordem existente, privilegiando setores da economia articulados com as obras propostas, tais como a construção civil, do que a preocupação com os reais objetivos da política urbana. (BERNARDES, 1986, p.108).

Já para Reis (1996), os princípios determinados pela PNDU estavam corretos, mas foram negados na prática, ocorrendo concentração populacional nas áreas zoneadas para a desconcentração; deterioração da qualidade de vida, agravamento da concentração de renda; redução do nível de emprego a patamares existentes no início da década de 1970 e redução dos investimentos em infraestrutura.

Segundo ele, os planos nacionais de desenvolvimento rão estabeleceram de forma clara uma política territorial e uma política populacional, entendendo estas duas por meio de um conjunto estruturado de diretrizes para orientar a distribuição da população no território. (REIS, 1996, p. 45).

E segundo Souza (2004);

A grande dificuldade foi, sem dúvida nenhuma, de cunho político e também metodológico. Político porque, a meu ver, o essencial da política estava subjacente ao seu significado, que era assumir a sociedade e o espaço como uma totalidade (...). O livre mercado deveria também reger a política urbana.

Uma outra espantosa divergência, esta constante do próprio II PND, era o antagonismo entre as diretrizes da política urbana de caráter eminentemente descentralizador e as diretrizes de caráter centralizador (...)

De qualquer maneira, é importante frisar o caráter inovador e coerente da política urbana então definida. Seus autores tiveram a habilidade de encaminhá-la para fazer avançar, na medida do possível, as preocupações com a urbanização de maneira minimamente sistematizada e politizada. Não há como negar que alguns dos seus efeitos foram positivos: inovações no tratamento do sistema urbano, especialmente nas regiões metropolitanas e cidades médias, o programa de transporte urbano, entre outros. (SOUZA, 20004, p. 141). 
Embora o quadro traçado até aqui tenha sido de uma grande desarticulação entre a União e o município, entre a ação e a prática, alguns autores (MONTE-MÓR, 1981; CARDOSO, 1997; BERNARDES, 1986) considerarem que a efetivação das ações só ocorreria em nível pedagógico, onde as ações não se efetivaram, mas deram como fruto a ampliação do planejamento no Brasil, o planejamento transformou-se em algo passível de averiguação, o que o torna real.

Cabe ressaltar que é neste cenário que a discussão sobre reforma urbana tem sua cerne e pode-se portanto afirmar, que a política urbana atual, chefiada pela Lei n. 10.257 - Estatuto da Cidade, tem também ai seu surgimento. 
3 SUSTENTABILIDADE URBANA: CONCEITUAÇÃO E ABRANGÊNCIA 
ste segundo capítulo busca conhecer como ocorre a propagação do

termo 'desenvolvimento sustentável' e quais suas possibilidades de aplicação na análise e no planejamento do ambiente urbano brasileiro.

O percurso compreendido como adequado nesta inquirição perpassa por diversos temas. Dentre estes, são considerados os seguintes:

a) O que seria 'sustentabilidade'? Parece não existir uma definição exata para o que seja 'sustentabilidade', termo ou paradigma de conduta que possui apenas definições imprecisas.

Em verdade, o termo tem sido recorrentemente utilizado para os mais diversos fins, sempre buscando dar autenticidade ao que o acompanha. Atualmente, 'sustentabilidade' é o adjetivo que melhor qualifica desde o manejo de recursos naturais e do meio ambiente até práticas sociais atualmente consideradas adequadas.

A todo momento emergem propostas governamentais que se intitulam 'sustentáveis' ou então, propagandas de empreendimentos 'sustentáveis'.

Este capítulo inicia-se por tentar um ajuste daquilo que seria a 'sustentabilidade': a conceituação do termo; a contextualização do seu conceito e quais os campos de discussão teórica que o teriam absorvido.

b) Na discussão sobre o surgimento do conceito de 'sustentabilidade', percorreu-se processo de ampliação da discussão mundial sobre a questão ambiental, o que encaminhou o trabalho à leitura dos textos conclusivos das principais conferências internacionais sobre meio ambiente promovidas pela ONU e trabalhos que avaliam tais documentos. Na análise do material encontrado, formam identificadas as abordagens da relação entre crescimento, desenvolvimento econômico e preservação ambiental. 
Por fim, verifica-se não existir um sentido único e utilização para o termo e sim a evolução histórica do enfrentamento da questão ambiental, traduzida por este conceito.

\subsection{SUSTENTABILIDADE - EVOLUÇÃO CONCEITUAL}

O florescimento dos movimentos em defesa do meio ambiente data dos anos de 1960. Alguns autores (NOBRE; AMAZONAS, 2002; TRIGUEIRO, 2003) consideram como sendo um importante momento nesta trajetória, a chegada do homem à Lua. Tendo sido visão da Terra televisionada para todo o mundo desencadeou uma comoção e conscientização sobre a vida no planeta.

A ampliação da discussão sobre questões ambientais vai ocorrer contemporaneamente à revolução das ciências sociais críticas, a partir dos anos 1950. Já os anos 1970 serão marcadamente ampliadores desta discussão, com a publicação de 'Os Limites do Crescimento', pelo Grupo de Roma, grupo formado por especialistas em diversas áreas do conhecimento, originados do Instituto de Tecnologia de Massachusetts. O livro corroborou com uma visão bastante alarmista das condições ambientais do planeta. Em termos gerais, evidenciava uma visão malthusiana, ao abordar a questão ambiental fundada na ambivalência existente entre crescimento populacional em ampliação versus recursos naturais existentes, uma população que aumenta frente a recursos dados, que não sofrerão aumento. A fundamentação desta contradição estava em grande parte na iminência da deficiência de abastecimento advinda com a crise do petróleo no início dos anos 1970, momento em que toda a estrutura de consumo se viu fragilizada frente ao escasseamento deste recurso. 
As discussões em torno do relatório do Grupo de Roma deram encaminhamento aos debates ocorridos em Estocolmo, marco na ampliação da abordagem ambiental para proporções mundiais, dando enfoque internacional ao problema. A partir daquele momento, entre os que assinaram a Declaração de Estocolmo, deveria existir uma colaboração multilateral no encaminhamento de soluções para a crise (ONU, 1973).

Um conceito inerente a este relatório é o da dimensão mundial das questões ambientais, no sentido da inter-relação entre os ambientes do planeta frente à sua capacidade de organização.

Outro conceito muito claro é o do subdesenvolvimento como fator de degradação ambiental. A visão de um crescimento demasiadamente acelerado dos países de terceiro mundo, nos quais a população pobre não possui recursos para manter-se e por este motivo, degradava o meio ambiente, pode ser percebido neste parecer. Este enfoque é posteriormente abandonado a partir da ampliação da visão de desenvolvimento para além do contexto estritamente econômico, pela incorporação do conceito de 'desenvolvimento social' que possibilitou a discussão da inserção das populações pobres aos direitos universais, propugnados pela própria ONU.

No tocante à questão do declínio da qualidade do meio ambiente, 'Os Limites do Crescimento' pauta em boa parte as discussões da década de 1970, como também o faz a primeira Conferência sobre Meio Ambiente realizada em Estocolmo em 1972, primeira agenda ambiental da ONU, dentro de seu programa ambiental Programa das Nações Unidas para Desenvolvimento (PNUD).

A ONU passará a ter papel de destaque na condução da discussão ambiental. Segundo Saule (2001), a ONU tem sua origem coincidindo com o término da II Guerra Mundial, no propósito de manter a paz e evitar um novo conflito 
mundial. Sua criação tem como objetivo estabelecer novas relações internacionais entre o estado e os cidadãos, estes passando a serem sujeitos de direito internacional - cidadãos internacionais e não apenas nacionais - com base no direito humanitário, formulado a partir das Declarações de Direitos Humanos Americana (1776) e Francesa (1789). Desde sua elaboração, a entidade busca: "promover e encorajar o respeito aos direitos humanos e às liberdades fundamentais de todos, sem distinção de raça, sexo ou religião" (SAULE, 2001).

Em 1948, a Organização elaborou a Declaração Universal dos Direitos Humanos e, desde então, vem sendo constituídos mecanismos de tutela dos direitos humanos, em todos os países que se alinham com este pensamento, prática política e econômica. Desde os anos de 1960, sua atuação vem se pautando pelo estabelecimento de instrumentos e mecanismos de proteção dos direitos humanos através da criação de convenções e tratados internacionais.

Como estratégia para enfrentamento dos problemas sociais e econômicos, a ONU realiza conferências ligadas aos temas globais, tentando estabelecer programas e planos de ação que direcionem a atuação de seus organismos e agências especializadas nos diversos países que tomam assento nas decisões por ela encaminhadas.

Segundo Nobre e Amazonas (2002), o enfrentamento da questão ambiental se baseia, em um primeiro momento, na literatura alarmista de 'Os Limites', que promulgava a idéia do crescimento zero. Em um momento subseqüente, sobre a influência da ecologia política, desenvolve-se o conceito do ecodesenvolvimento, no qual a forma produtiva desenvolvida pela sociedade como um todo deveria ser transformada em outra mais adequada a uma sociedade em equilíbrio com o meio ambiente. 
Ocorre aí uma modificação na forma de abordagem da questão desenvolvimentista. Anteriormente propugnada a necessidade de crescimento zero pelo livro 'Os Limites', localizava o impasse na relação do desenvolvimento econômico com a preservação do meio natural, contradição demonstrada desde Carl Marx. Já o ecodesenvolvimento sugeria a revolução social com modificações profundas desde o modo de produção até nas formas de exploração do homem pelo outro homem, aproximando-se da abordagem da ecologia política. Preconizava a ampliação da qualidade de vida para todos os indivíduos do ecossistema Terra.

Estas correntes das ciências sociais foram importantíssimas na evolução do conceito do que deveria ser incluído nas análises sobre 'desenvolvimento sustentável'. Foram tais análises críticas que possibilitaram avanços do paradigma atrelado apenas ao crescimento econômico para introduzir fatores sociais ao processo.

Em 1976, em Vancouver, Canadá, ocorreu Conferência das Nações Unidas sobre Assentamentos Humanos (Habitat I), promovida pela Comissão de Assentamentos Humanos Habitat (UN-Habitat). Na Declaração de Vancouver, temse o reconhecimento de que a relação econômica dos países pobres tornou-se injusta pela própria forma de inserção de cada qual na divisão internacional de trabalho e que o indivíduo só se desenvolve a partir do desenvolvimento do local no qual ele está inserido no mundo. Portanto, a partir deste momento, ocorre incorporase à questão do desenvolvimento a preocupação com a qualidade dos assentamentos humanos, interesse particular deste trabalho.

Em decorrência do Habitat I, começam a serem discutidas as condições básicas que devem estar presentes no ambiente urbano promotor do desenvolvimento humano. Entre estas condições estavam citadas a necessidade de qualificar os assentamentos com condições mínimas de habitação, sendo estas a da 
própria moradia, com número de cômodos adequados ao tamanho das famílias, utilização de materiais apropriados na construção das edificações, presença de infraestrutura básica - abastecimento de água tratada, esgotamento sanitário e destinação de água servida e lixo.

Além da infra-estrutura, a questão da estrutura urbana também foi salientada, evidenciando a necessidade dos equipamentos de consumo coletivo escolas, hospitais, áreas de prática de lazer passivo e ativo - para reprodução da força de trabalho, além das atividades comerciais, serviços e serviços públicos administrativos.

Foi também considerada imprescindível para a adequada habitação a geração de emprego e renda. A necessidade do fim da segregação sócio-espacial e das grandes questões sociais advindas de estruturas fundiárias concentradoras foram também abordadas. O Habitat I definiu a moradia como um direito humano básico que deve ser assegurado pelos governos, na garantia da formação de comunidades não segregacionistas, mais equilibradas, com a combinação de diferentes grupos sociais, ocupações e moradias. (ONU, 1976).

A constituição da Comissão Mundial sobre Meio Ambiente e Desenvolvimento (CMMAD) - a chamada Comissão Brundtland - veio dez anos depois de Estocolmo ${ }^{27}$, também por iniciativa do PNUD.

O termo 'sustentabilidade' teve sua primeira aparição no Relatório da Comissão Brundtland - Nosso Futuro Comum, elaborado pela CMMAD. A conceituação foi amplamente difundida e corresponde aquilo que geralmente entende-se como sendo essencial ao termo:

(...) O desenvolvimento sustentável é aquele que atende às necessidades do presente sem comprometer a possibilidade de as 
gerações futuras atenderem a suas próprias necessidades. Ele contém dois conceitos chaves:

- conceito de "necessidades", sobretudo as necessidades essenciais dos pobres do mundo, que devem receber a máxima prioridade;

- a noção das limitações que o estágio da tecnologia e da organização social impõe ao meio ambiente, impedindo-o de atender às necessidades presentes e futuras. (BRUNDTLAND, 1991).

O Relatório da Comissão Brundtland destaca os três componentes fundamentais do novo modelo de 'desenvolvimento sustentável': proteção ambiental, crescimento econômico e equidade social (SANTILLI, 2005). Ao conceito seria inerente o componente social do desenvolvimento.

Em 1992, aconteceu a ECO-92. Dentre as decisões firmadas entre os participantes, foi tirada a resolução da criação da Agenda 21, que seria uma agenda de atitudes para o enfrentamento da questão ambiental no século que se iniciaria. Dentro desta agenda, ocorreu a compreensão de que sempre seria essencial para o bem-estar econômico, social, psicológico, o acesso a uma moradia sadia e tal objetivo deveria ser parte fundamental das ações nacionais e internacionais. (ONU, 1992).

Para a existência de uma cidade sadia, a Agenda 21 estabeleceu que:

1. sejam aperfeiçoados o manejo dos assentamentos humanos

2. seja promovida a existência integrada de infra-estrutura ambiental: água, saneamento, drenagem e manejo de resíduos sólidos;

3. sejam promovidos sistemas sustentáveis de energia e transporte nos assentamentos humanos;

4. seja promovido o planejamento e o manejo dos assentamentos humanos localizados em áreas sujeitas a desastres;

5. sejam promovidas atividades sustentáveis na indústria da construção;

6. seja promovido o desenvolvimento dos recursos humanos e da capacitação institucional e técnica para 0 avanço dos assentamentos humanos. (ONU, 1992). 
Sendo a ECO-92 uma conferência não centrada na questão dos assentamentos humanos, tema para o qual a ONU destinava uma comissão específica e tendo mesmo assim, sido abordado detidamente a questão da moradia, conclui-se que a questão ambiental urbana estava sendo ampliada e conciliada aos demais temas centrais da crise ambiental. A questão da moradia havia sofrido uma ampliação na qual não apenas a qualidade benfeitoria seria considerada, mas de todo o entorno ao qual pertencia.

No texto da Conferência Cúpula do Rio de Janeiro surge uma ênfase ao conceito de 'sustentabilidade':

Desenvolvimento sustentável é o direito ao desenvolvimento que
deve ser exercido de modo a permitir que sejam atendidas
eqüitativamente as necessidades de gerações presentes e futuras,
no qual, para ser alcançada, a proteção ambiental deve constituir
parte integrante do processo e não pode se considerada
isoladamente deste. (ONU, 1992).

A ECO-92 encaminha duas abordagens de análise. Em uma primeira, relaciona a qualidade ambiental da cidade à disponibilidade de recursos não renováveis para seu funcionamento. Na segunda, corroborou com a corrente do ecodesenvolvimentismo ao afirmar que os processos produtivos na cidade deveriam ter incorporado a ideologia ecológica à sua concepção. Para que pudesse ocorrer a sustentabilidade urbana seria necessária a adoção de práticas sustentáveis em relação à captação e ao manejo dos recursos e dos processos produtivos.

Em 1996, ocorreu a Conferência das Nações Unidas sobre os Assentamentos Humanos, o Habitat II. Nesta conferência, os governos se comprometeram a criar formas de intervenção no ambiente urbano, visando dotá-los de condições 'sustentáveis' de permanência e crescimento. 
Para que firmar o compromisso, foi criada a Agenda Habitat, que ressaltou o direito de moradia estabeleceu como meta a melhoraria das habitações, que para tal deveria ser sadia, segura, protegida, acessível e com serviços básicos.

No texto da agenda é ressaltado o compromisso dos governos que assinaram esta agenda da criação de ministérios para encaminhar soluções às questões de moradia ou agências para alocação de recursos para políticas adequadas.

Pelo exposto através da análise dos textos das conferências, o surgimento do paradigma da 'sustentabilidade' parece ser marcado pela tentativa de reconciliação entre conceitos e dimensões irreconciliáveis, presentes na economia clássica, que dispõe sobre a ambivalência entre desenvolvimento econômico e meio ambiente.

Quando no final dos anos 50, eu terminava a redação desta tese de doutoramento, noções como "consciência ecológica", "limites para o crescimento", "civilização alternativa", "técnicas brandas" ou "crise ecológica" que dominam hoje tanto os debates cotidianos como as discussões científicas, eram ainda desconhecidos. É verdade que a crença ingênua no progresso já havia caído em descrédito. $A$ Dialética da Razão, de Horkheimer e Adorno, entre outros, já nos havia ensinado que o progresso técnico tem como implicação a destruição da natureza. Além disso, aqueles que como eu, haviam se debruçado mais de perto sobre Marx e Engels haviam encontrado também em seus escritos dúvidas quanto aos benefícios do sistema industrial. Nesse meio tempo entretanto, a problemática ecológica tomou dimensões que transcendem os comentários puramente universitários $\mathrm{A}$ questão do progresso tornou-se já há muito tempo a questão da sobrevivência da humanidade. (SCHMIDT, 1962).

Tendo o 'progresso técnico como implicação a destruição da natureza', a sustentabilidade só poderia ser atingida com a modificação das formas de produção técnica. E certamente, este seria o verdadeiro paradigma a ser alterado pela questão ambiental.

Assim, para que o conceito de 'desenvolvimento sustentável' pudesse ser assimilado e tornar-se hegemônico, a ecologia política teve que arrefecer suas 
diferenças com o desenvolvimento econômico, propugnando a nova bandeira com a estampa de que haveria sim alguma conciliação entre a preservação ambiental e o desenvolvimento.

Neste intuito, desenvolveu-se brandamente uma nova base para 0 desenvolvimento, transformado em exploração feita de forma razoável sobre o meio ambiente, visando principalmente incorporar a necessidade de inserção dos processos sociais. Para que não fosse criado um obstáculo ao desenvolvimento econômico, a catastrófica realidade mostrada por 'Os Limites' sujeitourse ao desenvolvimento humano, suavizando a visão apocalíptica.

Para Nobre e Amazonas (2002), a enorme publicidade dada ao tema ambiental teve por intuito institucionalizar sua discussão, fazendo com que as agendas nacionais o adotassem. Porém, ocorreu perda significativa de seu valor político, ou seja, nesta institucionalização, o que se deu foi uma combinação de que não há nenhum empecilho na continuidade do crescimento e desenvolvimento econômico desde que estejam devidamente adjetivados como 'sustentáveis'.

Para alguns autores, o termo nada mais é que uma nova roupagem da economia liberal que procura as bases para a sustentação e manutenção do modo de produção existente através da reserva de matéria-prima pelos grupos que dominam os processos produtivos em todo o mundo.

Da Conferência sobre Meio Ambiente realizada em Estocolmo, em 1972, até a Conferência das Nações Unidas sobre os Assentamentos Humanos, em Istambul, em 1996, foi sendo entendida a questão da diferença dos assentamentos humanos produzidos pelos países ricos e os países pobres. Se em Estocolmo declarou-se ser predatória a ação dos mais pobres sobre a natureza, em Istambul criourse uma agenda habitacional para atendê-los. (ONU, 1996). 
O conceito de 'sustentabilidade' caminhou paralelamente às ideologias dominantes em cada tempo. Os pobres do planeta passaram de agentes a vítimas da degradação ambiental. Da mesma forma, o desenvolvimento passou de econômico a 'sustentável'. Roupagem nova para velhos monopólios ou não, o passivo humano começa a fazer parte da abordagem, no momento em que o desenvolvimento passa a contemplar e assimilar as questões sociais mundiais.

'Sustentabilidade' serve para polemizar e ampliar a discussão daquilo que deve fazer parte do desenvolvimento do ambiente. A discussão e a especulação normativa são, na verdade, um dos sentidos da pesquisa acadêmica.

\subsubsection{O Ambiente Urbano}

A distinção clara entre meio natural e meio cultural e ainda meio culturalmente modificado, conduz a uma série de conjecturas iniciais sobre o ambiente da cidade.

A cidade é resultante de interações sociais sobre o meio ambiente natural. Em decorrência das diversidades culturais existirão várias expressões sobre o espaço. A análise do ambiente da cidade compreende necessariamente a fusão do ambiente natural com a modificação advinda das interações sociais ai exercidas.

Sendo assim, cada cidade possui determinantes físico-espaciais e determinantes sócio-espaciais. Físico-espaciais serão pertinentes à singularidade das localidades geográficas, enquanto os sócio-espaciais, às características culturais.

Com a ascensão do modo de produção industrial, ainda nos séculos XVI e XVIII da era contemporânea, a cidade amplia-se na paisagem.

O desenvolvimento desta forma de organização humana, incipiente ainda no início do século vinte, passa a ser predominante até o fim do mesmo período. 
Uma característica que define o espaço urbano é a da concentração de população, numa diferenciação completa da ocupação rural, baixa e espraiada no território. Tal densidade com que ocorre a ocupação do espaço pelo urbano vai fazer com que necessidade da infra-estrutura seja cada vez mais premente. Como a infraestrutura está sempre em defasagem nas ditas cidades liberais (BENÉVOLO, 1981), a ocupação urbana tende a adquirir as características insalubres, pouco adequadas a vida urbana e que na organização humana com características rurais eram diluídas pela baixa concentração existente.

Considera-se que o próprio termo 'urbano' já seria uma contraposição ao termo natureza. Em muitos estudos ambientais, a dimensão espacial/urbana das análises permanece subestimada, até mesmo negada como não-ambiental, nãonatural. (COSTA, 2000, p. 57).

Como a segunda metade do século XX é marcada pela discussão ambiental ao mesmo tempo em que as cidades passam a ter predominância em números relativos e absolutos sobre o campo, seu ambiente começa a ser incorporado às questões ambientais, de análises a ntes restritas ao meio natural.

Para o caso do Brasil, a ampliação do sistema urbano e da população brasileira ras cidades nos últimos sessenta anos, demonstra que se parte de um quadro percentual de $31 \%$ em 1940, para chegar-se $81 \%$, em 2000. Percebe-se então, que a dimensão da questão ambiental no Brasil está provavelmente deslocada do foco das questões de preservação da mata amazônica para a gestão do ambiente urbano. (ANDRÉS, 1998).

O cidadão urbano vive em más condições ambientais e com baixa qualidade de vida, em cidades carentes de infra-estrutura. Premido pela falta de infra-estrutura de água e de esgotos, carência de serviços de transporte e pavimentação viária, pela falta de leitos hospitalares ou de atendimento em postos de saúde e pela falta de vagas em escolas, o cidadão urbano demanda soluções para tais problemas. Políticos e administradores ainda relegam a segundo plano ações de melhoria ambiental, tais como o provimento de áreas 
verdes e de recreação, o controle da poluição do ar, da água, sonora, a disposição final de resíduos sólidos. Enquanto isso, cresce a dívida ambiental nas cidades brasileiras, especialmente nas de maior porte. (ANDRÉS, 1998).

Além disto, o modelo de ocupação adotado no caso das cidades brasileiras possui um elevado grau insustentabilidade ambiental. Trata-se de um modelo que estrutura o crescimento urbano baseado na expansão horizontal e no crescimento como ampliação permanente de fronteiras, na subutilização das infra-estruturas e urbanidade já instalada e no deslocamento do automóvel, produzindo cidades na iminência de um apagão logístico. O padrão de ocupação predominante é baixo, sem presença da infra-estrutura necessária. (BRASIL, 2004).

Como foi visto ao longo deste texto, o debate ambiental ganha proporções mundiais a partir de 1960, período de relativa contemporaneidade da urbanização da pobreza no Brasil. Junto com ela, os problemas ambientais urbanos se elevavam, contribuindo para a configuração da crise urbana.

$\mathrm{Na}$ ausência da qualidade ambiental das cidades brasileiras, reside o foco de muitas das questões ambientais ou, ao menos, da grande extensão do problema ambiental urbano. O termo 'resiliência' utilizado por Acselrad (1999) vem da Ecologia através da análise dos ecossistemas ecológicos, sendo estes últimos sustentáveis uma vez que conseguem sempre um reequilíbrio dos fluxos necessários à vida de forma a não colocá-la em risco (CAPRA, 2003, p. 25).

As cidades brasileiras possuem uma resiliência muito baixa, ou nos termos colocados por Dias (2002), sua pegada ecológica amplia-se para muito além do limite do seu território, alcançando níveis de insustentabilidade que necessitam serem reavaliados. 


\subsection{CONSIDERAÇÕES FINAIS}

A definição do termo 'sustentabilidade' é imprecisa e variada, mas para fins desse como se viu. Para que se possa estabelecer uma relação de 'sustentabilidade' para um ambiente foi criada uma matriz na qual são expostas categorias de indicadores e indicadores que são importantes na configuração de um espaço com níveis e capacidade de suporte para sua população.

Foi então formatada a Matriz de Qualidade do Ambiente Urbano, que pode ser vista no quadro 7 .

\section{Quadro 7 - Matriz de Qualidade de Vida Urbana}

\begin{tabular}{|c|c|c|}
\hline Categoria & & Indicadores \\
\hline \multirow{2}{*}{ 1. Abastecimento domiciliar de água } & \multicolumn{2}{|c|}{ Acesso à água potável } \\
\hline & \multicolumn{2}{|c|}{ Proporções de domicílios com melhoria de acesso ao abastecimento de água } \\
\hline \multirow{7}{*}{ 2. Saneamento básico } & \multicolumn{2}{|c|}{ Coleta de água servida } \\
\hline & \multicolumn{2}{|c|}{ Proporcões de domicílios com melhoria de acesso ao saneamento } \\
\hline & \multicolumn{2}{|c|}{ Proporções de domicílios com melhoria de acesso à instalações sanitárias } \\
\hline & \multicolumn{2}{|c|}{ Águas residuais tratadas } \\
\hline & \multicolumn{2}{|c|}{ Recolhimento regular de dejetos sólidos } \\
\hline & \multicolumn{2}{|c|}{ Adequada disposição do lixo } \\
\hline & \multicolumn{2}{|c|}{$\begin{array}{l}\text { Promoção integrada de infra-estrutura ambiental: água, saneamento, drenagem } \\
\text { e manejo de resíduos sólidos }\end{array}$} \\
\hline \multirow{10}{*}{ 3. Habitação } & \multicolumn{2}{|c|}{ Percentual de população acima do limiar da pobreza } \\
\hline & \multirow[b]{2}{*}{ Densidade } & Área suficiente para viver \\
\hline & & $\begin{array}{l}\text { Proporção de domicílios com menos de três pessoas por } \\
\text { cômodo }\end{array}$ \\
\hline & \multirow{3}{*}{ Benfeitoria } & $\begin{array}{l}\text { Utilização materiais permanentes que propiciem uma habitação } \\
\text { segura e duradoura }\end{array}$ \\
\hline & & Conexões hidro-sanitárias internas ao domicílio \\
\hline & & Construída fora de áreas de risco \\
\hline & \multirow{4}{*}{ Posse } & Habitação cuja ocupação esteja assegurada \\
\hline & & Financiamento de habitações \\
\hline & & Relação preço da terra versus ingresso no mercado de terra \\
\hline & & $\begin{array}{l}\text { Preço da habitação e coeficiente de habitações acrescidas no } \\
\text { montante total }\end{array}$ \\
\hline \multirow[t]{5}{*}{ 4.Desenvolvimento técnico-tecnológico } & \multicolumn{2}{|c|}{ Aperfeiçoados o manejo dos assentamentos humanos } \\
\hline & \multicolumn{2}{|c|}{ Sistemas sustentáveis de energia e transporte nos assentamentos humanos } \\
\hline & \multicolumn{2}{|c|}{ Prevenção de desastres e instrumentos de mitigação } \\
\hline & \multicolumn{2}{|c|}{ Atividades sustentáveis na indústria da construção } \\
\hline & \multicolumn{2}{|c|}{ Capacitação institucional e técnica para o avanço dos assentamentos humanos } \\
\hline \multirow[t]{2}{*}{ 5.Infra-estrutura viária } & \multicolumn{2}{|c|}{ Modos de transporte } \\
\hline & \multicolumn{2}{|c|}{ Sistemas sustentáveis de transporte } \\
\hline \multicolumn{3}{|c|}{ 6.Existência de áreas verdes suficientes ao exercício das atividades de lazer } \\
\hline \multicolumn{3}{|c|}{ 7.Adequação quanto à concentração humana- Densidade população/ área urbanizada } \\
\hline
\end{tabular}


Toda a formatação e metodologia adotada para a criação da matriz, bem como a origem dos dados nela estabelecidos pode ser vista no item 1- Introdução deste trabalho.

A matriz foi criada como uma ferramenta para aferição tanto da pertinência dos ambientes urbanos em relação aos critérios de 'sustentabilidade' necessários para seu desenvolvimento, quanto para que pudessem ser verificadas as ações das políticas públicas sobre o ambiente urbano, objetivo deste trabalho.

No capítulo seguinte, será feita uma abordagem dos municípios escolhidos como estudo de caso para este trabalho e sobre eles será aplicada a Matriz de Qualidade de Ambiente Urbano.

Não se pretende exaurir o tema de 'sustentabilidade urbana' com este trabalho, nem esgotar as possibilidades e características que devam estar presentes em um ambiente urbano 'sustentável' com a criação desta matriz. Procura-se apenas contribuir para a ampliação da discussão sobre o ambiente urbano, tanto na procura de formas de ocupação menos devastadoras, como na busca por parâmetros que impreterivelmente devam se fazer presentes para que a existência de um ambiente urbano saudável e sustentável. 
4 ESTUDO DE CASO: O EFEITO DAS POLÍTICAS PÚBLICAS NOS MUNICÍPIOS 
omo estudo de caso, passa-se à análise das políticas públicas, seus resultados para as cidades e a aplicação da Matriz de Qualidade de

Ambiente Urbano. Procura-se, assim, averiguar qual a dimensão de sustentabilidade encontrada, comprovando esta tese.

São estudo de caso as cidades de Governador Valadares, Juiz de Fora, Montes Claros, Uberlândia e Poços de Caldas.

As políticas públicas apresentadas anteriormente e aqui analisadas são o PNCCPM Q o PROECI.

\subsection{GOVERNADOR VALADARES}

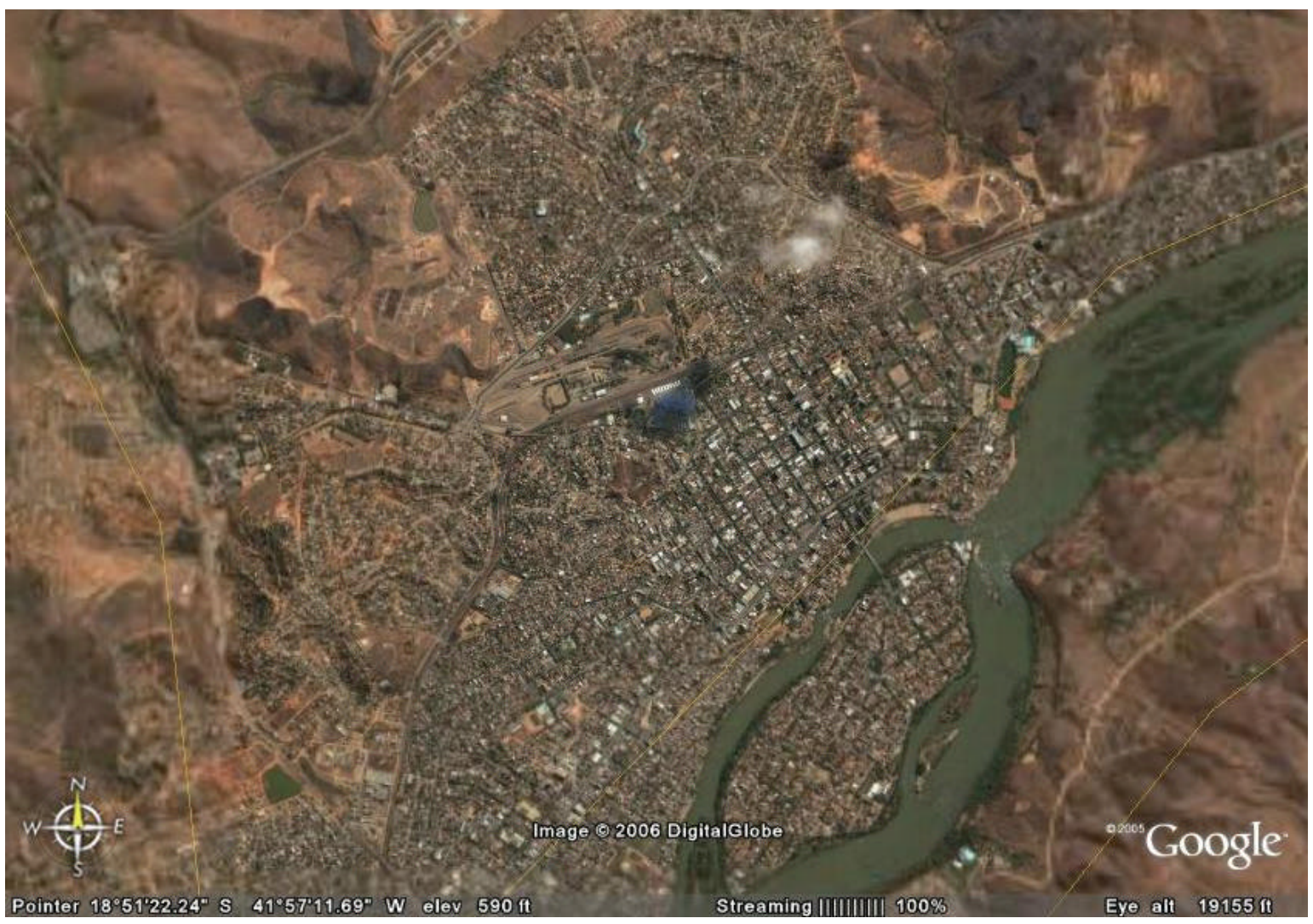

Figura 1 - Vista aérea de Governador Valadares/MG (altitude 5,83 km).

FONTE: Google Earth, Digital Globe. Image @, 2006. 
Governador Valadares ${ }^{28}$ ou Porto de Figueira do Rio Doce até o início do século passado, situa-se em área privilegiada da bacia do Rio Doce. Sua origem ocorreu da necessidade na fixação e domínio do território pela Coroa Portuguesa durante o século XVIII, destacando-se como área estratégica de comércio para a sobrevivência das populações do Nordeste de Minas. Nos primeiros anos do seu desenvolvimento, além da importância do setor terciário, destaca-se a exploração da madeira e a cafeicultura.

Nos anos 40 ocorre um boom da economia regional baseado na exploração de recursos naturais para além da madeira, passando a ter relevância a extração de pedras preciosas e da mica. A cidade passa a ocupar o lugar de centro regional a partir do momento da abertura da rodovia Rio-Bahia (Tabela 1). Do entroncamento da ferrovia Vitória-Minas com a nova rodovia, destacam-se as possibilidades de articulação do município, o que condiciona a um vertiginoso crescimento populacional entre os anos de 1940 - início do funcionamento da articulação viária e 1960.

Governador Valadares é, hoje, pólo regional que exerce influência sobre as microrregiões de Caratinga e Mantena e sobre a zona de Aimorés. Polariza também a região de Mucuri, centrada em Teófilo Otoni, e núcleos urbanos de Vale do Jequitinhonha. Sua influência atinge o Vale do Aço, composto pela conurbação das cidades de Ipatinga, Coronel Fabriciano e Timóteo. A atração exercida por Governador Valadares se estende para os estados vizinhos: norte do Espírito Santo e Sul da Bahia. (ESPÍNDOLA, 1999, p. 13).

\footnotetext{
28 "A PRIMEIRA exploração do Vale do Rio Doce data de 1573 quando Sebastião Fernandes Tourinho, partindo do litoral, subiu o rio até alcançar a foz do Suaçuí Grande, com a finalidade de descobrir ouro e pedras preciosas. Posteriormente, Marcos de Azeredo, seguindo o itinerário de Tourinho, transpôs o rio Doce e avançou uma extensão maior do que a alcançada pela primeira expedição, até atingir a barra do Suaçuí Pequeno. Os desbravadores encontraram uma série de obstáculos, não só o ío, com seus bancos de areia dificultando a interiorização da bacia, como as impenetráveis florestas, e, mais ainda, a ferocidade dos índios botocudos. Esses fatores impediram, por muito tempo, 0 estabelecimento de núcleos regulares de população. Com o intuito de conter os constantes ataques dos silvícolas, instalou-se no Vale, no local conhecido como Porto de Dom Manuel, uma das seis Divisões Militares do Rio Doce, criadas pela Carta Régia de 13 de maio de 1808. Em 1882, o povoado passou a distrito de paz com a denominação de Baguari e, em 1884, a distrito do município de Peçanha, mudando seu topônimo para Santo Antônio de Figueira; em 1923, para Figueira e, em 1938, para Governador Valadares. Instalado o Distrito, foi grande o surto de progresso, especialmente quando da construção da Estrada de Ferro Diamantina, hoje Vitória-Minas. Esse empreendimento muito influiu na colonização do Vale e no rápido progresso de Governador Valadares." (IBGE, 1983).
} 


\section{Quadro 8 - Microrregião de Governador Valadares/MG}

\begin{tabular}{|l|l|}
\hline Macrorregião & Rio Doce \\
\hline Microrregião: & Governador Valadares \\
\hline Municípios: & $\begin{array}{l}\text { Alpercata, Campanário, Capitão Andrade, Coroaci, Divino das Laranjeiras, Engenheiro Caldas, } \\
\\
\end{array}$ \\
& Fernandes Tourinho, Frei Inocêncio, Galiléia, Governador Valadares, Itambacuri, Itanhomi, Jampruca, \\
& Marilac, Matias Lobato, Nacip Raydan, Nova Módica, Pescador, São Geraldo da Piedade, São Geraldo \\
do Baixio, São José da Safira, São José do Divino, Sobrália, Tumiritinga, Virgolândia
\end{tabular}
FONTE: ALMG, 2006.

do Baixio, São José da Safira, São José do Divino, Sobrália, Tumiritinga, Virgolândia

Ainda nos anos 40 , a cidade possuía problemas típicos das zonas pioneiras, como abastecimento de água, saneamento e eletricidade. A malária era um problema tão relevante na região que:

Os problemas da água e das endemias foram resolvidos pelo Serviço Especial de Saúde Pública - SESP, criado em 1942. Este órgão foi resultado dos acordos de Washington, que garantiram para o Vale do Rio Doce e do Rio Amazonas os programas especiais de saneamento, em razão da mica e da seringueira serem matériasprimas estratégicas. (ESPÍNDOLA, 1999, p. 28).

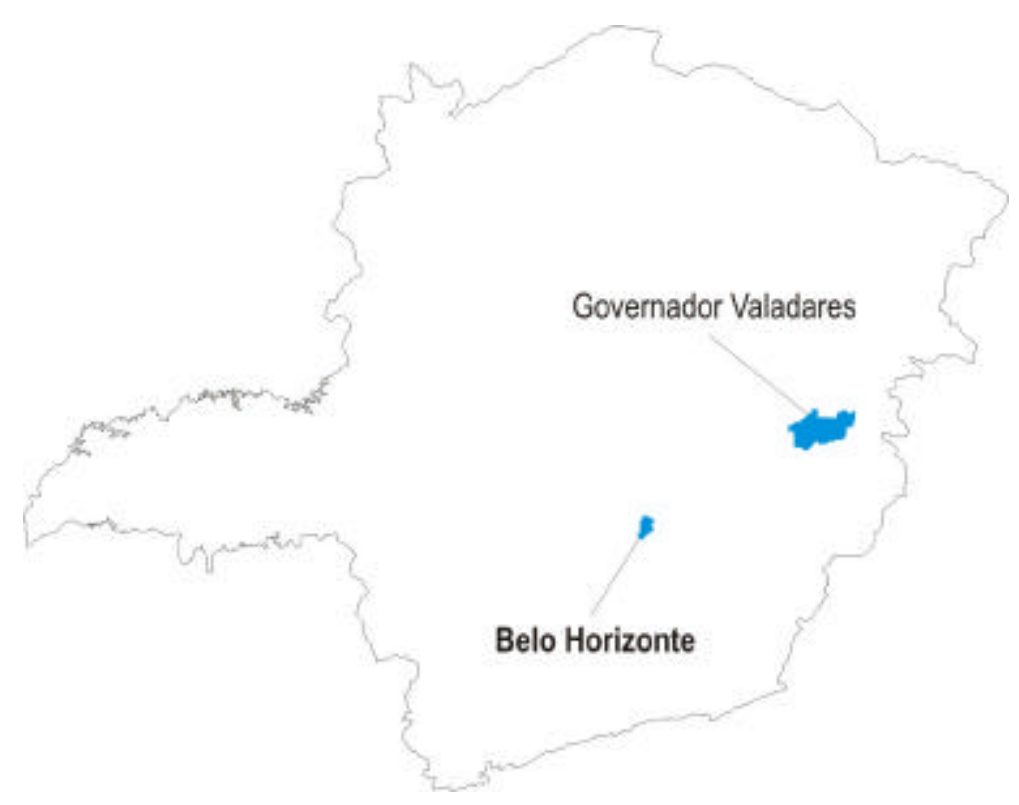

Mapa 7 - Situação de Governador Valadares/MG no Estado, distante 324 km de Belo Horizonte.

FONTE: IGA 1999.

A década de cinqüenta é marcada por um significativo desenvolvimento da cidade, quando a população do município era de 60.958 habitantes, passando para 
120.602 em 1960, para 162.020 habitantes nos anos de 1970, 196.117 habitantes nos anos 1980 e 230.524 habitantes nos anos $1990^{29}$.

Tabela 1 - Evolução da população residente do município de Governador Valadares/MG - 1970, 1980, 1991, 2000, 2005.

\begin{tabular}{l|r|r|r}
\hline \multicolumn{1}{c|}{ Anos } & Urbana & Rural & \multicolumn{1}{c}{ Total } \\
\hline 1950 & & & 60.958 \\
\hline 1960 & 129.378 & 32.642 & 120.602 \\
\hline 1970 & 177.809 & 18.306 & 162.020 \\
\hline 1980 & 215.098 & 15.426 & 196.115 \\
\hline 1991 & 235.881 & 11.016 & 230.524 \\
\hline 2000 & & & 246.897 \\
\hline $2005(1)$ & & & 257.535 \\
\hline
\end{tabular}

(1) Dados preliminares.

FONTE: IBGE.

Segundo Espíndola (1999):

A cidade se beneficiou do crescimento da economia regional, passando a exercer diversas funções: primeiro, tornou-se pólo de beneficiamento e distribuição dos produtos regionais (mica, pedras semipreciosas, madeira, couro, cereais, etc); segundo, passou a ser um importante centro de pecuária, com um dos maiores rebanhos do estado; terceiro, como centro comercial importante, distribuindo produtos nacionais e importados.

A cidade foi também beneficiada pela sua localização no cruzamento de duas importantes vias de comunicação do Sudeste, a ferrovia Vitória-Minas e a Rodovia Rio-Bahia. (...)

O dinamismo econômico de Governador Valadares se fazia notar pela diversificação da oferta de produtos e pelos valores médios dos salários e dos preços, que não se afastavam muitos dos que eram praticados nas cidades do Rio de Janeiro, São Paulo ou Belo Horizonte. Havia uma intensa movimentação de negociantes e representantes das principais firmas comerciais do País. (ESPÍNDOLA, 1999, p. 25).

Com o declínio do extrativismo dos produtos minerais, principalmente a mica, a cidade começa a apresentar sintomas de estagnação.

Desde os anos de 1970, a cidade revela a fragilidade de uma rede centrada em neste centro regional que vem perdendo gradativamente sua capacidade de

29 De 1950 a 1960, Governador Valadares sofreu um acréscimo populacional de cerca de 50 mil habitantes. Sua população, inicial de 60.958habitantes foi para 120.602 habitantes, o que significa que cresceu 1,9 vezes. Já de 1960 para 1970, a variação de aumento de população foi de 1,3 vezes. Dos anos 1970 aos anos 1980, a população aumentou 1,2 vezes. Dos anos de 1980 aos anos de 1990, o aumento foi de 1,17 vezes. (Dados retirados dos Censos do IBGE de cada década). 
geração de riquezas, pela predominância da atividade de pecuária extensiva executada em solos em esgotamento. Segundo Espíndola (1999), a região que era considerada "terra da promissão" passou as ser mencionada como "região problema".

A partir dos anos 50, por iniciativa dos Rotary Club do Brasil, intensificou-se o número de moradores de Governador Valadares que deixavam o Brasil com direção ao Estados Unidos. Esta tendência teve características interessantes ao longo das décadas seguintes, com um aumento cada vez maior de emigrantes desta procedência. O fato gerou importantes impactos na economia valadarense, pois os emigrantes enviavam dinheiro para seus familiares, principalmente na década de 80 , fomentando a indústria da construção civil no município.

A expansão urbana da cidade ocorreu em meio a um intenso processo de especulação imobiliária, que permitiu uma extensão demasiada da zona urbana, com ocupação de áreas alagáveis do rio Doce, em um processo de descontinuidade de ocupação do território do município, que acabou gerando vazios urbanos e baixando as densidades do município, dificultando o atendimento da infra-estrutura básica, para toda a amplitude da urbanização gerada.

O PNCCPM evidenciou esta tendência de formação de vazios, o que encaminhou a necessidade de elaboração de uma legislação normativa da ocupação do espaço urbano, inclusive com a previsão de investimentos tributários que recaíssem sobre as áreas ociosas, além da exposição de um plano de hierarquização viário, renovação da área central e realização de obras de melhoria da infra-estrutura. (FAUUSP, 1984). ${ }^{30}$ 
No programa PNCCPM, Governador Valadares foi contemplada com três convênios. No primeiro deles, foi contratado um total de $\operatorname{Cr} \$ 57,1$ milhões, sendo $\operatorname{Cr} \$ 27,6$ milhões do Estado, $\operatorname{Cr} \$ 18,2$ milhões da União e $\operatorname{Cr} \$ 14,8$ milhões do Município. Do total advindo da União, $\operatorname{Cr} \$ 12,2$ milhões vinham da junção Fundo Nacional de Desenvolvimento Urbano (FNDU) e Fundo Nacional de Transporte Urbano (FNTU), tendo sido aplicado na infra-estrutura viária e transportes, sendo os demais Cr\$ 3 milhões aplicados em planejamento e administração

Tabela 2 - Investimentos urbanos em Governador Valadares/MG. Recursos em Cr\$1.000,00 - 1980.

\begin{tabular}{|c|c|c|c|c|c|c|c|}
\hline \multirow{2}{*}{\multicolumn{2}{|c|}{ Projetos }} & \multirow[b]{2}{*}{ Órgão executor } & \multirow[b]{2}{*}{ Município } & \multirow[b]{2}{*}{ Estado } & \multicolumn{2}{|c|}{ União } & \multirow[b]{2}{*}{ Total } \\
\hline & & & & & $\begin{array}{l}\text { FNDUI } \\
\text { FNTU }\end{array}$ & Outros & \\
\hline \multirow[t]{3}{*}{$1-$} & Planejamento e Administração & & 500 & 701,9 & $3.664,4$ & - & $4.886,3$ \\
\hline & $\begin{array}{l}\text { 1. Revisão e Adequação PDLI, } \\
\text { inclusive Reforma Administrativa da } \\
\text { Prefeitura. }\end{array}$ & $\begin{array}{l}\text { Prefeitura } \\
\text { Municipal }\end{array}$ & 500 & 145 & $2.500(1)$ & - & 3.145 \\
\hline & $\begin{array}{l}\text { 2. Reforço da Capacidade de } \\
\text { Planejamento da Prefeitura }\end{array}$ & $\begin{array}{l}\text { Prefeitura } \\
\text { Municipal }\end{array}$ & & 556,9 & $1.164,4$ & - & $1.721,3$ \\
\hline \multirow[t]{2}{*}{ II - } & Saneamento & & $14.348,8$ & $25.019,9$ & $14.556,9$ & - & $53.925,2$ \\
\hline & $\begin{array}{l}\text { 1. Urbanização dos Bairros Vila São } \\
\text { Raimundo, Jardim Vera Cruz e Vila } \\
\text { Iza, inclui Pavimentação Drenagem } \\
\text { e Rede de Esgotos. }\end{array}$ & $\begin{array}{l}\text { Prefeitura } \\
\text { Municipal }\end{array}$ & $14.348,8$ & $25.019,9$ & $14.556,9$ & - & $53.925,2$ \\
\hline \multicolumn{2}{|c|}{ TOTAL } & & $14.848,8$ & $25.721,8$ & $18.221,3$ & - & $58.8111,5$ \\
\hline
\end{tabular}

(1) Saldo Convênio FNDU no 32/78 - E.M. nº 206/78.

FONTE: Convênio 32/78 do Programa de Investimentos Urbanos e Programa de Apoio às Capitais e Cidades de Porte Médio, Estado de Minas Gerais.

Também o município centrou na infra-estrutura viária e de transportes a maior parte dos recursos investidos. O total de investimento na área infra-estrutura viária e transportes foi de $\operatorname{Cr} \$ 28,55$ milhões de um montante de aproximadamente quarenta milhões.

O segundo convênio aloca recursos na administração, planejamento e saneamento, sendo este último o receptor da maior parte dos $\operatorname{Cr} \$ 18,2$ milhões disponibilizados pela União, estado e município.

O terceiro convênio teve a aplicação de cerca de $\operatorname{Cr} \$ 182$ milhões, sendo que grande parte foi em crédito à micro-empresa, além de infra-estrutura social, da 
qual resultou a construção de dois centros de saúde e um centro de bairro, além de projetos para canalização de córregos.

Tabela 3 -

Investimentos urbanos em Governador Valadares/MG. Recursos em Cr\$ 1.000,00 - 1978/1979 (10 semestre).

\begin{tabular}{|c|c|c|c|c|c|c|c|}
\hline \multirow[b]{2}{*}{ Projetos } & \multirow[b]{2}{*}{ Órgão executor } & \multirow[b]{2}{*}{ Município } & \multirow[b]{2}{*}{ Estado } & \multicolumn{3}{|c|}{ União } & \multirow[b]{2}{*}{ Total } \\
\hline & & & & $\begin{array}{l}\text { FNDUI } \\
\text { FDTU }\end{array}$ & $\begin{array}{l}\text { FNDU } \\
\text { OP }\end{array}$ & Outros & \\
\hline I - Planejamento e Administração & & 500 & - & 1.500 & - & 2.000 & \\
\hline $\begin{array}{l}\text { Revisão e adequação do PDLI, inclusive } \\
\text { Reforma Administrativa da Prefeitura }\end{array}$ & Prefeitura Municipal & 500 & - & - & 1.500 & - & 2.000 \\
\hline II - Infra-Estrutura Viária e Transportes & & 7.000 & $9.300,3$ & 12.250 & - & - & 28.550, \\
\hline 1-Implantação e recapeamento de vias & Prefeitura Municipal & 7.000 & $\begin{array}{r}3.000 \\
\text { IULCLG }\end{array}$ & 12.250 & - & - & 22.250 \\
\hline 2-Construção de Viaduto Rua Israel Pinheiro & Prefeitura Municipal & - & $3.420,3$ & - & - & - & 3.420 \\
\hline 3-Alargamento da Ponte Ilha dos Araújos & Prefeitura Municipal & - & 2.880 & - & - & - & 2.880 \\
\hline III - Saneamento & & 1.500 & $6.193,7$ & - & 1.500 & 一 & 9.193 \\
\hline $\begin{array}{l}\text { Implantação da rede de drenagem pluvial } \\
\text { (Ilha dos Araújos, Companhia Vale do Rio } \\
\text { Doce, bairros de Lourdes, Esplanada e } \\
\text { Avenida Minas Gerais) }\end{array}$ & Prefeitura Municipal & 1.500 & $\begin{array}{r}4.833,7 \\
\text { IULCLG }\end{array}$ & - & 1.500 & - & 7.833, \\
\hline Interceptor de esgoto do Ribeiro Figueirinha & Prefeitura Municipal & - & $\begin{array}{r}1.360 \\
\text { IULCLG } \\
\end{array}$ & - & - & - & 1.360 \\
\hline TOTAL & & 9.000 & $15.494,0$ & 12.250 & 3.000 & - & 39.743 \\
\hline
\end{tabular}

FONTE: Programa de Investimentos Urbanos para Capitais e Cidades de Porte Médio, Estado de Minas Gerais.

Tabela 4 -

Investimentos urbanos em Governador Valadares/MG. Recursos em Cr\$1.000,00 - 1982.

\begin{tabular}{|c|c|c|c|c|c|c|}
\hline \multicolumn{2}{|r|}{ Projetos } & \multirow[t]{2}{*}{$\begin{array}{l}\text { Unidade } \\
\text { Executora }\end{array}$} & \multirow{2}{*}{$\begin{array}{r}\text { Município } \\
3.864 \\
\end{array}$} & \multirow{2}{*}{$\frac{\text { Estado }}{-}$} & \multirow{2}{*}{\begin{tabular}{r|} 
União \\
15.454 \\
\end{tabular}} & \multirow{2}{*}{$\begin{array}{l}\text { Total } \\
19.318 \\
\end{array}$} \\
\hline I- & Planejamento e Administração & & & & & \\
\hline & 1. Reforço Institucional às Prefeituras & Prefeitura e FJP & 3.864 & 一 & 15.454 & 19.318 \\
\hline II - & Infra-estrutura Social & & - & 58.587 & - & 58.587 \\
\hline & 1. Construção de dois centros de Saúde & SES/MG & - & 12.683 & - & 12.683 \\
\hline & 2. Construção de um Centro de Bairro & Prefeitura & - & 45.904 & - & 45.904 \\
\hline III - & Urbanização & & - & 11.919 & - & 11.919 \\
\hline & $\begin{array}{l}\text { 1. Elaboração do Projeto Executivo de } \\
\text { Urbanização de Córrego Figueirinhas }\end{array}$ & FJP & - & 11.919 & - & 11.919 \\
\hline IV - & Infra-estrutura Econômica & & - & 92.008 & - & 92.008 \\
\hline & $\begin{array}{l}\text { 1. Construção de duas micro-unidades de } \\
\text { Produção }\end{array}$ & SETAS/MG & - & 13.804 & - & 13.804 \\
\hline & 2. Construção de uma feira coberta & $\begin{array}{ll}\text { SEAPA/MG } & \mathrm{e} \\
\text { CEASA/MG } & \end{array}$ & - & 15.644 & - & 15.644 \\
\hline & 3. Crédito às micro-empresas & BDMG & - & 62.560 & - & 62.560 \\
\hline \multicolumn{3}{|c|}{ TOTAL } & 3.684 & 162.514 & 15.454 & 181.832 \\
\hline
\end{tabular}

FONTE: Programa Estadual de Centros Intermediários, Minas Gerais.

Quanto aos investimentos do PROECI, segundo o diagnóstico apresentado pela FJP, a cidade de Governador Valadares necessitava de investimentos no setor 
secundário, pela constatação de que o setor terciário estava saturado em relação à polarização que exercia em sua região.

Segundo o programa, os investimentos no terciário seriam incapazes de absorver os elevados fluxos migratórios que possuía o município. Os investimentos deveriam ser feitos na produção de bens de consumo duráveis, tais como móveis, sapatos, confecções. (FJP, 1980b, p. 134).

Ainda segundo este diagnóstico, os serviços de abastecimento de água e esgotamento sanitário, feitos pelo Serviço Autônomo de Água e Esgoto (SAAE), abasteciam respectivamente $80 \%$ e $50 \%$ do total da população do município de Governador Valadares, dados bastante semelhantes aos apresentados pelo IBGE para o período, de respectivamente $75 \%$ e $55 \%$.

Sendo um município situado nos terraços inundáveis do rio Doce é bastante relevante outro dado apresentado no referido relatório, no qual da drenagem urbana no município, executada pelo Serviço Municipal de Obras e Viação (SEMOV), era contemplada para apenas $10 \%$ do total de vias existentes no município.

Já a coleta de lixo doméstico atingia $50 \%$ da população, sendo feita em determinados trechos com presença de pavimentação inadequada ao tráfego dos veículos destinado a este fim. Soma-se a este, outro, o da população que possuía luz, sendo $55 \%$ do total da população do município, sendo que a esta somava-se mais $10 \%$ que possuía apenas rede na via pública. (FJP, 1980b).

Segundo as características de baixa densidade, para o momento do estudo acima citado, estimava-se haver aproximadamente 24.000 lotes vagos no município. Considerando para fins de análise, o tamanho médio da família naquele período como sendo de 4,6 habitantes $^{31}$, obteremos uma população de 110.400 pessoas que potencialmente poderiam estar ocupando estes lotes. Sendo a população da cidade 
no período equivalente a 179.000 habitantes, o número calculado corresponde a um aumento de mais de $60 \%$ da população existente na cidade. A municipalidade estaria pagando 1,6 vezes o custo necessário para a manutenção da infra-estrutura urbana. Ou seja, a capacidade ociosa de infra-estrutura que estaria custando aos cofres públicos para sua manutenção e implantação, seria suficiente para aquele tamanho de população, resolvendo por completo a oferta de lotes para a população naquele momento ${ }^{32}$.

Segundo os dados difundidos pelo Plano Diretor Municipal (PREFEITURA..., 1991), o quadro da distribuição de terra no município seria alterado nos anos seguinte, mas sempre demonstrando elevada concentração e vazios urbanos.

\section{Quadro 9 - Áreas disponíveis no perímetro urbano}

\begin{tabular}{|l|r|}
\hline \multicolumn{1}{|c|}{ Áreas disponíveis } & ha \\
\hline 1. Área total do perímetro urbano & 17.500 \\
2. Área do Pico do lbituruna & 6.600 \\
3. Área do Rio Doce na cidade & 1.647 \\
4. Total da área parcelável [1-(2+3)] & 9.253 \\
5. Área efetivamente parcelada & 2.672 \\
6. Área dos lotes ocupados & 1.442 \\
7. Área dos lotes vagos & 1.229 \\
8. Área não parcelada & 6.580 \\
\hline
\end{tabular}

FONTE: Cadastro Técnico (PREFEITURA..., 1991).

A Prefeitura Municipal de Governador Valadares apresenta em seu Plano Diretor uma análise que contempla alguns dados relativos à ocupação do solo. A área efetivamente parcelada corresponde a apenas 29\% das áreas disponíveis, enquanto que os $71 \%$ restantes representam diversas glebas não loteadas dentro do perímetro urbano. $\mathrm{O}$ aproveitamento real da área já parcelada é de apenas $53 \%$, os restantes $47 \%$ correspondem, aproximadamente, a 16.633 lotes vagos cadastrados na Prefeitura. Com a média familiar local de 5,14 habitantes por domicilio pode-se calcular que os lotes vagos existentes hoje na cidade podem ser suficientes para

\footnotetext{
32 De acordo com o documento, a Prefeitura representava em números de 13.000 a demanda efetiva correspondente ao número de inscrições para atendimento pela futura Companhia de Habitação do Estado de Minas Gerais (COHAB/MG). (FJP, 1980, p. 140).
} 
atender à população pelo prazo máximo estimado de 26 anos. (PREFEITURA..., 1991).

Tabela 5 - Estimativa de disponibilidade de lotes vagos para atendimento à população de Governador Valadares/MG.

\begin{tabular}{c|c|c|c}
\hline Número de lotes vagos & Incremento Populacional & Média Familiar & Necessidade de lotes/ano \\
\hline 16.633 & 2.733 habitantes/ano & 5.14 habitantes/domicílio & 532 \\
\hline
\end{tabular}

FONTE: PMMGV.

Além dos lotes vagos disponíveis, existem na cidade aproximadamente 6.580 ha de áreas dentro do perímetro urbano que, dependendo de sua localização e condições de infra-estrutura, podem ser parceladas. Se estas áreas fossem divididas em lotes padrões de $360 \mathrm{~m}^{2}$, descontados os $35 \%$ definidos pela Lei Federal de Parcelamento do Solo, em sua versão original de 1970, seriam 118.850 lotes resultantes, o que seria suficiente para atender à demanda de lotes urbanos por um prazo aproximado de 223 anos.

A carência no sistema de esgotamento sanitário se constitui num dos maiores problemas para cidade. A rede que atende apenas $69,89 \%$ dos imóveis cadastrados na Prefeitura, encontrando-se obsoleta e saturada.

Para tanto, a situação de hegemonia na microrregião de Governador Valadares, pressiona a utilização da infra-estrutura existente.

A Matriz de Indicadores apresentada no Quadro 10 permite que seja vislumbrado o aumento da qualidade de vida. Os dados buscam aferir a melhoria da qualidade de vida urbana advinda das ações de tais políticas públicas, embora não sejam elas as únicas explicações. 
Quadro 10 - Matriz de Indicadores de Qualidade de Vida Urbana - Governador Valadares - Matriz com o total dos indicadores

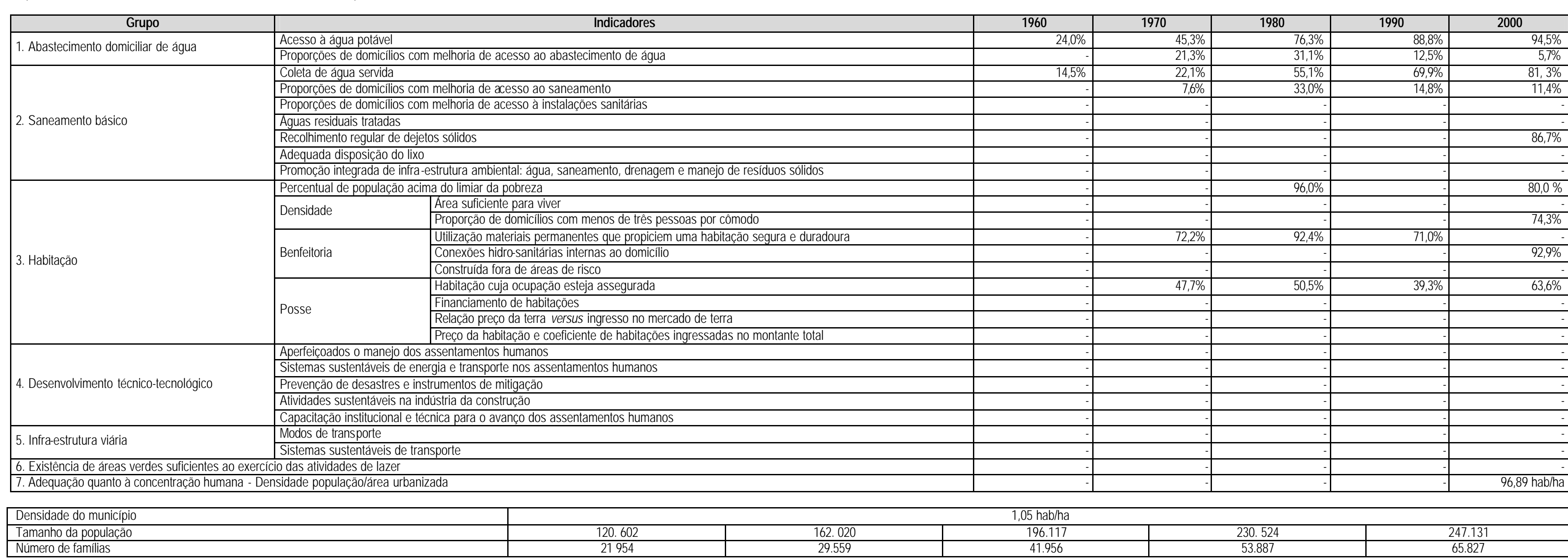

Quadro 11 - Matriz de Indicadores de Qualidade de Vida Urbana - Governador Valadares - 1aㅡ ordenação dos dados

\begin{tabular}{|c|c|c|c|c|c|c|}
\hline Grupo & Indicadores & 1960 & 1970 & 1980 & 1990 & 2000 \\
\hline \multirow{2}{*}{ 1. Abastecimento domicliliar de água } & \multirow{2}{*}{\begin{tabular}{|l} 
Acesso à água potável \\
Proporções de domicilios com melhoria de acesso ao abastecimento de água
\end{tabular}} & $24 \%$ & $45,3 \%$ & $76,3 \%$ & $88,8 \%$ & $94,5 \%$ \\
\hline & & & $21,3 \%$ & $31,1 \%$ & $12,5 \%$ & $5,7 \%$ \\
\hline \multirow{3}{*}{ 2. Saneamento básico } & \begin{tabular}{|l} 
Coleta de água servida \\
Pronorcões de domicilios com melhoria de acesso ao saneamento
\end{tabular} & $14,5 \%$ & $22,1 \%$ & $55,1 \%$ & $69,89 \%$ & $81,3 \%$ \\
\hline & \multirow{2}{*}{\begin{tabular}{|l|} 
Proporçeões de domicilios com melhoria de acesso ao saneamento \\
Recolhimento regular de dejetos sólidos
\end{tabular}} & & $7,6 \%$ & $33,0 \%$ & $\frac{0,050 \%}{14,8 \%}$ & $\frac{01,40}{11,4 \%}$ \\
\hline & & & & & & $86,7 \%$ \\
\hline \multirow{5}{*}{ 3. Habitação } & \begin{tabular}{|l|} 
Recollimimento regular de dejejtos sólilos \\
Percentual de populacão acima do limiar da pobreza \\
\end{tabular} & & & $96,0 \%$ & & $80,0 \%$ \\
\hline & \begin{tabular}{|l|l} 
& Proporção de domiclilios com menos de três pessoas por cômodo \\
\end{tabular} & & & & & $74,3 \%$ \\
\hline & Utilização materiais permanentes que propiciem uma habitação segura e duradoura & & $72,2 \%$ & $92,4 \%$ & $71,0 \%$ & \\
\hline & Conexões hidro-sanitárias internas ao domicílio & & & & & $92,9 \%$ \\
\hline & Habitação cuja ocupação esteja assegurada & & $47,7 \%$ & $50,5 \%$ & $39,3 \%$ & $63,6 \%$ \\
\hline \multicolumn{2}{|c|}{ 7. Densidade populaçãol área urbanizada } & & & & & 96 hab/ha \\
\hline
\end{tabular}

\section{Quadro 12 - Matriz de Indicadores de Qualidade de Vida Urbana - Governador Valadares - composição tonal}

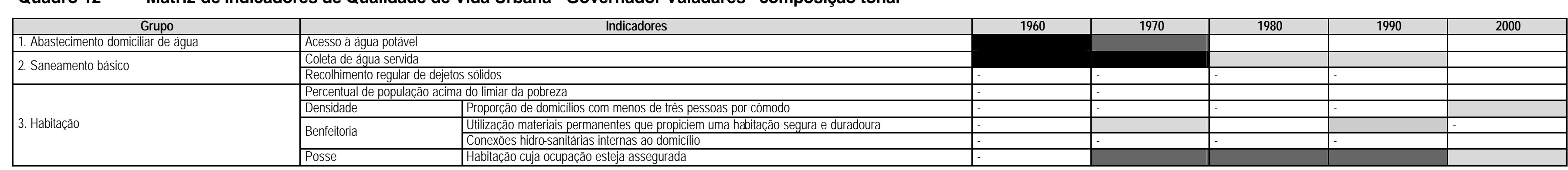


Constata-se que, considerando os indicadores de informação existentes e presentes, a situação ambiental do município, no caso, Governador Valadares, tendeu a uma ascensão de qualidade, haja visto a análise da última coluna da matriz, que para o ano de 2000, que apresenta uma apreciação de valoração prioritariamente superior a $50 \%$.

Na categoria 1 - 'Abastecimento domiciliar de água', pode-se dizer que a melhoria efetiva ocorre exatamente no período de incidência das políticas públicas e seus investimentos. Dos anos 1970 para os anos 1990, o aumento de famílias abastecidas por água da rede geral de abastecimentos é de $43,53 \%$, enquanto o crescimento do número de famílias do município é de $82 \%$. Em 1990, chega-se a um atendimento de quase $90 \%$ da população. A coleta de água servida, apresentada pela categoria 2 - 'Saneamento básico', também tem significativa melhora no mesmo período, passando a abranger cerca de $70 \%$ das famílias na década de 1990, tendo começado com um horizonte de $22,1 \%$ das famílias nos anos de 1970 . No período compreendido entre os anos 1970 e 1990, foi quando da maior proporção de domicílios com melhoria de acesso ao saneamento para este caso, sendo de cerca de $52 \%$.

Os dados para o ano de 2000 revelam uma adequada qualidade ambiental para os parâmetros adotados por este trabalho, pois ambos, abastecimento de água e coleta de esgoto apresentam valores relativos superiores a $75 \%$, conforme estabelecido na metodologia deste trabalho.

Devidamente considerado deve ser o fato da inexistência de uma série histórica de informações para o dado de recolhimento regular de dejetos sólidos. Este dado só está presente para 2000, apresentando $86,65 \%$ das famílias.

Para a categoria 3 - 'Habitação', alguns dados estão presentes, sendo aqui elucidados. O percentual de população acima do limiar da pobreza está presente 
para os anos de 1980 e 2000, havendo uma diminuição relativa nesses 20 anos. Em 1980, eram $96,03 \%$ da população para $80 \%$ em 2000 . Estes números possivelmente apontam para o caráter do empobrecimento geral da população do município e do país.

O número de habitações cuja benfeitoria foi feita utilizando 'materiais permanentes que propiciem uma habitação segura e duradoura' apontam para a atuação das políticas urbana, neste caso provavelmente provenientes da existência do $\mathrm{BNH}$, que tem suas atividades encerradas nos anos 1980, período com maior número de famílias com acesso ao tipo de benfeitoria colocado, ou seja, $92,44 \%$. Os períodos imediatamente anteriores e imediatamente posteriores aos anos 80 têm um patamar semelhante de atendimento deste indicador, que seria em torno de $70 \%$ do total de famílias.

A posse talvez reflita alguma articulação também com a existência da atuação do BNH. No período de 1970 a 1990, localiza-se nos anos 1980 o melhor desempenho do indicador 'Habitação cuja posse esteja assegurada', antes do período de 2000. Em 1980 o valor era de 50,47\% e em 2000, 63,63\%.

No indicador da categoria 7 - 'Adequação quanto à concentração humana densidade população área urbanizada' tem-se 96,89 hab/ha, uma densidade considerada adequada para ocupação humana de clima tropical. Considerando-se a área total do município $2348,1 \mathrm{~km}^{2}$ e sua população de 247.131 habitantes, tem-se uma densidade de 1,052 hab/ha para o município como um todo. Em relação ao estabelecido por Dias (2002), a área disponível por habitante no planeta é hoje um hectare para cada habitante. O município encontra-se dentro da estabelecido.

A Matriz de Qualidade de Ambiente Urbano - Composição Tonal (Quadro 12) permite que seja percebida a totalidade das informações, apenas qualitativamente. Percebe-se do lado direito do quadro a melhora da qualidade ambiental, sendo que 
toda a última coluna, referente ao ano de 2000 , apresenta dados mais adequados à constituição de um ambiente urbano sustentável, conforme parâmetros necessários consolidados pela matriz. A leitura que pode ser feita é a de que a situação ambiental tende a uma melhora.

Considerando que foi possível obter apenas 21 dados dos 140 que foram propostos para a matriz total ${ }^{33}$, tem-se uma estatística que não chega a ser determinante da sustentabilidade do ambiente da cidade, pois 21 dados dotidos correspondem a $15 \%$ do total considerado necessário para análise do município.

Para o caso de Governador Valadares, 15 dos dados estão classificados como estando entre as classes 'média' e 'adequada qualidade' do ambiente urbano, o que equivale a $10,7 \%$ do total, e dentre estes 15,10 dos elementos levantados estão classificados como 'adequada' qualidade do ambiente urbano.

Considerando o universo total como sendo o dos 21 dados obtidos, a sustentabilidade pode ser mais facilmente aceita. Sendo 15 o número de dados entre as classes 'média' e 'adequada qualidade' do ambiente urbano, tem-se 71,4\% e quanto aos 10 dos elementos classificados como 'adequada qualidade' do ambiente urbano, tem-se $47,6 \%$ dos dados.

Tendo como referencial apenas os dados obtidos, o ambiente poderia ser considerado com tendendo à adequação. Como no entanto, o universo de dados sem resposta é muito grande - o que significa uma provável negligência em relação ao seu comportamento - a qualidade estaria comprometida.

Contemporaneamente a este trabalho, está ocorrendo a aprovação dos novos planos diretores e de suas adequações à lei Estatuto da Cidade, o que possivelmente fará com que tais dados sejam postos em foco, uma vez que são 
relativos a diagnósticos de planejamento urbano. Talvez, em um momento subseqüente, estejam disponíveis para uma reformulação da Matriz, que não será certamente abordado neste trabalho.

Considerando também algumas informações sobre indicadores apresentadas pelo IDH-Municipal (PNUD; IPEA; FJP, 2003):

No período 1991-2000, o índice de Desenvolvimento Municipal (IDHM) de Governador Valadares cresceu 7,67\% passando de 0,7171 em 1991 para 0,772 em 2000.

A dimensão que mais contribuiu para este crescimento foi a Educação, seguida pela renda e pela longevidade (...).

Se mantivesse esta taxa de crescimento do IDH, o município levaria 20,4 anos para alcançar São Caetano do Sul (SP), o município como o melhor IDH do Brasil $(0,919)$ e 10,0 anos para alcançar Poços de Caldas (MG), o município com o melhor IDH do Estado $(0,841)$.

Segundo a classificação do PNUD, o município está entre as regiões consideradas de médio desenvolvimento humano (IDH entre 0,5 e 0,8) (PNUD; IPEA; FJP, 2003)
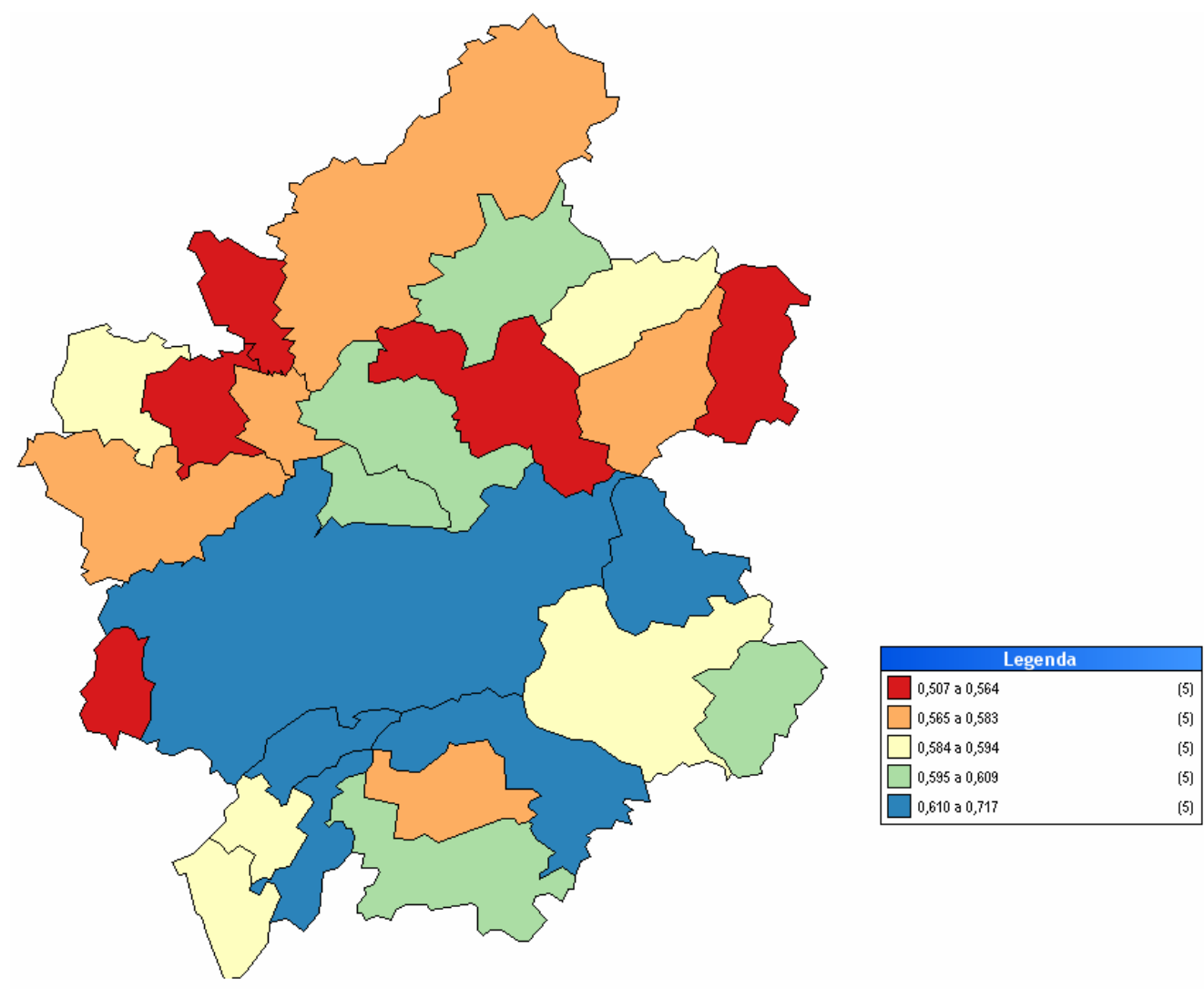

Mapa 8 -

Índice de desenvolvimento humano dos municípios da microrregião de Governador Valadares/MG, 1991.

FONTE: PNUD; IPEA; FJP, 2003. 


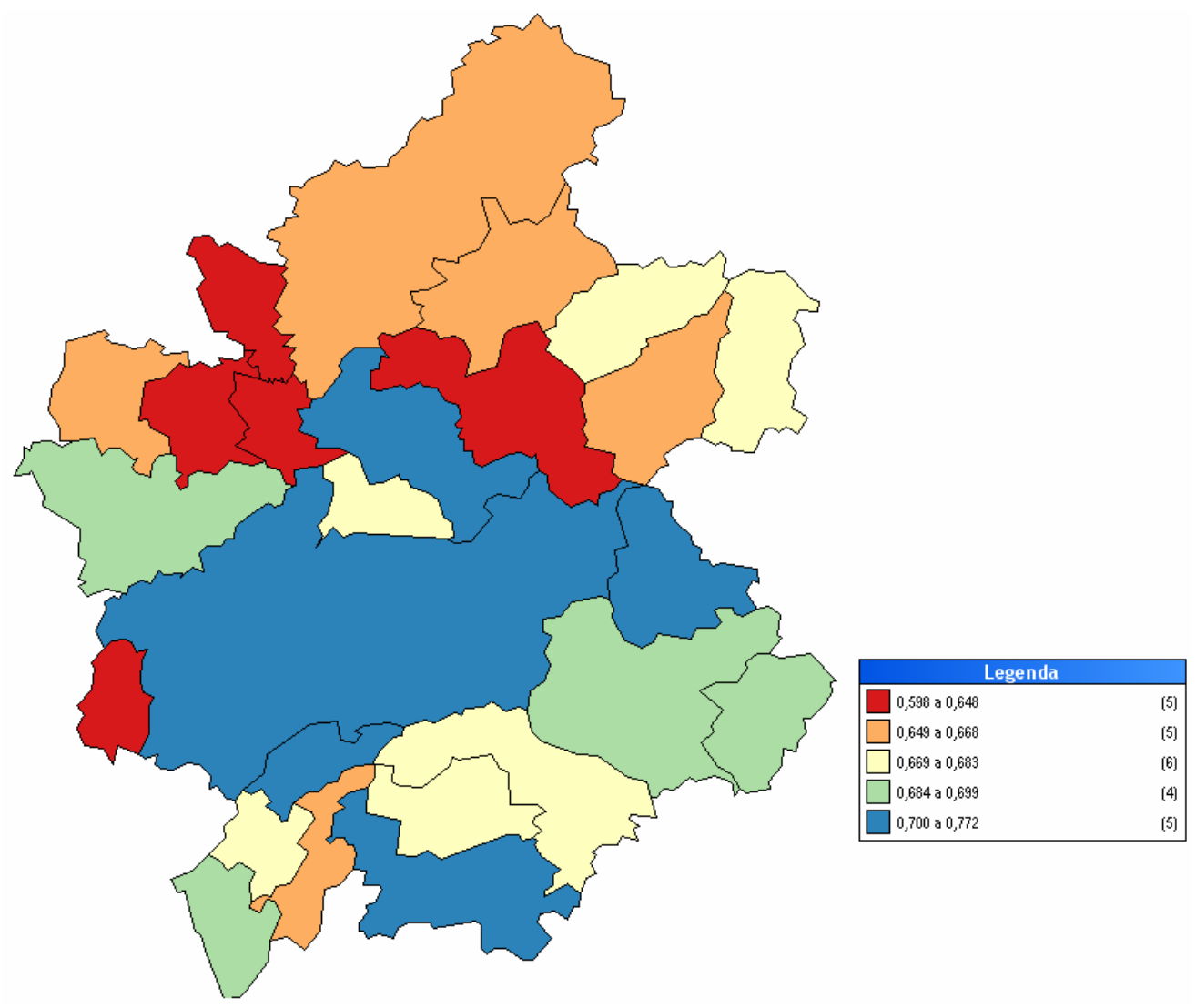

Mapa 9 - Índice de desenvolvimento humano dos municípios da microrregião de Governador Valadares/MG, 2000.

FONTE: PNUD; IPEA; FJP, 2003.

Os mapas 8 e 9 permitem ver a Microrregião e sua melhoria entre os anos de 1991 e 2000, tendo o município de Governador Valadares ao meio, em cor azul. 


\subsection{JUIZ DE FORA}

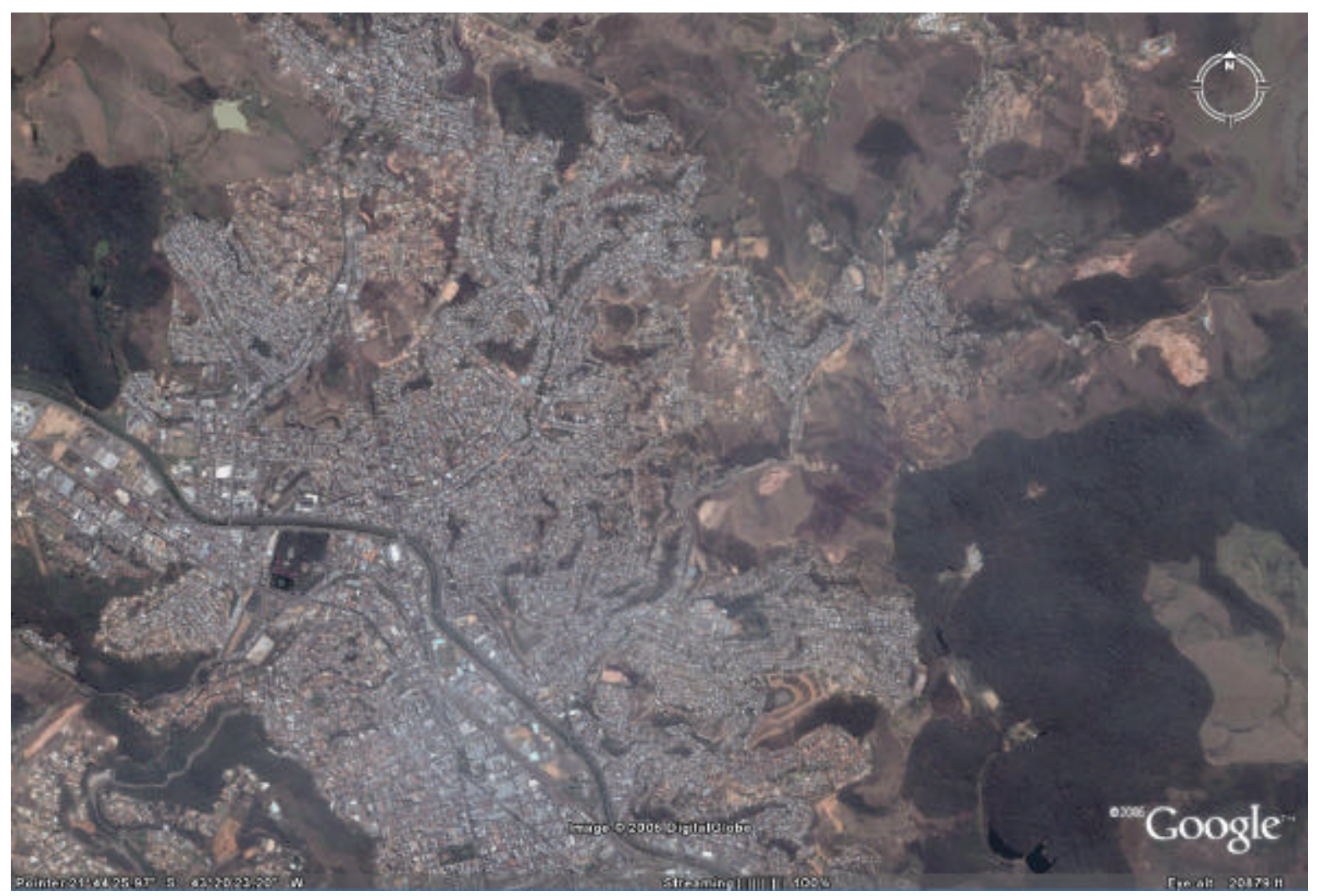

Figura 2 - $\quad$ Vista aérea de Juiz de Fora/MG (altitude 6,36 km).

FONTE: Google Earth; Europa Technologies, Digital Globe. Image @, 2006.

A história de Juiz de Fora iniciou-se com a abertura de estradas de ligação entre o litoral e o interior do país, no século XVIII, para dar escoamento a produção extrativista mineral do estado de Minas Gerais. As portas abertas pela exploração aurífera, permitiram a expansão da pecuária pelo interior de Minas. Já a expansão do café na região veio do transbordamento da atividade no vale do rio Paraíba do Sul no século XIX., cuja bacia compreende áreas dos estados de São Paulo e Rio de Janeiro. A construção da estrada do Paraibuna, que ligava Vila Rica ao Rio de Janeiro foi determinante para a expansão e polarização do município. 


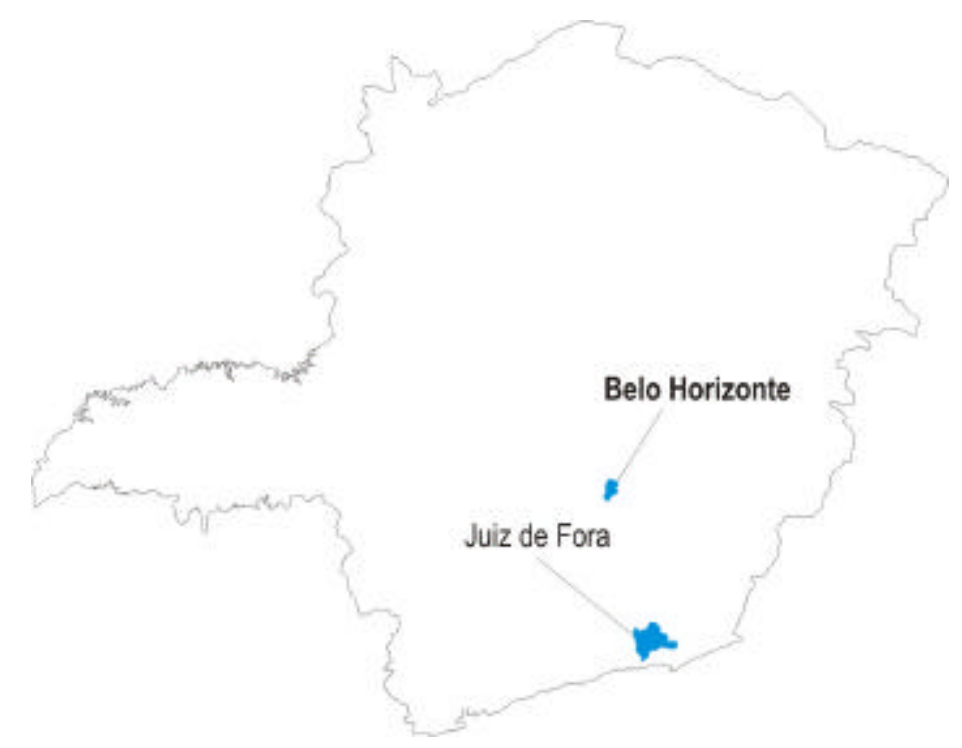

Mapa 10 - $\quad$ Situação de Juiz de Fora/MG no Estado, distante 278 km de Belo Horizonte.

FONTE: IGA, 1999.

O rio homônimo, o rio Paraibuna foi de grande importância na ocupação da

cidade de Juiz de Fora ${ }^{34}$. Sua imagem pode ser vista na foto da página anterior,

marcando um vetor no sentido sudeste-noroeste. Pela sua presença, deu-se um

desenvolvimento quase linear de ocupação da cidade.

34 O "CAMINHO NÔVO", iniciado por Garcia Rodrigues Pais em 1701 e concluído por Domingos Rodrigues Fonseca, ligando a Borda do Campo à Raiz da Serra, foi o primeiro passo para a rápida comunicação da corte com as Minas Gerais. As primeiras notícias a esse respeito podem ser encontradas no livro Cultura e Opulência do Brasil, de Antonil (1705/8), onde se lê minuciosa exposição sobre as pousadas existentes. Grande parte do território citado nessa obra iria, mais tarde, fazer parte do atual município. Ao longo do caminho distribuir-se-iam vendas e roças, entre as quais a tradição arrola como importante as de Garcia Rodrigues, em Paraibuna. Pouco tempo depois de concluída a picada (1714), o governador Brás Baltazar da Silveira, naturalmente para facilitar o desenvolvimento das terras dividiu a região em quatro comarcas: a de Vila Rica de Ouro Preto, a de Vila Real de Sabará do Rio das Velhas, a de Serro frio e a do Rio das Mortes. Esta última abrangia toda a extensão de terras desde Paraopeba e Congonhas, rumo do sul, até Paraibuna e a Serra da Mantiqueira. Apesar de tudo, a medida parece não ter atingido o objetivo, pois Alexandre Caldcleug, um século depois, esclarecia que a localidade tinha duas ou três choças apenas. SaintHilaire, todavia, escrevendo sobre as províncias do Rio de Janeiro e Minas Gerais em 1816/7, já descreve uma fazenda do Juiz de fora, que é elemento importante nos primórdios do povoado. Essa mesma propriedade, na antiga estrada do Piau, por falecimento dos Tostes (1841) foi desmembrada e partilhada entre os herdeiros; um destes, Dona Cândida Maria Carlota, casada com 0 engenheiro Henrique Guilherme Fernando Halfeld, que construiu a Estrada Nova, vendeu a prestações parte do que the coubera, concorrendo para o aumento do povoado, que do alto da Boiada se foi transferindo para a Vargem da Fazenda. Em 1850 foi criado o município e três anos depois instalada a vila, que teve o nome de Santo Antônio de Paraibuna, pois anteriormente os Tostes haviam doado terrenos destinados a construção de uma igreja sob essa invocação. 0 topônimo se reduziu a Paraibuna, quando da elevação da vila à categoria de cidade, em 1856, e só mudando para Juiz de Fora em 1865. Assinale-se que há controvérsias de ordem histórica entre os estudiosos: não quanto à origem do termo, pois é evidente que a denominação está ligada ao primeiro magistrado - juiz-de-fora - que fundou sua fazenda naquela paragem, mas quanto à identificação desse juiz. Posteriormente, com a abertura da estrada de rodagem União e Indústria (1855-1861) por Mariano Procópio Ferreira Lage, o transporte tornou-se mais fácil, contribuindo decisivamente para o progresso do município. Paralelamente, cumpre mencionar as iniciativas de Bernardo Mascarenhas, como incentivador da indústria e introdutor da luz elétrica na cidade (1889). Deve-se a esse impulso a transformação de Juiz de Fora num dos principais centros econômicos e sociais do estado, verdadeira metrópole, progressista em todos os sentidos. (IBGE, 1983). 
Sua principal atividade econômica, motivo do estabelecimento e ampliação do seu tecido urbano, foi definitivamente determinada pela influência da cidade do Rio de Janeiro sobre ela como dinamizadora do seu crescimento, uma vez que Juiz de Fora serviria como entreposto para mercadorias rumo ao porto do Rio, o que possibilitou também a articulação de serviços de abastecimento de produtos agrícolas e de pecuária leiteira.

No final do Império, a lavoura cafeeira deu lugar à industrialização, mas que se desenvolveu com uma baixa capacidade de captação de recursos, o que acabou dando lugar à prestação de serviços como sua principal atividade econômica. A riqueza produzida pelo café foi responsável pelo reequilíbrio das finanças mineiras, possibilitando a expansão da burocracia e dos serviços públicos. (PREFEITURA..., 2002).

Favorecida pela posição geográfica e pelos moldes agro-exportadores, Juiz de Fora conseguiu garantir a centralização de recursos e investimentos, tais como a implantação da primeira Usina Hidrelétrica da América do Sul no Rio Paraibuna para atendimento primordial ao setor industrial. O crescimento populacional acompanhou o progressismo industrial ocorrido até os anos de 1930.

Nos anos de 1950, a abertura de uma grande quantidade de vias de articulação nacional, acabaram por ofuscar a cidade no seu papel de centralidade frente às articulações viárias. Contribuíram para isto a abertura da rodovia RioBahia, Rio-Belo Horizonte e a articulação direta com São Paulo-Belo Horizonte, que não era mais necessariamente feita através da Zona da Mata Mineira.

Até 1960, Juiz de Fora cumpria o papel de uma capital regional. Em 1970, o de centro regional e a partir de 1980, alcançou o status de centro sub-metropolitano em posição subordinada apenas aos centros metropolitanos do Rio de Janeiro e Belo Horizonte. Em 1980, 42\% da população residente na cidade tinha origem em 
outras cidades, com predominância de cidades do estado de Minas e do Rio de Janeiro.

Entretanto, a cidade não abandonou suas aspirações industrializadoras. Na década de 70 , houve a instalação de grandes projetos de siderurgia e metalurgia. Os efeitos multiplicadores, porém, não se concretizaram, haja vista que não ocorreu a esperada pulverização industrial de suporte a novos estabelecimentos. Atualmente, o Município ensaia mais uma realização, com a expectativa de redirecionamento de sua industrialização através do ramo automobilístico. (PMJF, 2002).

\section{Quadro 13 - Microrregião de Juiz de Fora/MG.}

\begin{tabular}{l|l} 
Macrorregião & Mata \\
\hline Microrregião & Juiz de Fora \\
\hline Municípios & Aracitaba, Belmiro Braga, Bias Fortes, Bicas, Chácara, Chiador, Coronel Pacheco, Descoberto, \\
& Ewbank da Câmara, Goianá, Guarará, Juiz de Fora, Lima Duarte, Mar de Espanha, Maripá de \\
& Minas, Matias Barbosa, Olaria, Oliveira Fortes, Paiva, Pedro Teixeira, Pequeri, Piau, Rio Novo, Rio \\
& Preto, Rochedo de Minas, Santa Bárbara do Monte Verde, Santa Rita de Jacutinga, Santa Rita do \\
& lbitipoca, Santana do Deserto, Santos Dumont, São João Nepomuceno, Senador Cortes, Simão \\
& Pereira
\end{tabular}

FONTE: ALMG, 2006.

A cidade destaca-se como centro da Meso-região da Zona da Mata, com 82 municípios em sete microrregiões, segundo o IBGE. Esta centralidade está alicerçada na infra-estrutura viária e nos equipamentos urbanos de comércio e serviços.

Foi importante para o crescimento de sua população a migração ocorrida no período de 1970 a 1980, provavelmente ocorrido devido às políticas de desconcentração das metrópoles nacionais, conforme explicitado no II PND. A cidade também continua sendo um importante ponto de articulação de vias de transporte, rodoviárias e ferroviárias.

Segundo o relatório da FAUUSP (1984, p. 74):

No PNCCPM Juiz de Fora só participou de um único convênio - o de número 32/78; por ele a aplicação total seria da União através do FNDU/FDTU no total de dez milhões de cruzeiros a serem aplicados em infra-estrutura e transportes, em dois grandes projetos: a duplicação da ponte Pedro Marques e a elaboração do plano de programação visual. (FAUUSP, 1984, p. 74). 
Tabela 6 - Investimentos urbanos por fonte em Juiz de Fora/MG. Recursos em Cr\$1.000,00 - 1978/1979 (1ํ semestre).

\begin{tabular}{|c|c|c|c|c|c|c|}
\hline \multirow[b]{2}{*}{ Projetos } & \multirow[b]{2}{*}{ Órgão Executor } & \multirow[b]{2}{*}{ Município } & \multirow[b]{2}{*}{ Estado } & \multicolumn{2}{|c|}{ União } & \multirow[b]{2}{*}{ Total } \\
\hline & & & & $\begin{array}{c}\text { FNDUI } \\
\text { FDTU }\end{array}$ & $\begin{array}{c}\text { FNDUI } \\
\text { OP }\end{array}$ & \\
\hline Infra-estrutura Viária e Transportes & & & & $10.000,0$ & & $10.000,0$ \\
\hline Elaboração do plano de programação visual & Prefeitura Municipal & & & $1.843,9$ & & $1.843,9$ \\
\hline Duplicação da Ponte Pedro Marques & Prefeitura Municipal & & & $7.862,5$ & & $7.862,5$ \\
\hline $\begin{array}{lcrr}\text { Desapropriação } & \text { na interseção } & \text { da } & \text { Rua } \\
\text { Benjamim Constant com Roberto Barros } & \\
\end{array}$ & & & & 293,6 & & 293,6 \\
\hline TOTAL & & & & $10.000,0$ & & $10.000,0$ \\
\hline
\end{tabular}

FONTE: Programa de Investimentos Urbanos para Capitais e Cidades de Porte Médio, Estado de Minas Gerais.

Juiz de Fora foi escolhida como uma das quatro primeiras cidades a integrar o projeto especial do programa Cidade Porte Médio/Banco Internacional de Reconstrução e Desenvolvimento (CPM/BIRD), em 1979. Neste programa, de centros intermediários de origem estadual, foi duplicada a ponte Pedro Marques e feitas melhorias físicas no Plano de Ação Imediata de Transporte e Trânsito (PAITT).

O PROECI não incorporou Juiz de Fora entre suas cidades, pela presença do programa Cidade Porte Médio/Banco Internacional de Reconstrução e Desenvolvimento (CPM/BIRD).

O mapa 11 e 12 mostram o crescimento do distrito sede de Juiz de Fora. A parte ocupada por este parece ser um terço da área total do município, mas é nela que concentram-se tanto as atividades quantos os diagnósticos de planejamento encontrados.

Segundo dados do Plano Diretor Municipal, a área efetivamente ocupada pela urbanização em Juiz de Fora ocupa pouco mais de $23 \%$ da área urbana legal do município, o que deixa desocupados quase $77 \%$ do espaço legalmente considerado urbano. Isto não indica que toda a mancha urbana esteja ocupada e nem homogeneamente ocupada, o que fica claro numa análise simples da distribuição demográfica intra-urbana. (PREFEITURA..., 2000). 

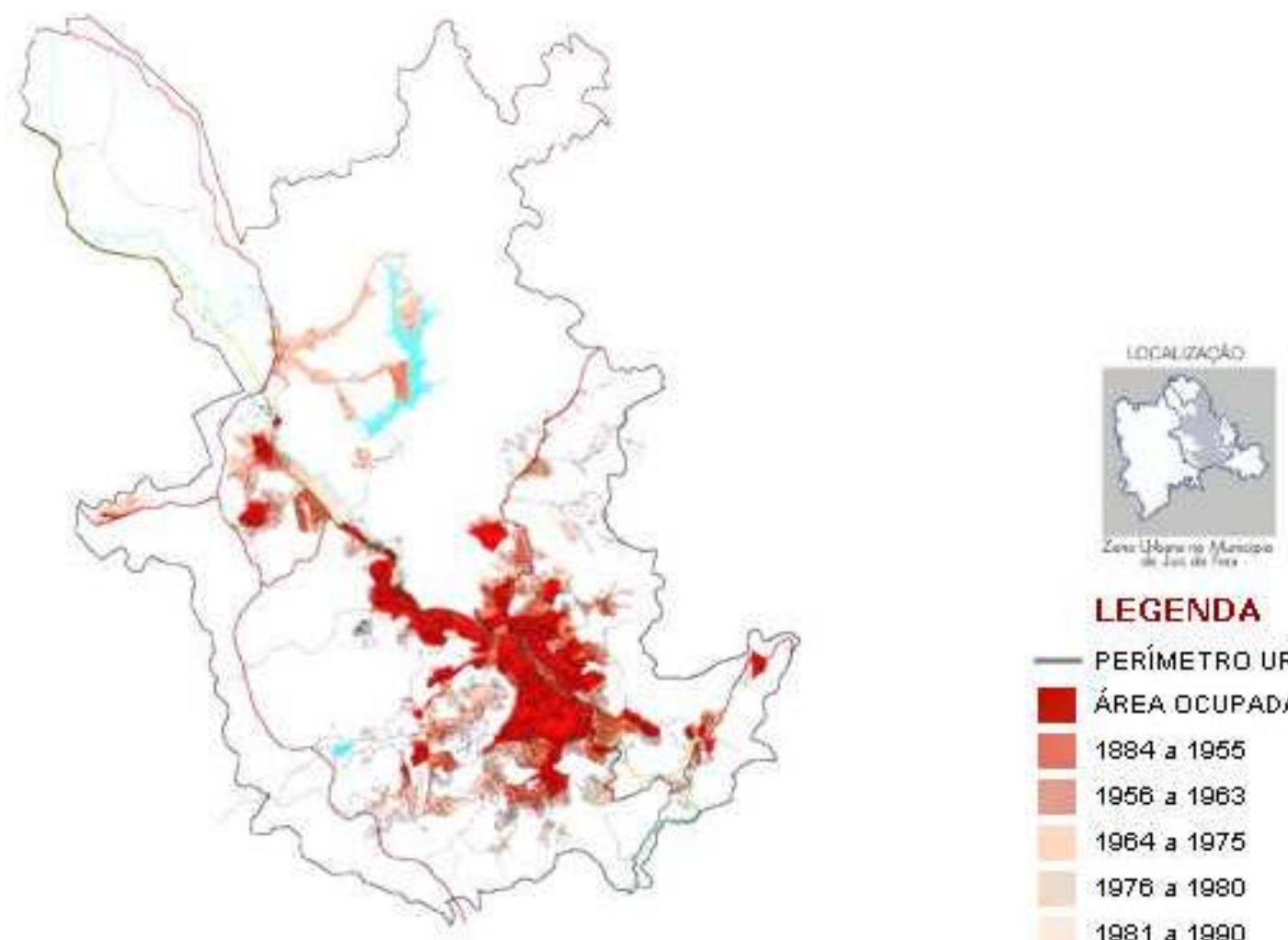

\section{LEGENDA}

- Perímetro uRBano

ÁREA OCUPADA ATÉ 1883

1884 a 1955

1956 a 1963

1964 a 1975

1976 a 1980

1981 a 1990

Mapa 11 - $\quad$ Evolução da malha urbana. Juiz de Fora/MG, 1883-1998.

FONTE: PREFEITURA... 2000.
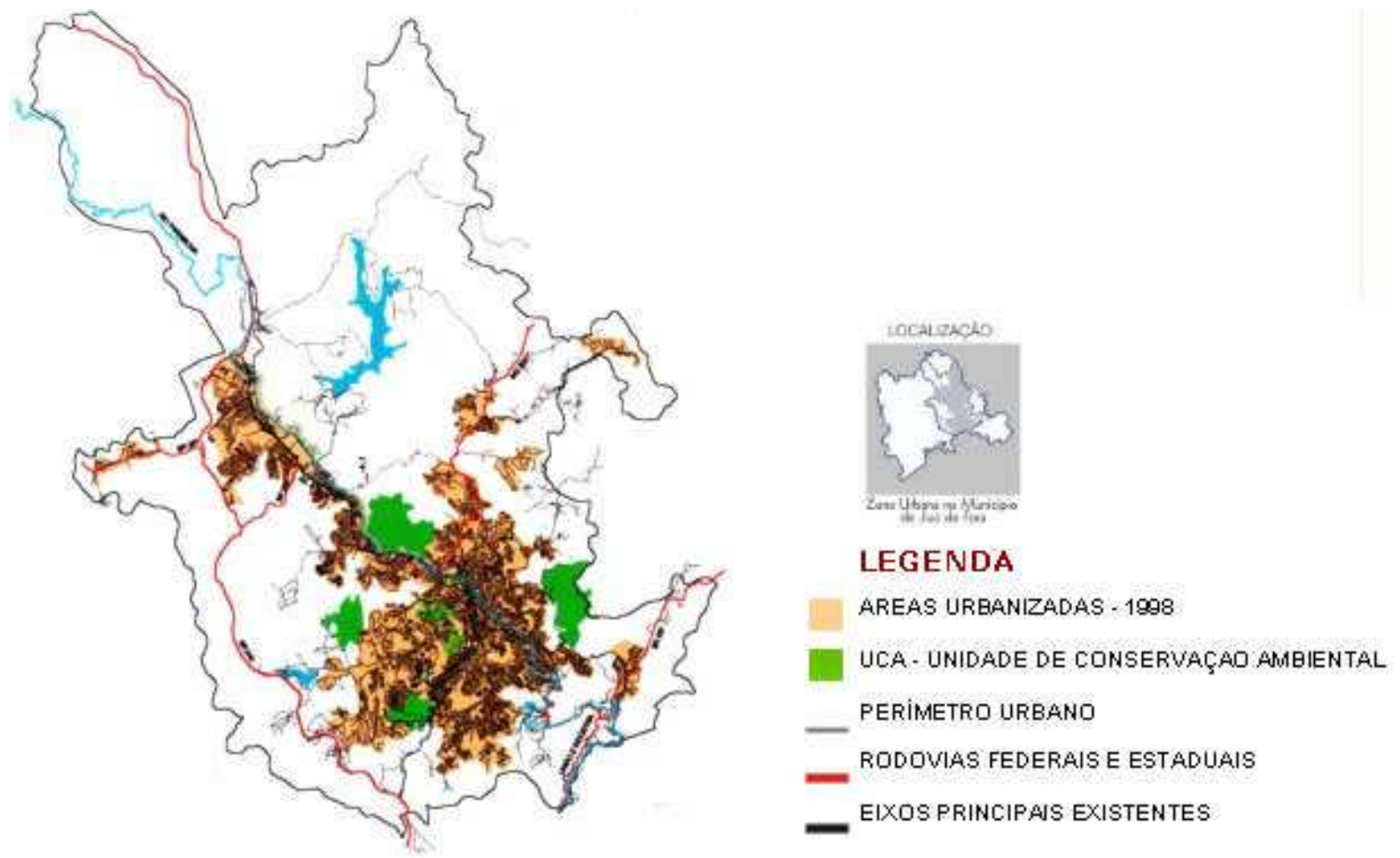

Mapa 12 - $\quad$ Malha urbana. Juiz de Fora/MG, 1998.

FONTE: PREFEITURA..., 2000. 
Para fins de planejamento, a cidade foi dividida em 12 Regiões de Planejamento e cada uma desta, em quantas unidades de planejamento fossem necessárias para uma caracterização precisa por área. Os eixos de crescimento de população de mais baixa renda foram identificados nas direções leste, sudeste, enquanto a área sul do município é retida para classe de melhor poder aquisitivo.

O Plano Diretor aponta para a necessidade futura de adoção dos instrumentos abordados pelo Estatuto da Cidade contra a especulação imobiliária, uma vez que significativa a retenção imobiliária para fins especulativos no município. Assim, o plano elenca alguns dos instrumentos do Estatuto da Cidade contra especulação imobiliária, tais como a transferência do potencial construtivo, parcelamento e edificação compulsórios; imposto territorial progressivo sobre a propriedade territorial urbana; concessão onerosa do direito de construir (solo criado); criando também outros, como o imposto regressivo sobre a propriedade territorial urbana. (PREFEITURA..., 2000).

Outra questão salientada no Plano é aquela que caracteriza o meio físico da cidade. Além de possuir um relevo acidentado, a cidade possui alguns tipos de recursos minerais, com a mica, que conduzem uma grande vulnerabilidade do solo. Juntando-se as características de solos vulneráveis e uma grande quantidade de terras retidas para valorização imobiliária, vislumbra-se a presença de abertura de loteamentos para expansão urbana em áreas pouco adequadas, contribuindo para a determinação de um quadro insustentabilidade urbana no ambiente para o município. (PREFEITURA..., 2000).

Tabela 7 - $\quad$ População do município de Juiz de Fora/MG por ocasião dos Censos Demográficos de 1950 a 1991.

\begin{tabular}{c|c|c|c|c|c}
\hline Ano & 1950 & 1960 & 1970 & 1980 & 1991 \\
\hline População & 114.531 & 169.440 & 238.510 & 307.525 & $-6,20$ \\
\hline
\end{tabular}

FONTE: Censos demográficos de 1950 a 1991. 
Será apresentada no quadro 14 a Matriz de Indicadores aplicada ao caso de Juiz de Fora.

Também para a cidade de Juiz de Fora pode ser constatada uma ascensão de qualidade do ambiente urbano, tomando por base a última coluna da matriz, que para o ano de 2000, que apresenta uma apreciação de valoração superior a 50\%.

Na categoria 1 - 'Abastecimento domiciliar de água', pode-se também dizer que houve melhoria no período de incidência das políticas públicas e seus investimentos, em percentuais bem menores do que os de Governador Valadares. Dos anos 1970 para os anos 1990, o aumento de famílias abastecidas por água da rede geral de abastecimentos foi de $31,0 \% \%$, enquanto o crescimento do número de famílias do município aumentou duas vezes. Em 1990, chega-se a um atendimento de $92,4 \%$ da população. Mas o grande crescimento relativo deste serviço se deu entre as décadas de 80 e 90, quando provavelmente os investimentos já haviam ocorrido em sua maioria. A 'Coleta de água servida', apresentada pela categoria 2'Saneamento básico', tem uma melhora no mesmo período, passando a abranger cerca de $90 \%$ das famílias na década de 1990, tendo começado com um horizonte de $61,3 \%$ das famílias nos anos de 1970, o que é um patamar significativamente melhor do que o observado para Valadares. No período compreendido entre os anos 70 e 90, foi quando da maior proporção de domicílios com melhoria de acesso ao saneamento para este caso, sendo de cerca de $34,9 \%$.

Os dados para o ano de 2000 revelam uma adequada qualidade ambiental para os parâmetros adotados por este trabalho, pois ambos, abastecimento de água e coleta de esgoto apresentam valores relativos superiores a $75 \%$, conforme estabelecido na metodologia deste trabalho. 
Quadro 14 - Matriz de Indicadores de Qualidade de Vida Urbana - Juiz de Fora - Matriz com o total dos indicadores.

\begin{tabular}{|c|c|c|c|c|c|c|c|}
\hline 2 & \multicolumn{2}{|c|}{\begin{tabular}{|r} 
\\
\end{tabular}} & 1960 & 1970 & 1980 & 1990 & 2000 \\
\hline \multirow{2}{*}{ 1. Abastecimento domiciliar de água } & \multirow{2}{*}{\multicolumn{2}{|c|}{\begin{tabular}{|l} 
Acesso à água potável \\
Proporções de domicílios com melhoria de acesso ao abastecimento de água
\end{tabular}}} & $61,77 \%$ & $61,31 \%$ & $70,74 \%$ & 92,4 & $95,30 \%$ \\
\hline & & & & $-0,36 \%$ & $9,43 \%$ & $21,66 \%$ & $2,9 \%$ \\
\hline \multirow{7}{*}{ 2. Saneamento básico } & \multicolumn{2}{|c|}{ Coleta de água servida } & $58,68 \%$ & $55,09 \%$ & $69,9 \%$ & $90,0 \%$ & $93,25 \%$ \\
\hline & \multirow{2}{*}{\multicolumn{2}{|c|}{\begin{tabular}{|l} 
Proporçōes de domiclilios com melhoria de acesso ao saneamento \\
Proporções de domiclios com melhoria de acesso à instalaçōes sanitiárias
\end{tabular}}} & & $-3,59 \%$ & $14,81 \%$ & $20,1 \%$ & $3,25 \%$ \\
\hline & & & & & & & \\
\hline & \multicolumn{2}{|c|}{\begin{tabular}{|ll} 
Aguas residuais tratadas \\
\end{tabular}} & & - & & $1-$ & \\
\hline & \multicolumn{2}{|c|}{ Recolhimento regular de dejetos sólidos } & & & & & $98,37 \%$ \\
\hline & \multicolumn{2}{|c|}{\begin{tabular}{|l|l|} 
Adequada disposição do lixo \\
\end{tabular}} & & - & - & - & \\
\hline & \multirow{2}{*}{\multicolumn{2}{|c|}{\begin{tabular}{|l} 
Promoção integrada de infra-estrutura ambientall: água, saneamento, drenagem e manejo de resíduos sólidos \\
Percentual de populacão acima do limiar da pobreza
\end{tabular}}} & & & & & \\
\hline \multirow{10}{*}{ 3. Habitação } & & & & & $97,8 \%$ & & $89,47 \%$ \\
\hline & \multicolumn{2}{|c|}{\begin{tabular}{|l|l|l|l|l|l} 
Percentual de população acima do limiar da pobreza \\
A Area suficieinte para viver
\end{tabular}} & & - & & - & \\
\hline & \multirow[t]{2}{*}{ Densidade } & Proporção de domicililios com menos de três pessoas por cômodo & & & & & $75,02 \%$ \\
\hline & & Utilização materiais permanentes que propiciem uma habitação segura e duradoura & - & $84 \%$ & $91 \%$ & $67,21 \%$ & \\
\hline & \multirow[t]{2}{*}{ Benfeitoria } & \begin{tabular}{|l} 
Conexões hidro-sanitárias internas ao domicílio \\
\end{tabular} & & & & & $99,6 \%$ \\
\hline & & Construída fora de áreas de risco & & & & & \\
\hline & \multirow{4}{*}{ Posse } & Habitação cuja ocupação esteja assegurada & & $47 \%$ & $48 \%$ & $36,08 \%$ & $65,47 \%$ \\
\hline & & Financiamento de habitações & & & & & \\
\hline & & Relação preço da terra versus ingresso no mercado de terra & & & & & \\
\hline & & Preço da habitação e coeficiente de habitações ingressadas no montante total & & & & & \\
\hline \multirow{5}{*}{ 4. Desenvolvimento técnico-tecnológico } & \multicolumn{2}{|c|}{ Aperfeiçoados o manejo dos assentamentos humanos } & - & - & - & - & - \\
\hline & \multirow{2}{*}{\multicolumn{2}{|c|}{ 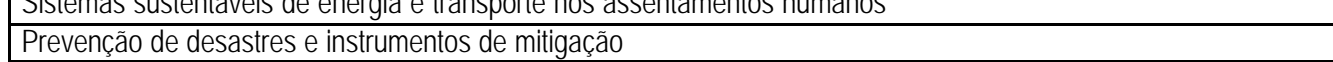 }} & & - & - & - & 4 \\
\hline & & & - & - & - & - & - \\
\hline & \multicolumn{2}{|c|}{ Atividades sustentáveis na indústria da construção } & & & & & - \\
\hline & \multicolumn{2}{|c|}{ Capacitaçẫo institucional e técnica para o avanç̧o dos assentamentos humanos } & & $5^{-}$ & - & - & - \\
\hline \multirow{2}{*}{\begin{tabular}{|l|} 
5. Infra-estrutura viária \\
6. Existência de áreas verdes suficientes
\end{tabular}} & \multirow{2}{*}{\multicolumn{2}{|c|}{\begin{tabular}{|l|} 
Modos de transporte \\
Sistemas sustentáveis de transporte
\end{tabular}}} & & & & & \\
\hline & & & & & & & - \\
\hline \multicolumn{3}{|c|}{ 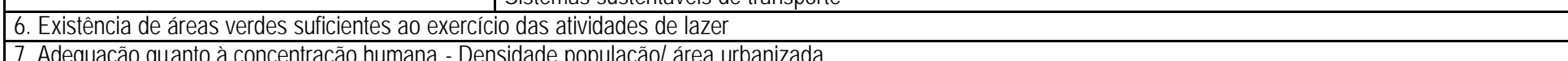 } & - & - & - & - & - \\
\hline \multicolumn{3}{|c|}{ 7. Adequação quanto à concentração humana - Densidade populaçãolálárea urbanizada } & - & - & F & - & 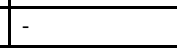 \\
\hline \multicolumn{8}{|c|}{\begin{tabular}{|l|l} 
Densidade do município & 3,1 hab/ha \\
\end{tabular}} \\
\hline \multirow{2}{*}{\multicolumn{2}{|c|}{\begin{tabular}{|l|} 
Tamanho da populaçã̃o \\
Número de famílias \\
\end{tabular}}} & 175.455 & & 385.996 & & 456.796 & \\
\hline & & 48.011 & & 100.388 & & 132.465 & \\
\hline
\end{tabular}

\section{Quadro 15 - Matriz de Indicadores de Qualidade de Vida Urbana - Juiz de Fora - 1ª ordenação dos dados}

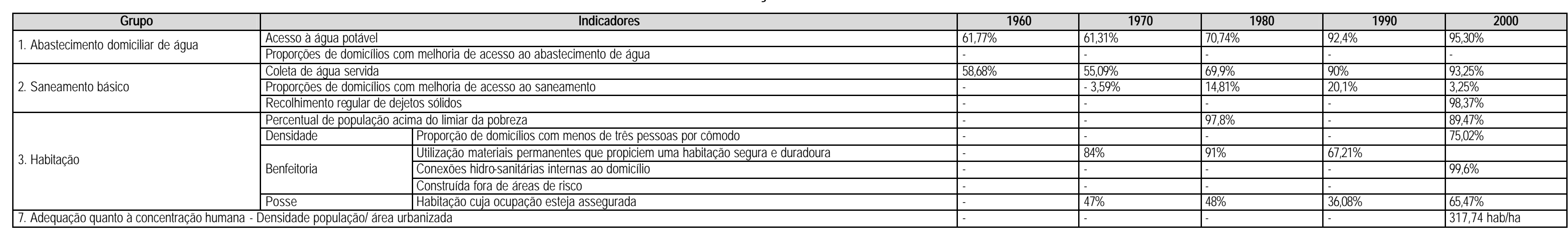

\section{Quadro 16 - Matriz de Indicadores de Qualidade de Vida Urbana - Juiz de Fora - composição tonal}

\begin{tabular}{|c|c|c|c|c|c|c|}
\hline Grupo & Indicadores & 1960 & 1970 & 1980 & 1990 & 2000 \\
\hline 1. Abastecimento domiciliar de água & Acesso à água potável & & & & & \\
\hline \multirow{2}{*}{ 2. Saneamento básico } & Coleta de água servida & & & & & \\
\hline & \multirow{2}{*}{\begin{tabular}{|l} 
Recolhimento regular de dejetos sólidos \\
Percentulalde ponulacão acima dolimiar da nobreza
\end{tabular}} & & & & & \\
\hline \multirow{5}{*}{ 3. Habitação } & & & & & & \\
\hline & \begin{tabular}{l|l} 
Proporção de domicilios com menos de três pessoas por cômodo \\
\end{tabular} & - & & & & \\
\hline & \begin{tabular}{|l} 
Utilização materiais permanentes que propiciem uma habitação segura e duradoura \\
\end{tabular} & & & & & \\
\hline & Conexõ̃es hidro-sanitárias internas ao domicílio & & & & & \\
\hline & Habitação cuja ocupação esteja assegurada & & & & & \\
\hline
\end{tabular}


Devidamente considerado deve ser o fato da inexistência de uma série histórica de informações para o dado de recolhimento regular de dejetos sólidos. Este dado só está presente para 2000, apresentando 98,3\% das famílias.

Para a categoria 3 - 'Habitação', alguns dados estão presentes, sendo aqui elucidados. O percentual de população acima do limiar da pobreza está presente para os anos de 1980 e 2000, havendo uma diminuição relativa nesses 20 anos. Em 1980, eram $97,8 \%$ da população reduzindo-se a $89,4 \%$ em 2000 . Estes números possivelmente apontam para o mesmo caráter de empobrecimento geral da população do município e do país, apontado anteriormente.

Os números de habitações cuja benfeitoria foi feita utilizando 'materiais permanentes que propiciem uma habitação segura e duradoura' tem nos anos 1980 o maior número de famílias com acesso ao tipo de benfeitoria colocado, ou seja, $92,1 \%$. O período anterior, na década de 1970 , tem-se $84 \%$ e no imediatamente posteriores, a década de 1990 , em torno de $70 \%$ do total de famílias.

Também para a categoria 'Posse' fica claro serem os anos 1980 o melhor desempenho do indicador 'Habitação cuja ocupação esteja assegurada', antes do período de 2000. Em 1980 o valor era de 48\% e em 2000, 65,4\%.

$\mathrm{Na}$ categoria 7 - Adequação quanto à concentração humana - densidade população área urbanizada, não foi possível obter esta informação para o município. Já a densidade total do município, considerando-se a área total do município $1439,1 \mathrm{~km}^{2}$ e sua população de 456.796 , tem-se uma densidade 3,2 hab/ha. Em relação ao estabelecido por Dias (2002), a área disponível por habitante no planeta é hoje um hectare para cada habitante. O município encontra-se com uma densidade bem acima da estabelecida.

A Matriz de Qualidade de Ambiente Urbano - Composição Tonal permite que seja percebida a totalidade das informações, apenas qualitativamente. Percebe-se 
do lado direito do quadro a melhora da qualidade ambiental, sendo que toda a última coluna, referente ao ano de 2000, apresenta dados mais adequados à constituição de um ambiente urbano sustentável, conforme parâmetros necessários consolidados pela matriz. Mas a situação de adequação do município só possui parâmetros considerados de 'baixa a média' qualidade de ambiente urbano no indicador que se refere à posse segura, que demonstra elevada concentração fundiária e exclusão sócio-espacial.

Considerando que foi possível obter apenas 21 dados dos 140 que foram propostos para a matriz total ${ }^{35}$, tem-se uma estatística que não chega a ser determinante da sustentabilidade do ambiente da cidade, pois 21 dados obtidos correspondem a 15\% do total considerado necessário para análise do município.

Para o caso de Juiz de Fora, 19 dos dados estão classificados como estando entre as classes 'média' e 'adequada qualidade' do ambiente urbano, o que equivale a $13,6 \%$ do total, e dentre estes 19 , apenas 10 dos elementos levantados estão classificados como 'adequada' qualidade do ambiente urbano.

Considerando o universo total como sendo o dos 21 dados obtidos, a sustentabilidade pode ser mais facilmente aceita. Sendo 19 o número de dados entre as classes 'média' e 'adequada qualidade' do ambiente urbano, tem-se 90,5\% e quanto aos 10 dos elementos classificados como 'adequada qualidade' do ambiente urbano, tem-se $47,6 \%$ dos dados.

Sendo que o diferencial na qualidade do ambiente no município estabelecido pela matriz está em período anterior e posterior às políticas públicas, pode-se referenciar que elas sejam pouco motivadoras da qualidade do ambiente.

\footnotetext{
35 A matriz é composta por 28 indicadores que são apresentados para cada um dos cinco períodos de tempo analisados. Assim sendo, a totalidade de indicadores para os cinco períodos é de 140 itens sendo analisados.
} 
Ressalta-se ainda, que o PROECI não atuou no município, o que pode ser considerado também como um fator relevante para que os dados intermediários não tenham sido tão ampliados em relação aos iniciais, como se deu em Governador Valares.

De uma forma bem mais sutil do que o município anterior, pode-se considerar que Juiz de Fora tende a uma adequação da qualidade do ambiente urbano, sendo que seu patamar inicial era bem melhor do que o de Valadares e que o final também, em relação a todos os indicadores levantados.

Outros dados que auxiliam na análise do município são expostos a seguir. A renda per capta média do município cresceu $34,58 \%$, passando de $R \$ 311,64$ em 1991 para $\mathrm{R} \$ 419,40$ em 2000. A pobreza (medida pela proporção de pessoas com renda domiciliar per capta inferior a $R \$ 75,50$, equivalente à metade do salário mínimo vigente em agosto de 2000) diminuiu 33,05\%, passando de 21,1\% em 1991 para 14,1\% em 2000. A desigualdade cresceu: o Índice de Gini passou de 0,57 em 1991 para 0,58 em 2000. (PREFEITURA..., 2000).

Considerando também algumas informações sobre indicadores apresentadas pelo IDH-Municipal (PNUD; IPEA; FJP, 2003):

No período 1991-2000, o índice de Desenvolvimento Municipal (IDHM) de Juiz de Fora cresceu 7,67\% passando de 0,769 em 1991 para 0,828 em 2000.

A dimensão que mais contribuiu para este crescimento foi a Longevidade, seguida pela Educação e pela Renda (...).

Se mantivesse esta taxa de crescimento do IDH, o município levaria 12,2 anos para alcançar São Caetano do Sul (SP), o município como o melhor IDH do Brasil $(0,919)$ e 1,8 anos para alcançar Poços de Caldas (MG), o município com o melhor IDH do Estado $(0,841)$.

(...) Segundo a classificação do PNUD, o município está entre as regiões consideradas de alto desenvolvimento humano (IDH maior que 0,8) (PNUD; IPEA; FJP, 2003). 
$\mathrm{Na}$ classificação exposta acima, de 'regiões consideradas de alto desenvolvimento humano' validam a análise feita dos percentuais demonstrados pela matriz da qualidade do ambiente.

As ilustrações que se seguem permitem ver a Microrregião e sua melhoria entre os anos de 1991 e 2000, tendo o município de Governador Valadares ao meio, em cor azul.
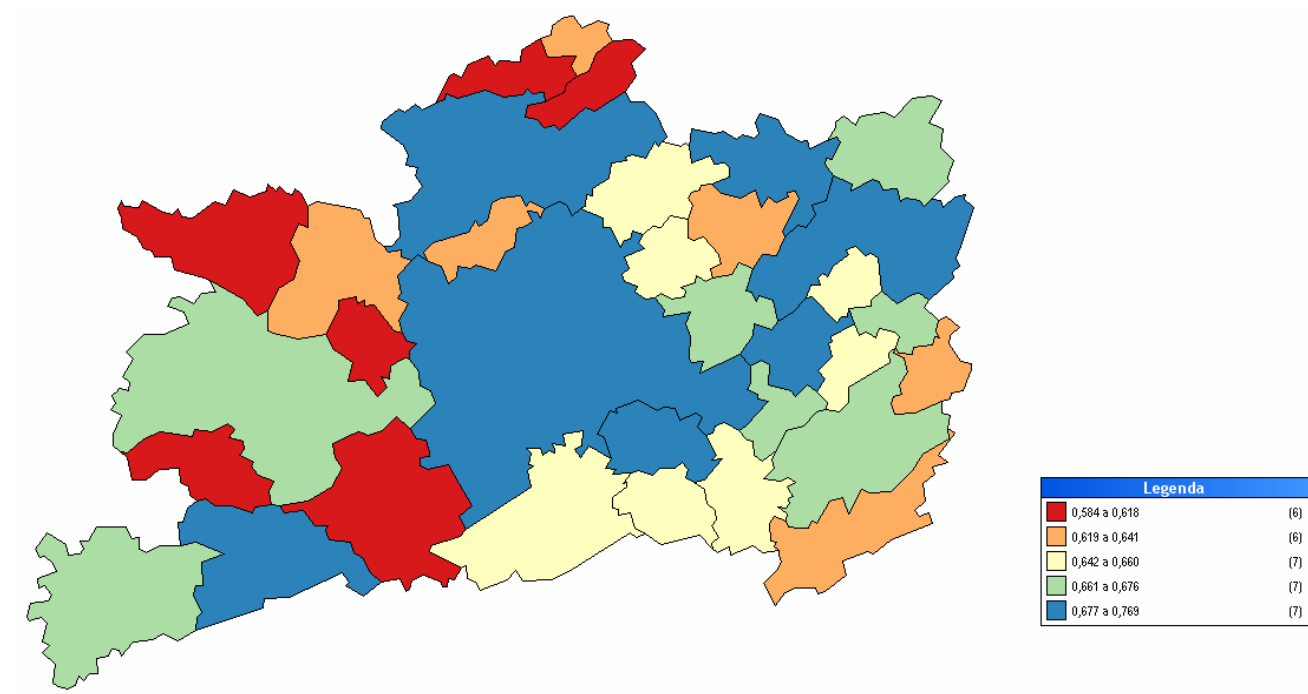

Mapa 13 -

Índice de desenvolvimento humano dos municípios da microrregião de Juiz de Fora/MG, 1991.

FONTE: PNUD; IPEA; FJP, 2003.
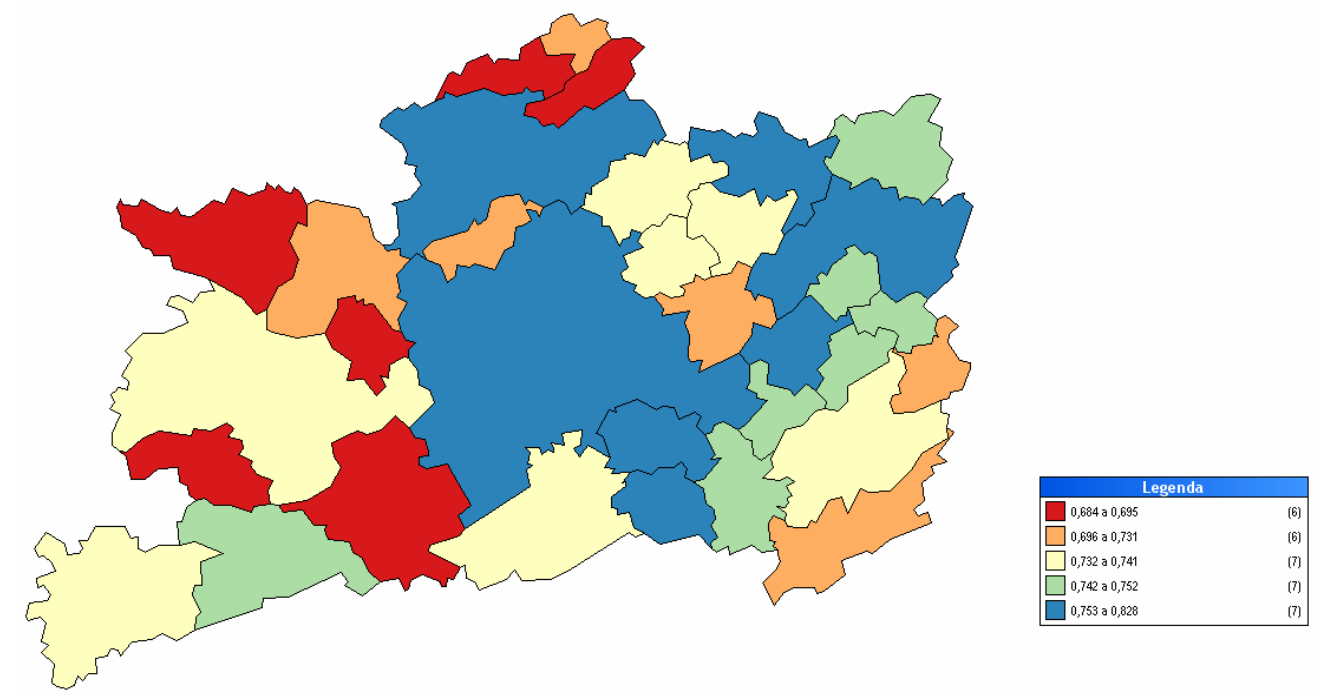

Mapa 14 - Índice de desenvolvimento humano dos municípios da microrregião de Juiz de Fora/MG, 2000.

FONTE: PNUD; IPEA; FJP, 2003. 


\subsection{MONTES CLAROS}

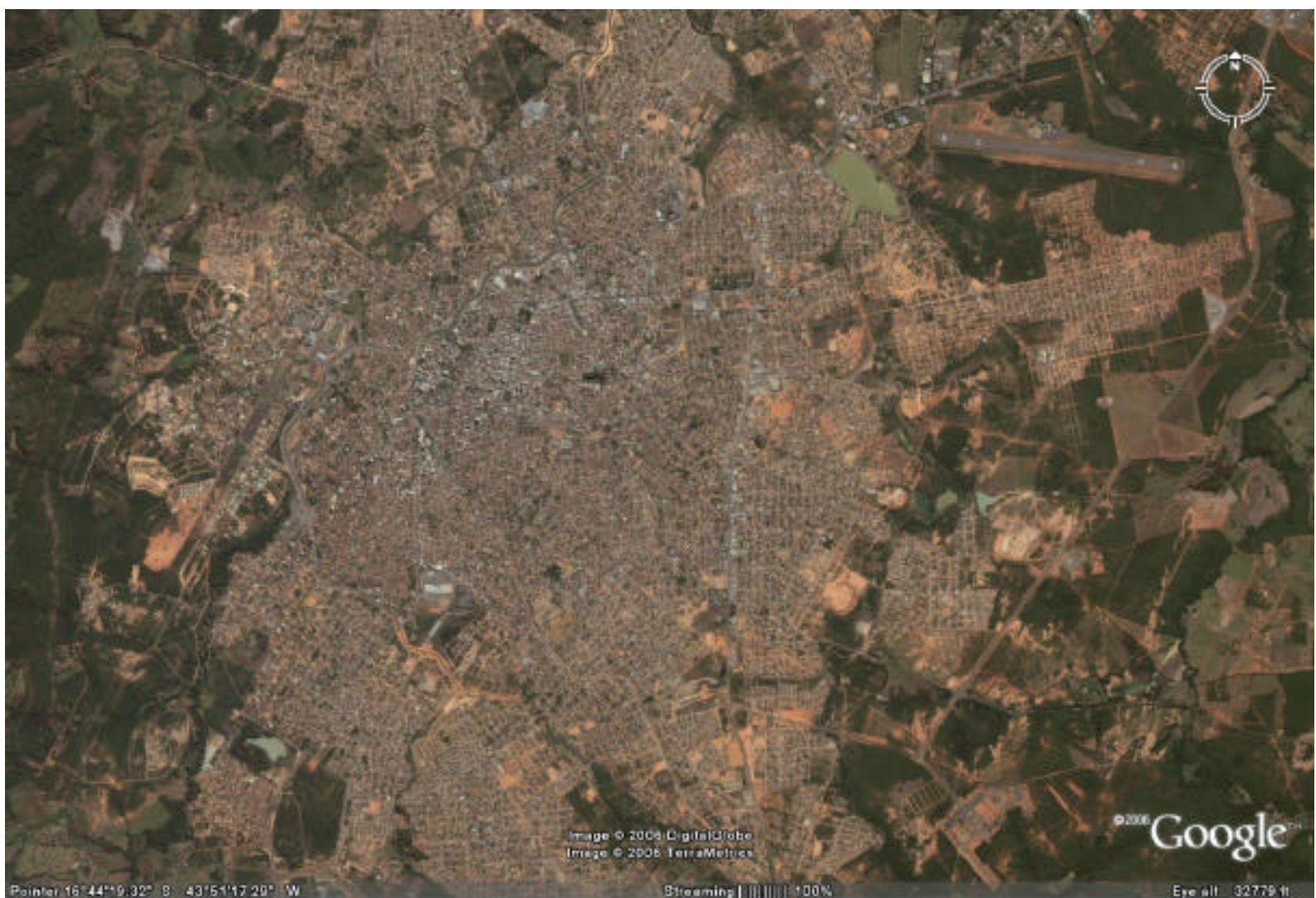

Figura 3- Vista aérea de Montes Claros/MG (altitude 9,99 km).

FONTE: Google Earth; Europa Technologies, Digital Globe. Image @), 2006.

Montes Claros $^{36}$ exerce um importante papel de ligação entre o nordeste, o

sudeste e o centro-oeste do país. Como capital regional, exerce sua influência sobre

toda a área mineira do nordeste, sendo o principal centro interno de referência para

aquela população.

36 Tal como aconteceu a inúmeros Municípios do sertão brasileiro, Montes Claros deve sua origem aos bandeirantes. Presume-se que 0 atual território desse Município tenha sido primeiramente devassado pela expedição denominada "Espinosa-Navarro", que partira de Porto Seguro a 13 de junho de 1553. Foi, no entanto, Antônio Gonçalves Figueira, expedicionário da "bandeira" de Matias Cardoso, adjunto do famoso "Governador das Esmeraldas" que era Fernão Dias Paes Leme, quem fundou Montes Claros. Após estar por algum tempo estabelecido em Ituassu, dedicando-se ao cultivo da cana de açúcar, Antônio Gonçalves Figueira lançou-se novamente à procura de metais e pedras preciosas. E foi assim que, desbravando as regiões incultas do Vale do São Francisco, fundou em princípios do século XVIII as fazendas de Jaíba, Olhos d'Água e Montes Claros. A situação desta última, à margem do Rio Verde Grande, próximo de montes calcáreos, despidos de vegetação e, por isso mesmo, sempre claros, teria sugerido o nome do atual Município. Por Alvará de 12 de abril de 1707, foram concedidas sesmarias de uma légua de largura por três de comprimento, cada uma, a Antônio Gonçalves Figueira e aos Capitães Pedro Nunes de Cerqueira, Manoel Afonso de Siqueira, João Gonçalves Filgueiras e outros. Com grande número de indígenas escravizados e, a seguir, com o escravo negro, procedeu-se ao cultivo da terra e à criação de gado, originando-se os primeiros núcleos de população. Formou-se, então, o povoado de Formigas, onde se erigiu uma capela, sob a invocação de Nossa Senhora e São José. (IBGE, 1983). 
A partir dos anos de 1940, a cidade expande-se por ventura das migrações nordestinas que tinham a própria cidade como destino ou que almejavam, através dela, alcançar pontos mais avançados no Sudeste ou mesmo no Centro-Oeste do país.

A urbanização ampliou-se a partir dos anos de 1950 com continuidade nos anos de 1960, quando ocorreu uma grande proliferação de loteamentos, em uma ocupação caracteristicamente horizontal e de baixa densidade.

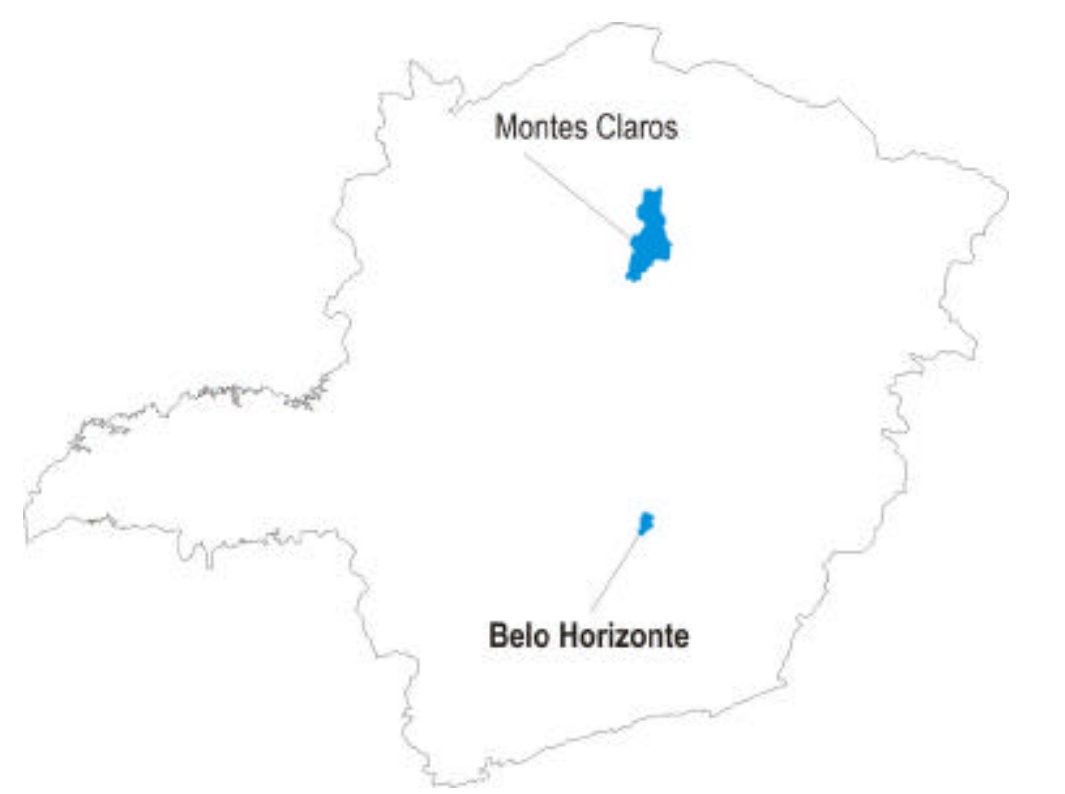

Mapa 15 - S Situação do município de Montes Claros/MG no Estado. FONTE: IGA, 1999.

Até meados dos anos de 1960, sua economia estava baseada essencialmente na agricultura e pecuária, sendo predominante a pecuária de corte e atividades agrícolas de subsistência. Com a criação da SUDENE e a incorporação de trechos do estado de Minas Gerais à sua área de atuação, foram desenvolvidos os primeiros projetos industriais. Com isto, a década de 1970 foi caracterizada pelo crescimento populacional calcado na imigração objetivada pelo emprego.

Segundo Leite e Pereira (2004) a década de 1970 constitui um importante marco na história de Montes Claros, quando do significativo processo de 
industrialização, viabilizado pelos incentivos governamentais, com grandes transformações no espaço urbano. A partir desta década, houve um significativo aumento populacional.

Ainda segundo este autor, o setor secundário passou a ter importância na composição da base econômica montes-clarense, havendo uma inversão no quadro até então existente, ou seja, a década de 1970 seria o marco da transformação de uma Montes Claro agrária, para uma Montes Claros urbano-industrial. (LEITE; PEREIRA, 2004, p. 36)

Por conseqüência ocorrem os incrementos das atividades urbanas, sendo o comércio dentro do terciário o setor de atividades que passou a oferecer uma maior quantidade de postos de trabalho. Como efeito indireto da industrialização, o comércio, que sempre foi uma atividade relevante se viu ampliando.

Segundo o relatório da FAUUSP (1984, p. 70) para o PNCCPM:

Montes Claros participou do Programa Nacional de Apoio às Capitais e Cidades de Porte Médio, através do convênio 32/78 firmado em 11/10/79. Ao município destinado um total de recursos de 156,1 milhões de cruzeiros dos quais, o próprio município apresentou a contrapartida de 55,6 bilhões, e o estado de Minas Gerais 69,5 bilhões. Cabe à União, através de recursos provenientes do FNDU/FNTU a quantia de 31 bilhões de cruzeiros. Esta última, em razão da própria fonte financiadora, destinada a aplicação em infraestrutura viária e transportes, mas especialmente no projeto de implantação da avenida Sanitária - Barroca I e Barroca II - via que, de acordo com o perfil da cidade elaborado em 1978, ligaria o centro ao Distrito Industrial passando por vários bairros carentes. (FAUUSP, 1984, p. 70).

De acordo com o relatório, o município acabaria por assumir grande parte dos custos de infra-estrutura viária, além de alguns encargos da construção de infraestrutura social, que estariam a cargo do PNCCPM. Mesmo os recursos disponíveis pelo FNTU acabariam não sendo utilizados na integra. O mesmo trabalho analisa que a intervenção do Conselho Nacional de Desenvolvimento Urbano (CNDU) acabaria não dirigindo os objetivos declarados de desconcentração industrial e 
dinamização econômica, demonstrando a fragilidade da atuação federal para a consecução dos objetivos propostos.

Tabela 8 -

Investimentos urbanos por fonte em Montes Claros/MG. Recursos em Cr\$1.000,00 - 1978/1979 (1을 semestre).

\begin{tabular}{|c|c|c|c|c|c|c|}
\hline \multirow[b]{2}{*}{ Projetos } & \multirow[b]{2}{*}{ Órgão Executor } & \multirow[b]{2}{*}{ Município } & \multirow[b]{2}{*}{ Estado } & \multicolumn{2}{|c|}{ União } & \multirow[b]{2}{*}{ Total } \\
\hline & & & & $\begin{array}{l}\text { FNDUI } \\
\text { FDTU }\end{array}$ & $\begin{array}{c}\text { FNDUI } \\
\text { OP }\end{array}$ & \\
\hline Planejamento e Administração & & & $2.145,0$ & & & $2.145,0$ \\
\hline Assessoria Técnica & $\begin{array}{l}\text { Prefeitura } \\
\text { Municipal }\end{array}$ & & $2.145,0$ & & & $2.145,0$ \\
\hline Infra-estrutura Viária e Transportes & & $42.150,0$ & $67.340,2$ & $31.021,0$ & & $140.511,2$ \\
\hline $\begin{array}{l}\text { Implantação da Avenida Sanitária - Barroca I } \\
\text { e Barroca II }\end{array}$ & $\begin{array}{l}\text { Prefeitura } \\
\text { Municipal }\end{array}$ & $5.000,0$ & $50.340,2(1)$ & $31.021,0$ & & $86.361,2$ \\
\hline Construção do Terminal Rodoviário & $\begin{array}{l}\text { Prefeitura } \\
\text { Municipal }\end{array}$ & $15.000,0$ & & & & $15.000,0$ \\
\hline Construção do Anel Rodoviário & DER & $1.150,0$ & $10.000,0(2)$ & & & $11.150,0$ \\
\hline Pavimentação de ruas e acessos aos Bairros & $\begin{array}{l}\text { Prefeitura } \\
\text { Municipal }\end{array}$ & $21.000,0$ & $7.000,0(2)$ & & & $28.000,0$ \\
\hline Infra-estrutura Social & & $13.460,5$ & & & & $13.460,5$ \\
\hline Construção do Centro Cultural & $\begin{array}{l}\text { Prefeitura } \\
\text { Municipal }\end{array}$ & $13.460,5$ & & & & $13.460,5$ \\
\hline TOTAL & & $55.610,5(3)$ & $69.485,2(4)$ & $31.021,0$ & & $156.116,7(5)$ \\
\hline
\end{tabular}

(1) Deste total Cr\$18.340,2 são recursos do IULCLG e Cr\$32.000,0 são do Tesouro do Estado de MG.

(2) Recursos de órgãos setoriais do Estado (DER).

(3) Deste total Cr\$9.610.500,0 não constam da EM 302/78 de 3/7/78.

(4) Deste total $\mathrm{Cr} \$ 14.145 .000,0$ não constam da EM 302/78 de 3/7/78.

(5) Deste total Cr\$23.755.500,0 não constam da EM 302/78 de 3/7/78.

FONTE: Convênio 82/79 do Programa de Investimentos Urbanos para Capitais e Cidades de Porte Médio, Estado de Minas Gerais.

Segundo Leite e Pereira (2004, p. 42):

A década de 1980 foi a mais importante na questão da expansão de infra-estrutura urbana na região norte, pois nessa época foi implantado o Projeto Cidade de Porte Médio, que tinha como objetivo possibilitar à população de baixa renda, especialmente a que residia em áreas invadidas ou favelas da cidade, acesso à casa própria, a serviços urbanos e de saneamento básico, bem como a legalização da posse da terra, elevando assim, a qualidade de vida dessa população.

A execução desse projeto ficou sob responsabilidade da Secretaria de Planejamento e Coordenação de Montes Claros, sendo que $70 \%$ do capital investido foi proveniente do Banco Interamericano de Reconstrução e Desenvolvimento (BIRD), 20\% do cofre do Estado de Minas Gerais e $10 \%$ da Prefeitura de Montes Claros. Parte da população das favelas dessa área foi removida e instalada no conjunto habitacional Tabajara, que estava localizado em uma área próximo ao bairro Renascença, com aproximadamente $72.700 \mathrm{~m}^{2}$, de propriedade da Prefeitura de Montes Claros. Para esse local foram transferidas 265 famílias, proveniente da região norte da cidade. As famílias que ainda ficaram nas favelas da zona norte receberam uma 
série de melhoramentos em seus lotes como saneamento básico (água, esgoto e energia elétrica), pavimentação asfáltica de ruas e a legalização da posse dos lotes. O referido projeto beneficiou também outras áreas ocupadas que não constituíram favelas através da ampliação de infra-estrutura urbana. (...) Também a região sul da cidade foi beneficiada com o Projeto Cidade de Porte Médio, quando ocorreram algumas mudanças na infra-estrutura como pavimentação de ruas e avenidas, construção de posto de saúde e praça de lazer, obras que fizeram com que essa área fosse valorizada. (LEITE; PEREIRA, 2004, p. 42)

Já a Prefeitura assumiria diversos programas nas áreas de infra-estrutura viária e transportes, infra-estrutura econômica e social, planejamento e administração, saneamento, que assumiriam frente aos objetivos de dinamização econômica da região.

O grande marco da urbanização montes-clarense é a década de 1980, quando o município atrai vários investimentos no setor produtivo, notadamente no campo industrial. O processo de industrialização, viabilizado por incentivos da Superintendência de Desenvolvimento do Nordeste (SUDENE), alterou a organização espacial de Montes Claros, contribuindo para 0 aumento populacional, a expansão da malha urbana e o surgimento de problemas sócio-ambientais típicos das grandes cidades, como a violência, a falta de infra-estrutura de serviços urbanos, o desemprego, a favelização, a degradação ambiental, entre outros.

Recentemente o setor terciário tem-se destacado como o principal responsável pelo papel regional desse município. O comércio, a expansão de atividades de apoio, transportes, setores financeiros, comunicação, saúde, educação, cultura e diversão despontam como as atividades mais importantes na composição da economia municipal [...]. (PMMC, 1991).

Segundo o diagnóstico do PROECl para o município (FJP, 1983b) considerou como razoável a situação do esgoto sanitário e poucos e localizados, os problemas da drenagem nas áreas mais pobres. A energia elétrica atende $55 \%$ das moradias e $12 \%$ tem energia na porta. 


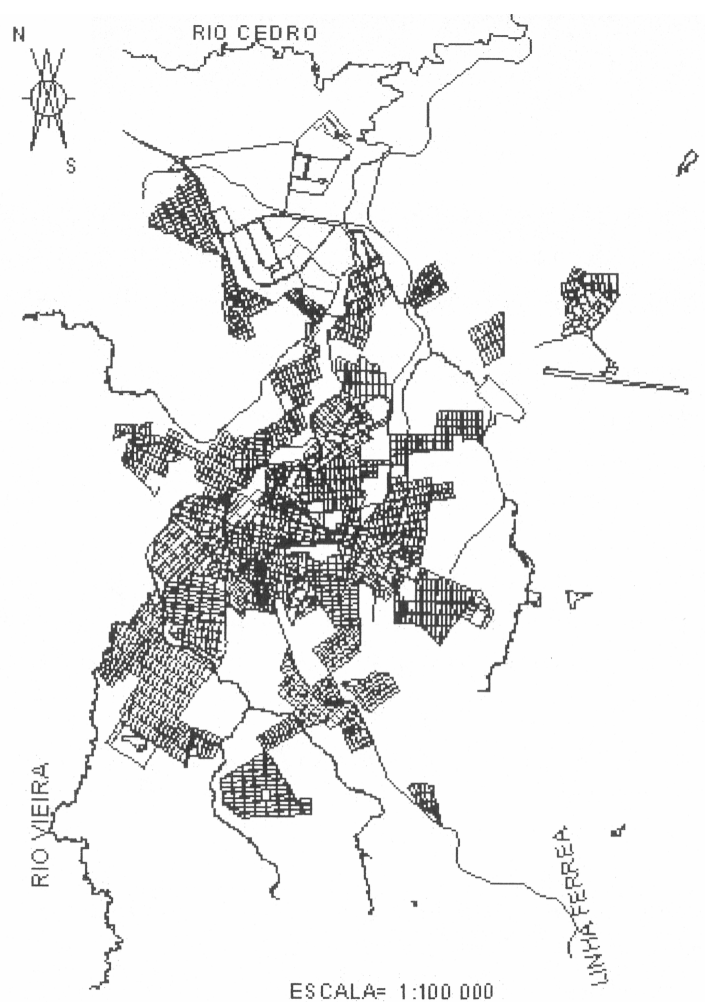

Mapa 16 - Mapa Urbano de Montes Claros/MG, 1970.

FONTE: LEITE; PEREIRA, 2004.

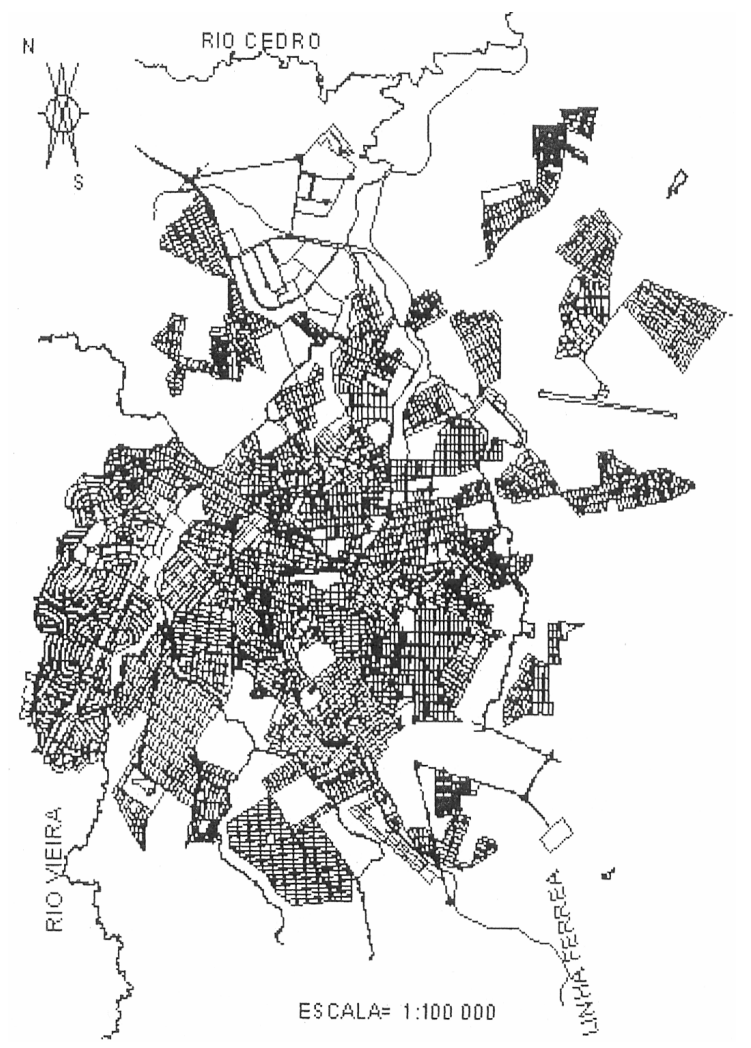

Mapa 17 - Mapa Urbano de Montes Claros/MG, 1980.

FONTE: LEITE; PEREIRA, 2004. 
Comparando a malha urbana do município em 1970 e após os investimentos para industrialização, em 1980, pode ser percebida da grande transformação do espaço urbano de Montes Claros (Mapa 18). Segundo Leite e Pereira (2004), nas décadas seguintes ocorreram aprovação de novos loteamentos, sem implantação dos mesmos, que não ampliaram em proporção significativa a malha de 1980.

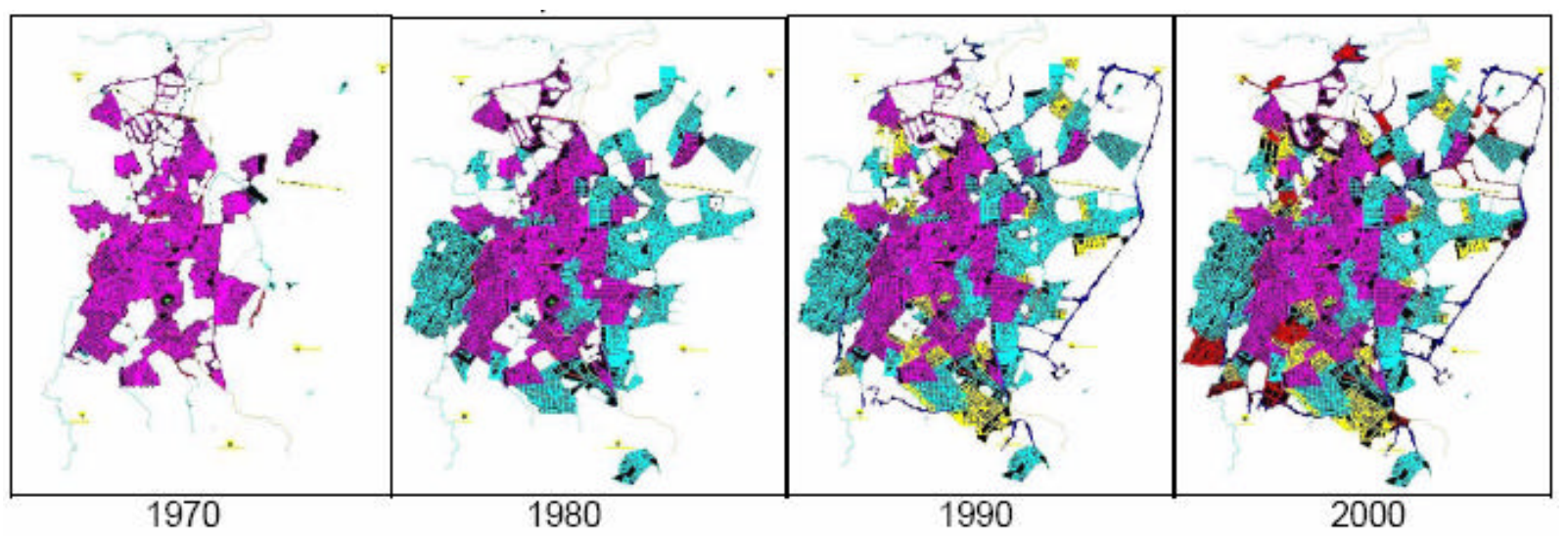

Mapa 18 - Expansão urbana de Montes Claros/MG - 1970-2000.

FONTE: LEITE; PEREIRA, 2004.

A idéia difundida por Leite e Pereira pode ser corroborada por Francisconi e Souza (1976) que afirmam: "acredita-se que é teoricamente consistente admitir a predominância da indústria como principal fator explicativo da urbanização." (FRANCISCONI; SOUZA, 1976, p. 13)

A Matriz de Indicadores de Qualidade de Vida Urbana apresentada a seguir permite que seja vislumbrado o aumento da qualidade de vida. São os seguintes dados que podem nos servir de base para a averiguação da melhoria da qualidade de vida urbana advinda das ações de tais políticas públicas, embora não sejam elas as únicas explicações. 
Quadro 17 - Matriz de Indicadores de Qualidade de Vida Urbana - Montes Claros - Matriz com o total dos indicadores

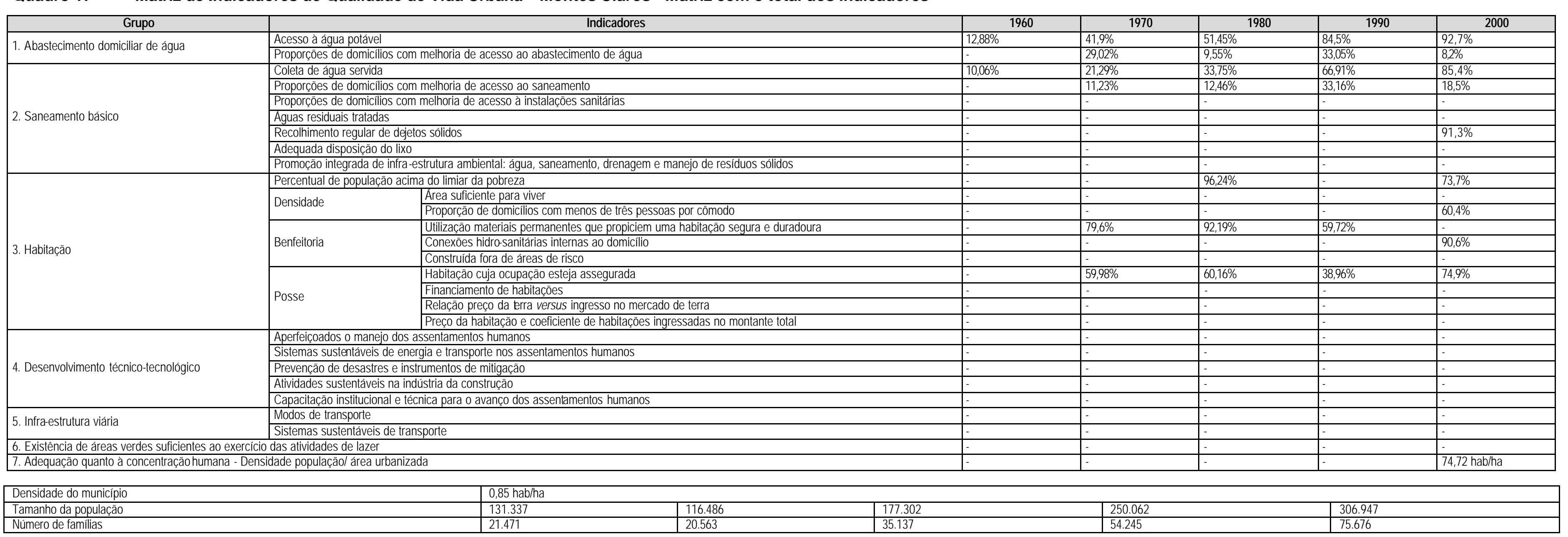

Támanho da populaça

Quadro 18 - Matriz de Indicadores de Qualidade de Vida Urbana - Montes Claros - 1ª Ordenação dos dados

\begin{tabular}{|c|c|c|c|c|c|c|}
\hline Grupo & Indicadores & 1960 & 1970 & 1980 & 1990 & 2000 \\
\hline \multirow{2}{*}{ 1. Abastecimento domiciliar de água } & Acesso à água potável & $12,88 \%$ & $41,9 \%$ & $51,45 \%$ & $84,5 \%$ & $92,7 \%$ \\
\hline & Proporções de domicílios com melhoria de acesso ao abastecimento de água & & $29,02 \%$ & $9,55 \%$ & $33,05 \%$ & $8,17 \%$ \\
\hline \multirow{3}{*}{ 2. Saneamento básico } & Coleta de água servida & $10,06 \%$ & $21,29 \%$ & $33,75 \%$ & $66,91 \%$ & $85,4 \%$ \\
\hline & Proporç̧ôes de domiclilios com melhoria de acesso ao saneamento & & $11,23 \%$ & $12,46 \%$ & $33,16 \%$ & $18,5 \%$ \\
\hline & \begin{tabular}{|l|} 
Recollhimento regular de dejejtos sólidos \\
\end{tabular} & & & & & $91,3 \%$ \\
\hline \multirow{5}{*}{ 3. Habitação } & Percentual de populacãoa acima do limiar da pobreza & - & - & $96,24 \%$ & $1-$ & $73,6 \%$ \\
\hline & \begin{tabular}{|l|l} 
Densidade & Proporção de domiclilios com menos de três pessoas por cômodo \\
\end{tabular} & - & & & & $60,4 \%$ \\
\hline & Utilização materiais permanentes que propiciem uma habitação segura e duradoura & - & $79,6 \%$ & $92,19 \%$ & $59,72 \%$ & \\
\hline & Conexões hidro-sanitárias internas ao domicílio & & & & & $90,6 \%$ \\
\hline & Habitação cuja ocupação esteja assegurada & - & $59,98 \%$ & $60,16 \%$ & $38,96 \%$ & $74,9 \%$ \\
\hline \multirow{2}{*}{\multicolumn{2}{|c|}{$\begin{array}{l}\text { 6. Existência de áreas verdes suficientes ao exercício das atividades de lazer } \\
\text { 7. Adeounacão auanto à concentracão humana - Densidade pooullacãol área urbanizada }\end{array}$}} & & & & & \\
\hline & & & & & & 74,72 hab/ha \\
\hline
\end{tabular}

\begin{tabular}{l} 
6. Existência de âreas verdes sưficientes ao exercició das atividades de lazer \\
\hline 7. Adequação quanto à concentraçăa humana - Densidade populaçãol área urbanizada
\end{tabular}

Quadro 19 - Matriz de Indicadores de Qualidade de Vida Urbana - Montes Claros - Composição tonal

\begin{tabular}{|c|c|c|c|c|c|c|}
\hline Grupo & Indicadores & 1960 & 1970 & 1980 & 1990 & 2000 \\
\hline 1. Abastecimento domiciliar de água & Acesso à água potável & & & & & \\
\hline \multirow{3}{*}{ 2. Saneamento básico } & Coleta de água servida & & & & & \\
\hline & \begin{tabular}{|l|l} 
Recolhimento regular de dejetos sólidos \\
\end{tabular} & & & & & \\
\hline & Percentual de população acima do limiar da pobreza & - & & & & \\
\hline \multirow{4}{*}{ 3. Habitação } & \begin{tabular}{|l|l|} 
Densidade & Proporção de domiclilios com menos de três pessoas por cômodo \\
\end{tabular} & & & & & \\
\hline & \begin{tabular}{|l|l} 
Benfeitoria & Utilizaçã̃o materiais permanentes que propiciem uma habitação segura e duradoura \\
\cline { 2 - 3 }
\end{tabular} & - & & & & \\
\hline & Conexōes hidro-sanitárias internas ao domicilio & & & & & \\
\hline & Habitação cuja ocupação esteja assegurada & & & & & \\
\hline
\end{tabular}


Constata-se que, considerando os indicadores de informação existentes e presentes, a situação ambiental do município, no caso, Montes Claros, tendeu a uma ascensão de qualidade, haja vista a análise da última coluna da matriz, que para o ano de 2000 , que apresenta uma apreciação de valoração superior a $50 \%$.

Na categoria 1 - 'Abastecimento domiciliar de água', pode-se dizer que a melhoria efetiva ocorre exatamente no período de incidência das políticas públicas e seus investimentos. Dos anos de 1970 para os anos de 1990, o aumento de famílias abastecidas por água da rede geral de abastecimentos é de $42,6 \%$, enquanto 0 crescimento do número de famílias aumenta 2,6 vezes. Em 1990, chega-se a um atendimento de quase $84,5 \%$ da população. A coleta de água servida, apresentada pela categoria 2 - 'Saneamento básico', também tem significativa melhora no mesmo período, passando a abranger cerca de $66,9 \%$ das famílias na década de 1990 , tendo começado com um horizonte de $22,291 \%$ das famílias nos anos de 1970 . No período compreendido entre os anos 1970 e 1990, foi quando da maior proporção de domicílios com melhoria de acesso ao saneamento para este caso, sendo de cerca de $45,7 \%$.

Os dados para o ano de 2000 revelam que a qualidade ambiental para os parâmetros abordados até aqui apresenta-se de 'média a adequada', pois ambos, abastecimento de água e coleta de esgoto apresentam valores relativos superiores a $75 \%$, conforme estabelecido na metodologia deste trabalho.

Devidamente considerado deve ser o fato da inexistência de uma série histórica de informações para o dado de recolhimento regular de dejetos sólidos. Este dado só está presente para 2000, apresentando 91,3\% das famílias.

Para a categoria 3 - 'Habitação', alguns dados estão presentes, sendo aqui elucidados. O percentual de população acima do limiar da pobreza está presente para os anos de 1980 e 2000, havendo uma diminuição relativa nesses 20 anos. Em 
1980, eram 96,2\% da população para 73,7\% em 2000. Estes números possivelmente apontam para o caráter do empobrecimento geral da população do município e do país.

Os números de habitações cuja benfeitoria foi feita utilizando 'materiais permanentes que propiciem uma habitação segura e duradoura' apontam para a atuação das políticas urbana, neste caso provavelmente provenientes da existência do $\mathrm{BNH}$, que teve suas atividades encerradas nos anos 80 , período com maior número de famílias com acesso ao tipo de benfeitoria colocado, ou seja, 92,2\%. No período anterior a 1980 , o percentual encontrado era de $79,6 \%$ e no posterior, $59,7 \%$.

A posse talvez reflita alguma articulação também com a existência da atuação do BNH. No período de 1970 a 1990, localiza-se nos anos 1980 o melhor desempenho do indicador 'Habitação cuja posse esteja assegurada', antes do período de 2000. Em 1980 o valor era de 60,2\% e em 2000, 74,9\%.

No indicador da categoria 7 - 'Adequação quanto à concentração humana densidade de população em área urbanizada', tem-se 74,72 hab/ha, uma densidade considerada adequada para ocupação humana de clima tropical. Considerando-se a área total do município $3.582,0 \mathrm{~km}^{2}$ e sua população de 306.947 habitantes, tem-se a densidade de 1,052 hab/ha para o município como um todo. Em relação ao estabelecido por Dias (2002), a área disponível por habitante no planeta é hoje um hectare para cada habitante. O município encontra-se dentro da estabelecido.

A Matriz de Qualidade de Ambiente Urbano - Composição Tonal permite que seja percebida a totalidade das informações, apenas qualitativamente. Percebe-se do lado direito do quadro a melhora da qualidade ambiental, sendo que toda a última coluna, referente ao ano de 2000, apresenta dados mais adequados à constituição de um ambiente urbano sustentável, conforme parâmetros necessários aqui 
estipulados para a composição da matriz. A leitura que pode ser feita é a de que a situação ambiental tendeu a uma melhora.

Considerando que foi possível obter apenas 21 dados dos 140 que foram propostos para a matriz total, tem-se uma estatística que não chega a ser determinante da sustentabilidade do ambiente da cidade, pois 21 dados obtidos correspondem a 15\% do total considerado necessário para análise do município.

Para o caso de Montes Claros, 15 dos dados estão classificados como estando entre as classes 'média' e 'adequada qualidade' do ambiente urbano, o que equivale a $10,7 \%$ do total, e dentre estes 15 , apenas oito, $5,7 \%$ dos elementos levantados estão classificados como 'adequada' qualidade do ambiente urbano.

Considerando o universo total como sendo o dos 21 dados obtidos, a sustentabilidade pode ser mais facilmente aceita. Sendo 15 o número de dados entre as classes 'média' e 'adequada qualidade' do ambiente urbano, tem-se 71,4\% e quanto aos oito dos elementos classificados como 'adequada qualidade' do ambiente urbano, tem-se $38,1 \%$ dos dados.

Tendo como referencial apenas os dados obtidos, o ambiente poderia ser considerado com tendendo à adequação. Como no entanto, o universo de dados sem resposta é muito grande - o que significa uma provável negligência em relação ao seu comportamento - a qualidade estaria comprometida.

Considerando também algumas informações sobre indicadores apresentadas pelo IDH-Municipal (PNUD; IPEA; FJP, 2003):

No período 1991-200o, o índice de Desenvolvimento Municipal (IDHM) de Montes Claros cresceu 8,60\% passando de 0,721 em 1991 para 0,783 em 2000.

A dimensão que mais contribuiu para este crescimento foi a Educação, seguida pela Renda e pela Longevidade (...).

Se mantivesse esta taxa de crescimento do IDH, o município levaria 16,8 anos para alcançar São Caetano do Sul (SP), o município como o melhor IDH do Brasil $(0,919)$ e 7,5 anos para alcançar Poços de Caldas (MG), o município com o melhor IDH do Estado $(0,841)$. 
Segundo a classificação do PNUD, o município está entre as regiões consideradas de médio desenvolvimento humano (IDH entre 0,5 e 0,8) (PNUD; IPEA; FJP, 2003).

O índice de Gini de Montes Claros demonstra um aumento na concentração de renda, sendo 0,61 em 1991 e passando a 0,62 em 2000. A classificação exposta acima, de 'regiões consideradas de médio desenvolvimento humano' corrobora com a análise ambiental anteriormente descrita. A renda per capta média do município cresceu $45,74 \%$, passando de $\$ \$ 168,40$, em 1991, para $\$ 245,43$, em 2000 . A pobreza (medida pela proporção de pessoas com renda domiciliar per capta inferior a $R \$ 75,50$, equivalente à metade do salário mínimo vigente em agosto de 2000) diminuiu 28,30\%, passando de 48,2\%, em 1991, para 34,5\%, em 2000 .
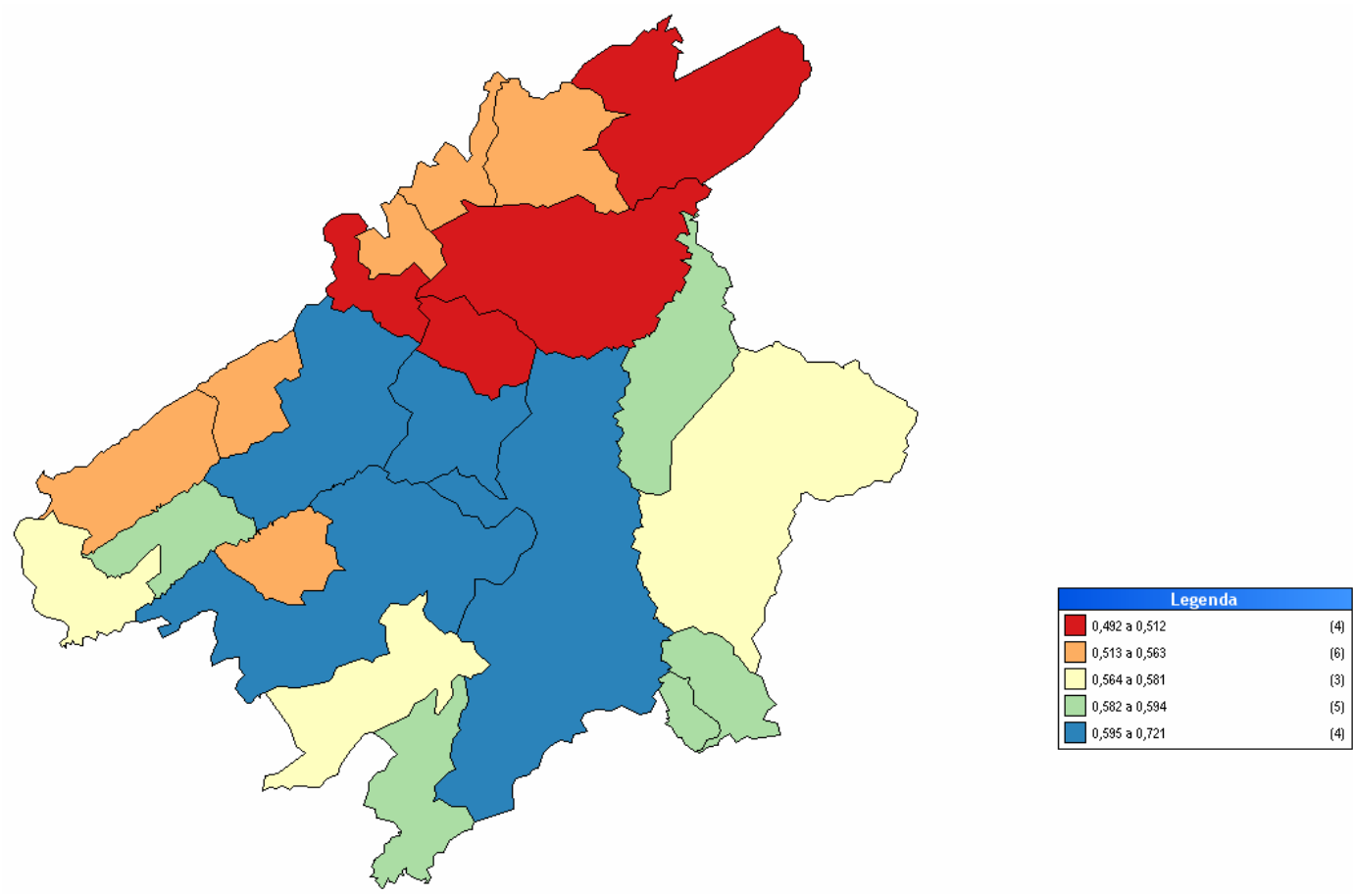

Mapa 19 - I Índice de desenvolvimento humano dos municípios da microrregião de Montes Claros/MG, 1991.

FONTE: PNUD; IPEA; FJP, 2003. 

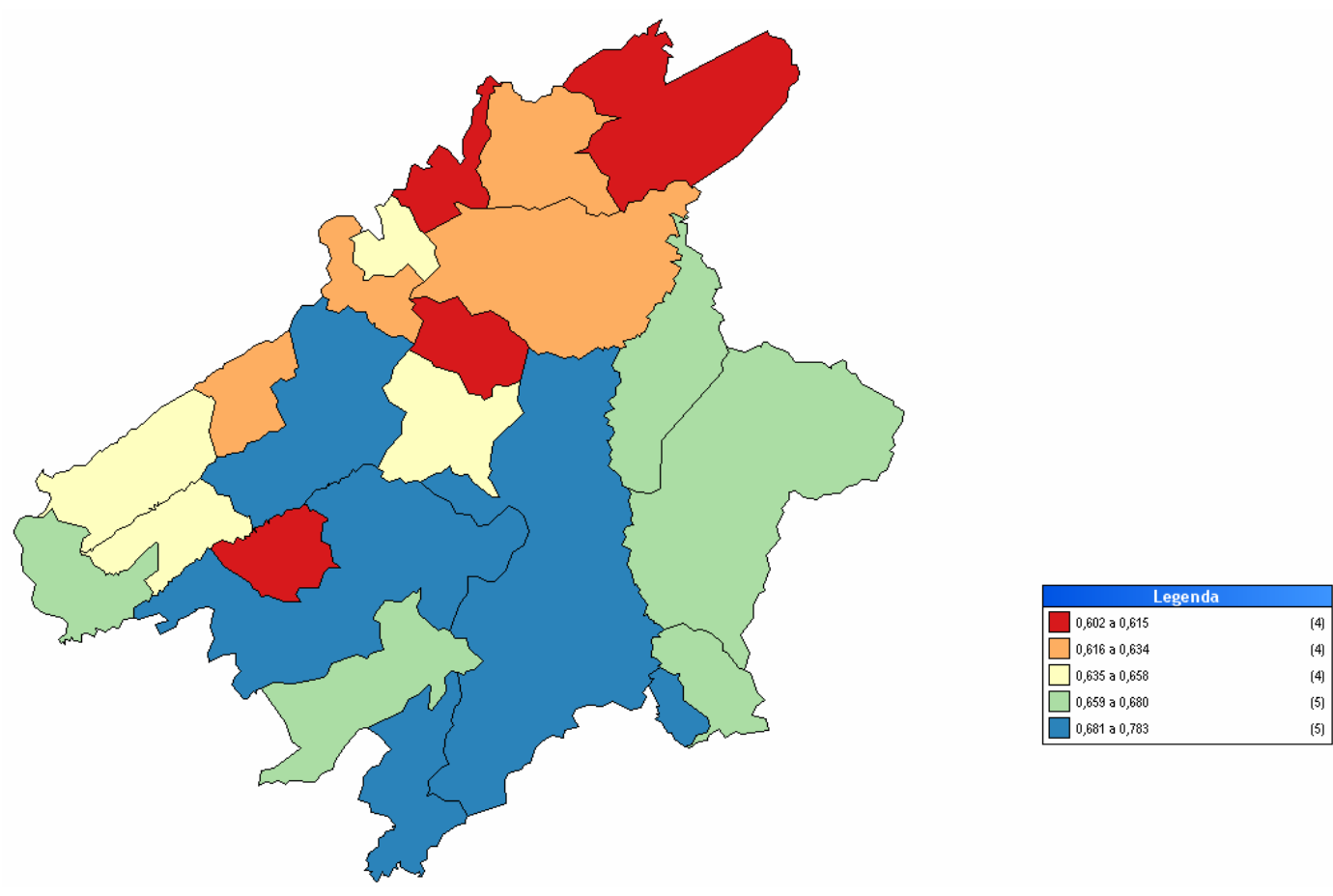
Mapa 20 - $\quad$ Índice de desenvolvimento humano dos municípios da microrregião
de Montes Claros/MG, 2000.

FONTE: PNUD; IPEA; FJP, 2003.

Os mapas 19 e 20 permitem ver a modificação dos índices de IDH-Municipal na Microrregião entre os anos de 1991 e 2000, tendo o município de Montes Claros ao meio, em cor azul. 


\subsection{POÇOS DE CALDAS}

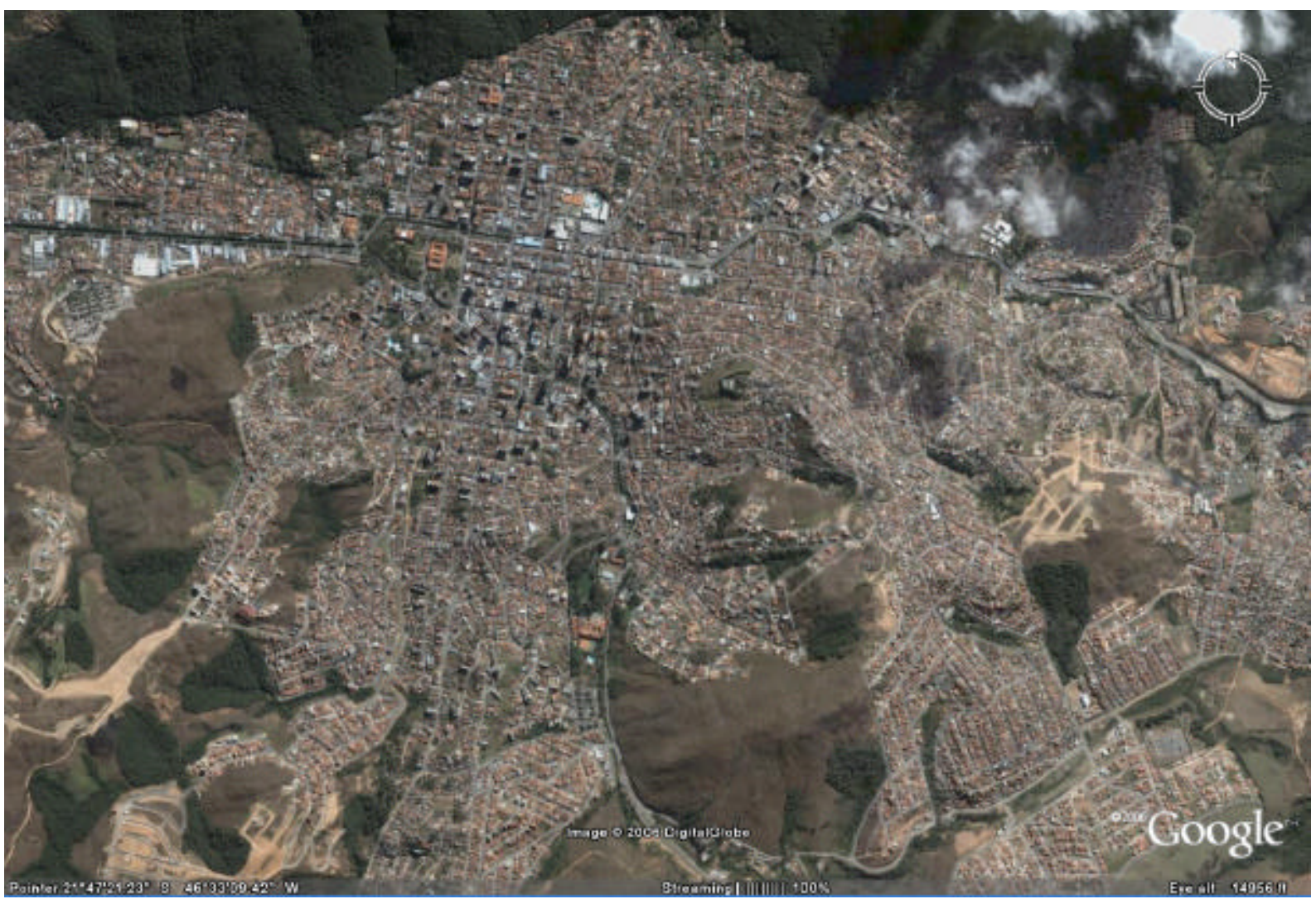

Figura 4 - $\quad$ Vista aérea de Poços de Caldas/MG (altitude 4,55 km).

FONTE: Google Earth, Digital Globe. Image @, 2006.

Poços de Caldas tem seu surgimento em 1822 e, até as três primeiras décadas do século vinte, vem se desenvolvendo principalmente em decorrência da presença de recursos hidrominerais em seu território.

A foto ilustra a cidade recortada por uma via, na parte superior. Esta via é a canalização do Ribeirão Caldas, que é a principal drenagem da cidade, recebendo as demais bacias e córregos. De Belo Horizonte ou do Rio, chega-se a Poços por esta via, vindo da direita e atravessando o município, vai-se para São Paulo, à esquerda.

Com a expansão da indústria ligada à pecuária local e com a decadência da cafeicultura na região no decorrer dos anos de 1930, a mancha urbana espalha-se 
ao longo do Ribeirão Caldas e do Ribeirão do Serra, numa amplitude maior do que o

dobro da urbanização até então existente.

Sendo uma cidade de forte apelo turístico, Poços de Caldas $^{37}$ teve a

implementação desta atividade vinculada aos avanços ocorridos no aperfeiçoamento

da infra-estrutura hoteleira das termas e cassinos, além da presença efetiva do

Governo do estado. Entretanto, na década de 1940, ocorre uma fase de estagnação

causada pela proibição do jogo no país e conseqüente fechamento dos cassinos.

Esta fase da economia será gradativamente superada com a implantação de

empresas industriais a partir dos anos de 1960, prioritariamente atuando na

37 A região onde se localiza o atual Município de Poços de Caldas foi inicialmente habitada pelos Cataguases que, em 1675, ofereceram combate e venceram a célebre bandeira de Lourenço Castanho, cognominado "O Velho". Somente em meados do século XVIII verificou-se o seu desbravamento propriamente dito. Os desbravadores penetraram o Planalto, abrindo vias de comunicação para as novas "descobertas" ou socavões, em pesquisas infrutíferas, através dos braços do rio Pardo. Três fatores influíram no desenvolvimento social e econômico deste período: a busca de ouro, a abertura de estradas - que facilitassem a fiscalização e dificultassem os contrabandos - e ainda a procura de "água santa", para fins medicinais. Como até meados do século XVIII a "única coisa que dava valor aos territórios novos, motivando sua ocupação e povoamento, era a descoberta de ouro", a região só foi ocupada e povoada quando terminada a era da mineração e iniciado o "ciclo pastbril'. Com a busca do capim indispensável à pecuária valorizou-se a região dos "Campos de Caldas", como passou a ser chamado o local. O "ouro verde", de que é particularmente rica, facilitou a instalação do núcleo pastoril que, economicamente, substituiu a lavra e grupiara. Dos primeiros moradores de Caldas, 20\% saíram de Santana do Sapucaí, 12\% de Lavras do Funil, 11\% de Cabo Verde. Entre os que vieram para os "Campos de Caldas", nos últimos anos de 1700, encontrava-se o Padre Manoel Gonçalves Correia, que instalou uma fazenda no "Monte Alegre", junto à fronteira paulista. Lá ergueu uma ermida, a primeira igreja da região, dedicada a Nossa Senhora do Carmo. Os povoadores foram aumentando e com sua propulsão, promovendo o recuo da divisa; se no "ciclo do ouro" era o descobrimento das novas minas que trazia a massa invasora, no "ciclo pastoril" a corrida pelas zonas das "campinas" fez com que o fenômeno se repetisse. Em 1700, nas suas últimas décadas, toda a zona de Caldas era completamente despovoada. A região deserta entre as duas Capitanias estava, pois, limitada por duas estradas paralelas - a Estrada de Goiás, pelo lado paulista, e, pelo lado mineiro, as "antigas picadas reabertas por Luís Diogo, passando por Cabo Verde, Campestre e Ouro Fino". Foi em 1776 ou 77, que o guarda-mor Veríssimo João de Carvalho, anotado pelo "Cabo do Registro de Ouro Fino", fez a "tranqueira" que lhe tomou o nome. Ordenou-lhe a feitura o Governador da capitania de Minas Gerais, "para divisão entre as duas capitanias" e mandou que daquela tranqueira para dentro não se adiantasse "uma só polegada aos súditos de Minas, e nem se consentisse que por parte da Capitania de São Paulo se entrasse para a de Minas um só palmo". A tranqueira era "hum fexo", de troncos derrubados, situado ali em "humas vertentes das cabeceiras do Rio Pardo". Os paulistas, na "marcha para o Oeste" em demanda de pastagens, pulavam as tranqueiras e arrancavam os moirões de posse como tinham feito no "ciclo do ouro" e assim iam invadindo 0 Planalto. O recuo da divisa foi o curioso fenômeno que ligou geograficamente a Região do "planalto da Pedra Branca", também chamada "maciço de Poços de Caldas", ao desenvolvimento social e econômico da Capitania de Minas. Começou com a expulsão do paulista Barrotemos Buenos do distrito de Campanha, em 1743, e terminou com a disputa entre a Câmara de Caldas e a de São João da Boa Vista, na Fazenda do óleo (atual município de Andradas), por ocasião do inventario de Antônio Martiniano de Oliveira, em 1874. Quando das costumeiras penetrações realizadas pelos aventureiros da época, foram descobertos, em meio do planalto, os poços de água quente, cujo valor medicinal foi de pronto constatado. Nasceu desse fato o constante crescimento do lugarejo que imediatamente se formou nas vizinhanças dos poços. 0 patrimônio do embrionário núcleo formou-se com a doação de 40 alqueires de terras, pelo major Joaquim Bernardes da Costa Junqueira, juntamente com seus filhos e genros, em 6 de novembro de 1872. Esta data é considerada a de fundação da cidade de Poços de Caldas. 0 nome de Caldas veio da tradição portuguesa relacionada com as águas de igual nome existentes em Portugal. Inicialmente era a freguesia de Nossa Senhora da Saúde das Águas de Caldas. (IBGE, 1983). 
exploração de riquezas minerais existentes em profusão em seu subsolo. A cidade consolida-se como pólo regional de comércio e serviço, caracterizado pelo acentuado fluxo migratório, especialmente representado por população de baixo poder aquisitivo.

Sem um instrumento eficaz de controle e ordenamento territorial, acentuour se a ocupação desordenada das áreas de alta declividade e a implantação de malhas viárias totalmente desarticuladas, muitas vezes, impostas pela própria condição topográfica das áreas parceladas. (PREFEITURA..., 1992, p. 237).

Como em grande parte dos municípios brasileiros, não ocorreu a efetiva ocupação das áreas urbanas disponibilizadas através dos loteamentos, ficando a cidade com uma densidade rarefeita em alguns pontos, como pode ser visto na foto da página anterior, pela descontinuidade permitida pelas características físicas de seu sítio. Nos anos compreendidos entre 1950 e 1960, um novo surto de industrias de pequeno porte propiciou novo aumento do número de parcelamentos de solo para obtenção de lotes, já com lotes de dimensão mais reduzida. O fenômeno migratório da região tornou-se acentuado e Poços de Caldas, o centro da microregião.

\section{Tabela 9 - Microrregião de Poços de Caldas/MG.}

Macrorregião Sul de Minas

Microrregião: Poços de Caldas

Municípios: $\quad$ Albertina, Andradas, Bandeira do Sul, Botelhos, Caldas, Campestre, Ibitiúra de Minas, Inconfidentes, Jacutinga, Monte Sião, Ouro Fino, Poços de Caldas, Santa Rita de Caldas FONTE: ALMG, 2006.

A expansão urbana levou a um aumento da arrecadação municipal que não foi correspondente à necessidade criada pela extensão dos arruamentos existentes, o que fez com que os serviços urbanos estivessem sempre em número insuficiente para atender à demanda. 
Sendo a topografia da cidade acentuada, a ocupação de morros passou a ocorrer nas mesmas características ou com piores, do que o restante da infraestrutura da cidade: descontinuidade da malha urbana, ocupação de encostas com declividades acentuadas, abertura de loteamentos em áreas de difícil implantação de infra-estrutura. (FAUUSP, 1984).

No período 1970/80, no qual ocorre novo incremento populacional significativo, a cidade funciona como um importante centro sub-regional ligado a Campinas. A área central começou a viver o processo de renovação urbana, sendo o uso residencial substituído pelos comerciais e de serviço.

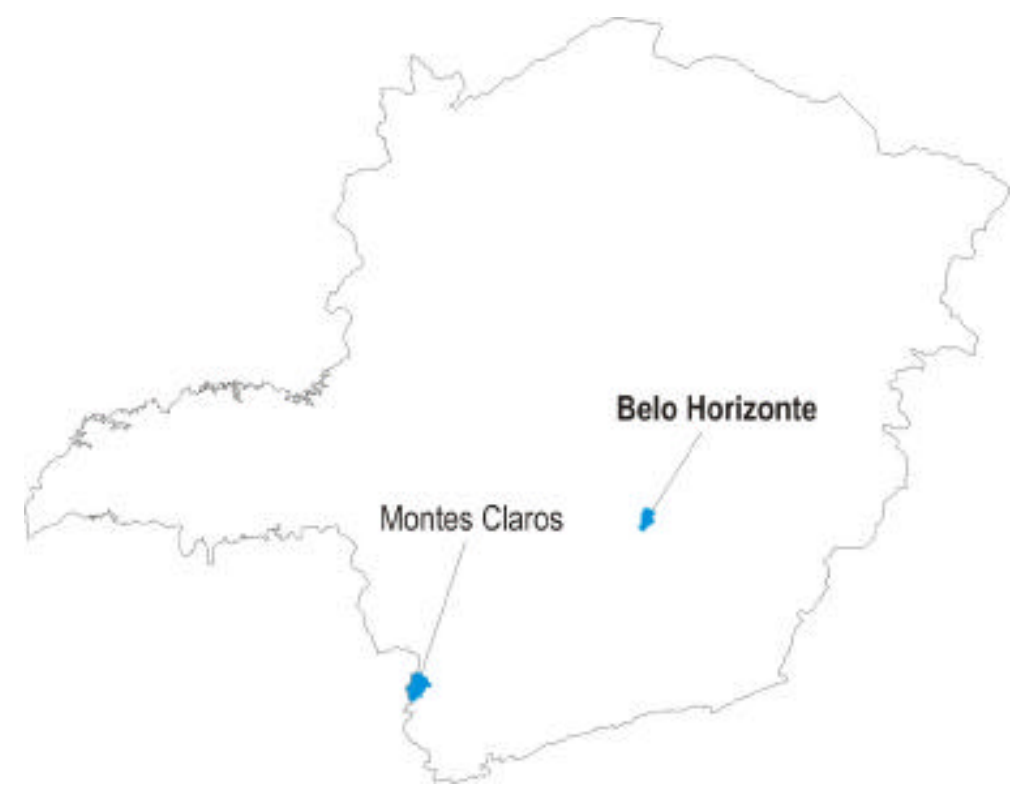

\section{Mapa 21 - Situação de Poços de Caldas/MG no Estado.}

FONTE: IGA, 1999.

A expansão urbana e a atividade minerária foram e são responsáveis por um grande aumento do passivo ambiental do município, seja pela supressão de áreas verdes, seja pela ocupação de áreas importantes para a conservação ambiental.

No PNCCPM, Poços de Caldas participou de dois convênios. No primeiro deles, o município recebeu $\operatorname{Cr} \$ 60,618$ milhões, sendo $\operatorname{Cr} \$ 11,808$ milhões contrapartida do município, $\operatorname{Cr} \$ 35,142$ milhões do Estado de Minas Gerais e 
Cr\$13,667 da União. Destes últimos, quase a totalidade foi aplicada em obras de saneamento e cerca de Cr\$ 3,66 milhões, em planejamento e administração.

No segundo convênio teve o valor de $\mathrm{R} \$ 205,3$ milhões, sendo que a União forneceu $\mathrm{R} \$ 107,5$ milhões e o restante foi dividido entre estado e município. A maior parcela foi aplicada na canalização do córrego Monjolinho e na elaboração de projeto executivo para estação de tratamento de esgoto.

Tabela 10 - Investimentos urbanos em Poços de Caldas/MG. Recursos em Cr\$1.000,00 - 1980.

\begin{tabular}{|c|c|c|c|c|c|c|c|}
\hline \multirow{2}{*}{\multicolumn{2}{|c|}{ Projetos }} & \multirow{2}{*}{$\begin{array}{l}\text { Unidade } \\
\text { executora }\end{array}$} & \multirow[b]{2}{*}{ Município } & \multirow[b]{2}{*}{ Estado } & \multicolumn{2}{|c|}{ União } & \multirow[b]{2}{*}{ Total } \\
\hline & & & & & $\begin{array}{l}\text { FNDUI } \\
\text { OP }\end{array}$ & Outros & \\
\hline \multirow[t]{3}{*}{$1-$} & Planejamento e Administração & & 1.000 & $1.908,1$ & $3.667,5$ & & $6.575,6$ \\
\hline & $\begin{array}{l}\text { 1. Reforço de Capacidade de } \\
\text { Planejamento da Prefeitura }\end{array}$ & $\begin{array}{l}\text { Prefeitura } \\
\text { Municipal }\end{array}$ & & 658,1 & $1.417,5$ & & $2.075,6$ \\
\hline & $\begin{array}{l}\text { 2. Elaboração da Planta Urbana } \\
\text { Básica de Cidade }\end{array}$ & $\begin{array}{l}\text { Prefeitura } \\
\text { Municipal } \\
\end{array}$ & 1.000 & 1.250 & 2.250 & & 4.500 \\
\hline \multirow[t]{2}{*}{ II - } & Saneamento & & $10.808,6$ & $33.234,4$ & 10.000 & & 54.043 \\
\hline & $\begin{array}{l}\text { 1. Execução de Interceptores, } \\
\text { Emissários de Tratamento de Esgoto } \\
\text { ao Longo do Ribeirão Caldas }\end{array}$ & $\begin{array}{l}\text { Prefeitura } \\
\text { Municipal }\end{array}$ & $10.808,6$ & $33.234,4$ & 10.000 & & 54.043 \\
\hline \multicolumn{2}{|c|}{ TOTAL } & & $11.808,6$ & $35.142,5$ & $13.667,5$ & & $60.618,6$ \\
\hline
\end{tabular}

FONTE: Convênio 70/80 do Programa de Apoio às Capitais e Cidades de Porte Médio, Estado de Minas Gerais.

O PROECl, em seu diagnóstico sobre o município de Poços de Caldas, evidenciou as seguintes características:

- potencialidade econômica, que assegure retorno de investimentos e retenção de fluxos demográficos;

- possibilidade de diminuição da pobreza urbana;

- potencialidade de integração espacial micro e macrorregional;

- aumento da oferta de empregos e renda visando um desenvolvimento mais equilibrado da economia;

- abastecimento de setores da economia e da população com bens e serviços, inclusive infra-estrutura;

- diminuição das emigrações para fora da região (FJP, 1980c).

O documento cita a existência de um Plano de Desenvolvimento para o Sul de Minas, que possuía as mesmas premissas básicas do PROECl e para tal, trabalhariam em ajustamento: 
- aumento da oferta de emprego e renda visando a um desenvolvimento mais equilibrado da economia;

- abastecimento dos setores da economia e da população de bens e serviços, inclusive infra-estrutura;

- diminuição das emigrações para fora da região. (FJP, 1980c).

O Plano de Desenvolvimento para o Sul de Minas colocava também a necessidade de formulação de uma organização espacial onde eixos de desenvolvimento unissem centros intermediários para definir direções de desenvolvimento e integrar os diversos centros.

Tabela 11 - Investimentos urbanos em Poços de Caldas/MG. Recursos em Cr\$1.000,00 - 1982.

\begin{tabular}{ll|l|r|r|r|r}
\hline \multicolumn{1}{c|}{ Projetos } & Unidade executora & \multicolumn{1}{c|}{ Município } & \multicolumn{1}{c|}{ Estado } & \multicolumn{1}{c|}{ União } & \multicolumn{1}{c}{ Total } \\
\hline I- $\quad$ Planejamento e Administração & & 3.688 & & 14.750 & 18.438 \\
\hline 1. Reforço institucional as Prefeituras & Prefeitura e FJP & 3.688 & & 14.750 & 18.438 \\
\hline II - $\quad$ Infra-estrutura Social & & & 12.683 & & 12.683 \\
\hline$\quad$ 1. Construção de dois centros de saúde & SES/MG & & 12.683 & & 12.683 \\
\hline III - Infra-estrutura econômica & & & 43.520 & & 43.520 \\
\hline 1. Crédito às microempresas & BDMG & & 43.520 & & 43.520 \\
\hline IV - Saneamento & & 37.859 & & 92.811 & 130.670 \\
\hline $\begin{array}{l}\text { 1. Elaboração do Projeto Executivo da } \\
\text { Estação de Tratamento de Esgoto }\end{array}$ & FJP & 884 & & 3.537 & 4.421 \\
\hline 2. Canalização do Córrego Monjolinho & Prefeitura & 36.975 & & 89.274 & 126.249 \\
\hline TOTAL & & 41.547 & 56.203 & 107.274 & 205.311 \\
\hline
\end{tabular}

FONTE: Convênio 185/SG/82 do Programa Estadual de Centros Intermediários, Minas Gerais.

Uma das atividades tradicionais mais relevantes da cidade, o turismo associado a utilização dos recursos hidrominerais entrava em choque direto com a exploração industrial, tendo que ser dissipadas as incompatibilidades pela intervenção da municipalidade.

A modernização da agricultura resultou na dispensa da mão-de-obra que enfatizava o quadro de perda populacional da micro-região. Esta modernização estava amplamente associada à ampliação do cinturão verde de abastecimento para a cidade de São Paulo e outros centros paulistas. Além desta perda pela introdução de técnicas que demandam menos contingente de trabalhadores e que acabam por alijar o pequeno produtor do processo produtivo, a presença da reintensificação cafeicultura também associada às questões de emprego, devido à demanda sazonal 
de mão de obra que possui a atividade. Além disso, as vicissitudes climáticas da geada e da instabilidade do mercado internacional faziam com que o emprego sofresse grande variação.

Assim sendo, a cidade possuía a necessidade de potencializar esta mão de obra liberada, capacitá-la, abordar a diversificação da produção, não permitindo que se baseassem apenas no mercado instável - em ocupação de empregos e de valor de mercado - do café, a necessidade de geração de infra-estrutura para receber as novas instalações fabris sem prejudicar o ambiente da cidade e dotando-o de condições produtivas mínimas. Neste sentido foram apresentados os programas para o município.

A indústria é o fator de maior importância não só no município quanto na microrregião, sendo a mesma a mais importante do sul de Minas. Foi durante a década de 1970 o grande incremento da indústria na cidade, devido ao próprio desenvolvimento do país ocorrido em decorrência do Milagre Econômico - 19681973 mas principalmente pelo desenvolvimento do projeto de industrialização do Sul de Minas. O crescimento industrial do município foi bastante significativo, tendo obtido o setor secundário um aumento de $548,7 \%$ do valor da produção, enquanto o estado possui um aumento de $212,8 \%$.

No fim dos anos 70, o parque industrial apresentava-se consolidado e atraia migrantes de diversas regiões do estado de Minas e do país, atraídos pelo seu crescimento industrial acelerado. Os anos 80 , o investimento no setor secundário perdeu forças, fato ocorrido em todo o país e em grande parte da América Latina.

Assim como a conjuntura nacional contribuiu para o desenvolvimento industrial na década de 70 , essa conjuntura passa, na década seguinte, a ser o seu principal entrave. De 1981 a 84, o Brasil, assim como a América Latina, passou pela maior recessão de sua história. Esta recessão resultou do endividamento externo dos anos 70, quando a partir de 79, os credores do Brasil passaram a cobrar o pagamento da dívida, pressionados em nível externo pelo segundo 
choque do petróleo, pelo aumento da taxa de juros internacional e pela recessão americana em 79-82. (PREFEITURA..., 1992, p. 68).

Este é o quadro do desenvolvimento econômico do município quando da execução dos estudos para elaboração do Plano Diretor em 1992.

Deve ser ressaltado também que o $\mathrm{PROECI}$ não destinou recursos para o município.

Constata-se que, considerando os indicadores de informação existentes e presentes, a situação ambiental do município, no caso, Poços de Caldas, tendeu a uma ascensão de qualidade, haja vista a análise da última coluna da matriz, que para o ano de 2000, que apresenta uma apreciação de valoração prioritariamente superior a $50 \%$.

Na categoria 1 - 'Abastecimento domiciliar de água', pode-se dizer que ocorreu melhoria no período de incidência das políticas públicas e seus investimentos, porém com muito menor destaque do que nos municípios anteriormente analisados, com exceção de Juiz de Fora. Dos anos de 1970 para os anos de 1990, o aumento de famílias abastecidas por água da rede geral de abastecimentos é de $20,7 \%$, enquanto o crescimento do número de famílias aumenta 2,3 vezes. Em 1990, chega-se a um atendimento de 87,1\% da população. Existem problemas de abastecimento de água em áreas mais altas do município. A coleta de água servida, apresentada pela categoria 2 - 'Saneamento básico', também tem significativa melhora no mesmo período, passando a abranger cerca de $88,0 \%$ sendo seu horizonte inicial o atendimento de $51,6 \%$ das famílias nos anos de 1970. No período compreendido entre os anos 1970 e 1990, foi quando da maior proporção de domicílios com melhoria de acesso ao saneamento para este caso, sendo de cerca de $36,4 \%$. No entanto, cabe ressaltar que o tratamento do esgoto coletado, atende apenas a uma pequena parcela da cidade e de maneira precária. 
Quadro 20 - Matriz de Indicadores de Qualidade de Vida Urbana - Poços de Caldas - Matriz com o total dos indicadores

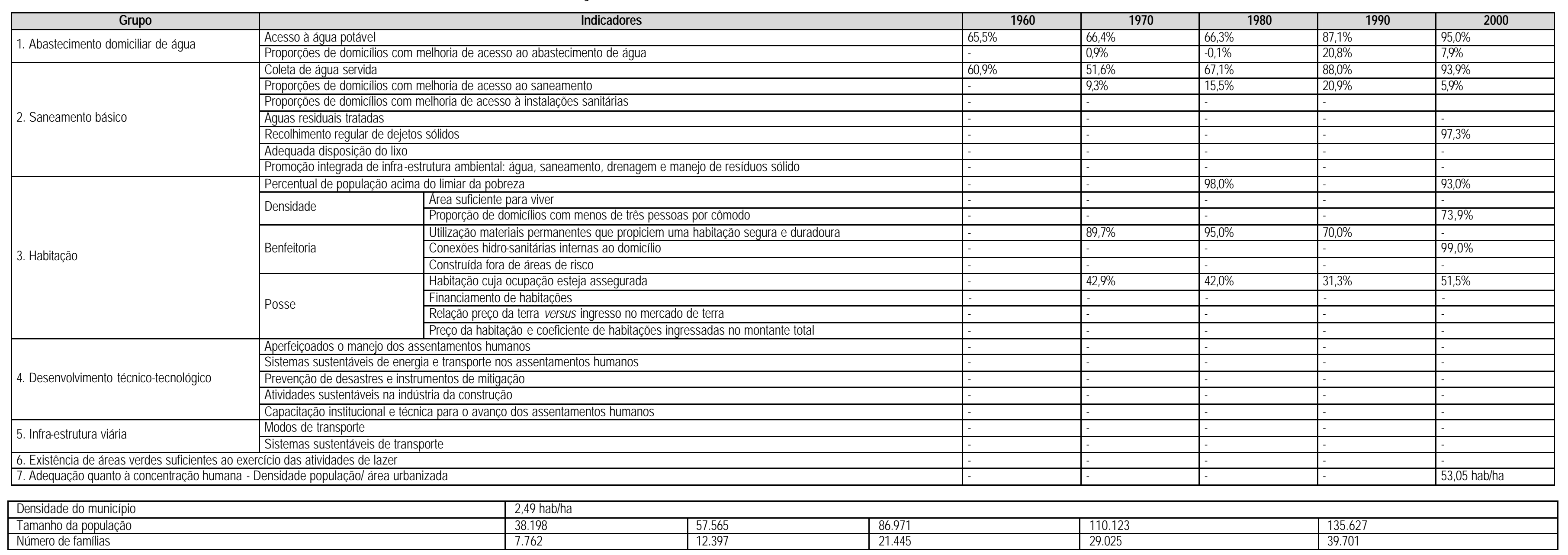

\section{Quadro 21 - Matriz de Indicadores de Qualidade de Vida Urbana - Poços de Caldas - 1ª ordenação dos dados}

\begin{tabular}{|c|c|c|c|c|c|c|}
\hline Grupo & Indicadores & 1960 & 1970 & 1980 & 1990 & 2000 \\
\hline \multirow{3}{*}{ 2. Saneamento básico } & Acesso à água potável & $65,5 \%$ & $66,4 \%$ & $66,3 \%$ & $87,1 \%$ & $95,0 \%$ \\
\hline & \multirow{2}{*}{\begin{tabular}{|l} 
Coleta de água servida \\
Recolhimento regular de dejetos sólidos \\
\end{tabular}} & $60,9 \%$ & $51,6 \%$ & $67,1 \%$ & $88,0 \%$ & $93,9 \%$ \\
\hline & & & & & & $97,31 \%$ \\
\hline \multirow[b]{6}{*}{7 Ado } & Percentual de população acima do limiar da pobreza & - & - & $98,0 \%$ & $F$ & $93,0 \%$ \\
\hline & \begin{tabular}{|l|l} 
Densidade & Proporção de domiclilios com menos de três pessoas por cômodo
\end{tabular} & $-5^{-}$ & & & & $73,9 \%$ \\
\hline & \begin{tabular}{|l} 
Utilizaçãoo materiais permanentes que propiciem uma habitação segura e duradoura \\
\end{tabular} & I- & $89,7 \%$ & $95,0 \%$ & $70,0 \%$ & \\
\hline & Conexões hidro-sanitárias internas ao domicílio & - & & & & $99,0 \%$ \\
\hline & \begin{tabular}{|l|l|} 
Posse & Habitação cuja ocupação esteja assegurada \\
\end{tabular} & - & $42,9 \%$ & $42,0 \%$ & $31,3 \%$ & $51,5 \%$ \\
\hline & Densidade populaçãol área urbanizada & - & & & & 53,05 hab/ha \\
\hline
\end{tabular}

\section{Quadro 22 - Matriz de Indicadores de Qualidade de Vida Urbana - Poços de Caldas - Composição tonal}

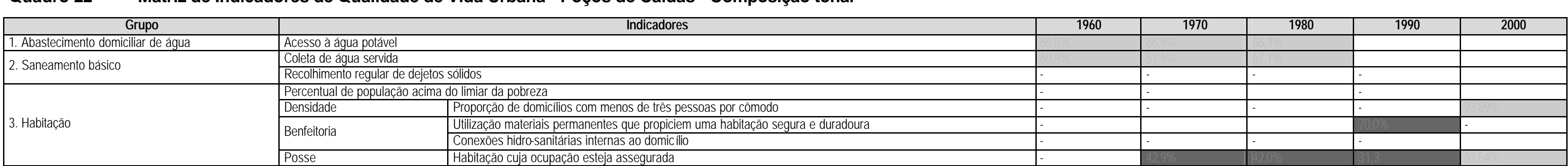


Os dados para o ano de 2000 revelam uma adequada qualidade ambiental para os parâmetros adotados por este trabalho, pois ambos, abastecimento de água e coleta de esgoto apresentam valores relativos superiores a $75 \%$, conforme estabelecido na metodologia deste trabalho.

Devidamente considerado deve ser o fato da inexistência de uma série histórica de informações para o dado de recolhimento regular de dejetos sólidos. Este dado só está presente para 2000, apresentando $97,3 \%$ das famílias. O lixo é coletado e destinado a céu aberto, sem aterro sanitário.

Para a categoria 3 - 'Habitação', alguns dados estão presentes, sendo aqui elucidados. O percentual de população acima do limiar da pobreza está presente para os anos de 1980 e 2000, havendo uma diminuição relativa nesses 20 anos. Em 1980, eram 98,0\% da população para 93,0\% em 2000.

Os números de habitações cuja benfeitoria foi feita utilizando 'materiais permanentes que propiciem uma habitação segura e duradoura' revelam ser os anos de 1980 aqueles que possuem o melhor percentual de famílias com acesso ao tipo de benfeitoria colocado, ou seja, 95\%\%. Os anos de 1970 possuem o maior índice encontrado entre os municípios aqui analisados, 89\% e nos anos de 1990 ocorre uma queda semelhante aos demais municípios, ficando o número de famílias atendidas por volta de $70 \%$.

Curiosamente, o índice 'Habitação cuja posse esteja assegurada', demonstra um perfil do município pior do que o dos demais analisados. Considerando que todos os demais indicadores estão em níveis de qualidade ambiental superior aos dos outros municípios, tal fato é discrepante dos demais dados. Nas décadas de 1970 e 1980 o índice se mantém em 42\% caindo para $31,3 \%$ nos anos de 1980 e com uma ascensão em 2000, quando fica no patamar dos $51,5 \%$ da população. 
No indicador da categoria 7 - 'Adequação quanto à concentração humana densidade população área urbanizada', tem-se 53,1 hab/ha, uma densidade considerada baixa para ocupação humana de clima tropical. Considerando-se a área total do município $544,3 \mathrm{~km}^{2}$ e sua população de 135.627 habitantes, tem-se uma densidade de 2,49 hab/ha. Ao que tudo indica, a concentração fundiária e a falta de acesso a terra, já exposta ao longo do texto descritivo do município são aqui evidenciadas. Sendo assim, os vazios urbanos presentes no município rebaixam sua potencialidade a sustentabilidade urbana pela longérrima extensão que impõe para 0 abastecimento quanto à infra-estrutura. ${ }^{38}$

Em relação ao estabelecido por Dias (2002), a área disponível por habitante no planeta é hoje um hectare para cada habitante. O município encontra-se acima do parâmetro estabelecido.

A Matriz de Qualidade de Ambiente Urbano - Composição Tonal permite que seja percebida a totalidade das informações, mesmo que apenas qualitativamente. Percebe-se do lado direito do quadro a melhora da qualidade ambiental, sendo que toda a última coluna, referente ao ano de 2000 , apresenta dados mais adequados à constituição de um ambiente urbano sustentável, conforme parâmetros necessários consolidados pela matriz. A leitura que pode ser feita é a de que a situação ambiental tende a uma melhora.

38 Quanto ao potencial de adensamento da área contida no Perímetro Urbano, pode-se ressaltar que $43 \%$ dos lotes existentes encontram-se desocupados, representando 14.643 unidades, muitos deles implantados em áreas já servidas de infra-estrutura. Além disso, os vazios urbanos e áreas ociosas existentes neste perímetro, aptos ao parcelamento, poderiam comportar aproximadamente a implantação de 40.000 de 360,00 m². (PREFEITURA..., 1992a, p. 157).

Organização para o planejamento: 27 setores denominados regiões urbanas homogêneas (RUH).

\begin{tabular}{|c|l|l|l|l|}
\hline Lotes Vagos & \multicolumn{1}{|c|}{ Áreas parceladas } & \multicolumn{2}{|c|}{ Vazios Urbanos } & Áreas não parceláveis \\
\hline $7.000 \mathrm{ha}$ & $2.444 \mathrm{ha}$ & 3.056 & 1.500 & $783 \mathrm{ha}$ \\
\hline
\end{tabular}

Este perímetro, embora contenha aproximadamente $22 \%$ de áreas impróprias à ocupação, possui capacidade para abrigar uma população aproximada de 5.000 .000 a 1.000 de habitantes, com densidades médias de 100 a 200 hab/ha. Observa-se que a análise da ocupação territorial demonstra a existência de consideráveis vazios urbanos intercalados a áreas já parceladas que, somados ao elevado índice de lotes vagos, resultam em aglomerados de baixas densidades, onerando o custo dos serviços públicos oferecidos e tomando ociosa grande parte da infra-estrutura instalada. (PREFEITURA..., 1992a, p. 205). 
Considerando que foi possível obter apenas 21 dados dos 140 que foram propostos para a matriz total, tem-se uma estatística que não chega a ser determinante da sustentabilidade do ambiente da cidade, pois 21 dados obtidos correspondem a $15 \%$ do total considerado necessário para análise do município.

Para o caso de Poços de Caldas, 18 dos dados estão classificados como estando entre as classes 'média' e 'adequada qualidade' do ambiente urbano, o que equivale a $12,8 \%$ do total, e dentre estes 18,10 dos elementos levantados estão classificados como 'adequada' qualidade do ambiente urbano.

Considerando o universo total como sendo o dos 21 dados obtidos, a sustentabilidade pode ser mais facilmente aceita. Sendo 18 o número de dados entre as classes 'média' e 'adequada qualidade' do ambiente urbano, tem-se 85,7\% e quanto aos 10 dos elementos classificados como 'adequada qualidade' do ambiente urbano, tem-se $47,6 \%$ dos dados.

Tendo como referencial apenas os dados obtidos, o ambiente poderia ser considerado com tendendo à adequação. Como no entanto, o universo de dados sem resposta é muito grande - o que significa uma provável negligência em relação ao seu comportamento - a qualidade estaria comprometida.

Considerando também algumas informações sobre indicadores apresentadas pelo IDH-Municipal (PNUD; IPEA; FJP, 2003):

No período 1991-2000, o índice de Desenvolvimento Municipal (IDHM) de Poços de Caldas cresceu 8,10\% passando de 0,778 em 1991 para $0,841 \mathrm{em} 2000$.

A dimensão que mais contribuiu para este crescimento foi a Longevidade, seguida pela Renda e pela Educação (...).

Se mantivesse esta taxa de crescimento do IDH, o município levaria 9,9 anos para alcançar São Caetano do Sul (SP), o município como o melhor IDH do Brasil $(0,919)$ e 0,0 anos para alcançar Poços de Caldas (MG), o município com o melhor IDH do Estado $(0,841)$.

Segundo a classificação do PNUD, o município está entre as regiões consideradas de alto desenvolvimento humano (IDH maior 0,8) (PNUD; IPEA; FJP, 2003) 
A renda per capta média do município cresceu $47,53 \%$, passando de $\mathrm{R} \$ 295,24$ em 1991 para $\mathrm{R} \$ 435,56$ em 2000. A pobreza (medida pela proporção de pessoas com renda domiciliar per capta inferior a $R \$ 75,50$, equivalente à metade do salário mínimo vigente em agosto de 2000) diminuiu 38,33\%, passando de $14,5 \%$ em 1991 para 9,0\% em 2000. O índice de Gini de Poços de Caldas demonstra um aumento na concentração de renda, sendo 0,52 em 1991 e passando a 0,56 em 2000. A classificação exposta acima, de 'regiões consideradas de alto desenvolvimento humano' está em acordo com a qualidade de ambiente resultante da análise da Matriz de Indicadores de Qualidade de Vida Urbana.
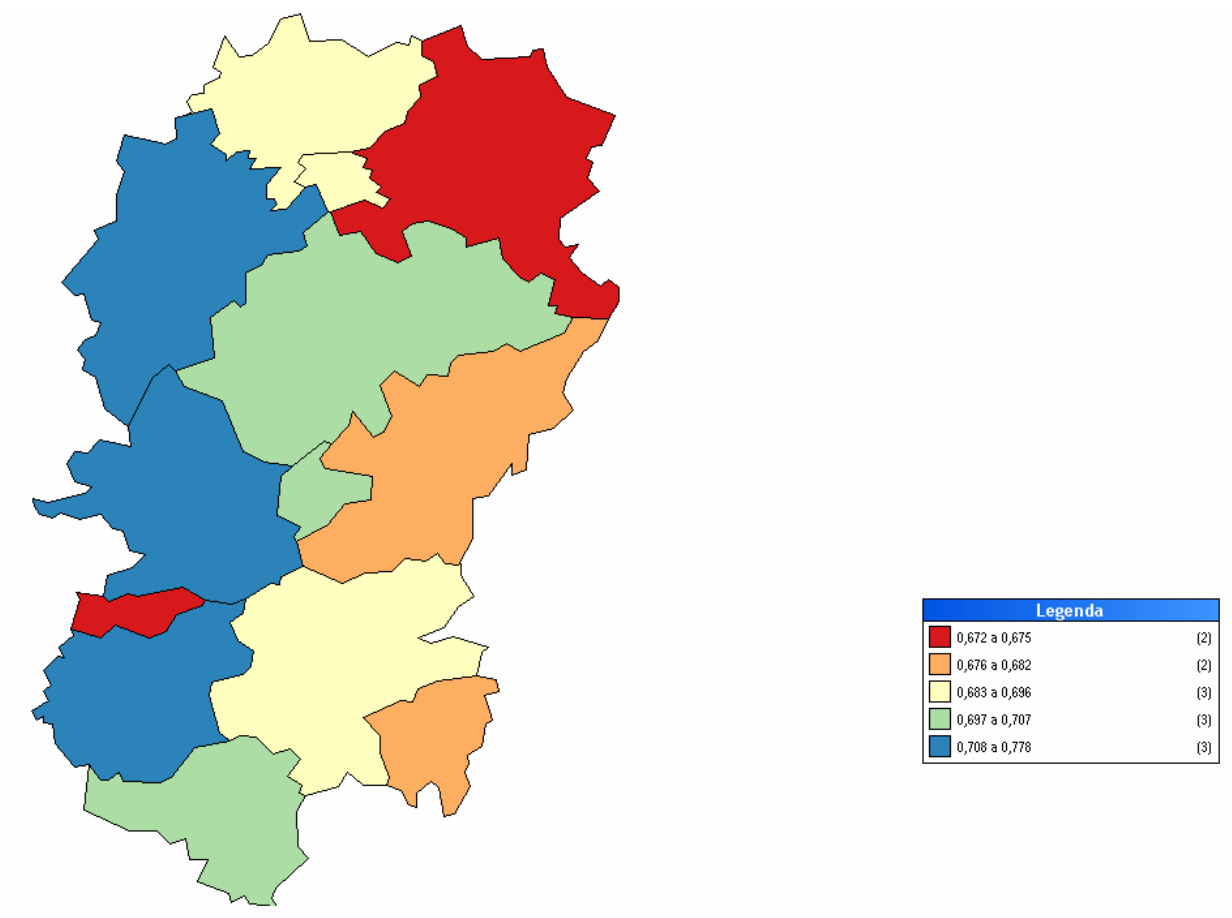

Mapa 22 - Índice de desenvolvimento humano dos municípios da microrregião de Poços de Caldas/MG, 1991.

FONTE: PNUD; IPEA; FJP, 2003. 


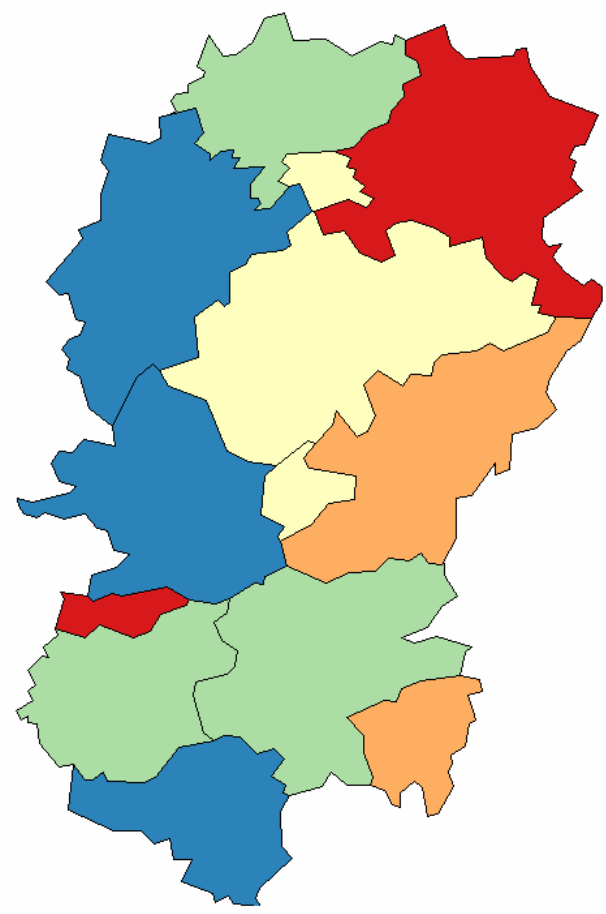

\begin{tabular}{|c|c|}
\hline \multicolumn{2}{|c|}{ Legenda } \\
\hline$\square_{0,747}$ a 0,759 & (2) \\
\hline$\square 0,760$ • 0,770 & (2) \\
\hline$\square 0,771$ a 0,782 & (3) \\
\hline$\square 0,783$ a 0,798 & (3) \\
\hline$\square 0,799 \mathrm{a} 0,841$ & (3) \\
\hline
\end{tabular}

Mapa 23 - Índice de desenvolvimento humano dos municípios da microrregião de Poços de Caldas/MG, 2000.

FONTE: PNUD; IPEA; FJP, 2003.

Os mapas 22 e 23 permitem ver a Microrregião e sua melhoria entre os anos de 1991 e 2000, tendo o município de Poços de Caldas na extremidade esquerda superior, em cor azul. 


\subsection{UBERLÂNDIA}

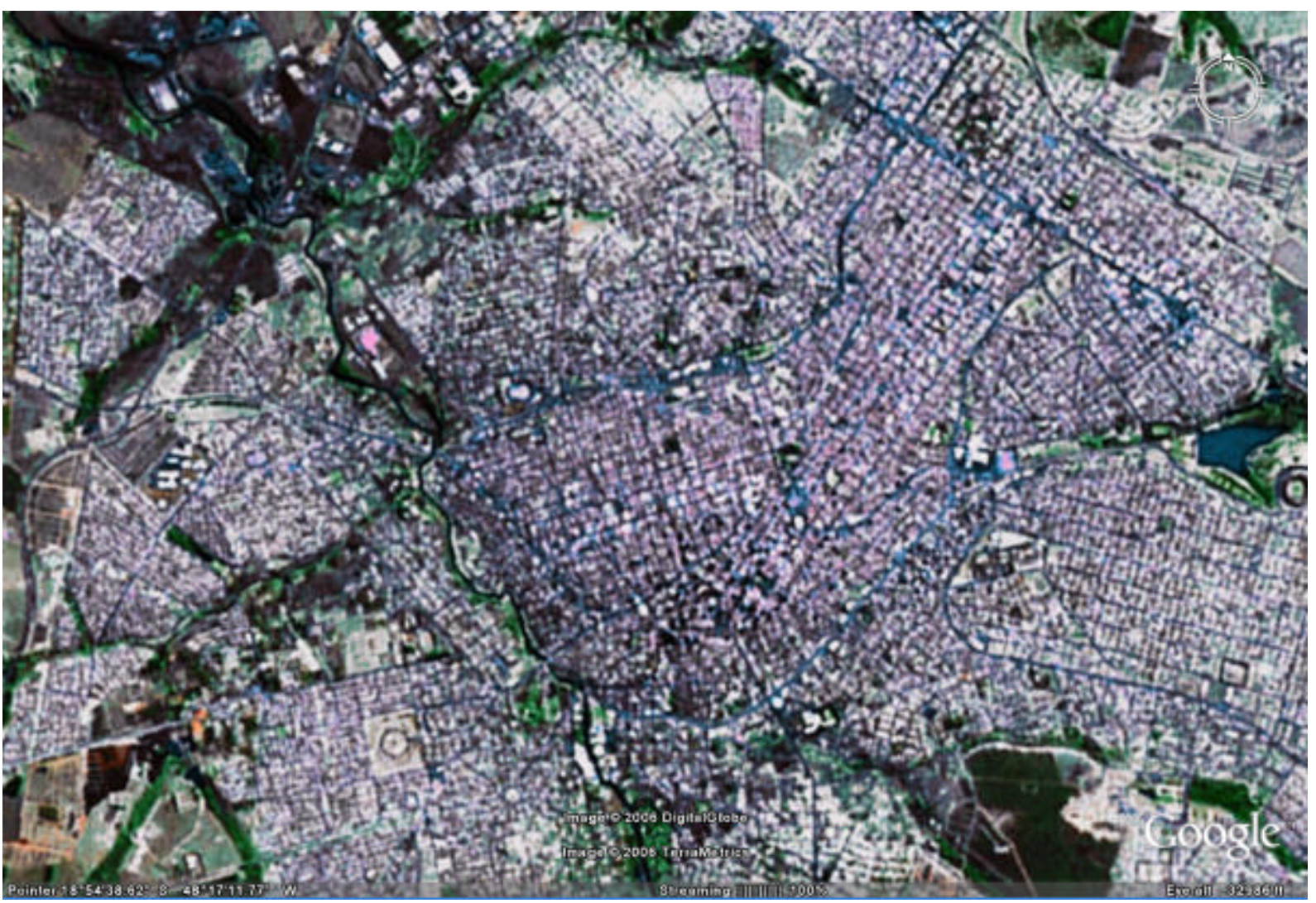

Figura 5 - $\quad$ Vista aérea de Uberlândia/MG (altitude 10,05 km).

FONTE: Google Earth, Digital Globe. Image @ 2006.

Uberlândia $^{39}$ tem sob sua influência 26 municípios e dela irradiam diversos

eixos de ligação à Brasília, São Paulo, Belo Horizonte, Patos de Minas, Montes

Claros e à fronteira com Mato Grosso do Sul.

39 Bartolomeu Bueno da Silva, o "Anhangüera", abriu em 1722 a primeira estrada no "Sertão da Farinha Podre", quando por lá passou com destino a Goiás. A estrada ficou conhecida durante muitos anos por "Estrada do Anhangüera" e depois por "Estrada de Goiás" e "Estrada Real". A primeira "bandeira" que perlustrou terras do atual Município de Uberlândia teve a chefia do Sargento-Mor Antônio Eustáquio da Silva e Oliveira e contou com a participação de Januário Luís da Silva, Pedro Gonçalves da Silva, José Gonçalves Heleno, Manuel Francisco Ferreira e outros. Esse primeiro devassamento, com vistas à ocupação da terra, deve ter-se processado entre 1810 e 1812 . Seguiu-se a concessão das primeiras sesmarias, nas bacias dos rios Uberaba-legítimo (Uberabinha) e Abelhas (atual Araguari), aos povoadores que se constituíram nos troncos das famílias Peixoto, Pereira, Carrejo, Rezende, Barbosa e outras. Daí em diante, de muitos pontos do Julgado do Desemboque, de Minas Gerais e Goiás, estabeleceu-se corrente imigratória quase contínua, em grande parte composta de conhecidos ou parentes daqueles sesmeiros. Em 1846, por iniciativa de Felisberto Alves Carrejo e Francisco Alves Pereira da Rocha, erigiu-se uma capela, sendo primeiro padre José Martins Carrejo, filho de Felisberto Alves Carrejo. O lugar escolhido para o arraial chamava-se São Pedro. Consta que esse topônimo se originou de uma inscrição, em que se lia "29 de junho" (dia do Santo), gravada em relevo na superfície de tronco secular, às margens de um córrego afluente do rio Uberabinha. Segundo a tradição, chamava-se Uberaba esse rio ou "Uberabalegítimo". Uberaba, em idioma indígena, significa água que brilha. 


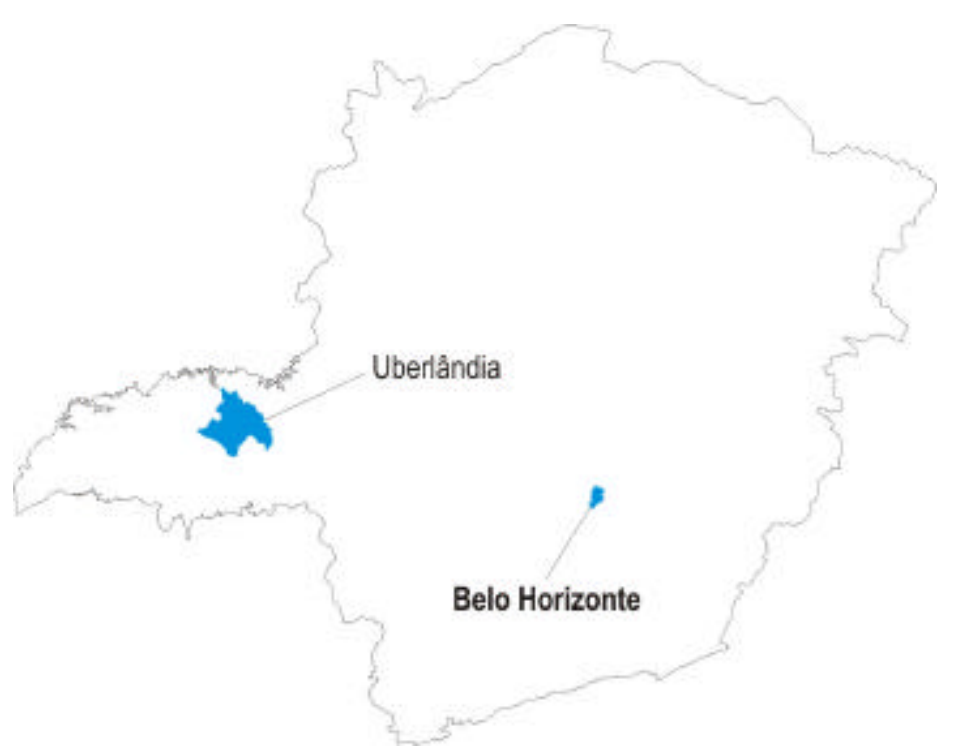

Mapa 24 - $\quad$ Situação do município de Uberlândia/MG no Estado.

FONTE: IGA. 1999.

Marcada pela presença das rodovias que configuram uma estrela cujo centro é Uberlândia, a cidade sofre polarização macrorregional por São Paulo (FJP, 1980d, p. 4).

\section{Quadro 23 - Microrregião de Uberlândia/MG.}

Macrorregião Triângulo Mineiro

Microrregião: Uberlândia

Municípios: Araguari, Araporã, Canápolis, Cascalho Rico, Centralina, Indianópolis, Monte Alegre de Minas, Prata, Tupaciguara, Uberlândia

FONTE: ALMG, 2006.

O crescimento de sua população se faz a partir dos anos 50 , passando a ter a maior população da região do Triângulo em 1970. Possui a maior proporção de População Economicamente Ativa (PEA) da região. (FJP, 1980d, p. 8).

Historicamente, sua primeira ocupação se deu no ciclo do gado mais ou menos concomitantemente com o ciclo do ouro quando os rebanhos vindos do nordeste subindo o São Francisco alcançavam os campos da região noroeste mineira e daí passaram ao Triẩngulo. Devido à dificuldade de comunicação com o centro de Minas, esta região permaneceu longo tempo escassamente povoada e muito mais ligada à economia paulista que à Mineira. A cidade de Uberlândia originada da vizinha Uberaba, já no final do século passado exerceu o papel de entreposto entre os grandes centros especialmente São Paulo e o sertão ocidental - isto é o Sul de Goiás e o Mato Grosso. Era o que se denominava a Boca do Mato de onde se alcançavam os povoados e fazendas do interior. (FJP, 1980d, p. 26). 
Sendo assim, Uberlândia sempre foi um entreposto entre grandes centros. Com o aparelhamento de sua infra-estrutura devido aos recursos advindos da atividade comercial. Uberlândia começou a concentrar a produção agrícola da região do Sul de Goiás e parte noroeste de Minas para beneficiamento e distribuição. A construção de Brasília fez com que a cidade tornasse-se passagem obrigatória entre São Paulo e a nova capital. Cabe ressaltar que esta atividade tipicamente terciária fez com que ainda em 1970, a população urbana do município fosse de $94,5 \%$. (FJP, 1980d, p. 38 e 43), sendo Uberlândia o segundo pólo comercial do estado, só antecedido pela capital. Com vocação agrária, possuía um parque industrial voltado para o beneficiamento destes produtos.

A expansão urbana ocorreu em direção às rodovias federais, resultando em formação de vazios intersticiais e baixas densidades, em loteamentos cuja ocupação não se encontra completa ou é feita de forma rarefeita.

Os altos custos de urbanização associados à expansão urbana desconcentrada tem como reflexo, não somente elevar o preço das moradias envolvidas, mas também, em virtude da proximidade de serviços tais como de rede de água o escola, valorizar às áreas circunvizinhas, além de encarecer as habitações semelhantes que apresentam melhor localização face ao centro da cidade. O crescimento urbano orientado para a ocupação de áreas adjacentes à faixa urbana compacta, reduziria os custos de urbanização beneficiando-se, ainda, da proximidade de equipamentos comunitários e outros serviços, sem acarretar modificações expressivas nos valores imobiliários. (FJP, 1980d, p. 77).

Os saldos migratórios para a cidade foram positivos na maioria dos períodos recenseados, diminuindo a população apenas no período anterior a 1960, quando perde população para Brasília. O município possui uma característica de atrair mão de obra temporária para as atividades agrárias.

O Município participou de dois dos três convênios firmados entre o CNDU e o estado de Minas Gerais. No primeiro deles foi firmado um convênio de $\operatorname{Cr} \$ 51$ bilhões, sendo $\operatorname{Cr} \$ 12$ bilhões destinados ao planejamento e administração 
municipal e $\mathrm{Cr} \$ 39$ bilhões destinados a infra-estrutura viária e transporte. A União aloca apenas $\mathrm{Cr} \$ 30$ bilhões ao programa viário, ficando os demais $\operatorname{Cr} \$ 9$ bilhões a cargo do estado de Minas Gerais, enquanto o município utiliza os Cr\$12 bilhões para elaboração do Plano da Lei de Uso do Solo.

O segundo convênio é de 1982 alocando Cr\$154 bilhões distribuídos entre planejamento e administração, infra-estrutura social e infra-estrutura econômicas, sendo que o estado de Minas arca com Cr\$150 bilhões, tendo a responsabilidade pela implantação, com a construção de três centros de saúde, um centro de bairro, uma micro-unidade de produção e a abertura de crédito para micro-empresas.

Tabela 12 - Investimentos urbanos por fonte em Uberlândia/MG. Recursos em Cr\$1.000,00 - 1978/1979 (1을 semestre).

\begin{tabular}{|c|c|c|c|c|c|c|}
\hline \multirow[b]{2}{*}{ PROJETOS } & \multirow{2}{*}{$\begin{array}{l}\text { Órgão } \\
\text { executor }\end{array}$} & \multirow[b]{2}{*}{ Município } & \multirow[b]{2}{*}{ Estado } & \multicolumn{2}{|c|}{ União } & \multirow[b]{2}{*}{ Total } \\
\hline & & & & $\begin{array}{l}\text { FNDUI } \\
\text { FDTU }\end{array}$ & $\begin{array}{c}\text { FNDUI } \\
\text { OP }\end{array}$ & \\
\hline Planejamento e Administração & & & & & & $12.000,0$ \\
\hline $\begin{array}{l}\text { Elaboração do plano físico territorial (Lei de Uso do } \\
\text { Solo) }\end{array}$ & & $12.000,0$ & & & & $12.000,0$ \\
\hline Infra-estrutura Viária e Transportes & & & $9.000,0$ & $30.000,0$ & & $39.000,0$ \\
\hline $\begin{array}{l}\text { Projeto de Sete Obras de Arte Especiais do Anel de } \\
\text { Contorno (trecho à direita) } 310 \mathrm{ml}\end{array}$ & DER & & & $1.600,0$ & & $1.600,0$ \\
\hline $\begin{array}{l}\text { Implantação de } 13 \text { km do Anel de Contorno (trecho à } \\
\text { direita) }\end{array}$ & DER & & $9.000,0$ & $28.400,0$ & & $37.400,0$ \\
\hline TOTAL & & $12.000,0$ & $9.000,0(1)$ & $30.000,0$ & & $51.000,0(2)$ \\
\hline
\end{tabular}

(1) Este total não consta da E.M. 302/78 de 31/07/78

(2) Deste total Cr\$9.000.000,00 não constam da EM 302/78 de 03/07/78

FONTE: Convênio 32/78 do Programa de Investimentos Urbanos para Capitais e Cidades de Porte Médio, Estado de Minas Gerais.

Tabela 13 - Investimentos urbanos por fonte em Uberlândia/MG. Recursos em CR\$ 1.000,00 - 1982.

\begin{tabular}{|c|c|c|c|c|c|c|}
\hline \multicolumn{2}{|r|}{ Projetos } & Unidade Executora & Município & Estado & União & Total \\
\hline \multirow[t]{2}{*}{$1-$} & Planejamento e Administração & & 888 & & 3.553 & 4.441 \\
\hline & 1. Reforço institucional às Prefeituras & Prefeitura e FJP & 888 & & 3.553 & 4.441 \\
\hline \multirow[t]{3}{*}{$11-$} & Infra-estrutura Social & & & 64.928 & & 64.928 \\
\hline & 1. Construção de três Centros de Saúde & SES/MG & & 19.024 & & 19.024 \\
\hline & 2. Construção de um Centro de Bairro & Prefeitura & & 45.904 & & 45.904 \\
\hline \multirow[t]{3}{*}{ III - } & Infra-estrutura econômica & & & 84.899 & & 84.899 \\
\hline & $\begin{array}{l}\text { 1. Construção de uma micro-unidade de } \\
\text { produção }\end{array}$ & SETAS/MG & & 6.371 & & 6.371 \\
\hline & 2. Crédito às micro empresas & BDMG & & 78.528 & & 78.528 \\
\hline \multicolumn{2}{|c|}{ TOTAL } & & 888 & 149.827 & 3.553 & 154.268 \\
\hline
\end{tabular}

FONTE: Convênio 185/SG/82 do Programa Estadual de Centros Intermediários, Minas Gerais. 
FAUUSP (1984) faz a seguinte afirmação, para o caso de Uberlândia, mas que é muito interessante no conjunto de todas os convênios firmados com as prefeituras analisadas e pelo histórico de atuação da CNDU:

O que pode-se perceber através de avaliação desses convênios é que no primeiro período o interesse do programa volta-se bastante mais para a questão do planejamento local, e a tentativa é incentivar o município a desenvolver uma prática de planejamento. O restante do convênio fica por contar de investimentos do FDTU. Já no segundo período percebe-se uma vinculação maior com os objetivos do Programa Estadual de Centros Intermediários, sendo o Estado responsável pela quase totalidade dos recursos conveniados. Os projetos, neste caso, se voltam para infra-estrutura social e econômica. (FAUUSP, 1984, p. 78).

E para o caso específico:

A tentativa aqui é justamente a de cumprir com o objetivo de dinamização de pólos de desenvolvimento no interior, reforçando no caso de Uberlândia seu papel de intermediação entre as metrópoles paulistas e mineira. (FAUUSP, 1984, p. 78).

No diagnóstico apresentado pela FJP para o PROECI havia a indicação de que os pobres de Uberlândia contavam com precárias condições de atendimento quanto à infra-estrutura urbana. Pela pesquisa domiciliar feita pelo programa, 54\% da população não possuía abastecimento de água pela rede pública e $69 \%$ não estava ligada à rede de esgotos sanitários. Apenas $6 \%$ era atendido por coleta de lixo, $49 \%$ tinha energia elétrica, tendo um percentual de $80 \%$ com rede a porta (FJP, 1980d, p. 113).

A Matriz de Indicadores apresentada no quadro 24 permite que seja vislumbrado o aumento da qualidade de vida. São os seguintes dados que podem nos servir de base para a averiguação da melhoria da qualidade de vida urbana advinda das ações de tais políticas públicas, embora não sejam elas as únicas explicações. 
Quadro 24 - Matriz de Indicadores de Qualidade de Vida Urbana - Uberlândia - Matriz com o total dos indicadores

\begin{tabular}{|c|c|c|c|c|c|c|c|c|}
\hline Grupo & & Indicadores & & 1960 & 1970 & 1980 & 1990 & 2000 \\
\hline \multirow{2}{*}{ 1. Abastecimento domiciliar de água } & \multirow{2}{*}{\multicolumn{3}{|c|}{$\begin{array}{l}\text { Acesso à água potável } \\
\text { Proporcỗes de domicilios com melhoria de acesso ao abastecimento de água }\end{array}$}} & $42,4 \%$ & $61,2 \%$ & $89,4 \%$ & $99,9 \%$ & $97,6 \%$ \\
\hline & & & & & $\begin{array}{lll}18,8 \% \\
\end{array}$ & $28,2 \%$ & $10,5 \%$ & $-2,3 \%$ \\
\hline \multirow{7}{*}{ 2. Saneamento básico } & \multicolumn{3}{|c|}{ Coleta de água servida } & $36,2 \%$ & $48,3 \%$ & $78,8 \%$ & $91,4 \%$ & $96,0 \%$ \\
\hline & \multirow{2}{*}{\multicolumn{3}{|c|}{ 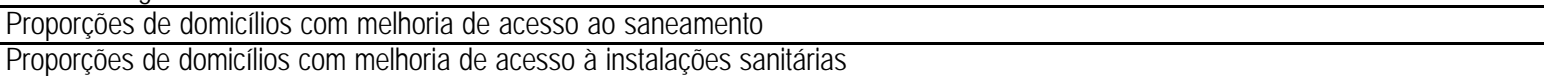 }} & & $12,1 \%$ & $30,5 \%$ & $12,6 \%$ & $4,6 \%$ \\
\hline & & & & & & & & \\
\hline & \multicolumn{3}{|c|}{ Aguas residuais tratadas } & & & - & - & \\
\hline & \multicolumn{3}{|c|}{ Recolhimento regular de dejetos sólidos } & - & & - & - & $97,5 \%$ \\
\hline & \multirow{2}{*}{\multicolumn{3}{|c|}{$\begin{array}{l}\text { Adequada disposição do lixo } \\
\end{array}$}} & - & & - & - & \\
\hline & \multirow{2}{*}{\multicolumn{3}{|c|}{$\begin{array}{l}\text { Promoção integrada de infra-estrutura ambiental: água, saneamento, drenagem e manejo de resíduos sólidos } \\
\text { Percentual de populacão acima do limiar da pobreza }\end{array}$}} & & & & & \\
\hline \multirow{10}{*}{ 3. Habitação } & & & & & & $98,4 \%$ & - & $90,4 \%$ \\
\hline & \multicolumn{3}{|c|}{$\begin{array}{l}\text { Percentual de população acima do limiar da pobreza } \\
\text { |Area suficiente para viver }\end{array}$} & & & & & \\
\hline & \multirow{2}{*}{ Densidade } & \multicolumn{2}{|l|}{ Proporcãão de domicilios com menos de três pessoas por cômodo } & & & & & $77,8 \%$ \\
\hline & & \begin{tabular}{|l} 
Utilização materiais permanentes que propiciem uma habitação segura e duradoura \\
\end{tabular} & & - & $83,7 \%$ & $97,9 \%$ & $55,7 \%$ & \\
\hline & \multirow{2}{*}{ Benfeitoria } & Conexôes hidro-sanitárias internas ao domicílio & & & & & & $98,8 \%$ \\
\hline & & Construída fora de áreas de risco & & - & & & & \\
\hline & \multirow{4}{*}{ Posse } & Habitação cuja ocupação esteja assegurada & & & $50,9 \%$ & $46,9 \%$ & $26,6 \%$ & $63,6 \%$ \\
\hline & & \begin{tabular}{|l|l} 
Financiamento de habitações \\
\end{tabular} & & & & & & \\
\hline & & Relação preço da terra versus ingresso no mercado de terra & & & & & & \\
\hline & & Preço da habitação e coeficiente de habitações ingressadas no montante total & & & & & & \\
\hline \multirow{5}{*}{ 4. Desenvolvimento técnico-tecnológico } & \multicolumn{3}{|c|}{ Aperfeiçoados o manejo dos assentamentos humanos } & & & - & - & - \\
\hline & \multirow{2}{*}{\multicolumn{3}{|c|}{$\begin{array}{l}\text { Sistemas sustentáveis de energia e transporte nos assentamentos humanos } \\
\text { Prevencão de desastres e instrtumentos de mititacăo }\end{array}$}} & - & & - & - & - \\
\hline & & & & - & $F$ & - & {$[-$} & - \\
\hline & \multicolumn{3}{|c|}{ 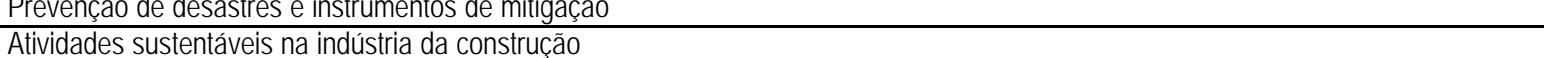 } & & & 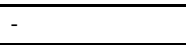 & - & - \\
\hline & \multicolumn{3}{|c|}{ Capacitaçẫo institucional e técnica para o avanço dos assentamentos humanos } & - & - & - & - & - \\
\hline \multirow{2}{*}{ 5. Infra-estrutura viária } & \multirow{2}{*}{\multicolumn{3}{|c|}{\begin{tabular}{|l|l|} 
Modos de transporte \\
Sistemas sustentíveis de transporte
\end{tabular}}} & & & & & \\
\hline & & & & & & 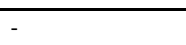 & -1 & \\
\hline \multicolumn{4}{|c|}{ 6. Existência de áreas verdes suficientes ao exerćício das atividades de lazer } & - & - & - & - & \\
\hline \multicolumn{4}{|c|}{\begin{tabular}{|l|l} 
7. Adequação quanto à concentraçãao humana - Densidade populaçẫol área urbanizada \\
\end{tabular}} & - & - & - & - & 36,12 hab/ha \\
\hline \multicolumn{9}{|c|}{\begin{tabular}{l|l} 
& $1,2 \mathrm{hab} / \mathrm{ha}$ \\
\end{tabular}} \\
\hline \multirow{2}{*}{\multicolumn{2}{|c|}{\begin{tabular}{|l|} 
Tamanho da população \\
Número de famililas \\
\end{tabular}}} & \begin{tabular}{l|l} 
& 87.678 \\
\end{tabular} & 240.967 & & 337.061 & & 501.214 & \\
\hline & & 25.826 & 53.553 & & \begin{tabular}{|l|l|}
94.237 \\
\end{tabular} & & 144.461 & \\
\hline
\end{tabular}

\section{Quadro 25 - Matriz de Indicadores de Qualidade de Vida Urbana - Uberlândia - 1ª ordenação dos dados}

\begin{tabular}{|c|c|c|c|c|c|c|}
\hline Grupo & Indicadores & 1960 & 1970 & 1980 & 1990 & 2000 \\
\hline 1. Abastecimento domiciliar de água & Acesso à água potável & $42,4 \%$ & $61,2 \%$ & $89,4 \%$ & $99,9 \%$ & $97,6 \%$ \\
\hline \multirow{2}{*}{ 2. Saneamento básico } & Coleta de água servida & $36,2 \%$ & $48,3 \%$ & $78,8 \%$ & $91,4 \%$ & $96,0 \%$ \\
\hline & \begin{tabular}{|l|l|l} 
Recolhimento regular de dejetos sólidos \\
\end{tabular} & & & & & $97,5 \%$ \\
\hline \multirow{5}{*}{ 3. Habitação } & Percentual de população acima do limiar da pobreza & - & - & $98,4 \%$ & - & $90,4 \%$ \\
\hline & \begin{tabular}{|l|l} 
Densidade & Proporçãa de domicilios com menos de três pessoas por cômodo \\
\end{tabular} & - & & & & $77,8 \%$ \\
\hline & Utilizaçã̃o materiais permanentes que propiciem uma habitação segura e duradoura & & $83,7 \%$ & $97,9 \%$ & $55,7 \%$ & \\
\hline & Conexôes hidro-sanitárias internas ao domićlilio & & & & & $98,8 \%$ \\
\hline & Habitação cuja ocupação esteja assegurada & & $50,9 \%$ & $46,9 \%$ & $26,6 \%$ & $63,6 \%$ \\
\hline
\end{tabular}

\section{Quadro 26 - Matriz de Indicadores de Qualidade de Vida Urbana - Uberlândia - Composição tonal}

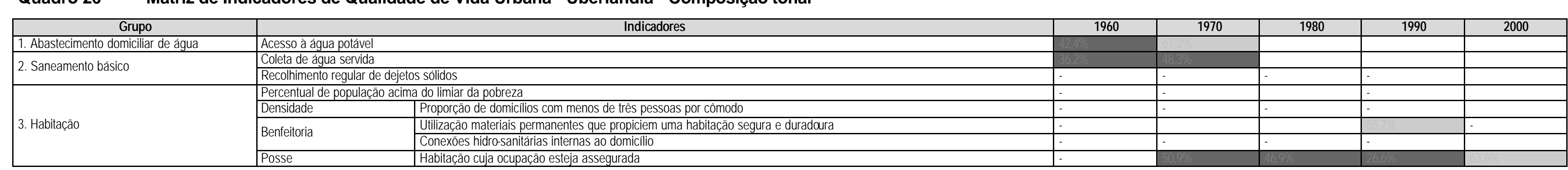


Constata-se que, considerando os indicadores de informação existentes e presentes, a situação ambiental do município, no caso, Uberlândia, tendeu a uma ascensão de qualidade, haja vista a análise da última coluna da matriz, que para o ano de 2000, que apresenta uma apreciação de valoração prioritariamente superior a $50 \%$.

Na categoria 1 - 'Abastecimento domiciliar de água', pode-se dizer que a melhoria efetiva ocorre exatamente no período de incidência das políticas públicas e seus investimentos. Dos anos de 1970 para os anos de 1990, o aumento de famílias abastecidas por água da rede geral de abastecimentos é de $38,7 \%$, enquanto o crescimento do número de famílias aumenta 3,6 vezes, o que demonstra não ser suficiente ao crescimento populacional o aumento da prestação do serviço. Em 1990, chega-se a um atendimento de $99,9 \%$ da população. A coleta de água servida, apresentada pela categoria 2 - 'Saneamento básico', também tem significativa melhora no mesmo período, passando a abranger $91,4 \%$ das famílias na década de 1990, tendo começado com um horizonte de 48,3\% das famílias nos anos de 1970. No período compreendido entre os anos de 1970 e 1990, foi quando da maior proporção de domicílios com melhoria de acesso ao saneamento para este caso, sendo de cerca de $43,1 \%$.

Os dados para o ano de 2000 revelam uma adequada qualidade ambiental para os parâmetros adotados por este trabalho, pois ambos, abastecimento de água e coleta de esgoto apresentam valores relativos superiores a $75 \%$, conforme estabelecido na metodologia deste trabalho.

Devidamente considerado deve ser o fato da inexistência de uma série histórica de informações para o dado de recolhimento regular de dejetos sólidos. Este dado só está presente para 2000, apresentando 97,5\% das famílias. 
Para a categoria 3 - 'Habitação', alguns dados estão presentes, sendo aqui elucidados. O percentual de população acima do limiar da pobreza está presente para os anos de 1980 e 2000, havendo uma diminuição relativa nesses 20 anos. Em 1980, eram 98,4\% da população para 90,4\% em 2000. Estes números possivelmente apontam para o caráter do empobrecimento geral da população do município e do país.

O número de habitações cuja benfeitoria foi feita utilizando 'materiais permanentes que propiciem uma habitação segura e duradoura' indicam para a atuação das políticas urbana, neste caso provavelmente provenientes da existência do $\mathrm{BNH}$, que tem suas atividades encerradas nos anos 1980 , período com maior número de famílias com acesso ao tipo de benfeitoria colocado, ou seja, 97,9\%. Nos anos de 1970 o percentual era de $83,7 \%$ e nos anos $90,55,7 \%$ do total de famílias.

O índice 'Habitação cuja ocupação esteja assegurada' tem nos anos de 1970 um percentual de 59,9\% do número de domicílio, caindo para 46,9\% nos anos 80 e para 26,6 nos anos 90 . Em 2000, o percentual é o mais elevado do período de analise, $63,6 \%$ do total de domicílios.

No indicador da categoria 7 - 'Adequação quanto à concentração humana densidade população área urbanizada', tem-se 36,12 hab/ha, uma densidade considerada muito baixa para ocupação humana de clima tropical, que confirma a concentração fundiária e a falta de acesso a terra, já exposta ao longo do texto descritivo do município. Sendo assim, os vazios urbanos presentes no município rebaixam sua potencialidade a sustentabilidade urbana pela longérrima extensão que impõe para o abastecimento quanto à infra-estrutura. Considerando-se a área total do município $4.103,4 \mathrm{~km}^{2}$ e sua população de 501.214 habitantes, tem-se uma densidade total para o município de 1,2 hab/ha. Em relação ao estabelecido por Dias 
(2002), a área disponível por habitante no planeta é hoje um hectare para cada habitante. O município encontra-se próximo ao estabelecido.

A Matriz de Qualidade de Ambiente Urbano - Composição Tonal permite que seja percebida a totalidade das informações, apenas qualitativamente. Percebe-se do lado direito do quadro a melhora da qualidade ambiental, sendo que toda a última coluna, referente ao ano de 2000, apresenta dados mais adequados à constituição de um ambiente urbano sustentável, conforme parâmetros necessários consolidados pela matriz. A leitura que pode ser feita é a de que a situação ambiental tende a uma melhora.

Considerando que foi possível obter apenas 21 dados dos 140 que foram propostos para a matriz total, tem-se uma estatística que não chega a ser determinante da sustentabilidade do ambiente da cidade, pois 21 dados obtidos correspondem a $15 \%$ do total considerado necessário para análise do município.

Para o caso de Uberlândia, 16 dos dados estão classificados como estando entre as classes 'média' e 'adequada qualidade' do ambiente urbano, o que equivale a $11,4 \%$ do total, e dentre estes 16,13 dos elementos levantados estão classificados como 'adequada' qualidade do ambiente urbano, o que corresponde a apenas $9,2 \%$ do total.

Considerando o universo total como sendo o dos 21 dados obtidos, a sustentabilidade pode ser mais facilmente aceita. Sendo 16 o número de dados entre as classes 'média' e 'adequada qualidade' do ambiente urbano, tem-se 76,2\% e quanto aos 13 dos elementos classificados como 'adequada qualidade' do ambiente urbano, tem-se $61,9 \%$ dos dados, o mais alto índice encontrado entre os municípios aqui analisados.

Considerando também algumas informações sobre indicadores apresentadas pelo IDH-Municipal (PNUD; IPEA; FJP, 2003): 
No período 1991-2000, o índice de Desenvolvimento Municipal (IDHM) de Uberlândia cresceu 6,68\% passando de 0,778 em 1991 para 0,772 em 2000.

A dimensão que mais contribuiu para este crescimento foi a Educação, seguida pela Longevidade e pela Renda (...)

Se mantivesse esta taxa de crescimento do IDH, o município levaria 13,6 anos para alcançar São Caetano do Sul (SP), o município como o melhor IDH do Brasil $(0,919)$ e 1,8 anos para alcançar Poços de Caldas (MG), o município com o melhor IDH do Estado $(0,841)$.

Segundo a classificação do PNUD, o município está entre as regiões consideradas de alto desenvolvimento humano (IDH maior que 0,8) (PNUD; IPEA; FJP, 2003).

A renda per capta média do município cresceu $27,11 \%$, passando de $\mathrm{R} \$ 306,29$ em 1991 para $\mathrm{R} \$ 389,32$ em 2000. A pobreza (medida pela proporção de pessoas com renda domiciliar per capta inferior a $\mathrm{R} \$ 75,50$, equivalente à metade do salário mínimo vigente em agosto de 2000 ) diminuiu $9,62 \%$, passando de $14,1 \%$ em 1991 para 12,8\% em 2000. O índice de Gini de Uberlândia demonstra um aumento na concentração de renda, sendo 0,53 em 1991 e passando a 0,56 em 2000. A classificação exposta acima, de 'regiões consideradas de alto desenvolvimento humano' confirma a análise da matriz aqui efetuada.
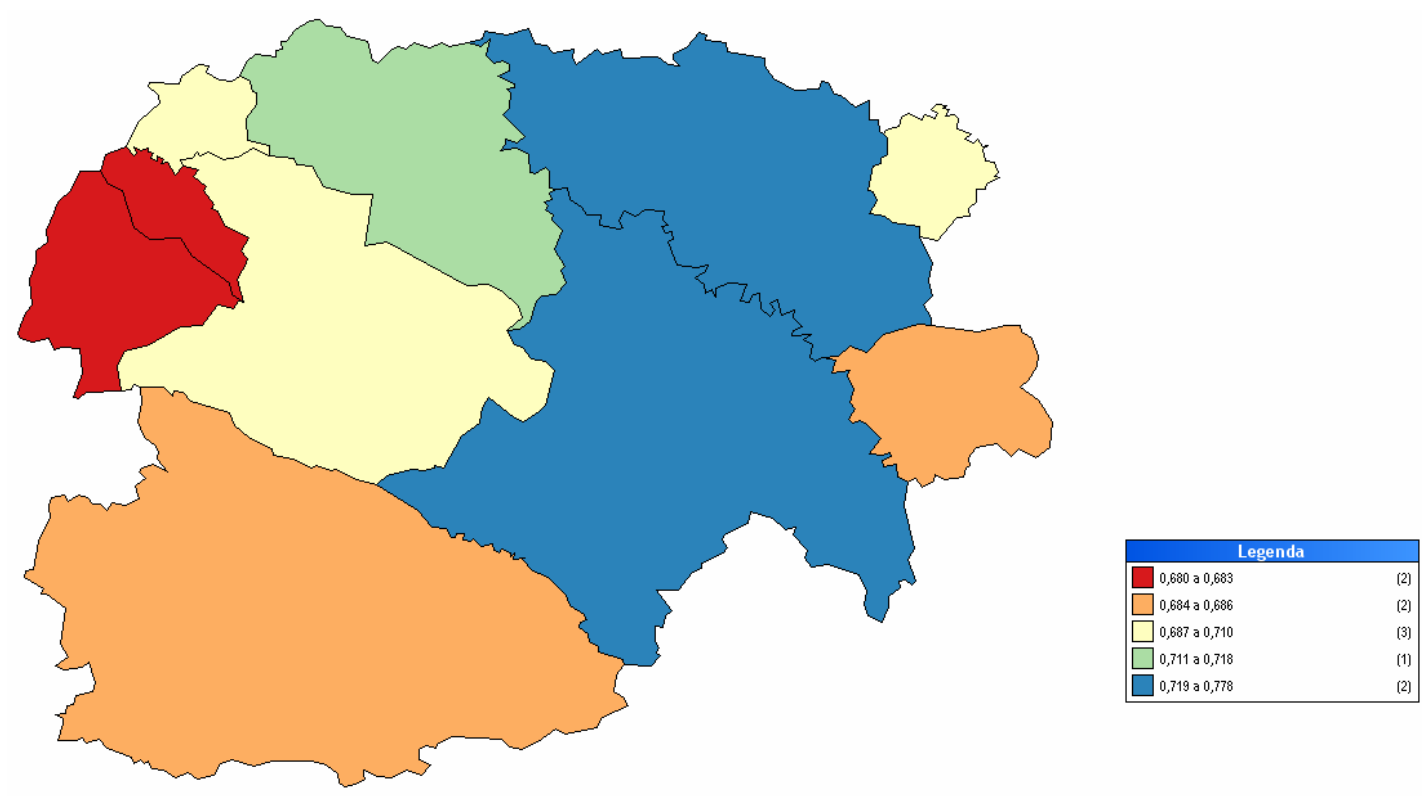

Mapa 25 - Índice de desenvolvimento humano dos municípios da microrregião de Uberlândia/MG, 1991.

FONTE: PNUD; IPEA; FJP, 2003. 

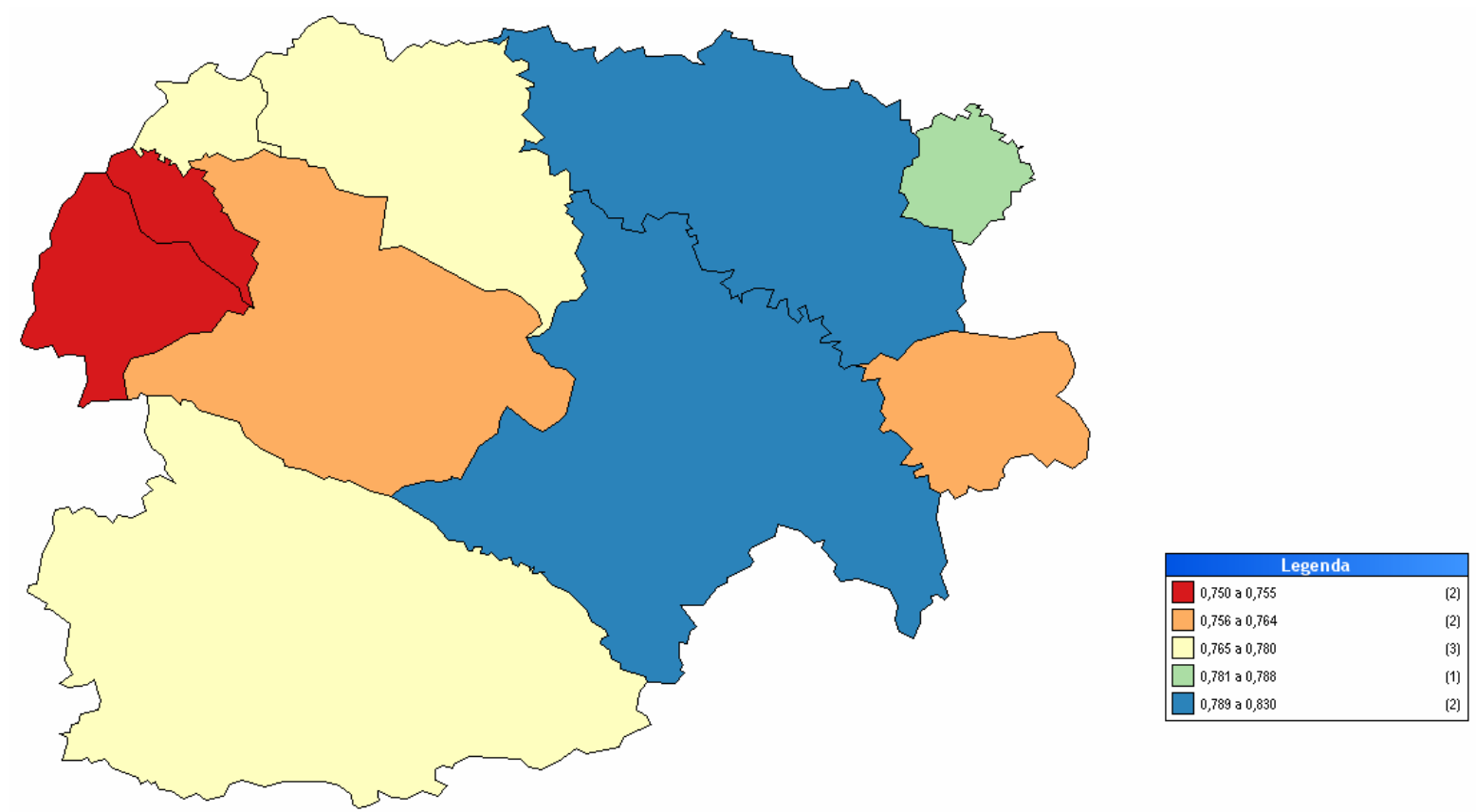

Mapa 26- Índice de desenvolvimento humano dos municípios da microrregião de Uberlândia/MG, 2000.

FONTE: PNUD; IPEA; FJP, 2003.

Os mapas 25 e 26 permitem ver a Microrregião e sua melhoria entre os anos de 1991 e 2000, tendo o município de Uberlândia ao meio em baixo, em cor azul.

\subsection{O APARATO URBANÍSTICO BRASILEIRO}

Nesta parte do texto, cabe uma contextualização do aparato legal brasileiro, no que esse refere ao ordenamento territorial urbano.

Conforme vai se apresentando no debate contemporâneo mundial sobre indicadores de 'sustentabilidade', a aplicação adequada do aparato legal existente é imprescindível para que ela se realize.

Algumas das legislações são pertinentes a esta análise, com destaque para as seguintes leis:

1. Constituição Federal do Brasil;

2. Lei n. 4.771 de 15 de novembro de 1965 - Código Florestal; 
3. Lei n. 6.766, de 19 de dezembro de 1979 - Lei de Parcelamento do solo urbano;

4. Lei n. 10.257, de 10 de junho de 2001 - Estatuto da Cidade.

No rebatimento das questões ambientais sobre o aparato legal brasileiro, a lei que primeiro deve ser vista é a Lei Federal de Parcelamento de Solo - Lei $n$ 6.766, de 19 de dezembro de 1979, alterada pela Lei n. 9.785, de 29 de janeiro de 1999.

Esta lei estabeleceu parâmetros mínimos que devem ser respeitados para o parcelamento do solo no Brasil. Sua aprovação foi contemporânea à eclosão da crise ambiental mundial e a questão urbana no país. A referida lei busca assegurar uma transformação na forma de ocupação do espaço.

Como parâmetros básicos definidores da qualidade ambiental, cabe citar aqueles que estão exatamente em acordo com o estabelecido pelo Habitat I e reafirmados na Agenda 21 e no Habitat II. Dentre estes itens estão: a definição da obrigatoriedade do empreendedor em implantar as estruturas de saneamento básico, água tratada e calçamento dos logradouros públicos, além de apresentar projeto com os perfis longitudinais e transversais das vias, demonstrando a devida adequação do traçado viário ao sítio de implantação.

Além disto, a Lei n. 6.766/79 determinava também a obrigatoriedade de destinação de trinta e cinco por cento da área total a áreas pública, que deveriam ser ocupadas pelos logradouros públicos, além dos equipamentos públicos de educação, cultura, saúde, lazer e similares (BRASIL, 1979). A obrigatoriedade de destinação de áreas públicas para a abertura de loteamentos foi um avanço em relação às leis anteriores de parcelamento do solo - Decreto-Lei n. 58, de 10 de dezembro de 1937, e Decreto-Lei n. 271, de 28 de fevereiro de 1967. 
A referida lei possui uma forte influência da Arquitetura Modernista, uma vez que propõe a constituição do espaço como estrutura praticamente independente do restante da cidade, formando as unidades de vizinhança comuns aos projetos da desta corrente de pensamento sobre o espaço.

A Lei n. 4.771, de 15 de novembro de 1965 - Código Florestal, também merece ser considerada nesta análise, uma vez que na ocupação do solo para fins urbanos são observadas algumas das suas referências, tais como: a possibilidade de ocupação de terrenos cuja declividade máxima de solo seja de 30\%; as áreas de preservação permanente ao longo das águas correntes e dormentes e das nascentes e das áreas de declividade superior a 45\%; além das áreas de topo de morro, restingas, dentre outras. Esta legislação contempla condicionantes que estão bastante afinados com as tendências ambientais do momento de sua elaboração. (BRASIL, 1965).

Já a Constituição Federal, promulgada em 1988, possui três capítulos de interesse:

- $\quad$ Dos Estados Federados, que no artigo 25, inciso 3, coloca:

$\S 3^{0}$ Os Estados poderão, mediante lei complementar, instituir regiões metropolitanas, aglomerações urbanas e microrregiões, constituídas por agrupamentos de municípios limítrofes, para integrar a organização, o planejamento e a execução de funções públicas de interesse comum. (BRASIL, 1988).

Faz-se importante registrar este inciso, pois no âmbito do planejamento urbano e regional, ele estabelece uma importante figura, a da região metropolitana como unidade de planejamento mais abrangente do que o município. Assim sendo, as questões ambientais que transpõe limites municipais podem ser geridas por uma esfera com poder decisório superior ao do município. Vis à vis serem as questões referentes aos pobres da cidade majoritariamente localizadas em áreas de sobreposição hierárquica entre os poderes federados, a institucionalização de 
regiões metropolitanas, desde que operacionalizadas através da constituição de assembléias supra-municipais, é de grande importância para a solução da generalidades dos problemas encontrados.

No caso específico de Minas Gerais, até os anos 90, muitos trabalhos foram desenvolvidos dentro do Governo do Estado de Minas Gerais, através da criação dentro da estrutura da FJP do Planejamento Metropolitano de Belo Horizonte (PLAMBEL), que dedicou-se a estudos e preposições da RMBH, que são bastante relevantes e utilizados até hoje, tanto no meio acadêmico para estudo de características de municípios quanto para tomadas de decisões territoriais e de planejamento regional. Em 2005, através da criação de uma Assembléia Metropolitana pelo governo estadual, surge uma nova tentativa de regulamentar a atuação desta estrutura.

Ainda tendo como referência a Constituição Federativa do Brasil:

- Da Política Urbana, com os artigos 182 e 183:

Art. 182. A política de desenvolvimento urbano, executada pelo Poder Público municipal, conforme diretrizes gerais fixadas em lei, tem por objetivo ordenar o pleno desenvolvimento das funções sociais da cidade e garantir o bem-estar de seus habitantes.

§ 1ㅇ- O plano diretor, aprovado pela Câmara Municipal, obrigatório para cidades com mais de vinte mil habitantes, é o instrumento básico da política de desenvolvimento e de expansão urbana.

$\S 2^{\circ}$ - A propriedade urbana cumpre sua função social quando atende às exigências fundamentais de ordenação da cidade expressas no plano diretor.

§ $3^{\circ}$ - As desapropriações de imóveis urbanos serão feitas com prévia e justa indenização em dinheiro.

§ 4ํ - É facultado ao Poder Público municipal, mediante lei específica para área incluída no plano diretor, exigir, nos termos da lei federal, do proprietário do solo urbano não edificado, subutilizado ou não utilizado, que promova seu adequado aproveitamento, sob pena, sucessivamente, de:

I - parcelamento ou edificação compulsórios;

II - imposto sobre a propriedade predial e territorial urbana progressivo no tempo;

III - desapropriação com pagamento mediante títulos da dívida pública de emissão previamente aprovada pelo Senado Federal, com 
prazo de resgate de até dez anos, em parcelas anuais, iguais e sucessivas, assegurados o valor real da indenização e os juros legais.

Art. 183. Aquele que possuir como sua área urbana de até duzentos e cinqüenta metros quadrados, por cinco anos, ininterruptamente e sem oposição, utilizando-a para sua moradia ou de sua família, adquirir-Ihe-á o domínio, desde que não seja proprietário de outro imóvel urbano ou rural.

$\S 1^{\circ}$ - O título de domínio e a concessão de uso serão conferidos ao homem ou à mulher, ou a ambos, independentemente do estado civil.

$\S 2^{\circ}$ - Esse direito não será reconhecido ao mesmo possuidor mais de uma vez.

§ $3^{\circ}$ - Os imóveis públicos não serão adquiridos por usucapião. (BRASIL, 1988).

O artigo 182 dá a dimensão de serem os brasileiros 'sujeitos de direito internacional - cidadãos internacionais e não apenas nacionais', conforme já citado em Saule (2001), afirmando que o poder público municipal deve ordenar o desenvolvimento das funções sociais através da adoção do planejamento urbano.

O capítulo Política Urbana inicia uma discussão que só seria regulamentado com a Lei n. 10.257/01 - Estatuto da Cidade. De qualquer forma, este capítulo propõe o uso compulsório do solo, visando adequação da propriedade da terra à função social.

O Estatuto da Cidade regulamenta os artigos 182 e 183 da Constituição Federal do Brasil. Estes artigos fazem parte do Capítulo da Política Urbana, designando normas para o funcionamento das cidades, como a obrigatoriedade do Plano Diretor para cidades com mais de 20 mil habitantes; reafirmando noção da função social da propriedade como definidora da ocupação territorial, entre outros.

O Estatuto da Cidade cria instrumentos que possibilitam que a propriedade e a cidade cumpram seu papel social. Cabe aqui, então, uma discussão sobre o que vem a ser este papel social da propriedade. 
Amaral (1996) coloca que a propriedade cumpre seu papel social quando as atividades que nela desenvolvem-se ocorrem sem prejuízo umas das outras. Isto define que a propriedade tem determinados usos que são compatíveis com outros usos, ao mesmo tempo em que existem usos que não podem conviver harmoniosamente. Caso claro, seria a proximidade de um conjunto residencial de uma área que emita poluentes sonoros ou resíduos tóxicos na água ou no solo. Então, a função social estaria sendo direcionada e articulada por um planejamento do uso do solo urbano, atribuição esta do Plano Diretor Municipal. Nos dizeres da própria Constituição: 'a propriedade cumpre seu papel social quando exerce as funções estabelecidas no Plano Diretor' (BRASIL, 1988).

Outra interpretação de função social da propriedade é aquela que define os instrumentos do Estatuto da Cidade. É a visão da reforma urbana, ou seja, de possibilitar o acesso à propriedade urbana a um maior número de pessoas. Para que este acesso seja possível, alguns instrumentos foram criados visando agir contra a concentração fundiária urbana.

O terceiro ponto ressaltado na Constituição Federal:

- $\quad$ Do meio ambiente, com o artigo 225:

Art. 225. Todos têm direito ao meio ambiente ecologicamente equilibrado, bem de uso comum do povo e essencial à sadia qualidade de vida, impondo-se ao Poder Público e à coletividade o dever de defendê-lo e preservá-lo para as presentes e futuras gerações.

$\S 1$ - Para assegurar a efetividade desse direito, incumbe ao Poder Público: ${ }^{40}$

IV - exigir, na forma da lei, para instalação de obra ou atividade potencialmente causadora de significativa degradação do meio ambiente, estudo prévio de impacto ambiental, a que se dará publicidade;

V - controlar a produção, a comercialização e o emprego de técnicas, métodos e substâncias que comportem risco para a vida, a qualidade de vida e o meio ambiente; [...].

${ }^{40}$ Os demais incisos foram suprimidos nesta análise, por serem referentes principalmente ao manejo dos recursos ambientais. 
O Capítulo sobre Meio Ambiente reitera a necessidade dos Estudos de Impacto do Meio Ambiente (EIA) e dos Relatórios de Impacto do Meio Ambiente (RIMA), criados pela Lei n. 6.938 , de 31 de agosto de 1981 , que dispõe sobre a Política Nacional do Meio Ambiente.

Coloca também o Meio Ambiente como um 'bem de direito difuso' (FÜHRER; ÉDIS, 2003), por estabelecer, em coerência com o Relatório Brudtland (1986), que 'todos tem direito ao meio ambiente sadio (...) e o dever de defendê-lo e preservá-lo para as presentes e futuras gerações'.

A Lei n. 10.257, de 10 de julho de 2001 - Estatuto da Cidade - Política Urbana, procura regulamentar os artigos 182 e 183 da Constituição Federal, conforme disposto anteriormente. Os principais instrumentos enfocados no Estatuto da Cidade são aqueles que procuram dar diretrizes para a implementação da função social da propriedade pelos governos locais. O Estatuto define parâmetros para que o desenvolvimento das cidades possa ocorrer de forma ordenada, equilibrada, sustentável; garantindo a gestão democrática do espaço; dando utilização adequada aos imóveis urbanos; combatendo a retenção especulativa do solo; integrando e aproximando usos compatíveis de solo; recuperando os investimentos feitos pelo poder público, protegendo o patrimônio urbano; regularizando a questão fundiária das áreas de interesse social entre outras preocupações e providências a serem tomadas (BRASIL, 2001).

O Plano Diretor municipal é ressaltado como o principal instrumento de desenvolvimento urbano, devendo estarem contidos nele os principais instrumentos do Estatuto da Cidade. São descritos, a seguir, alguns destes instrumentos e comentadas as expectativas de sua ação.

1. Instrumentos de combate à retenção especulativa de terras na cidade, para melhorar a oferta de lotes e reduzir o preço dos imóveis. 
a. Parcelamento, edificação ou utilização compulsórios:

Mediante notificação do poder público municipal, poderá ser parcelado, edificado ou utilizado imóvel que esteja ocioso à espera de valorização especulativa. Este instrumento e os demais deste grupo combatem a retenção de terras com o objetivo de que a cidade não seja dispendiosa aos cofres públicos; ao mesmo tempo que possibilite o acesso à moradia da população e sem se estender à proporções gigantescas ocasionadas pelos vazios urbanos, de caráter especulativo.

b. Imposto predial e territorial urbano progressivo no tempo:

Este instrumento ocorre no mesmo sentido do anterior, visando a forçar a utilização do imóvel ocioso. Quanto mais o tempo perdurar a retenção acumulativa, mais caro ficará o imposto sobre o bem.

c. Desapropriação com pagamento de títulos:

O imóvel que não cumprir as determinações previamente estabelecidas poderá ser desapropriado com o pagamento feito em títulos da dívida pública, resgatados no prazo de até dez anos.

d. Direito de superfície:

O proprietário, sem perder a propriedade, poderá conceder a outra pessoa, por tempo determinado ou indeterminado, o direito de utilizar o solo.

e. Direito de preempção:

O Município terá preferência na compra do imóvel urbano situado em área previamente delimitada por lei municipal - Plano Diretor, assegurado o valor de mercado, desde que a aquisição do imóvel pelo poder público atenda a finalidade estabelecida por lei.

Este instrumento deve ser usado principalmente para corrigir desequilíbrios na malha urbana, como a falta de moradias ou de equipamentos urbanos para sua população. 
2. Instrumentos para melhorar a distribuição dos benefícios e dos ônus do processo de urbanização

a. $\quad$ Outorga onerosa do direito de construir (solo criado):

O Estatuto sugere a criação de um coeficiente de aproveitamento básico para toda a área urbana do município. A lei municipal permitirá o aumento do potencial construtivo em áreas determinadas por lei municipal, mediante pagamento do empreendedor por esta área adicional. Este instrumento visa acabar com a supervalorização de determinadas áreas na cidade, que possuem um coeficiente superior ao de outras áreas.

b. Operações urbanas consorciadas:

São um conjunto de intervenções coordenadas pelo Município com a participação dos proprietários, moradores, usuários e investidores privados, operando uma transformação urbanística em uma determinada área da cidade, para atingir melhorias sociais e valorização ambiental.

c. Transferência do direito de construir:

O proprietário de um imóvel considerado de importância social, como os imóveis tombados, poderá construir em outro local ou alienar para outra pessoa o potencial construtivo ai existente.

Este instrumento tenta dar uma solução ao impasse histórico que ocorre entre propriedade e patrimônio no Brasil. O interesse coletivo fica protegido, enquanto é resguardado o direito de propriedade.

\section{d. Estudo de impacto de vizinhança:}

Este é, seguramente, um dos mais importantes instrumentos estabelecidos, no sentido de garantir a participação da comunidade na gestão do espaço público. Através de sua adoção, todos os empreendimentos, públicos ou privados, devem ser discutidos quanto ao impacto causado sobre a vizinhança antes de sua aprovação. 
Visa garantir a qualidade do ambiente urbano, através da manutenção da ventilação, iluminação natural, bem como interferência na paisagem urbana e no patrimônio cultural e ambiental.

3. Instrumentos de regularização fundiária e urbanização de áreas ocupadas por população de baixa renda

a. Usucapião especial de imóveis urbanos:

Será concedido ao homem ou a mulher, para sua moradia ou de sua família, o título de domínio de imóvel até $250 \mathrm{~m}^{2}$, ocupado, sem oposição do proprietário, há mais de cinco anos. O beneficiário desse direito não poderá possuir nenhum outro imóvel urbano ou rural.

\section{b. Usucapião especial coletivo:}

Em áreas superiores a $250 \mathrm{~m}^{2}$, nas quais não seja possível identificar os terrenos ocupados por possuidor, poderá ser proposta ação de usucapião coletiva, pelos interessados ou pela associação de moradores legalmente constituída e autorizada pelos representados, sendo obrigatória, nesse caso, a intervenção do Ministério Público no processo.

Estes são alguns dos principais instrumentos abordados pelo Estatuto. Sua aplicação visa a trazer soluções às conhecidas características de ocupação do espaço urbano brasileiro.

O Estatuto da Cidade encontra-se em total coerência com a Agenda Habitat e com a Agenda 21, definindo formas de ação para que sejam minimizadas as questões relativas à grande concentração fundiária existente no país, que seria uma das causas do desequilíbrio ambiental brasileiro, ao constituir cidades que se espraiam indefinidamente, além de dispor claramente contra a segregação social, amplamente difundida em todos os textos das conferências. 
Portanto, a discussão da 'sustentabilidade' do ambiente urbano pode até ser inócua, tal como a crítica ao arcabouço de leis urbanísticas do Brasil, tendo em vista que são múltiplas as variáveis que devam ser consideradas do que venha a ser sustentável e que não será possível chegar-se então a termo. Que pese a distância entre as políticas públicas, os planos de governo, as cartas de intenção e a gestão do espaço. Não há como, no entanto, negligenciar que existam alguns avanços no sentido da construção de uma relação mais equilibrada na construção do ambiente como um todo e do ambiente urbano especificamente.

A aprovação da Lei n. 10.257/01 é uma comprovação disto, sendo considerado por alguns como sendo uma herança do trabalho iniciados pela CNPU, posterior, CNDU. Tenta equalizar acesso à moradia, equipamento, infra-estrutura à população geral da cidade, pela evidência do uso social da propriedade, e as classes baixas, especificamente, pela criação de diversos instrumentos que potencializam a criação de Zonas Especiais de Interesse Social (ZEIS).

Os indicadores propostos pela $\mathrm{UN}$-Habitat dentro Agenda Habitat parecem ser bem claros quanto à necessidade de adoção dos instrumentos aqui apresentados.

Assim sendo, o aparato legal permite que ocorra a necessária 'reforma urbana', muito mais contemporânea aos anseios e vicissitudes da população brasileira.

\subsection{CONSIDERAÇÕES FINAIS}

Considerando as cinco cidades escolhidas para análise como representantes de distintas regiões do estado de Minas Gerais, tem-se a análise de 
algumas das principais cidades médias mineiras, cidades-pólos das regiões em que se localizam.

Para estabelecer as prioridades de suas ações, o PROECI agrupou da seguinte forma as cinco cidades analisadas, segundo a predominância de atividades que deveriam ocorrer nas mesmas:

- Governador Valadares e Montes Claros = geração de emprego e melhoria da qualidade de vida para baixa renda;

- Uberlândia = atividades agro-industriais, armazenamento e comercialização, integração centro-sul - centro-oeste;

- Juiz de Fora, Poços de Caldas = crescimento da produção industrial e aumento da oferta de bens de consumo coletivo para baixa renda.

Analisando as matrizes das Matrizes de Indicadores de Qualidade de Vida Urbanas - Composição Tonal pela semelhança do comportamento dos indicadores presentes nos municípios, como na página ao lado, chega-se à mesma divisão de grupos apresentada pelo PROECI.

Assim sendo, pode-se perceber que Governador Valadares e Montes Claros, além da similaridade de serem cidades que captam os migrantes do nordeste do país indo para outras direções, de serem áreas hostis à de penetração quando da sua ocupação, partem de um horizonte de qualidade ambiental quase idêntico. Valadares tem o abastecimento e a coleta de água com índices imediatamente superiores aos de Montes Claros, porém, seu número de indicadores com valoração tonal 'baixa a média qualidade de ambiente urbano' é maior do que o número presente na matriz de Montes Claros. 
Quadro 27 - Matriz de Indicadores de Qualidade de Vida Urbana - Governador Valadares - Composição tonal

\begin{tabular}{|c|c|}
\hline Grupo & Indicadores \\
\hline 1. Abastecimento domiciliar de água & Acesso à água potável \\
\hline \multirow{2}{*}{ 2. Saneamento básico } & Coleta de água servida \\
\hline & Recolhimento regular de dejetos sólidos \\
\hline \multirow{4}{*}{ 3. Habitação } & Percentual de população acima do limiar da pobreza \\
\hline & \begin{tabular}{|l|l} 
Proporção de domicilios com menos de três pessoas por cômodo \\
\end{tabular} \\
\hline & Utilização materiais permanentes que propiciem uma habitação segura e duradoura \\
\hline & Conexões hidro-sanitárias internas ao domicílio \\
\hline
\end{tabular}

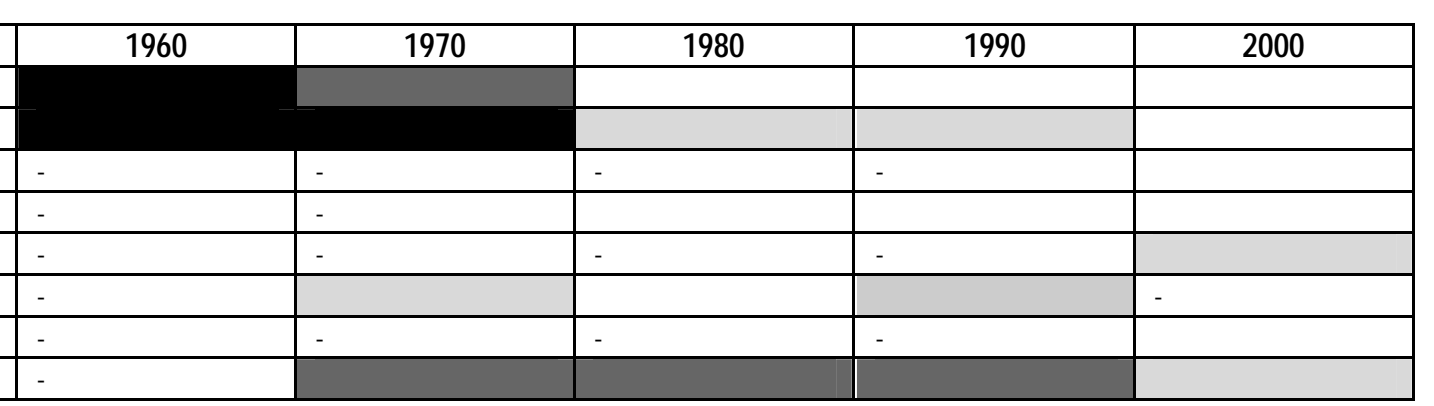

Quadro 28 - Matriz de Indicadores de Qualidade de Vida Urbana - Juiz de Fora - Composição tonal

\begin{tabular}{|c|c|}
\hline Grupo & Indicadores \\
\hline 1. Abastecimento domiciliar de água & Acesso à água potável \\
\hline \multirow{2}{*}{ 2. Saneamento básico } & Coleta de água servida \\
\hline & Recolhimento regular de dejetos sólidos \\
\hline \multirow{4}{*}{ 3. Habitação } & Percentual de população acima do limiar da pobreza \\
\hline & Proporção de domicílios com menos de três pessoas por cômodo \\
\hline & Utilização materiais permanentes que propiciem uma habitação segura e duradoura \\
\hline & Conexões hidro-sanitárias internas ao domicílio \\
\hline
\end{tabular}

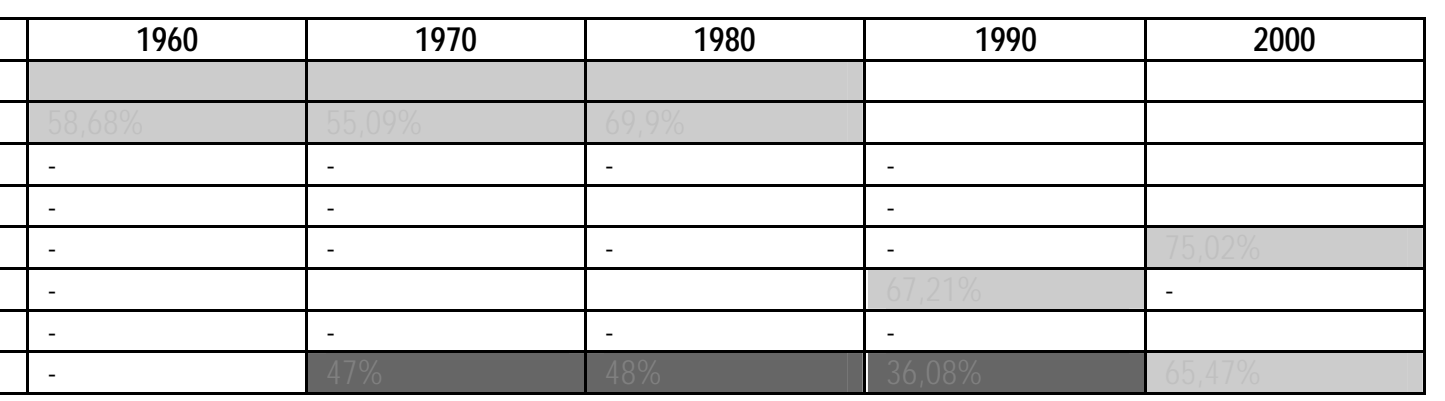

Quadro 29 - Matriz de Indicadores de Qualidade de Vida Urbana - Montes Claros - Composição tonal

\begin{tabular}{|c|c|c|c|c|c|c|c|}
\hline Grupo & & Indicadores & 1960 & 1970 & 1980 & 1990 & 2000 \\
\hline 1. Abastecimento domiciliar de água & Acesso à ác & & & & $51,45 \%$ & & \\
\hline \multirow{2}{*}{ 2. Saneamento básico } & \multicolumn{2}{|c|}{ Coleta de água servida } & & & & & \\
\hline & \multicolumn{2}{|c|}{ Recolhimento regular de dejetos sólidos } & & - & - & - & \\
\hline \multirow{5}{*}{ 3. Habitação } & \multicolumn{2}{|c|}{$\begin{array}{l}\text { Percentual de população acima do limiar da pobreza } \\
\text { Dencidado }\end{array}$} & - & - & & - & \\
\hline & Densidade & Proporção de domicílios com menos de três pessoas por cômodo & - & - & - & - & \\
\hline & \multirow{3}{*}{$\begin{array}{l}\text { Benfeitoria } \\
\text { Posse }\end{array}$} & Utilização materiais permanentes que propiciem uma habitação segura e duradoura & - & & & & \\
\hline & & Conexões hidro-sanitárias internas ao domicílio & & - & - & & \\
\hline & & Habitação cuja ocupação esteja assegurada & & & & & \\
\hline
\end{tabular}

Quadro 30 - Matriz de Indicadores de Qualidade de Vida Urbana - Poços de Caldas - Composição tonal

\begin{tabular}{|c|c|c|c|c|c|c|}
\hline Grupo & Indicadores & 1960 & 1970 & 1980 & 1990 & 2000 \\
\hline 1. Abastecimento domiciliar de água & \multirow{2}{*}{$\begin{array}{l}\text { Acesso à água potável } \\
\text { Coleta de água servida }\end{array}$} & & & & & \\
\hline \multirow{2}{*}{ 2. Saneamento básico } & & & & & & \\
\hline & Recolhimento regular de dejetos sólidos & & - & & - & \\
\hline \multirow{5}{*}{ 3. Habitação } & Percentual de população acima do limiar da pobreza & - & - & & - & \\
\hline & \begin{tabular}{l|l} 
& Proporção de domicílios com menos de três pessoas por cômodo \\
\end{tabular} & - & - & & - & \\
\hline & Utilização materiais permanentes que propiciem uma habitação segura e duradoura & - & & & & - \\
\hline & Conexões hidro-sanitárias internas ao domicílio & & & & & \\
\hline & Habitação cuja ocupação esteja assegurada & - & & & & \\
\hline
\end{tabular}

Quadro 31 - Matriz de Indicadores de Qualidade de Vida Urbana - Uberlândia - Composição tonal

\begin{tabular}{|c|c|c|}
\hline Grupo & & Indicadores \\
\hline 1. Abastecimento domiciliar de água & \multicolumn{2}{|c|}{ Acesso à água potável } \\
\hline \multirow{2}{*}{ 2. Saneamento básico } & \multicolumn{2}{|c|}{ Coleta de água servida } \\
\hline & \multirow{2}{*}{\multicolumn{2}{|c|}{$\begin{array}{l}\text { Recolhimento regular de dejetos sólidos } \\
\text { Percentual de ponulacão acima do limiar da nobreza }\end{array}$}} \\
\hline \multirow{5}{*}{ 3. Habitação } & & ão acima do limiar da pobreza \\
\hline & & Proporção de domicilios com menos de três pessoas por cômodo \\
\hline & \multirow[t]{2}{*}{ Benfeitoria } & Utilização materiais permanentes que propiciem uma habitação segura e duradoura \\
\hline & & Conexões hidro-sanitárias internas ao domicílio \\
\hline & Posse & Habitação cuja ocupação esteja assegurada \\
\hline
\end{tabular}

\begin{tabular}{|c|c|c|c|c|}
\hline 1960 & 1970 & 1980 & 1990 & 2000 \\
\hline & & & & \\
\hline- & - & - & - & \\
\hline & - & & - & \\
\hline- & - & - & - & \\
\hline & & & & \\
\hline & - & & & \\
\hline
\end{tabular}


Quadro 32 - Matriz de Indicadores de Qualidade de Vida Urbana - Governador Valadares - Composição tonal

\begin{tabular}{|c|c|}
\hline Grupo & Indicadores \\
\hline 1. Abastecimento domiciliar de água & Acesso à água potável \\
\hline \multirow{2}{*}{ 2. Saneamento básico } & \multirow{2}{*}{$\begin{array}{l}\text { Coleta de água servida } \\
\text { Recolhimento regular de dejetos sólidos }\end{array}$} \\
\hline & \\
\hline \multirow{5}{*}{ 3. Habitação } & Percentual de população acima do limiar da pobreza \\
\hline & Proporção de domicílios com menos de três pessoas por cômodo \\
\hline & Utilização materiais permanentes que propiciem uma habitação segura e duradoura \\
\hline & Conexões hidro-sanitárias internas ao domicílio \\
\hline & Habitação cuja ocupação esteja assegurada \\
\hline
\end{tabular}

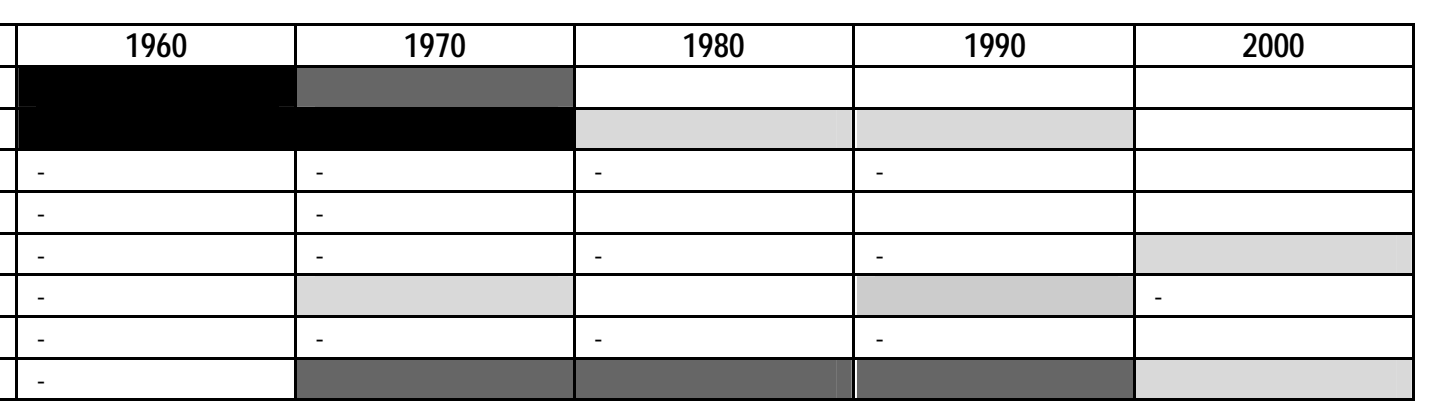

Quadro 33 - Matriz de Indicadores de Qualidade de Vida Urbana - Montes Claros - Composição tonal

\begin{tabular}{|c|c|c|}
\hline Grupo & & Indicadores \\
\hline 1. Abastecimento domiciliar de água & \multicolumn{2}{|c|}{ Acesso à água potável } \\
\hline \multirow{2}{*}{ 2. Saneamento básico } & \multicolumn{2}{|c|}{ Coleta de água servida } \\
\hline & \multicolumn{2}{|c|}{ Recolhimento regular de dejetos sólidos } \\
\hline \multirow{4}{*}{ 3. Habitação } & \multicolumn{2}{|c|}{ Percentual de população acima do limiar da pobreza } \\
\hline & Densidade & Proporção de domicílios com menos de três pessoas por cômodo \\
\hline & \multirow{2}{*}{ Benfeitoria } & Utilização materiais permanentes que propiciem uma habitação segura e duradoura \\
\hline & & Conexões hidro-sanitárias internas ao domićlío \\
\hline
\end{tabular}

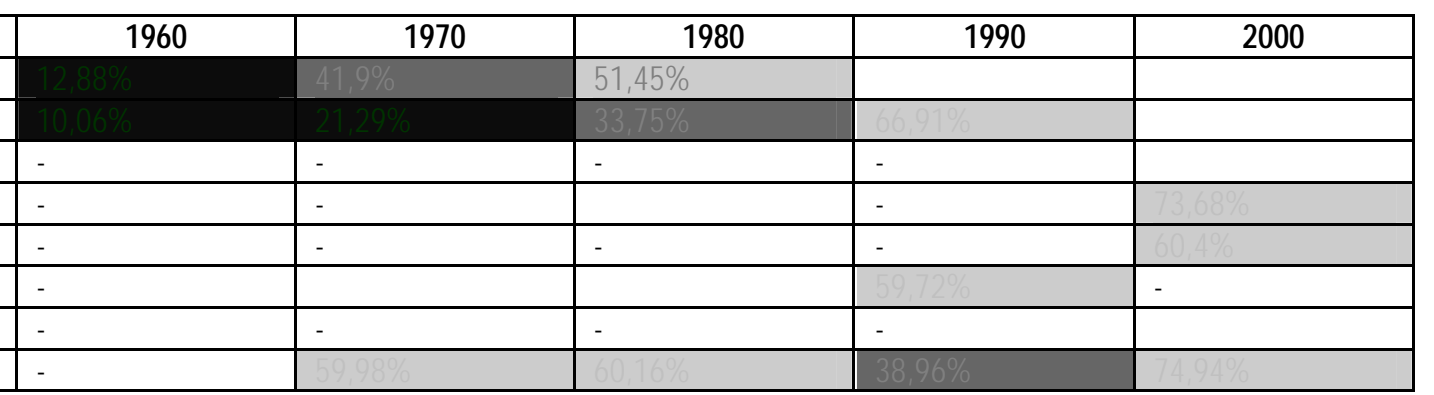

Quadro 34 - Matriz de Indicadores de Qualidade de Vida Urbana - Uberlândia - Composição tonal

\begin{tabular}{|c|c|}
\hline Grupo & Indicadores \\
\hline 1. Abastecimento domiciliar de água & Acesso à água potável \\
\hline \multirow{2}{*}{ 2. Saneamento básico } & Coleta de água servida \\
\hline & Recolhimento regular de dejetos sólidos \\
\hline \multirow{5}{*}{ 3. Habitação } & Percentual de população acima do limiar da pobreza \\
\hline & Proporção de domićilios com menos de três pessoas por cômodo \\
\hline & Utilização materiais permanentes que propiciem uma habitação segura e duradoura \\
\hline & Conexões hidro-sanitárias internas ao domicílio \\
\hline & Habitação cuja ocupação esteja assegurada \\
\hline
\end{tabular}

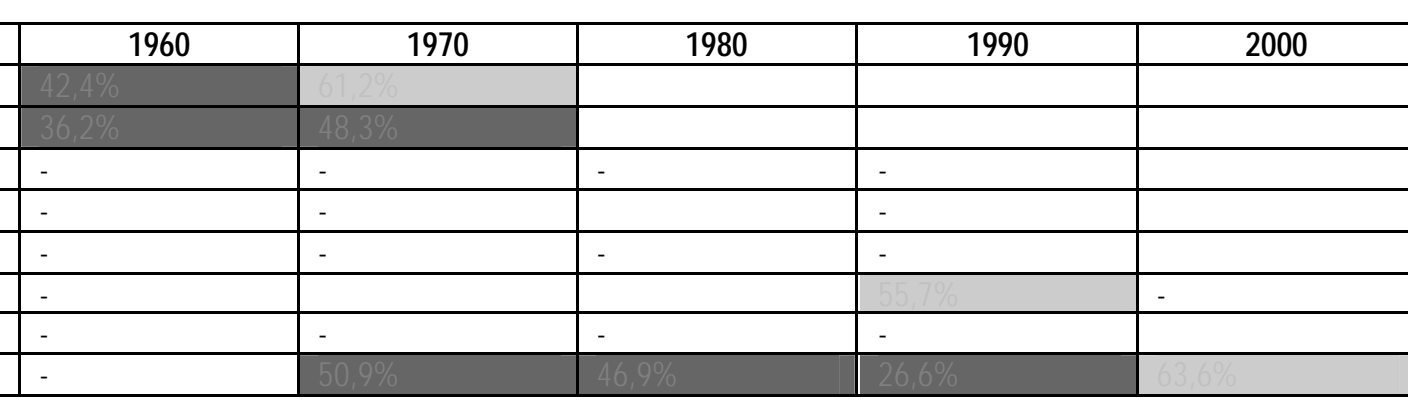

Quadro 35 - Matriz de Indicadores de Qualidade de Vida Urbana - Poços de Caldas Composição tonal

\begin{tabular}{|c|c|}
\hline Grupo & Indicadores \\
\hline 1. Abastecimento domiciliar de água & Acesso à água potável \\
\hline \multirow{2}{*}{ 2. Saneamento básico } & Coleta de água servida \\
\hline & $\begin{array}{l}\text { Colela de agua servica } \\
\text { Recolhimento reqular de dejetos sólidos }\end{array}$ \\
\hline \multirow{4}{*}{ 3. Habitação } & Percentual de população acima do limiar da pobreza \\
\hline & Proporção de domicílios com menos de rês pessoas por cômodo \\
\hline & Utilização materiais permanentes que propiciem uma habitação segura e duradoura \\
\hline & Conexões hidro-sanitárias internas ao domicílio \\
\hline
\end{tabular}

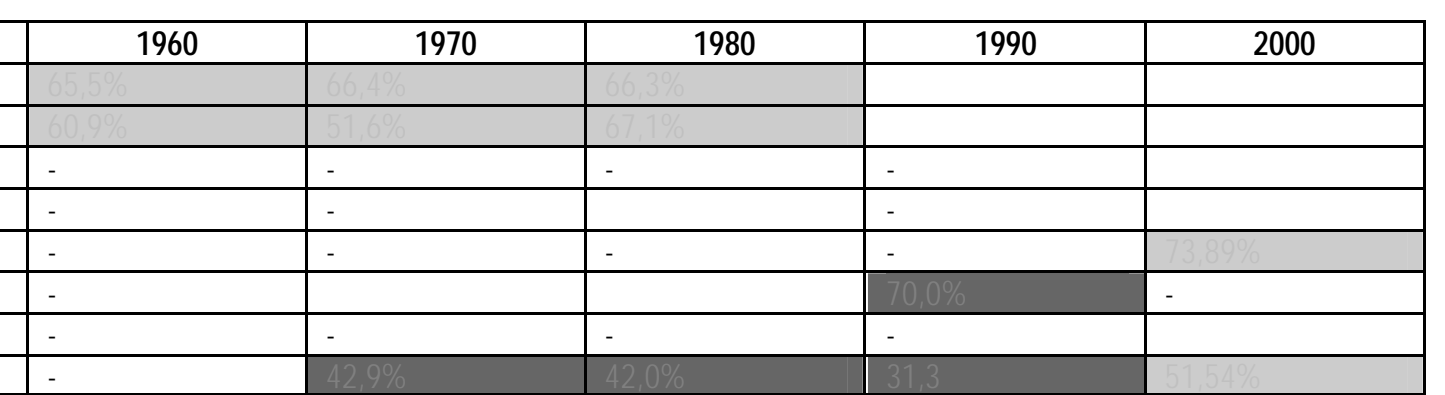

Quadro 36 - Matriz de Indicadores de Qualidade de Vida Urbana - Juiz de Fora - Composição tonal

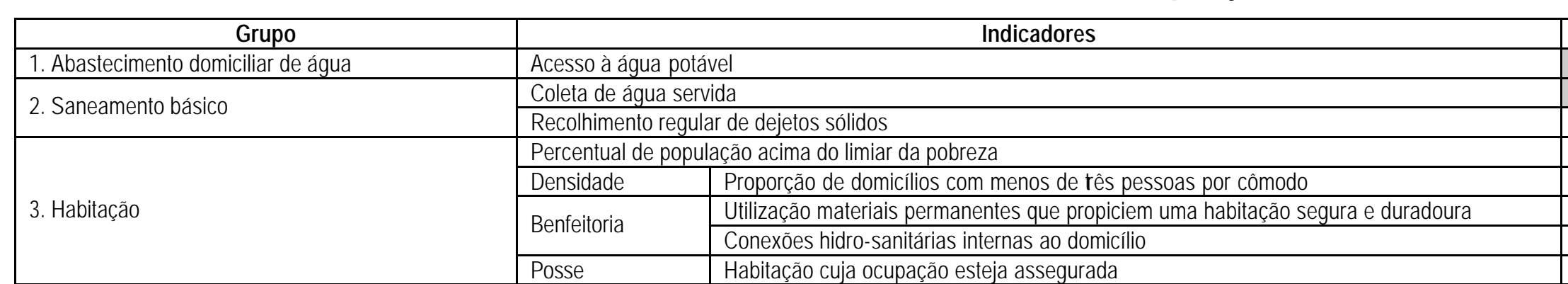

\begin{tabular}{|l|l|l|l|l|l|}
\hline 1960 & \multicolumn{1}{|c|}{1970} & \multicolumn{1}{c|}{1980} & \multicolumn{1}{c|}{1990} & 2000 \\
\hline & & & & \\
\hline- & - & & & \\
\hline- & - & - & - & \\
\hline- & - & & - & \\
\hline- & - & - & - & \\
\hline- & - & - & - & - \\
\hline
\end{tabular}


Já as cidades de Juiz de Fora e Poços de Caldas possuem também matrizes muito semelhantes. Partem de um horizonte em que a qualidade de vida era melhor do que as demais cidades, possuem uma base industrial resultante do transbordamento das atividades de Rio e São Paulo e não possuem nenhum indicador tonal classificado como 'baixa qualidade de vida urbana'.

Cabe salientar que para a classificação do IDH-Municipal (PNUD; IPEA; FJP), Poços de Caldas é a primeira cidade do estado de Minas Gerais, sendo considerada de 'alto padrão de desenvolvimento humano'. Também Juiz de Fora tem a mesma classificação, mas na comparação das duas matrizes, a segunda cidade tem um índice que a coloca em vantagem sobre a primeira, sendo este a valoração dada para 'Utilização de materiais permanentes que propiciem uma habitação segura e duradoura' para a década de 1990, em que a valoração para Poços de Caldas é 'baixa a média qualidade de vida urbana' e a valoração para Juiz de Fora é de 'média a alta qualidade de ambiente urbano' para o mesmo item.

Como este trabalho não pretende construir nenhum ranking entre as cidades, a observação demonstra apenas que a qualificação de um município segundo índices evidenciará características adotadas para a construção do mesmo.

Uberlândia comporta-se à parte, partindo de um horizonte inicial de características distintas aos outros dois agrupamentos, atinge níveis mais altos melhora sua condição ambiental antes do Juiz de Fora e Poços de Caldas, ou seja, a partir da década de 1980 seus índices superam o daquelas duas cidades.

Considerando que o diferencial na qualidade do ambiente no município de Juiz de Fora estabelecido pela matriz está em período anterior e posterior às políticas públicas aqui analisadas, pode-se referenciar que elas forma pouco motivadoras da qualidade do ambiente. 
Ressalta-se ainda, que o PROECI não atuou no município, o que pode ser considerado também como um fator relevante para que os dados intermediários não tenham sido tão ampliados em relação aos iniciais, como se deu em Governador Valares.

Com relação a atuação das políticas públicas na constituição de um ambiente sustentável, percebe-se que a atuação sobre Governador Valadares e Montes Claros é mais nítida no período das intervenções estatais. Pode-se considerar que para o horizonte que possuíam existiu uma efetiva melhora concentrada no período entre os anos 1970 e 1990, que é contemporâneo às atividades dos programas Nacionais de Capitais e Cidades de Porte Médio, de Cidades de Porte Médio e de Centros Intermediários.

Juiz de Fora e Poços de Caldas não obtiveram recursos do PROECl e estão entre as três cidades de melhores índices dentre as analisadas. Foram também as cidades que sofreram menor alteração da qualidade do ambiente urbano no período de investimento das políticas públicas.

Fazendo uma classificação para as cinco cidades, os agrupamentos permanecem os mesmos daquele anteriormente exposto. Governador Valadares e Montes Claros possuem uma classificação de 'baixa a média qualidade do ambiente urbano' se considerada toda sua série histórica. Se observado o ano de 2000, podese classificá-la como uma cidade de 'média qualidade de ambiente urbano', pois neste período, seus índices apresentam-se na maioria entre ‘adequada qualidade de ambiente urbano'. Mas como o histórico tem passivos ambientais, a classificação adotada de ‘média qualidade de ambiente urbano' seria mais pertinente.

Juiz de Fora e Poços de Caldas poderiam ser classificadas de 'média a adequada qualidade de vida urbana' em toda sua série histórica. Considerando os 
dados para o ano de 2000, elas seriam cidades de 'adequada qualidade ambiental urbana'.

Uberlândia partiria de uma análise um pouco melhor que o primeiro grupo, formado por Governador Valadares e Montes Claros e um pouco pior que o segundo grupo, formado por Juiz de Fora e Poços de Caldas. Poderia ser classificada sua série histórica poderia figurar como 'média qualidade de vida urbana', simplesmente. Mas sua qualidade de vida a partir dos anos 1980 se assemelha ao grupo de Juiz de Fora e Poços de Caldas, superando-o a partir dos anos 1990. Cabe evidenciar que a qualidade de vida de Uberlândia é a melhor para o ano de 2000, entre as cinco cidades analisadas. Assim sendo, sua classificação também fica como 'adequada qualidade de vida urbana', se for considerado o horizonte do ano de $2000 \mathrm{com}$ referência.

Fato que demonstra a 'insustentabilidade' urbana é a ausência de formas de tratamento para o esgoto coletado. Em nenhuma das cidades analisadas possuem Estação de Tratamento de Esgotos (ETE) em funcionamento. Também a disposição final do lixo está em aberto para todos os municípios, mesmo quando existe aterro sanitário.

Como foi salientado para a análise de cada qual das matrizes dos municípios, o fato de terem sido obtido apenas 21 dados dos 140 que foram propostos para a matriz total, não seria a garantia da caracterização de 'sustentabilidade' frente à matriz estudada.

O apresentado aqui acerca das cidades analisadas, mesmo que não sendo possível de ser transformado em índices e percentuais a serem utilizados como dados da matriz, apontam para outros critérios que modificam as classificações das cidades. Isto pode ser constatado pela leitura dos textos dos Planos Diretores municipais que, sem exceção, apontam para uma alta extensão dos loteamentos 
com baixa ocupação efetiva das áreas parceladas. Isto indica concentração fundiária e evidencia para a ausência de outros níveis de sustentabilidade urbana, pois todas as cidades apresentam quadros de déficit habitacional. Ora, se existe uma oferta excessiva de terra que não consegue ser absorvida - e mesmo assim, mantém o preço da terra elevado - caracteriza-se a figura do cartel ou especulação imobiliária feita por um pequeno grupo de pessoas, que conseguem juntas estabelecer 0 rendimento da terra.

As cidades perdem, assim, a possibilidade de a serem sustentáveis em relação ao indicador de proximidade casa-trabalho, 'habitação cuja posse esteja assegurada', 'preço de habitação e coeficiente de habitações ingressadas no montante final', por exemplo.

Assim sendo, Poços de Calda apresenta o Índice de Gini o mais baixo dentre os municípios analisados. Entretanto, sua relação para o indicador 'habitação cuja posse esteja assegurada' é o menor dentre todos os municípios, sendo $51 \%$ do total. Interessante ressaltar que Montes Claros, sendo a segunda pior realidade analisada, tem o melhor índice para este indicador, sendo $73 \%$ o número de habitações cuja posse está assegurada no município.

\section{Quadro 37 - Índice de Gini}

\begin{tabular}{|l|r|}
\hline Brasil & 0,6366 \\
\hline Minas Gerais & 0,6347 \\
\hline Governador Valadares & 0,62 \\
\hline Juiz de Fora & 0,58 \\
\hline Montes Claros & 0,62 \\
\hline Poços de Caldas & 0,56 \\
\hline Uberlândia & 0,56 \\
\hline FONTE: IBGE. & \\
\hline
\end{tabular}

Cabe sempre reafirmar que muitos índices não forma adotados na Matriz de Qualidade de Ambiente Urbano por não terem sido possível de encontrar. Todos eles foram evidenciados pelos documentos das Conferências e Declarações 
internacionais sobre assentamentos humanos e meio ambiente como sendo indispensáveis à construção de um ambiente urbano equilibrado, capaz de se reorganizar (resiliência) frente às constantes solicitações decorrentes da ocupação humana e que não esteja legando um passivo ambiental às demais gerações.

Contemporaneamente ao desfecho deste trabalho, está ocorrendo a aprovação dos novos planos diretores e suas adequações ao Estatuto da Cidade. Para a criação desta lei municipal ou seu ajuste, faz-se necessário um diagnóstico abrangente de todas as áreas de desenvolvimento dos municípios, o que por certo atualizará muitos dos dados que não bram encontrados para serem aplicados na Matriz de Indicadores de Qualidade de Vida Urbana, neste momento. O que por certo permitirá ter acesso a dados que não foram encontrados.

Tal ajuste pode indicar a possibilidade de novas pesquisas sobre os indicadores considerados relevantes para a composição de um ambiente urbano sustentável. 
5 CONCLUSÃO 
ão várias as indagações que puderam ser registradas sobres a pertinências - eficiência e eficácia - das políticas urbanas em dotarem o espaço urbano de sustentabilidade.

Frente aos dados analisados neste trabalho tem-se ao menos duas formas de abordagem para a questão. Espíndola (2006) afirma que a cidade de Governador Valadares mudou de cara depois das obras do convênio CPM/BIRD. Segundo o historiador, a cidade passou a ter ares de civilidade, com calçamento nas ruas, abastecimento de água e saneamento básico mais acessível à sua população.

Leite e Pereira (2004) falando de Montes Claros afirma que a presença do mesmo convênio cingiu a vida montes-clarence em dois tempos: um rural e outro urbano. Seguramente, a qualidade de vida rural pode ser repleta de boas características mas que não se referem à qualidade do ambiente urbano.

Pela análise da Matriz de Indicadores de Qualidade de Ambiente Urbano foi evidenciada a ação das políticas públicas alterando a qualidade geral do ambiente em Governador Valadares, Montes Claros e Uberlândia, evidenciada na análise advinda da grande transformação no gradiente de serviços urbanos oferecidos a partir do período de 1970. A partir da mesma análise têm-se os dados do crescimento acelerado de Uberlândia até os anos de 1990. Retomando a intenção de que desenvolvimento da região fosse voltado às atividades agro-industriais e de armazenamento e considerando sua posição estratégica em relação ao Distrito Federal e ao Centro-Sul do país, pode-se deduzir que se sua melhoria ambiental urbana se deu pela ação das políticas públicas, foi apenas uma potencialização inicial. A localização estratégica e as características geográficas seriam seguramente responsáveis pela dinamização do processo. 
Isto reforça o exposto por Serra (1991) em respeito ao fato de não ser possível afirmar que não ocorreria a mesma melhora ambiental na ausência das políticas públicas.

Neste sentido, Juiz de Fora e Poços de Caldas parecem não terem sido tão afetadas pelas políticas públicas do período, tendo no entanto, uma situação ambiental urbana melhor do que a de Governador Valadares de Montes Claros.

Assim sendo, frente à suas premissas para a política urbana, pode-se dizer que o II PND cumpriu em parte o estabelecido, ao proporcionar elevação de padrões de urbanização e qualidade de vida. Quanto á possibilidade de ter elevado a função urbana das cidades, parece que este intento ficou muito mais a cargo do PROECl, uma vez que o PNCCPM preocupourse muito mais com a infra-estrutura urbana, deixando para o programa estadual a preocupação com capacitação da população e ampliação do atendimento a serviços públicos, através da criação de creches, escolas e hospitais nas suas cidades de ação.

Muitos municípios tiveram que destinar quase a totalidade de sua capacidade de investimentos em infra-estrutura viária, o que conduziu ao reforço do conceito de rede urbana e diminuiu a possibilidade de ações diversificadas na qualidade do ambiente urbano.

Entende-se assim que a tese se confirma na maioria dos casos analisados, podendo ser considerada comprovada.

Quanto à proposição de uma melhor distribuição de população nacional, almejada tento pelo II PND quanto pelo PROECI, visando desconcentrar as cidadespólos, parece, como afirmado no próprio texto sobre tais políticas, que sua atividade foi concentradora e proporcionou atração população, exatamente pela concentração de investimentos em pontos estratégicos do território. Assim sendo, não há uma clara criação de novos pontos no território nacional, como estava contido na fala. 
Por conseqüência, não foi possível obter redução das disparidades interregionais ou inter-pessoais. Os dados revelam inclusive um aumento nas diferenças inter-pessoais, ou seja, um maior número de pobres no total da população de cada cidade.

Já em acordo com os objetivos do PROECl, não é possível garantir que tenha havido a efetiva a consolidação de um sistema de cidades de distintos níveis de hierarquia intentada pelo programa. Como não existe nenhum trabalho atual do governo do estado que posicione a hierarquia das funções urbanas, não há como afirmar que não sejam as mesmas cidades objeto de intervenção do programa que continuem a ser as que mais se projetam no cenário mineiro. Não há também como afirmar que estas cidades tenham passado a oferecer um maior número de funções urbanas.

O que é passível de afirmação é que aquelas que não eram cidade-pólo das regiões nas quais se enquadravam, hoje o são. O que indica que talvez as duas colocações acima tenham tido resultado positivo.

Outro objetivo do PROECl era o de dotar de maior solidez o sistema de cidades mineiro, através da já mencionada melhora na hierarquia das funções urbanas. No que diz respeito à hierarquia das cidades no cenário estadual e federal, pode-se assim delimitar: Uberlândia e Poços de Caldas continuam ligadas a São Paulo, Juiz de Fora ao Rio de Janeiro, Governador Valadares e Montes Claros na área de influência de Belo Horizonte (IPEA; IBGE; UNICAMP, 2001).

Assim sendo, as polarizações externas ainda são marcantes para o estado. E para efeito do trabalho aqui apresentado, sobre as cidades de melhor comportamento quanto à qualidade do ambiente urbano. A procurada integração espacial do estado, provavelmente não foi possibilitada frente a uma economia externa muito mais dinâmica do que a da capital mineira. 
Para efeito de análise sobre o tema sustentabilidade, aqui abordado, podese constatar que, para os fins a que se destina o trabalho, o recorte de características, transformadas em indicadores é bastante adequado a uma análise de ambiente urbano, se considerados seus aspectos físicos. Sendo a sustentabilidade um termo amplo, para o qual concorrem não somente características físicas do espaço, pode-se dizer que são muitas as caracterizações que devam estar presente para sua garantia e que provavelmente, os parâmetros para a aceitação estarão constantemente em ampliação, dificultando sempre sua completude.

O trabalho se encerra vislumbrando que a política urbana permanece necessária e imprescindível ao bom desenvolvimento das cidades pela evidência da necessidade de intervenção que seja externa a exclusiva - e excludente - lógica de mercado.

Refletir sobre a eficácia das políticas públicas urbanas é bastante apropriado para o momento vivido pelo país, no qual a obrigatoriedade da aprovação de planos diretores acaba de ter seu prazo estabelecido expirado.

O momento parece que será tão enriquecedor sobre o conhecimento a cerca das cidades, como aquele dos estudos das cidades médias, que provavelmente, farão juntamente com o II PND em seu capítulo sobre Política Nacional de Desenvolvimento Urbano, parte do marco sobre a política urbana no país.

Cabe ressaltar, no entanto, o avanço político conquistado nestes quase quarenta anos, quando a política urbana passa a ser participativa. Nas determinações feitas pelo Estatuto da Cidade, os planos diretores municipais terão necessariamente que contar com a participação de sua comunidade através de audiências públicas e ambém, através delas, que aprovarem os resultados finais encaminhados à aprovação na Câmara Municipal de Vereadores. 
Compreende-se que o caminho da reforma urbana, que assegure um ambiente digno de vida para todos os munícipes, está em construção. Construção esta que se inicia internamente aos governos centralizadores militares e que vem se desenvolvendo paulatinamente.

Entende-se que num país com a fragilidade social que vive o Brasil, a atuação do poder público, embora imprescindível, é poucas vezes eficiente e eficaz. Mas tendo o percentual de população que tem a margem de qualquer processo social, somente o estado poderá atuar de forma a reverter este quadro, seja nos campos da educação ambiental, seja nos campos da educação política.

Assim sendo, as ações da a política urbana no período delimitado por este trabalho não poder ser responsabilizada como a única responsável pela adequação das cidades, mas para algumas, trouxe uma considerável melhoria. 
ACIOLY Jr, Cláudio; DAVIDSON, Forbes. Densidade urbana: um instrumento de planajemento e gestão urbana. Rio de Janeiro: Mauad, 1998.

ACSELRAD, Henri. Discurso da sustentabilidade urbana. Revista Brasileira de Estudos Urbanos e Regionais, Recife, n. 1, maio 1999, p. 79-90.

ACSELRAD, Henri (org). A duração das cidades: sustentabilidade e risco das políticas urbanas. Rio de Janeiro: DP\&A, 2001.

ALMG. Assembléia Legislativa do Estado de Minas Gerais. O Estado: Macro e Microrregiões. Disponível em <http://www.almg.gov.br/index.asp?grupo= estado\&diretorio $=$ mregiao\&arquivo $=$ macrorregioes $>$. Acesso em: 02 set 2006 .

AMORIM FILHO, Oswaldo; SERRA, Rodrigo Valente. Evolução e perspectiva do papel das cidades médias no planejamento urbano e regional. In: ANDRADE, Thompson Almeida; SERRA, Rodrigo Valente. Cidades médias brasileiras. Rio de Janeiro: IPEA, 2001.

ANDRADE, Afrânio Alves de; MONTE-MÓR, Roberto Luiz de Melo. Urbanização e custos numa economia em desenvolvimento: o caso de Minas Gerais. Rio de Janeiro: PNPE, 1983.

ANDRÉS, Maurício. Ecologizar: pensando o ambiente humano. Belo Horizonte: Rona Editora, 1998.

ASSOCIAÇÃO BRASILEIRA DE NORMAS TÉCNICAS. NBR 10520/2002: Informação e documentação: citações em documentos - apresentação. Rio de Janeiro: ABNT, 2002.

ASSOCIAÇÃO BRASILEIRA DE NORMAS TÉCNICAS. NBR 14724/2002: Informação e documentação: trabalhos acadêmicos - apresentação. Rio de Janeiro: ABNT, 2002.

ASSOCIAÇÃO BRASILEIRA DE NORMAS TÉCNICAS. NBR 6023/2002: Informação e documentação: referências - elaboração. Rio de Janeiro: ABNT, 2002.

BENÉVOLO, Leonardo. Os princípios da urbanística moderna. São Paulo: Martins Fontes, 1981.

BERNARDES, Lysia. Política Urbana: uma análise da experiência brasileira. Análise e conjuntura, Belo Horizonte, n. 1, v. 1, p. 83-119, jan./abr. 1986.

BRASIL. Ministério das Cidades. Política Nacional de Desenvolvimento Urbano. Brasília: Ministério das Cidades, 2004. (Série: Cadernos MCidades)

BRASIL. Estatuto da Cidade. Lei n. 10.257, de 10 de julho de 2001. Brasília: Senado Federal, 2001.

BRASIL. Constituição (1988). Constituição da República Federativa do Brasil. Brasília: Senado Federal, 1988. 
BRASIL. Resolução nำ 01, de 20 de maio de 1980. Aprova as partes reformuladas do III Plano Nacional de Desenvolvimento (III PND), para os exercícios de 1980 a 1985. Diário Oficial, Brasília, 20 mai. 1980.

BRASIL. Lei Federal de Parcelamento de Solo (1979). Lei Federal n. 6.766, de 19 de dezembro de 1979, alterada pela Lei n. 9.785, de 29 de janeiro de 1999. Brasília: Senado Federal, 1979.

BRASIL. Ministério do Interior. Secretaria Geral. II Plano Nacional de Desenvolvimento; Programa de ação do governo na área do desenvolvimento urbano, 1975-1979. Brasília: Mln, 1975.

BRASIL. Lei n. 6.151, de 04 de dezembro de 1974. Dispõe sobre o II Plano Nacional de Desenvolvimento (II PND), para o período de 1975 a 1979. Diário Oficial, Brasília, DF, 06 dez. 1974.

BRASIL. Lei n. 5.727, de 04 de novembro de 1971. Dispõe sobre o I Plano Nacional de Desenvolvimento (I PND), para o período de 1972 a 1974. Diário Oficial, Brasília, DF, 17 dez. 1971.

BRASIL. Código Florestal. Lei n. 4.771, de 15 de setembro de 1965. Brasília: Senado Federal, 1965.

BRUNDTLAND, Gro Harlem. Nosso Futuro Comum. Relatório da Comissão Mundial sobre Meio Ambiente e Desenvolvimento. Rio de Janeiro: FGV, 1991.

CASTELLS, Manuel. The informational city: information technology, economic restructuring, and the urban-regional process. Oxford; Cambridge, Mass.: Blackwell, 1989.

CAPRA, Fritjof. Educação. In: TRIGUEIRO, André. Meio ambiente no século 21 21 especialistas falam da questão ambiental nas suas áreas de conhecimento. Rio de Janeiro: Sextante, 2003. p. 25.

CARDOSO, Adauto Lúcio. Reforma urbana e planos diretores: avaliação da experiência recente. Cadernos do IPPUR, Rio de Janeiro, Ano XI, nº 1 e 2, 1997, p. 79-111.

CINTRA, Antônio Octávio; HADDAD, Paulo Roberto (org). Dilemas do planejamento urbano e regional no Brasil. Rio de Janeiro: Zahar, 1977.

COSTA, Heloisa Soares de Moura. Desenvolvimento urbano sustentável: uma contradição de termos? Revista Brasileira de Estudos Urbanos e Regionais. Recife, n. 2, p. 55-71, mar 2000.

DIAS, Genebaldo Freire. Pegada ecológica e sustentabilidade humana: as dimensões humanas das alterações ambientais globais - um estudo de caso brasileiro. São Paulo: Gaia, 2002.

ESPÍNDOLA, Haruf Salmen. Associação Comercial de Governador Valadares: sessenta anos de história. Governador Valadares: ACGV, 1999. 
ESPÍNDOLA, Haruf Salmen. Desenvolvimento Urbano de Governador Valadares. Entrevistadora: E. Andrade. Governador Valadares: Univale, 2006. 1 cassete sonoro (90 min).

FAUUSP. Faculdade de Arquitetura e Urbanismo da Universidade de São Paulo. Avaliação do Programa Nacional de Capitais e Cidades de Porte Médio e Revisão de Critérios de Seleção das Referidas Cidades. São Paulo: FAUUSP, Minter-CNDU, 1984.

FJP. Fundação João Pinheiro. Estrutura Espacial do Estado de Minas Gerais. Belo Horizonte: FJP, 1986.

FJP. Fundação João Pinheiro. Estrutura espacial do estado de Minas Gerais. Belo Horizonte: FJP,1982

FJP. Fundação João Pinheiro. Programa Estadual de Centros Intermediários: concepção, metodologia e síntese. Belo Horizonte: FJP, 1980a.

FJP. Fundação João Pinheiro. Programa Estadual de Centros Intermediários: diagnóstico de Governador Valadares. Belo Horizonte: FJP, 1980b.

FJP. Fundação João Pinheiro. Programa Estadual de Centros Intermediários: diagnóstico de Poços de Caldas. Belo Horizonte: FJP, 1980c.

FJP. Fundação João Pinheiro. Programa Estadual de Centros Intermediários: diagnóstico de Uberlândia. Belo Horizonte: FJP, 1980d.

FRANCISCONI, José Guilherme; SOUZA, Maria Adélia Aparecida de. Política Nacional de Desenvolvimento Urbano: Estudos e proposições alternativas. Brasília: IPEA, IPLAN-CNDU, 1976.

FREITAS, Ruskin. Entre mitos e limites. Porto Alegre: UFRGS, 2005. (Tese de Doutorado em Arquitetura)

FÜHRER, Maximilianus C. A.; ÉDIS, Milaré. Manual de direito público e privado. São Paulo: Editora Revista dos Tribunais, 2003.

GUIMARÃES, José Ribeiro Soares; JANUZZI, Paulo de Martino. IDH, indicadores sintéticos e suas aplicações em políticas públicas. Revista Brasileira de Estudos Urbanos e Regionais. Recife, v. 7, n. 1, p. 73-90, mai. 2005.

IBGE. Instituto Brasileiro de Geografia e Estatística. Censo demográfico de 1960, 1970, 1980, 1990. Rio de Janeiro: IBGE, 1960.

IBGE. Instituto Brasileiro de Geografia e Estatística. Recenseamento Geral do Brasil de 1960. Minas Gerais. Série Regional. Volume 1, Tomo IX, Rio de Janeiro: IBGE.

IBGE. Instituto Brasileiro de Geografia e Estatística. Recenseamento Geral do Brasil de 1970. Minas Gerais. Volume 1, Tomo XIV - 1르 Parte. Rio de Janeiro: IBGE, 1973. 
IBGE. Instituto Brasileiro de Geografia e Estatística. Recenseamento Geral do Brasil de 1970. Minas Gerais. Volume 1, Tomo XIV - 2ª Parte. Rio de Janeiro: IBGE, 1973.

IBGE. Instituto Brasileiro de Geografia e Estatística. Recenseamento Geral do Brasil - 1980. Volume 1, Tomo 4, n. 18 X. Rio de Janeiro: IBGE, 1982.

IBGE. Instituto Brasileiro de Geografia e Estatística. Recenseamento Geral do Brasil - 1980. Volume 1, Tomo 6, n. 16. Rio de Janeiro: IBGE, 1982.

IBGE. Instituto Brasileiro de Geografia e Estatística. Recenseamento Geral do Brasil de 1991 - Migração - Minas Gerais. oㅜ 18. Rio de Janeiro: IBGE, 1992.

IBGE. Instituto Brasileiro de Geografia e Estatística. Recenseamento Geral do Brasil de 1991 - Resultados do Universo relativo às características da população e dos domicílios. Minas Gerais. oㅜ 18. Rio de Janeiro: IBGE, 1992.

IBGE. Instituto Brasileiro de Geografia e Estatística. Sistema IBGE de Recuperação Automática (SIDRA). Disponível em: <http://www.ibge.gov.br/home/\#>. Acesso em : 02 set 2006.

IGA. Instituto de Geociência Aplicada. 1999. Mapas de situação dos municípios de Montes Claros, Poços de Caldas, Juiz de Fora, Governador Valadares. 1999. Disponível em: INDI. Municípios Mineiros. <http://www.indi.mg.gov.br>. Acesso em: 014 set. 2006.

IPEA; IBGE; UNICAMP. Estudos básicos para caracterização da Rede Urbana. Brasília: IPEA, 2001. (Série Caracterização regional e estruturação da rede urbana. IPEA. IBGE. UNICAMP. Série de 06 volumes).

LEFEBVRE, Henri. A revolução urbana. Belo Horizonte: UFMG, 1999.

LEITE, Marco Esdras; PEREIRA, Anete Marília. A expansão urbana de Montes Claros a partir do processo de industrialização. In: PEREIRA, Anete Marília; ALMEIDA, Maria Ivete Soares de. Leituras geográficas sobre o norte de Minas Gerais. Montes Claros: Editora Unimontes, 2004.

MARCONI, Marina de Andrade; LAKATOS, Eva Maria. Fundamentos de metodologia científica. São Paulo: Atlas, 2005.

MATOS, Ralfo (org). Espacialidades em rede: população, urbanização e migração no Brasil contemporâneo. Belo Horizonte: C/Arte, 2005.

MEDAUAR, Odete. Constituição Federal: Coletânea de Legislação de Direito Ambiental. São Paulo: Editora Revista dos Tribunais, 2002.

MELLO, João Manuel Cardoso de; NOVAIS, Fernando A. Capitalismo tardio e sociabilidade moderna. In: NOVAIS, Fernando A. História da Vida Privada no Brasil: contrastes da intimidade contemporânea. São Paulo: Companhia das Letras, 1998. p. 559-558. 
MENDONÇA, Jupira Gomes de. Programa Estatal de Ciudades Intermediárias de Minas Gerais: la falacia de las políticas urbanas no Brasil. Mexico: Universidad Nacional Autonoma de Mexico, 1990. (Dissertação de Mestrado em Arquitetura).

MIRANDA, E. E. de; GOMES, E. G. GUIMARÃES, M. Mapeamento e estimativa da área urbanizada do Brasil com base em imagens orbitais e modelos estatísticos. Campinas: Embrapa Monitoramento por Satélite, 2005. Disponível em: <http://www.urbanizacao.cnpm.embrapa.br>. Acesso em: 22 nov. 2006.

MONTE-MÓR, Roberto Luiz de Melo. Do urbanismo a política urbana: notas sobre a experiência brasileira. Belo Horizonte: CEDEPLAR/UFMG, 1981. 43p. Série (Textos para discussão: 11)

NOBRE, Marcos; AMAZONAS, M. C. Desenvolvimento sustentável: a institucionalização do conceito. São Paulo GEBRAP/IBAMA, 2002.

ONU. Organização das Nações Unidas. Conferência Mundial de Estocolmo. 1973. Disponível em: <http://www.onu.br>. Acesso em: 7 set. 2006.

ONU. Organização das Nações Unidas. Conferência Mundial de Vancouver. 1976. Disponível em: <http://www.onu.br>. Acesso em: 7 set. 2006.

ONU. Organização das Nações Unidas. Conferência Mundial do Rio de Janeiro. 1992. Disponível em: <http://www.onu.br>. Acesso em: 7 set. 2006.

ONU. Organização das Nações Unidas. Conferência Mundial de Istambul. 1996. Disponível em: <http://www.onu.br>. Acesso em: 7 set. 2006.

PIQUET, Rosélia; RIBEIRO, Ana Clara Torres (org). Brasil, território da desigualdade: Descaminhos da Modernização. Rio de Janeiro: Jorge Zahar, Fundação Universitária José Bonifácio, 1991.

PNUD; IPEA; FJP. Atlas do Desenvolvimento Humano no Brasil. Versão 1.0.0. [s. I.]: ESM Consultoria, 2003. Disponível em: <http://www.pnud.org.br/atlas/>. Acesso em: 10 set. 2006.

PREFEITURA Municipal de Belo Horizonte - PBH. Índice de Qualidade de Vida Urbana. Belo Horizonte: Assessoria de Comunicação Social, 1996.

PREFEITURA Municipal de Juiz de Fora. Projeto de Modernização do Sistema de Transporte e Circulação de Juiz de Fora. Juiz de Fora: Prefeitura Municipal de Juiz de Fora; Diretoria de Planejamento e Gestão Estratégica, 2002.

PREFEITURA Municipal de Juiz de Fora. Lei Municipal n. 9.811, de 27 de junho de 2000. Plano Diretor de Desenvolvimento Urbano (PDDU). Disponível em: <http://www.pjf.mg.gov.br/pddu/index.htm>. Acesso em: 3 set 2006.

PREFEITURA Municipal de Poços de Caldas. Secretaria de Planejamento e Coordenação. Plano Diretor. Poços de Caldas: Prefeitura Municipal, Secretaria de Planejamento e Coordenação, 1992. 
PREFEITURA Municipal de Poços de Caldas. Planejamento. Lei Municipal n. 4.161. Lei de Uso e Ocupação do Solo. Disponível em: <www.pocosdecaldas.mg.gov.br>. Acesso em: 11 set. 2006.

PREFEITURA Municipal de Governador Valadares. Plano Diretor Municipal. Governador Valadares: Prefeitura Municipal, 1991.

PREFEITURA Municipal de Uberlândia. Secretaria de Planejamento Urbano e Meio Ambiente. Divisão de Planejamento Integrado. Lei Complementar n. 245/2000. Parcelamento e Zoneamento do Uso e Ocupação do Solo do Município de Uberlândia. 2000. Disponível em: <www.uberlandia.mg.gov.br>. Acesso em: 3 set. 2006.

REIS, Nestor Goulart. Urbanização e Planejamento no Brasil - 1960/1983. São Paulo: FAUUSP, 1996. (Cadernos de Pesquisa do LAP - Série Urbanização e Urbanismo)

SANTILLI, Juliana. Socioambientalismo e novos direitos: proteção jurídica à diversidade biológica e cultural. São Paulo: Peirópolis, 2005.

SAULE JÚNIOR, Nelson (coord.). Direito à cidade: trilhas legais para o direito às cidades sustentáveis. São Paulo: Pólis, Max Limonad, 2001.

SCHMIDT, Alfred. O conceito da natureza em Marx.1962.

SERRA, Geraldo. Urbanização e centralismo autoritário. São Paulo: EDUSP/NOBEL, 1991.

SINGER, Paul. Desenvolvimento econômico e evolução urbana: análise da evolução econômica de São Paulo, Blumenau, Porto Alegre, Belo Horizonte e Recife. 2. ed. São Paulo: Companhia Editora Nacional, 1977.

SOUZA, Maria Adélia Aparecida de. O II PND e a política brasileira: uma contradição evidente. In: DEÁK, Csaba; SCHIFFER, Sueli Ramos (orgs). O processo de urbanização no Brasil. São Paulo: EDUSP, 2004.

TRIGUEIRO, André. Meio ambiente no século 21: 21 especialistas falam da questão ambiental nas suas áreas de conhecimento. Rio de Janeiro: Sextante, 2003. 


\section{APÊNDICE}

\section{APÊNDICE 1 - Valor da moeda nacional em relação ao dólar em cada década}

\begin{tabular}{|c|r|r|r|}
\hline Ano & Valor do Dólar41 & Valor necessário para um mês 42 & \multicolumn{1}{c|}{ Valor total } \\
\hline 1970 & $\mathrm{CR} \$ 4,46$ & $\mathrm{CR} \$ 8,92 \times 30$ & $\mathrm{CR} \$ 26,76$ \\
\hline 1980 & $\mathrm{CR} \$ 50,61$ & $\mathrm{CR} \$ 101,21 \times 30$ & $\mathrm{CR} \$ 3036,3$ \\
\hline 1990 & $\mathrm{CR} \$ 54,98$ & $\mathrm{CR} \$ 109,96 \times 30$ & $\mathrm{CR} \$ 3298,8$ \\
\hline 2000 & $\mathrm{R} \$ 1,82$ & $\mathrm{CR} \$ 3,33 \times 30$ & $\mathrm{CR} \$ 54,78$ \\
\hline
\end{tabular}

FONTE: Banco Central.

\section{APÊNDICE 2 - Valor do Salário Mínimo Brasileiro}

\begin{tabular}{|c|r|c|}
\hline \multicolumn{1}{|c|}{ Ano } & Valor & Correlação dólar/salário 43 \\
\hline 1970 & $\mathrm{CR} \$ 187,00$ & Mais de um salário \\
\hline 1980 & $\mathrm{CR} \$ 4149,60$ & $3 / 4$ do salário \\
\hline 1990 & $\mathrm{CR} \$ 3674,06$ & $90 \%$ do salário \\
\hline 2000 & $\mathrm{R} \$ 151,00$ & $36 \%$ do salário \\
\hline
\end{tabular}

FONTE: Banco Central.

41 A cotação do dólar adotada para cada ano é aquela mais próxima ao mês de maio, no qual sai o valor do novo salário mínimo.

42 O valor aqui considerado é de US\$2,0 para sobrevivência por dia, para que uma pessoa esteja acima do limiar da pobreza.

43 A correlação dólar/salário mínimo estabelece quanto relativamente seria necessário para que uma pessoa estivesse acima do limiar da pobreza. 


\section{ANEXOS}

Tabela 1436 - Domicílios particulares permanentes e Moradores em Domicílios particulares permanentes por situação e abastecimento de água

\begin{tabular}{|c|c|}
\hline Variável & Domicílios particulares permanentes (Unidade) \\
\hline Governador Valadares - MG & 62172 \\
\hline Juiz de Fora - MG & 126245 \\
\hline Montes Claros - MG & 70129 \\
\hline Poços de Caldas - MG & 37742 \\
\hline Uberlândia - MG & 141113 \\
\hline
\end{tabular}

FONTE: IBGE.

Tabela 156 - Média de moradores por domicílio (Variável = Média de moradores por domicílio (Pessoas); Ano = 2000)

\begin{tabular}{|l|r|}
\hline \multicolumn{1}{|c|}{ Brasil, Região Geográfica e Município } & \multicolumn{1}{c|}{ Moradores por domicílio } \\
\hline Brasil & 3,73 \\
\hline Sudeste & 3,52 \\
\hline Governador Valadares - MG & 3,69 \\
\hline Juiz de Fora - MG & 3,39 \\
\hline Montes Claros - MG & 4,01 \\
\hline Poços de Caldas - MG & 3,37 \\
\hline Uberlândia - MG & 3,44 \\
\hline
\end{tabular}

FONTE: IBGE.

Tabela 161 - Média de moradores por domicílio por situação (Variável = Média de moradores por domicílio (Pessoas); Situação do domicílio = Urbana; Ano = 2000)

\begin{tabular}{|l|r|}
\hline \multicolumn{1}{|c|}{ Brasil, Região Geográfica e Município } & \multicolumn{1}{c|}{ Moradores por domicílio urbano } \\
\hline Brasil & 3,64 \\
\hline Sudeste & 3,49 \\
\hline Governador Valadares - MG & 3,70 \\
\hline Juiz de Fora - MG & 3,39 \\
\hline Montes Claros - MG & 4,02 \\
\hline Poços de Caldas - MG & 3,35 \\
\hline Uberlândia - MG & 3,44 \\
\hline
\end{tabular}

FONTE: IBGE. 
Tabela 1437 - Domicílios particulares permanentes e Moradores em Domicílios particulares permanentes por situação e tipo do esgotamento sanitário (Situação do domicílio = Total; Variável $=$ Domicílios particulares permanentes (Unidade); Ano $=2000$ )

\begin{tabular}{|c|c|c|}
\hline Brasil, Região Geográfica, Unidade da Federação e Município & Tipo de esgotamento sanitário & \\
\hline \multirow{8}{*}{ Brasil } & Total & 44.795 .101 \\
\hline & Rede geral de esgoto ou pluvial & 21.160 .735 \\
\hline & Fossa séptica & 6.699 .715 \\
\hline & Fossa rudimentar & 10.594 .752 \\
\hline & Vala & 1.154 .910 \\
\hline & Rio, lago ou mar & 1.110 .021 \\
\hline & Outro escoadouro & 369.660 \\
\hline & Não tinham banheiro nem sanitário & 3.705 .308 \\
\hline \multirow{8}{*}{ Sudeste } & Total & 20.224 .269 \\
\hline & Rede geral de esgoto ou pluvial & 14.847 .655 \\
\hline & Fossa séptica & 1.803.107 \\
\hline & Fossa rudimentar & 1.791 .029 \\
\hline & Vala & 545.768 \\
\hline & Rio, lago ou mar & 761.618 \\
\hline & Outro escoadouro & 129.732 \\
\hline & Não tinham banheiro nem sanitário & 345.360 \\
\hline \multirow{8}{*}{ Governador Valadares - MG } & Total & 65.827 \\
\hline & Rede geral de esgoto ou pluvial & 53.535 \\
\hline & Fossa séptica & 4.618 \\
\hline & Fossa rudimentar & 2.692 \\
\hline & Vala & 726 \\
\hline & Rio, lago ou mar & 2.177 \\
\hline & Outro escoadouro & 425 \\
\hline & Não tinham banheiro nem sanitário & 1.654 \\
\hline \multirow{8}{*}{ Juiz de Fora - MG } & Total & 132.465 \\
\hline & Rede geral de esgoto ou pluvial & 123.522 \\
\hline & Fossa séptica & 1.305 \\
\hline & Fossa rudimentar & 1.453 \\
\hline & Vala & 628 \\
\hline & Rio, lago ou mar & 4.258 \\
\hline & Outro escoadouro & 940 \\
\hline & Não tinham banheiro nem sanitário & 359 \\
\hline \multirow{8}{*}{ Montes Claros - MG } & Total & 75.676 \\
\hline & Rede geral de esgoto ou pluvial & 64.653 \\
\hline & Fossa séptica & 891 \\
\hline & Fossa rudimentar & 6.945 \\
\hline & Vala & 76 \\
\hline & Rio, lago ou mar & 257 \\
\hline & Outro escoadouro & 145 \\
\hline & Não tinham banheiro nem sanitário & 2.709 \\
\hline
\end{tabular}


(continuação)

\begin{tabular}{|l|l|r|}
\hline Brasil, Região Geográfica, Unidade da Federação e Município & Tipo de esgotamento sanitário & 39.701 \\
\hline \multirow{5}{*}{ Poços de Caldas - MG } & Total & 37.288 \\
\cline { 2 - 3 } & Rede geral de esgoto ou pluvial & 585 \\
\cline { 2 - 3 } & Fossa séptica & 641 \\
\cline { 2 - 3 } & Fossa rudimentar & 219 \\
\cline { 2 - 3 } & Vala & 884 \\
\cline { 2 - 3 } & Rio, lago ou mar & 12 \\
\cline { 2 - 3 } & Outro escoadouro & 72 \\
\cline { 2 - 3 } & Não tinham banheiro nem sanitário & 144.461 \\
\hline \multirow{5}{*}{ Uberlândia - MG } & Total & 138.719 \\
\cline { 2 - 3 } & Rede geral de esgoto ou pluvial & 1.431 \\
\cline { 2 - 3 } & Fossa séptica & 3.623 \\
\cline { 2 - 3 } & Fossa rudimentar & 119 \\
\cline { 2 - 3 } & Vala & 84 \\
\cline { 2 - 3 } & Rio, lago ou mar & 57 \\
\cline { 2 - 3 } & Outro escoadouro & 428 \\
\cline { 2 - 3 } & Não tinham banheiro nem sanitário & \\
\hline
\end{tabular}

FONTE: Disponível em: <http://noblat.plugin.com.br/arquivo/mais_voce.wm». Acesso em: 14 set. 2006

População total - Décadas 60,70,80 e 90

\begin{tabular}{|l|r|r|r|r|}
\hline \multicolumn{1}{|c|}{ Municípios } & $\begin{array}{c}\text { População total por } \\
\text { Município para 60 }\end{array}$ & $\begin{array}{c}\text { População total por } \\
\text { Município para 70 }\end{array}$ & $\begin{array}{c}\text { População total por } \\
\text { Município para 80 }\end{array}$ & $\begin{array}{c}\text { População total por } \\
\text { Município para 90 }\end{array}$ \\
\hline Juiz de Fora & 181389 & 238502 & 301545 & 385996 \\
\hline Poços de Caldas & 38198 & 57643 & 86972 & 110123 \\
\hline Montes Claros & 131337 & 116464 & 162422 & 250062 \\
\hline Uberlândia & 87678 & 124895 & 235328 & 367061 \\
\hline Governador Valadares & 120602 & 162333 & 179002 & 230524 \\
\hline
\end{tabular}

FONTE: IBGE.

População rural/urbana - Décadas 60,70,80 e 90

\begin{tabular}{|l|l|r|r|r|r|r|r|}
\hline \multirow{2}{*}{ Municípios } & \multicolumn{9}{|c|}{ População residente } \\
\cline { 2 - 8 } & \multirow{2}{*}{ Década 60 } & \multicolumn{2}{|c|}{ Década 70 } & \multicolumn{2}{c|}{ Década 80 } & \multicolumn{2}{c|}{ Década 90 } \\
\cline { 3 - 8 } & & \multicolumn{1}{|c|}{ Urbana } & \multicolumn{1}{c|}{ Rural } & Urbana & \multicolumn{1}{c|}{ Rural } & \multicolumn{1}{c|}{ Urbana } & \multicolumn{1}{c|}{ Rural } \\
\hline Governador Valadares & Não disponível & 129647 & 32686 & 173624 & 5378 & 215098 & 15426 \\
\hline Juiz de Fora & Não disponível & 220286 & 18216 & 299432 & 2113 & 380249 & 5747 \\
\hline Poços de Caldas & Não disponível & 51844 & 5799 & 81440 & 5532 & 105205 & 4918 \\
\hline Montes Claros & Não disponível & 85072 & 31392 & 151713 & 10709 & 227759 & 22303 \\
\hline Uberlândia & Não disponível & 111640 & 13255 & 230185 & 5143 & 358165 & 8896 \\
\hline
\end{tabular}

FONTE: IBGE. 


\section{Governador Valadares}

\begin{tabular}{|l|r|r|r|r|}
\hline \multicolumn{1}{|c|}{ Setor de atividade } & Década de 60 & Década de 70 & Década de 80 & Década de 90 \\
\hline Agricultura, pecuária, silvicultura e atividades extrativas & 56085 & 38784 & 16026 & 6526 \\
\hline Atividades Industriais & 14123 & 1039 & 34647 & 22921 \\
\hline Comércio de mercadorias & & 1039 & 19016 & 22517 \\
\hline Prestação de serviços & & 2078 & 25964 & 21830 \\
\hline Transporte, comunicação e armazenagem & \multirow{4}{*}{$43769(1)$} & 14116 & 44980 & 4956 \\
\hline Atividades sociais & & 16194 & 7252 & 7843 \\
\hline Administração pública & & 6962 & 5719 & 2816 \\
\hline Outras atividades & & 23156 & 2043 & 4793 \\
\hline TOTAL & & 25234 & 44980 & 94202 \\
\hline
\end{tabular}

(1) A tabela não possui as subdivisões comércio de mercadorias; prestação de serviços; transporte, comunicação e armazenagem; atividades sociais; atividades públicas. Estes setores estão inclusos no setor Outras atividades

FONTE: IBGE.

\section{Juiz de Fora}

\begin{tabular}{|c|c|c|c|c|}
\hline Setor de atividade & Década de 60 & Década de 70 & Década de 80 & Década de 90 \\
\hline Agricultura, pecuária, silvicultura e atividades extrativas & 32911 & 17879 & 7959 & 1491 \\
\hline Atividades Industriais & 34789 & 43936 & 65466 & 45466 \\
\hline Comércio de mercadorias & \multirow{6}{*}{$90243(1)$} & 21416 & 22904 & 22517 \\
\hline Prestação de serviços & & 29135 & 40428 & 35634 \\
\hline Transporte, comunicação e armazenagem & & 16833 & 15699 & 9994 \\
\hline Atividades sociais & & 13398 & 17744 & 18080 \\
\hline Administração pública & & 19993 & 14560 & 8997 \\
\hline Outras atividades & & 14049 & 6719 & 12516 \\
\hline TOTAL & 157943 & 176639 & 191479 & 154695 \\
\hline
\end{tabular}

(1) A tabela não possui as subdivisões comércio de mercadorias; prestação de serviços; transporte, comunicação e armazenagem; atividades sociais; atividades públicas. Estes setores estão inclusos no setor Outras atividades

FONTE: IBGE.

\section{Poços de Caldas}

\begin{tabular}{|c|c|c|c|c|}
\hline Setor de atividade & Década de 60 & Década de 70 & Década de 80 & Década de 90 \\
\hline Agricultura, pecuária, silvicultura e atividades extrativas & 9578 & 8542 & 5092 & 3675 \\
\hline Atividades Industriais & 5704 & 16648 & 25320 & 15613 \\
\hline Comércio de mercadorias & \multirow{6}{*}{ 19682(1) } & 5793 & 6946 & 7622 \\
\hline Prestação de serviços & & 9976 & 11584 & 10883 \\
\hline Transporte, comunicação e armazenagem & & 4820 & 3429 & Não disponível \\
\hline Atividades sociais & & 2219 & 3307 & 3928 \\
\hline Administração pública & & 1604 & 2364 & 1842 \\
\hline Outras aividades & & 3002 & 1835 & 1312 \\
\hline TOTAL & 34964 & 52604 & 59877 & 44875 \\
\hline
\end{tabular}

(1) A tabela não possui as subdivisões comércio de mercadorias; prestação de serviços; transporte, comunicação e armazenagem; atividades sociais; atividades públicas. Estes setores estão inclusos no setor Outras atividades

FONTE: IBGE. 


\section{Montes Claros}

\begin{tabular}{|l|r|r|r|r|}
\hline \multicolumn{1}{|c|}{ Setor de atividade } & Década de 60 & Década de 70 & Década de 80 & Década de 90 \\
\hline Agricultura, pecuária, silvicultura e atividades extrativas & 84546 & 38714 & 21028 & 10489 \\
\hline Atividades Industriais & 8906 & 21278 & 32476 & 23300 \\
\hline Comércio de mercadorias & & 11162 & 14029 & 16279 \\
\hline Prestação de serviços & & 32440 & 20169 & 22215 \\
\hline Transporte, comunicação e armazenagem & \multirow{2}{*}{$32750(1)$} & 7748 & 5770 & 4165 \\
\cline { 1 - 3 } \cline { 4 - 5 } Atividades sociais & & 4993 & 7582 & 9349 \\
\cline { 1 - 3 } Administração pública & & 12741 & 6464 & 4505 \\
\hline Outras atividades & & 4599 & 2581 & 4616 \\
\hline TOTAL & 126202 & 45181 & 110099 & 94918 \\
\hline
\end{tabular}

(1) A tabela não possui as subdivisões comércio de mercadorias; prestação de serviços; transporte, comunicação e armazenagem; atividades sociais; atividades públicas. Estes setores estão inclusos no setor Outras atividades

FONTE: IBGE.

\section{Uberlândia}

\begin{tabular}{|c|c|c|c|c|}
\hline Setor de atividade & Década de 60 & Década de 70 & Década de 80 & Década de 90 \\
\hline Agricultura, pecuária, silvicultura e atividades extrativas & 20521 & 20573 & 18757 & 9167 \\
\hline Atividades Industriais & 15293 & 26492 & 48685 & 39256 \\
\hline Comércio de mercadorias & \multirow{6}{*}{$44508(1)$} & 20334 & 28531 & 33072 \\
\hline Prestação de serviços & & 19206 & 37036 & 38516 \\
\hline Transporte, comunicação e armazenagem & & 11268 & 12373 & 10807 \\
\hline Atividades sociais & & 3707 & 110 & 15996 \\
\hline Administração pública & & 3259 & 32 & 5064 \\
\hline Outras atividades & & 6346 & 4997 & 11275 \\
\hline TOTAL & 80322 & 111185 & 150521 & 163153 \\
\hline
\end{tabular}

(1) A tabela não possui as subdivisões comércio de mercadorias; prestação de serviços; transporte, comunicação e armazenagem; atividades sociais; atividades públicas. Estes setores estão inclusos no setor Outras atividades.

FONTE: IBGE.

\section{Abastecimento de água}

\begin{tabular}{|c|c|c|c|c|c|c|c|c|}
\hline \multirow{3}{*}{ Municípios } & \multicolumn{2}{|c|}{ Década de 60} & \multicolumn{2}{|c|}{ Década de 70} & \multicolumn{2}{|c|}{ Década de 80} & \multicolumn{2}{|c|}{ Década de 90} \\
\hline & \multicolumn{2}{|c|}{ Abastecimento de água } & \multicolumn{2}{|c|}{ Abastecimento de água } & Abasteci & ento de água & Abasteci & nento de água \\
\hline & $\begin{array}{l}\text { Rede } \\
\text { geral }\end{array}$ & $\begin{array}{l}\text { Poços ou } \\
\text { nascentes }\end{array}$ & $\begin{array}{l}\text { Rede } \\
\text { geral }\end{array}$ & $\begin{array}{l}\text { Poços ou } \\
\text { nascentes }\end{array}$ & $\begin{array}{l}\text { Rede } \\
\text { geral }\end{array}$ & $\begin{array}{l}\text { Poços ou } \\
\text { nascentes }\end{array}$ & $\begin{array}{l}\text { Rede } \\
\text { geral }\end{array}$ & $\begin{array}{l}\text { Poços ou } \\
\text { nascentes }\end{array}$ \\
\hline Governador Valadares & 5460 & 8683 & 13379 & 13468 & 32030 & 5497 & 47847 & 1598 \\
\hline Juiz de Fora & 21008 & 7730 & 29440 & 11467 & 52327 & 13918 & 92764 & 5094 \\
\hline Poços de Caldas & 5091 & 1267 & 8234 & 2473 & 14232 & 5706 & 25281 & 2568 \\
\hline Montes Claros & 2767 & 1509 & 8631 & 2409 & 18081 & 11185 & 45867 & 3339 \\
\hline Uberlândia & 7175 & 5097 & 15815 & 6531 & 47903 & 4481 & 90194 & 1639 \\
\hline
\end{tabular}

FONTE: IBGE.

\section{Instalações sanitárias}

\begin{tabular}{|c|c|c|c|c|c|c|c|c|c|c|c|c|c|c|c|}
\hline \multirow{3}{*}{ Municípios } & \multicolumn{3}{|c|}{ Década 60} & \multicolumn{4}{|c|}{ Década 70} & \multicolumn{4}{|c|}{ Década de 80} & \multicolumn{4}{|c|}{ Década de 90} \\
\hline & \multicolumn{3}{|c|}{ Instalações Sanitárias } & \multicolumn{4}{|c|}{ Instalações Sanitárias } & \multicolumn{4}{|c|}{ Instalações Sanitárias } & \multicolumn{4}{|c|}{ Instalações Sanitárias } \\
\hline & \begin{tabular}{|l|} 
Rede \\
geral
\end{tabular} & \begin{tabular}{|c|c|} 
Fossa & Fossa \\
séptica & rud. \\
\end{tabular} & Outrc & $\begin{array}{l}\text { Rede } \\
\text { geral }\end{array}$ & $\begin{array}{c}\text { Fossa } \\
\text { séptica }\end{array}$ & \begin{tabular}{|c|} 
Fossa \\
rud.
\end{tabular} & Outro & \begin{tabular}{|l|} 
Rede \\
geral
\end{tabular} & $\begin{array}{l}\text { Fossa } \\
\text { séptica }\end{array}$ & $\begin{array}{c}\text { Fossa } \\
\text { rud. }\end{array}$ & Out & $\begin{array}{l}\text { Rede } \\
\text { Geral }\end{array}$ & \begin{tabular}{|c|} 
Fossa \\
Séptica
\end{tabular} & $\begin{array}{l}\text { Fossa } \\
\text { rud. }\end{array}$ & $\mathrm{Ou}$ \\
\hline Governador Valadares & 3193 & \begin{tabular}{|l|l|}
2161 & 5353 \\
\end{tabular} & 894 & 6534 & 1909 & 10352 & 1676 & 23133 & 124 & 10318 & 2085 & 37662 & 115 & 6994 & 3403 \\
\hline Juiz de Fora & 19956 & \begin{tabular}{lll|}
1856 & 4147 \\
\end{tabular} & 2874 & 26453 & 1804 & 7793 & 4218 & 51721 & 5681 & 4788 & 3851 & 90505 & 2639 & 1393 & 2779 \\
\hline Poços de Caldas & 4729 & \begin{tabular}{|l|l|}
526 & 1033 \\
\end{tabular} & 137 & 6402 & 615 & 3290 & 418 & 14406 & 1593 & 2862 & 760 & 25640 & 949 & 1172 & 740 \\
\hline Montes Claros & 2161 & \begin{tabular}{|l|l|}
599 & 1864 \\
\end{tabular} & 598 & 4379 & 576 & 7107 & 321 & 11860 & 1236 & 13694 & 429 & 36298 & 348 & 10178 & 534 \\
\hline Uberlândia & 6129 & \begin{tabular}{ll|}
825 & 4748 \\
\end{tabular} & 493 & 12477 & 565 & 8883 & 461 & 42223 & 548 & 8004 & 116 & 86201 & 373 & 4747 & 166 \\
\hline
\end{tabular}

FONTE: IBGE. 


\section{Iluminação elétrica}

\begin{tabular}{|c|c|c|c|c|c|c|c|c|}
\hline \multirow{2}{*}{ Municípios } & \multicolumn{2}{|c|}{ Década 60} & \multicolumn{2}{|c|}{ Década 70} & \multicolumn{2}{|c|}{ Década 80} & \multicolumn{2}{|c|}{ Década 90} \\
\hline & Domicílios & Iluminação & Domicílios & Iluminação & Domicílios & Iluminação & Domicílios & Iluminação \\
\hline Governador Valadares & 21930 & 5354 & 28615 & 13468 & 39926 & 33033 & 53895 & 52005 \\
\hline Juiz de Fora & 33934 & 27701 & 44866 & 39259 & 69099 & 65474 & 100388 & 99202 \\
\hline Poços de Caldas & 7735 & 6491 & 11934 & 9947 & 20564 & 19469 & 54245 & 28846 \\
\hline Montes Claros & 21463 & 3943 & 19736 & 7669 & 33354 & 24347 & 29025 & 5074 \\
\hline Uberlândia & 16900 & 11524 & 25014 & 18325 & 53553 & 47140 & 94237 & 92799 \\
\hline
\end{tabular}

FONTE: IBGE.

Utilidades existentes - Fogão 60 e 70

\begin{tabular}{|c|c|c|c|c|c|c|c|c|}
\hline \multirow{3}{*}{ Municípios } & \multicolumn{4}{|c|}{ Década 60} & \multicolumn{4}{|c|}{ Década 70} \\
\hline & \multirow{2}{*}{ Domicílios } & \multicolumn{3}{|c|}{ Fogão } & \multirow{2}{*}{ Domicílios } & \multicolumn{3}{|c|}{ Fogão } \\
\hline & & Lenha & Gás & Outro combustíve & & Lenha & Gás & Outro combustível \\
\hline Governador Valadares & 21930 & 20244 & 964 & 224 & 28615 & 13082 & 14876 & 126 \\
\hline Juiz de Fora & 33934 & 16578 & 13841 & 3057 & 44866 & 6395 & 37613 & 393 \\
\hline Poços de Caldas & 7735 & 4942 & 1997 & 715 & 11934 & 2669 & 9062 & 95 \\
\hline Montes Claros & 21463 & 19853 & 613 & 116 & 19736 & 12222 & 7209 & 37 \\
\hline Uberlândia & 16900 & 12810 & 3185 & 637 & 25014 & 7007 & 17648 & 60 \\
\hline
\end{tabular}

FONTE: IBGE.

Utilidades existentes - Rádio e Geladeira 60, 70, 80 e 90

\begin{tabular}{|c|c|c|c|c|c|c|c|c|c|c|c|}
\hline & \multicolumn{3}{|c|}{ Década 60} & \multicolumn{3}{|c|}{ Década 70} & \multicolumn{3}{|c|}{ Década 80} & \multicolumn{2}{|l|}{ Década 90} \\
\hline & Domicílios & Radio & Geladeira & Domicílios $\mathrm{F}$ & Radio & Geladeira & Domicílios & Radio & Geladeira & \begin{tabular}{|l|l|} 
Domicílios Radio \\
\end{tabular} & Geladeira \\
\hline Gove & 21930 & 4818 & 1575 & 286151 & 16641 & 7067 & 39926 & 29937 & 23292 & \begin{tabular}{|l|l|}
53895 & 43367 \\
\end{tabular} & 41470 \\
\hline Juiz de Fora & 33934 & 23806 & 6918 & 44866 & 36282 & 19149 & 69099 & 59644 & 49109 & 10038894009 & 87515 \\
\hline Poço & 7735 & 5208 & 977 & 11934 & 9105 & 3793 & 20564 & 17470 & 13342 & \begin{tabular}{|l|l|}
29025 & 26918 \\
\end{tabular} & 25160 \\
\hline Mont & 21463 & 3465 & 816 & 197361 & 10331 & 3583 & 33354 & 25427 & 14952 & \begin{tabular}{|l|l|}
54245 & 45869 \\
\end{tabular} & 34209 \\
\hline Uberlândia & 16900 & 9595 & 2568 & 250141 & 18126 & 8034 & 53553 & 42400 & 32396 & 9423786009 & 81242 \\
\hline
\end{tabular}

FONTE: IBGE.

\section{Utilidades existentes -TV e Automóvel 70, 80 e 90}

\begin{tabular}{|c|c|c|c|c|c|c|c|c|c|}
\hline \multirow{2}{*}{ Municípios } & \multicolumn{3}{|c|}{ Década 70} & \multicolumn{3}{|c|}{ Década 80} & \multicolumn{3}{|c|}{ Década 90} \\
\hline & Domicílios & Televisão & Automóvel & Domicílios & Televisão & Automóvel & Domicílios & Televisão & Automóvel \\
\hline Governador Valadares & 28615 & 6165 & 2187 & 39926 & 25605 & 7522 & 53895 & 47289 & 13510 \\
\hline Juiz de Fora & 44866 & 22197 & 6383 & 69099 & 59831 & 18948 & 100388 & 110917 & 33689 \\
\hline Poços de Caldas & 11934 & 5119 & 1920 & 20564 & 17216 & 6833 & 29025 & 29133 & 12299 \\
\hline Montes Claros & 19736 & 1836 & 1499 & 33354 & 18860 & 6506 & 54245 & 42062 & 12485 \\
\hline Uberlândia & 25014 & 9849 & 3041 & 53553 & 42482 & 15762 & 94237 & 92021 & 36579 \\
\hline
\end{tabular}

FONTE: IBGE.

\section{Década 90}

\begin{tabular}{|c|c|c|c|c|c|c|c|}
\hline \multirow{4}{*}{ Municípios } & \multirow{4}{*}{ Total } & \multicolumn{6}{|c|}{ Pessoas não naturais do município } \\
\hline & & \multicolumn{3}{|c|}{ Urbana } & \multicolumn{3}{|c|}{ Rural } \\
\hline & & \multirow[b]{2}{*}{ Total } & \multicolumn{2}{|c|}{ Situação de residência no município } & \multirow[b]{2}{*}{ Total } & \multicolumn{2}{|c|}{ Situação de residência no município } \\
\hline & & & \begin{tabular}{|c|}
$\begin{array}{c}\text { Sempre moraram nesta } \\
\text { situação }\end{array}$ \\
\end{tabular} & $\begin{array}{l}\text { Já moraram em } \\
\text { situação rural }\end{array}$ & & \begin{tabular}{|c|}
$\begin{array}{c}\text { Sempre moraram nesta } \\
\text { situação }\end{array}$ \\
\end{tabular} & $\begin{array}{l}\text { Já mo raram em } \\
\text { situação urbana }\end{array}$ \\
\hline $\begin{array}{l}\text { Governador } \\
\text { Valadares }\end{array}$ & 100651 & 97040 & 90569 & 6471 & 3611 & 3004 & 607 \\
\hline Juiz de Fora & 136021 & 134625 & 131083 & 3542 & 1396 & 1108 & 288 \\
\hline Poços de Caldas & 52882 & 51181 & 47446 & 3735 & 1701 & 1259 & 442 \\
\hline Montes Claros & 92787 & 89799 & 85523 & 4276 & 2988 & 2253 & 735 \\
\hline Uberlândia & 185390 & 181235 & 171000 & 10235 & 4155 & 2506 & 1649 \\
\hline
\end{tabular}

FONTE: Adaptado de Recenseamento Geral do Brasil de 1991 - Migração - Minas Gerais. 


\section{Década 80}

\begin{tabular}{|c|c|c|c|c|c|c|c|}
\hline \multirow[b]{2}{*}{ Municípios } & \multirow[b]{2}{*}{$\begin{array}{c}\text { Total } \\
\text { (1) }\end{array}$} & \multicolumn{3}{|c|}{ Naturais do município } & \multicolumn{3}{|c|}{ Não naturais do município } \\
\hline & & $\begin{array}{c}\text { Total } \\
\text { (1) }\end{array}$ & $\begin{array}{l}\text { Sempre morou } \\
\text { na situação do } \\
\text { domicilio atual }\end{array}$ & $\begin{array}{c}\text { Já morou em } \\
\text { situação } \\
\text { diferente do } \\
\text { domicilio atual }\end{array}$ & Total & $\begin{array}{l}\text { Sempre morou na } \\
\text { situação do } \\
\text { domicilio atual }\end{array}$ & $\begin{array}{l}\text { Já morou em } \\
\text { situação } \\
\text { diferente do } \\
\text { domicilio atual }\end{array}$ \\
\hline $\begin{array}{l}\text { Governador } \\
\text { Valadares }\end{array}$ & 196117 & 98326 & 88571 & 9673 & 97791 & 89859 & 7818 \\
\hline Juiz de Fora & 307534 & 180209 & 169665 & 10418 & 127325 & 122844 & 4164 \\
\hline Montes Claros & 177302 & 106847 & 91945 & 14792 & 70455 & 65951 & 4220 \\
\hline Poços de Caldas & 86971 & 39597 & 36733 & 2830 & 47374 & 44914 & 2407 \\
\hline Uberlândia & 240967 & 110572 & 94774 & 15733 & 130395 & 117511 & 12376 \\
\hline
\end{tabular}

(1) Inclusive sem declaração de migração no município de residência atual: 10218 naturais do município e 12226 não naturais do município

FONTE: Adaptado de recenseamento Geral do Brasil de 1980 - Minas Gerais. Volume I - Tomo 4 - n. 18 X, p. 428.

\section{Década 80}

\begin{tabular}{|c|c|c|c|c|c|c|}
\hline \multirow{2}{*}{ Lugar do domicilio anterior } & \multicolumn{6}{|c|}{ Municípios } \\
\hline & Governador Valadares & Juiz de Foral & Montes Claros & Poços de Caldas & Uberlândia & UF \\
\hline Rondônia & 83 & 47 & 0 & 0 & 39 & 878 \\
\hline Acre & 0 & 71 & 0 & 0 & 0 & 149 \\
\hline Amazonas & 4 & 67 & 7 & 0 & 0 & 773 \\
\hline Roraima & 3 & 27 & 19 & 0 & 0 & 80 \\
\hline Pará & 118 & 21 & 45 & 20 & 165 & 3044 \\
\hline Amapá & 0 & 0 & 0 & 35 & 0 & 296 \\
\hline Maranhão & 40 & 33 & 10 & 11 & 86 & 2293 \\
\hline Piauí & 0 & 70 & 9 & 8 & 23 & 1329 \\
\hline Ceará & 162 & 61 & 167 & 26 & 181 & 4755 \\
\hline Rio Grande do Norte & 41 & 60 & 16 & 27 & 484 & 3364 \\
\hline Paraíba & 84 & 69 & 24 & 46 & 133 & 2786 \\
\hline Pernambuco & 109 & 129 & 170 & 50 & 180 & 5050 \\
\hline Alagoas & 43 & 34 & 18 & 33 & 15 & 1321 \\
\hline Fernando de Noronha & 0 & 0 & 0 & 0 & 0 & 22 \\
\hline Sergipe & 10 & 11 & 8 & 0 & 4 & 904 \\
\hline Bahia & 1225 & 325 & 1130 & 188 & 250 & 42967 \\
\hline Minas Gerais & 33894 & 37365 & 34825 & 14484 & 51551 & 1866531 \\
\hline Espírito Santo & 1898 & 463 & 106 & 42 & 61 & 33666 \\
\hline Rio de Janeiro & 1446 & 8341 & 319 & 386 & 532 & 63712 \\
\hline São Paulo & 1895 & 2489 & 1695 & 6640 & 5832 & 153383 \\
\hline Paraná & 365 & 377 & 395 & 1270 & 611 & 39514 \\
\hline Santa Catarina & 69 & 112 & 0 & 24 & 74 & 1637 \\
\hline Rio Grande do Sul & 89 & 259 & 14 & 94 & 186 & 4696 \\
\hline Mato Grosso do Sul & 46 & 268 & 15 & 19 & 234 & 3316 \\
\hline Mato Grosso & 138 & 117 & 32 & 23 & 749 & 4457 \\
\hline Goiás & 128 & 162 & 172 & 197 & 21306 & 58011 \\
\hline Distrito Federal & 190 & 522 & 206 & 129 & 1231 & 14389 \\
\hline Sem especificação & 3 & 8 & 10 & 4 & 12 & 318 \\
\hline Exterior & 66 & 127 & 90 & 105 & 237 & 5848 \\
\hline Sem declaração & 111 & 296 & 212 & 20 & 469 & 9224 \\
\hline Total & 42260 & 51921 & 39714 & 23881 & 84645 & 23328713 \\
\hline
\end{tabular}

FONTE: Adaptado de Recenseamento Geral do Brasil de 1980 - Minas Gerais. Volume + Tomo 4 n⿳18 X, Pg.521. 
Década 60.

\begin{tabular}{|l|r|r|r|r|r|}
\hline $\begin{array}{c}\text { Tempo de residência no } \\
\text { município }\end{array}$ & $\begin{array}{c}\text { Juiz de } \\
\text { Fora }\end{array}$ & $\begin{array}{c}\text { Poços de } \\
\text { Caldas }\end{array}$ & $\begin{array}{c}\text { Montes } \\
\text { Claros }\end{array}$ & Uberlândia & $\begin{array}{c}\text { Governador } \\
\text { Valadares }\end{array}$ \\
\hline Menos de 1 ano & 5053 & 2299 & 2461 & 4376 & 10483 \\
\hline 1 ano & & & & & \\
\hline 1 a 5 anos & 13836 & 6178 & 5867 & 11157 & 71137 \\
\hline 6 a 10 anos & 10721 & 3132 & 3576 & 7404 & 13793 \\
\hline 11 anos e mais & 29082 & 7249 & 4298 & 13407 & 16132 \\
\hline
\end{tabular}

FONTE: Adaptado de Recenseamento Geral do Brasil de 1960. Minas Gerais. Série Regional. Volume 1 - Tomo IX.p. 70.

População residente (Variável $=$ População residente $($ Pessoas) ; Sexo = Total; Situação do domicílio $=$ Total)

\begin{tabular}{|l|r|r|r|r|}
\cline { 2 - 5 } \multicolumn{2}{c|}{ Brasil e Município } & \multicolumn{4}{c|}{ Ano } \\
\cline { 2 - 5 } & \multicolumn{1}{c|}{1970} & 1980 & \multicolumn{1}{c|}{1991} & 2000 \\
\hline Brasil & 93.134 .846 & 119.011 .052 & 146.825 .475 & 169.799 .170 \\
\hline Governador Valadares - MG & 162.020 & 196.117 & 230.524 & 247.131 \\
\hline Juiz de Fora - MG & 238.510 & 307.534 & 385.996 & 456.796 \\
\hline Montes Claros - MG & 116.486 & 177.302 & 250.062 & 306.947 \\
\hline Poços de Caldas - MG & 57.565 & 86.971 & 110.123 & 135.627 \\
\hline Uberlândia - MG & 124.706 & 240.967 & 367.061 & 501.214 \\
\hline
\end{tabular}

FONTE: IBGE.

Tabela 156 - Média de moradores por domicílio (Variável = Média de moradores por domicílio (Pessoas))

\begin{tabular}{|l|r|r|}
\multirow{2}{*}{ Brasil e Município } & \multicolumn{2}{c|}{ Ano } \\
\cline { 2 - 3 } & \multicolumn{1}{c|}{1991} & 2000 \\
\hline Brasil & 4,19 & 3,73 \\
\hline Governador Valadares - MG & 4,25 & 3,69 \\
\hline Juiz de Fora - MG & 3,80 & 3,39 \\
\hline Montes Claros - MG & 4,58 & 4,01 \\
\hline Poços de Caldas - MG & 3,77 & 3,37 \\
\hline Uberlândia - MG & 3,88 & 3,44 \\
\hline
\end{tabular}

FONTE: IBGE.

Tabela 185 - Domicílios particulares permanentes por situação e número de moradores (Situação do domicílio = Total ; Número de moradores = Total)

\begin{tabular}{|c|c|c|c|c|}
\hline \multirow{3}{*}{$\begin{array}{l}\text { Brasil, Unidade da Federação e } \\
\text { Município }\end{array}$} & \multicolumn{4}{|c|}{ Variável X Ano } \\
\hline & \multicolumn{2}{|c|}{$\begin{array}{l}\text { Domicílios particulares permanentes } \\
\text { (Unidade) }\end{array}$} & \multicolumn{2}{|c|}{$\begin{array}{l}\text { Domicílios particulares permanentes } \\
\text { (Percentual) }\end{array}$} \\
\hline & 1991 & 2000 & 1991 & 2000 \\
\hline Brasil & 34.734 .715 & 44.795 .101 & 100,00 & 100,00 \\
\hline Minas Gerais & 3.707 .237 & 4.765 .258 & 100,00 & 100,00 \\
\hline Governador Valadares - MG & 53.887 & 65.827 & 100,00 & 100,00 \\
\hline Juiz de Fora - MG & 100.498 & 132.465 & 100,00 & 100,00 \\
\hline Montes Claros - MG & 54.168 & 75.676 & 100,00 & 100,00 \\
\hline Poços de Caldas - MG & 29.045 & 39.701 & 100,00 & 100,00 \\
\hline Uberlândia - MG & 94.086 & 144.461 & 100,00 & 100,00 \\
\hline
\end{tabular}

FONTE: IBGE. 
Tabela 200 - População residente por sexo, situação e grupos de idade (Sexo = Total; Grupos de idade $=$ Total)

\begin{tabular}{|c|c|c|c|c|c|c|c|c|c|}
\hline \multirow{3}{*}{ Brasil e Município } & \multirow{3}{*}{$\begin{array}{c}\text { Situação do } \\
\text { domicílio }\end{array}$} & \multicolumn{8}{|c|}{ Variável X Ano } \\
\hline & & \multicolumn{4}{|c|}{ População residente (Pessoas) } & \multicolumn{4}{|c|}{$\begin{array}{l}\text { População residente } \\
\text { (Percentual) }\end{array}$} \\
\hline & & 1970 & 1980 & 1991 & 2000 & 1970 & 1980 & 1991 & 2000 \\
\hline \multirow{3}{*}{ Brasil } & Total & 93.134 .846 & 119.011 .052 & 146.825 .475 & 169.872 .856 & 100,00 & 100,00 & 100,00 & 100,00 \\
\hline & Urbana & 52.097 .260 & 80.437 .327 & 110.990 .990 & 137.925 .238 & 55,94 & 67,59 & 75,59 & 81,19 \\
\hline & Rural & 41.037 .586 & 38.573 .725 & 35.834 .485 & 31.947 .618 & 44,06 & 32,41 & 24,41 & 18,81 \\
\hline \multirow{3}{*}{$\begin{array}{l}\text { Governador Valadares } \\
\text { MG }\end{array}$} & Total & 162.020 & 196.117 & 230.524 & 247.131 & 100,00 & 100,00 & 100,00 & 100,00 \\
\hline & Urbana & 129.565 & 177.776 & 215.098 & 236.098 & 79,97 & 90,65 & 93,31 & 95,54 \\
\hline & Rural & 32.455 & 18.341 & 15.426 & 11.033 & 20,03 & 9,35 & 6,69 & 4,46 \\
\hline \multirow{3}{*}{ Juiz de Fora - MG } & Total & 238.510 & 307.534 & 385.996 & 456.796 & 100,00 & 100,00 & 100,00 & 100,00 \\
\hline & Urbana & 220.390 & 301.692 & 380.249 & 453.002 & 92,40 & 98,10 & 98,51 & 99,17 \\
\hline & Rural & 18.120 & 5.842 & 5.747 & 3.794 & 7,60 & 1,90 & 1,49 & 0,83 \\
\hline \multirow{3}{*}{ Montes Claros - MG } & Total & 116.486 & 177.302 & 250.062 & 306.947 & 100,00 & 100,00 & 100,00 & 100,00 \\
\hline & \begin{tabular}{|l|} 
Urbana \\
\end{tabular} & 85.147 & 155.295 & 227.759 & 289.183 & 73,10 & 87,59 & 91,08 & 94,21 \\
\hline & Rural & 31.339 & 22.007 & 22.303 & 17.764 & 26,90 & 12,41 & 8,92 & 5,79 \\
\hline \multirow{3}{*}{ Poços de Caldas - MG } & Total & 57.565 & 86.971 & 110.123 & 135.627 & 100,00 & 100,00 & 100,00 & 100,00 \\
\hline & \begin{tabular}{|l|} 
Urbana \\
\end{tabular} & 51.777 & 81.416 & 105.205 & 130.826 & 89,95 & 93,61 & 95,53 & 96,46 \\
\hline & Rural & 5.788 & 5.555 & 4.918 & 4.801 & 10,05 & 6,39 & 4,47 & 3,54 \\
\hline \multirow{3}{*}{ Uberlândia - MG } & Total & 124.706 & 240.967 & 367.061 & 501.214 & 100,00 & 100,00 & 100,00 & 100,00 \\
\hline & Urbana & 111.480 & 231.583 & 358.165 & 488.982 & 89,39 & 96,11 & 97,58 & 97,56 \\
\hline & Rural & 13.226 & 9.384 & 8.896 & 12.232 & 10,61 & 3,89 & 2,42 & 2,44 \\
\hline
\end{tabular}

FONTE: IBGE.

Tabela 1298 - Densidade demográfica nos Censos Demográficos (Variável = Densidade demográfica (Habitante por Quilômetro quadrado))

\begin{tabular}{|c|c|c|c|c|c|}
\hline \multirow{2}{*}{ Brasil e Unidade da Federação } & \multicolumn{5}{|c|}{ Ano } \\
\hline & 1960 & 1970 & 1980 & 1991 & 2000 \\
\hline Brasil & 8,34 & 11,10 & 14,23 & 17,26 & 19,92 \\
\hline Minas Gerais & 16,98 & 19,85 & 23,27 & 26,82 & 30,46 \\
\hline
\end{tabular}

FONTE: IBGE.

Tabela 1301 - Área e Densidade demográfica da unidade territorial $(A n o=2000)$

\begin{tabular}{l|c|c|}
\cline { 2 - 3 } $\begin{array}{c}\text { Brasil, Unidade da } \\
\text { Federação e Município }\end{array}$ & $\begin{array}{c}\text { Área da unidade territorial } \\
\text { (Quilômetro quadrado) }\end{array}$ & $\begin{array}{c}\text { Densidade demográfica da unidade territorial } \\
\text { (Habitante por Quilômetro quadrado) }\end{array}$ \\
\cline { 2 - 3 } & $8.514 .204,9$ & 19,92 \\
\hline Brasil & $586.552,4$ & 30,46 \\
\hline Minas Gerais & $1.261,1$ & $4.640,37$ \\
\hline Rio de Janeiro - RJ & $1.525,0$ & $6.823,68$ \\
\hline São Paulo - SP & $2.348,1$ & 105,17 \\
\hline Governador Valadares - MG & $1.439,1$ & 317,16 \\
\hline Juiz de Fora - MG & $3.582,0$ & 85,63 \\
\hline Montes Claros - MG & 544,3 & 249,08 \\
\hline Poços de Caldas - MG & $4.103,4$ & 121,97 \\
\hline Uberlândia - MG & & \\
\hline FONTE: IBGE & & \\
\hline
\end{tabular}

FONTE: IBGE. 
Tabela 1311 - Número de domicílios e Média de moradores em domicílios particulares ocupados (Situação e localização da área = Urbana - cidade ou vila - área urbanizada; Ano = 2000)

\begin{tabular}{|l|r|r|r|}
\hline \multirow{2}{*}{$\begin{array}{c}\text { Brasil, Unidade da Federação } \\
\text { e Município }\end{array}$} & \multicolumn{3}{|c|}{ Variável } \\
\cline { 2 - 4 } & $\begin{array}{c}\text { Número de domicílios } \\
\text { particulares ocupados } \\
\text { (Unidade) }\end{array}$ & $\begin{array}{c}\text { Número de domicílios } \\
\text { particulares ocupados } \\
\text { (Percentual) }\end{array}$ & $\begin{array}{c}\text { Média de moradores em } \\
\text { domicílios particulares ocupados } \\
\text { (Pessoas) }\end{array}$ \\
\hline Brasil & 36.848 .003 & 81,85 & 3,68 \\
\hline Minas Gerais & 3.917 .064 & 81,89 & 3,68 \\
\hline Governador Valadares - MG & 62.742 & 94,92 & 3,72 \\
\hline Juiz de Fora - MG & 128.934 & 97,10 & 3,43 \\
\hline Montes Claros - MG & 71.442 & 93,98 & 4,05 \\
\hline Poços de Caldas - MG & 38.412 & 96,52 & 3,39 \\
\hline Uberlândia - MG & 141.312 & 97,53 & 3,45 \\
\hline
\end{tabular}

FONTE: IBGE - Censo Demográfico.

Tabela 1435 - Domicílios particulares permanentes e Moradores em Domicílios particulares permanentes por situação e condição de ocupação do domicílio (Situação do domicílio = Total; Ano $=2000)$

\begin{tabular}{|c|l|r|r|r|r|}
\hline \multirow{5}{*}{ Município } & Condição de & \multicolumn{1}{|c|}{ Variável } \\
\cline { 3 - 6 } & $\begin{array}{c}\text { Domicílios } \\
\text { ocupação do } \\
\text { domicílio } \\
\text { perticulares } \\
\text { povanentes } \\
\text { (Unidade) }\end{array}$ & $\begin{array}{c}\text { Domicílios } \\
\text { particulares } \\
\text { permanentes } \\
\text { (Percentual) }\end{array}$ & $\begin{array}{c}\text { Moradores em } \\
\text { domicílios } \\
\text { particulares } \\
\text { permanentes } \\
\text { (Pessoas) }\end{array}$ & $\begin{array}{c}\text { Moradores em } \\
\text { domicílios } \\
\text { particulares } \\
\text { permanentes } \\
\text { (Percentual) }\end{array}$ \\
\hline \multirow{2}{*}{ Juiz de Fora - MG } & Total & 65.827 & 100,00 & 245.281 & 100,00 \\
\cline { 2 - 6 } & Próprio & 44.540 & 67,66 & 171.807 & 70,04 \\
\hline \multirow{2}{*}{ Montes Claros - MG } & Total & 132.465 & 100,00 & 453.698 & 100,00 \\
\cline { 2 - 6 } & Próprio & 93.824 & 70,83 & 332.243 & 73,23 \\
\hline \multirow{2}{*}{ Poços de Caldas - MG } & Total & 75.676 & 100,00 & 305.006 & 100,00 \\
\cline { 2 - 6 } & Próprio & 59.703 & 78,89 & 248.367 & 81,43 \\
\hline \multirow{2}{*}{ Uberlândia - MG } & Total & 39.701 & 100,00 & 134.779 & 100,00 \\
\cline { 2 - 6 } & Próprio & 24.199 & 60,95 & 84.291 & 62,54 \\
\hline
\end{tabular}

FONTE IBGE - Censo Demográfico.

Tabela 1436 - Domicílios particulares permanentes e Moradores em Domicílios particulares permanentes por situação e abastecimento de água (Situação do domicílio = Total; Forma de abastecimento de água $=$ Rede geral $;$ Ano $=2000$ )

\begin{tabular}{|l|c|r|r|r|}
\hline \multirow{2}{*}{ Brasil e Município } & \multicolumn{4}{|c|}{ Variável } \\
\cline { 2 - 5 } & $\begin{array}{c}\text { Domicílios } \\
\text { particulares } \\
\text { permanentes } \\
\text { (Unidade) }\end{array}$ & $\begin{array}{c}\text { Domicílios } \\
\text { particulares } \\
\text { permanentes } \\
\text { (Percentual) }\end{array}$ & $\begin{array}{c}\text { Moradores em } \\
\text { domicílios } \\
\text { particulares } \\
\text { permanentes } \\
\text { (Pessoas) }\end{array}$ & $\begin{array}{c}\text { Moradores em } \\
\text { domicílios } \\
\text { particulares } \\
\text { permanentes } \\
\text { (Percentual) }\end{array}$ \\
\hline Brasil & 34.859 .393 & 77,82 & 127.682 .948 & 75,83 \\
\hline Governador Valadares - MG & 62.172 & 94,45 & 231.282 & 94,29 \\
\hline Juiz de Fora - MG & 126.245 & 95,30 & 431.050 & 95,01 \\
\hline Montes Claros - MG & 70.129 & 92,67 & 283.250 & 92,87 \\
\hline Poços de Caldas - MG & 37.742 & 95,07 & 127.525 & 94,62 \\
\hline Uberlândia - MG & 141.113 & 97,68 & 487.357 & 97,62 \\
\hline
\end{tabular}

FONTE: IBGE - Censo Demográfico. 
Tabela 1437 - Domicílios particulares permanentes e Moradores em Domicílios particulares permanentes por situação e tipo do esgotamento sanitário (Situação do domicílio = Total; Tipo de esgotamento sanitário $=$ Rede geral de esgoto ou pluvial; $A$ no $=2000$ ).

\begin{tabular}{|l|c|r|r|r|}
\hline & \multicolumn{4}{|c|}{ Variável } \\
\cline { 2 - 5 } \multicolumn{1}{c|}{ Brasil e Município } & $\begin{array}{c}\text { Domicílios } \\
\text { particulares } \\
\text { permanentes } \\
\text { (Unidade) }\end{array}$ & $\begin{array}{c}\text { Domicílios } \\
\text { particulares } \\
\text { permanentes } \\
\text { (Percentual) }\end{array}$ & $\begin{array}{c}\text { Moradores em } \\
\text { domicílios } \\
\text { particulares } \\
\text { permanentes } \\
\text { (Pessoas) }\end{array}$ & $\begin{array}{c}\text { Moradores em } \\
\text { domicílios } \\
\text { particulares } \\
\text { permanentes } \\
\text { (Percentual) }\end{array}$ \\
\hline Brasil & 21.160 .735 & 47,24 & 74.721 .700 & 44,38 \\
\hline Governador Valadares - MG & 53.535 & 81,33 & 197.563 & 80,55 \\
\hline Juiz de Fora - MG & 123.522 & 93,25 & 421.216 & 92,84 \\
\hline Montes Claros - MG & 64.653 & 85,43 & 261.075 & 85,60 \\
\hline Poços de Caldas - MG & 37.288 & 93,92 & 125.966 & 93,46 \\
\hline Uberlândia - MG & 138.719 & 96,03 & 478.649 & 95,88 \\
\hline
\end{tabular}

FONTE: IBGE - Censo Demográfico.

Tabela 1438 - Domicílios particulares permanentes e Moradores em Domicílios particulares permanentes por situação e número de banheiros (Situação do domicílio = Total; $A n o=2000$ )

\begin{tabular}{|c|c|c|c|c|c|}
\hline \multirow[b]{2}{*}{$\begin{array}{l}\text { Brasil, Unidade da } \\
\text { Federação e Município }\end{array}$} & \multirow[b]{2}{*}{$\begin{array}{l}\text { Número de } \\
\text { banheiros }\end{array}$} & \multicolumn{4}{|c|}{ Variável } \\
\hline & & $\begin{array}{c}\text { Domicílios } \\
\text { particulares } \\
\text { permanentes } \\
\text { (Unidade) }\end{array}$ & $\begin{array}{c}\text { Domicílios } \\
\text { particulares } \\
\text { permanentes } \\
\text { (Percentual) }\end{array}$ & $\begin{array}{c}\text { Moradores em } \\
\text { domicílios } \\
\text { particulares } \\
\text { permanentes } \\
\text { (Pessoas) } \\
\end{array}$ & $\begin{array}{l}\text { Moradores em } \\
\text { domicílios } \\
\text { particulares } \\
\text { permanentes } \\
\text { (Percentual) } \\
\end{array}$ \\
\hline \multirow{2}{*}{ Brasil } & Total & 44.795 .101 & 100,00 & 168.370 .893 & 100,00 \\
\hline & Não tinham & 7.501 .348 & 16,75 & 32.251 .068 & 19,15 \\
\hline \multirow{2}{*}{ Minas Gerais } & \begin{tabular}{|l|} 
Total \\
\end{tabular} & 4.765 .258 & 100,00 & 17.762 .368 & 100,00 \\
\hline & Não tinham & 435.310 & 9,14 & 1.760 .642 & 9,91 \\
\hline \multirow{2}{*}{ Governador Valadares - MG } & \begin{tabular}{|l|} 
Total \\
\end{tabular} & 65.827 & 100,00 & 245.281 & 100,00 \\
\hline & \begin{tabular}{|l|} 
Não tinham \\
\end{tabular} & 4.705 & 7,15 & 17.671 & 7,20 \\
\hline \multirow{2}{*}{ Juiz de Fora - MG } & Total & 132.465 & 100,00 & 453.698 & 100,00 \\
\hline & \begin{tabular}{|l|} 
Não tinham \\
\end{tabular} & 1.243 & 0,94 & 4.080 & 0,90 \\
\hline \multirow{2}{*}{ Montes Claros - MG } & Total & 75.676 & 100,00 & 305.006 & 100,00 \\
\hline & Não tinham & 7.101 & 9,38 & 27.884 & 9,14 \\
\hline \multirow{2}{*}{ Poços de Caldas - MG } & Total & 39.701 & 100,00 & 134.779 & $\overline{100,00}$ \\
\hline & \begin{tabular}{|l|} 
Não tinham \\
\end{tabular} & 278 & 0,70 & 820 & 0,61 \\
\hline \multirow{2}{*}{ Uberlândia - MG } & Total & 144.461 & 100,00 & 499.223 & 100,00 \\
\hline & Não tinham & 1.727 & 1,20 & 5.376 & 1,08 \\
\hline
\end{tabular}

FONTE: IBGE - Censo Demográfico

Domicílios particulares permanentes e Moradores em Domicílios particulares permanentes por situação e destino do lixo (Situação do domicílio = Total; Destino do lixo = Coletado; Ano = 2000)

\begin{tabular}{|c|c|c|c|c|}
\hline \multirow[b]{2}{*}{$\begin{array}{l}\text { Brasil, Unidade da } \\
\text { Federação e Município }\end{array}$} & \multicolumn{4}{|c|}{ Variável } \\
\hline & $\begin{array}{c}\text { Domicílios } \\
\text { particulares } \\
\text { permanentes } \\
\text { (Unidade) }\end{array}$ & $\begin{array}{c}\text { Domicílios } \\
\text { particulares } \\
\text { permanentes } \\
\text { (Percentual) }\end{array}$ & $\begin{array}{c}\text { Moradores em } \\
\text { domicílios particulares } \\
\text { permanentes (Pessoas) }\end{array}$ & $\begin{array}{c}\text { Moradores em } \\
\text { domicílios particulares } \\
\text { permanentes } \\
\text { (Percentual) }\end{array}$ \\
\hline Brasil & 35.393 .331 & 79,01 & 128.668 .915 & 76,42 \\
\hline Minas Gerais & 3.733 .665 & 78,35 & 13.648 .358 & 76,84 \\
\hline Governador Valadares - MG & 57.041 & 86,65 & 210.204 & 85,70 \\
\hline Juiz de Fora - MG & 130.308 & 98,37 & 445.527 & 98,20 \\
\hline Montes Claros - MG & 69.115 & 91,33 & 279.293 & 91,57 \\
\hline Poços de Caldas - MG & 38.634 & 97,31 & 130.619 & 96,91 \\
\hline Uberlândia - MG & 140.966 & 97,58 & 486.996 & 97,55 \\
\hline
\end{tabular}

FONTE: IBGE. 
Domicílios particulares permanentes por número de moradores, situação do domicílio e condição de ocupação do domicílio (Número de moradores = Total; Situação do domicílio = Total; Ano = 2000).

\begin{tabular}{l|l|r|r|}
\hline \multirow{2}{*}{ Brasil e Município } & \multicolumn{1}{|c|}{$\begin{array}{c}\text { Condição de } \\
\text { ocupação do } \\
\text { domicílio }\end{array}$} & $\begin{array}{c}\text { Vomicílios particulares } \\
\text { permanentes (Unidade) }\end{array}$ & $\begin{array}{r}\text { Domicílios particulares } \\
\text { permanentes (Percentual) }\end{array}$ \\
\cline { 3 - 4 } & & 44.795 .101 & 100,00 \\
\hline \multirow{2}{*}{ Brasil } & Total & 30.248 .669 & 67,53 \\
\cline { 2 - 4 } & Próprio já quitado & 65.827 & 100,00 \\
\hline \multirow{2}{*}{ Governador Valadares - MG } & Total & 41.886 & 63,63 \\
\cline { 2 - 4 } & Próprio já quitado & 132.465 & 100,00 \\
\hline \multirow{2}{*}{ Juiz de Fora - MG } & Total & 86.719 & 65,47 \\
\cline { 2 - 4 } & Próprio já quitado & 75.676 & 100,00 \\
\hline \multirow{2}{*}{ Montes Claros - MG } & Total & 56.714 & 74,94 \\
\cline { 2 - 4 } & Próprio já quitado & 39.701 & 100,00 \\
\hline \multirow{2}{*}{ Poços de Caldas - MG } & Total & 20.460 & 51,54 \\
\cline { 2 - 4 } & Próprio já quitado & 144.461 & 100,00 \\
\hline \multirow{2}{*}{ Uberlândia - MG } & Total & 69.040 & 47,79 \\
\cline { 2 - 4 } & Próprio já quitado & & \\
\hline
\end{tabular}

FONTE: IBGE.

Famílias residentes em domicílios particulares por classes de rendimento nominal mensal familiar per capita e tipo de composição familiar (Tipo de composição familiar = Total; $A n o=$ 2000).

\begin{tabular}{|c|c|c|c|}
\hline \multirow[b]{2}{*}{$\begin{array}{l}\text { Brasil, Unidade da } \\
\text { Federação e Município }\end{array}$} & \multirow[b]{2}{*}{$\begin{array}{l}\text { Classes de rendimento nominal } \\
\text { mensal familiar per capita }\end{array}$} & \multicolumn{2}{|c|}{ Variável } \\
\hline & & $\begin{array}{c}\text { Famílias residentes em } \\
\text { domicílios particulares } \\
\text { (Unidade) }\end{array}$ & \begin{tabular}{|c|}
$\begin{array}{c}\text { Famílias residentes em } \\
\text { domicílios particulares } \\
\text { (Percentual) }\end{array}$ \\
\end{tabular} \\
\hline \multirow{3}{*}{ Brasil } & Até $1 / 8$ de salário mínimo & 1.056 .745 & 2,19 \\
\hline & Mais de 1/8 a 1/4 de salário mínimo & 2.745 .422 & 5,69 \\
\hline & Mais de $1 / 4$ a 1/2 salário mínimo & 6.755 .271 & 14,00 \\
\hline \multirow{3}{*}{ Minas Gerais } & Até $1 / 8$ de salário mínimo & 69.711 & 1,37 \\
\hline & Mais de 1/8 a 1/4 de salário mínimo & 256.605 & 5,04 \\
\hline & Mais de $1 / 4$ a 1/2 salário mínimo & 753.131 & 14,78 \\
\hline \multirow{3}{*}{ Governador Valadares - MG } & Até $1 / 8$ de salário mínimo & 539 & 0,76 \\
\hline & Mais de 1/8 a 1/4 de salário mínimo & 3.410 & 4,83 \\
\hline & Mais de $1 / 4$ a 1/2 salário mínimo & 9.922 & 14,04 \\
\hline \multirow{3}{*}{ Juiz de Fora - MG } & Até $1 / 8$ de salário mínimo & 435 & 0,31 \\
\hline & Mais de 1/8 a 1/4 de salário mínimo & 2.643 & 1,87 \\
\hline & Mais de $1 / 4$ a 1/2 salário mínimo & 11.821 & 8,35 \\
\hline \multirow{3}{*}{ Montes Claros - MG } & Até $1 / 8$ de salário mínimo & 1.014 & 1,24 \\
\hline & Mais de 1/8 a 1/4 de salário mínimo & 5.523 & 6,74 \\
\hline & Mais de $1 / 4$ a 1/2 salário mínimo & 15.041 & 18,34 \\
\hline \multirow{3}{*}{ Poços de Caldas - MG } & Até $1 / 8$ de salário mínimo & 38 & 0,09 \\
\hline & Mais de 1/8 a 1/4 de salário mínimo & 405 & 0,96 \\
\hline & Mais de $1 / 4$ a 1/2 salário mínimo & 2.494 & 5,93 \\
\hline \multirow{3}{*}{ Uberlândia - MG } & Até $1 / 8$ de salário mínimo & 322 & 0,21 \\
\hline & Mais de 1/8 a 1/4 de salário mínimo & 2.037 & 1,33 \\
\hline & Mais de $1 / 4$ a $1 / 2$ salário mínimo & 12.225 & 7,97 \\
\hline
\end{tabular}

FONTE: IBGE. 
Domicílios particulares permanentes e Moradores em Domicílios particulares permanentes por situação do domicílio e densidade de moradores por dormitório (Situação do domicílio = Total; Ano $=2000$ ).

\begin{tabular}{|c|c|c|c|c|c|}
\hline \multirow[b]{2}{*}{$\begin{array}{c}\text { Brasil, Unidade } \\
\text { da Federação e } \\
\text { Município }\end{array}$} & \multirow[b]{2}{*}{$\begin{array}{c}\text { Densidade de moradores } \\
\text { por dormitório }\end{array}$} & \multicolumn{4}{|c|}{ Variável } \\
\hline & & $\begin{array}{c}\text { Domicílios } \\
\text { particulares } \\
\text { permanentes } \\
\text { (Unidade) }\end{array}$ & $\begin{array}{c}\text { Domicílios } \\
\text { particulares } \\
\text { permanentes } \\
\text { (Percentual) }\end{array}$ & $\begin{array}{c}\text { Moradores em } \\
\text { domicílios } \\
\text { particulares } \\
\text { permanentes } \\
\text { (Pessoas) }\end{array}$ & $\begin{array}{c}\text { Moradores em } \\
\text { domicílios } \\
\text { particulares } \\
\text { permanentes } \\
\text { (Percentual) }\end{array}$ \\
\hline \multirow{2}{*}{ Brasil } & Mais de 2,0 a 3,0 moradores & 8.087 .783 & 18,06 & 40.131 .501 & 23,82 \\
\hline & Mais de 3,0 moradores & 4.299 .495 & 9,60 & 25.656 .687 & 15,23 \\
\hline \multirow{2}{*}{ Minas Gerais } & Mais de 2,0 a 3,0 moradores & 735.387 & 15,44 & 3.770 .864 & 21,21 \\
\hline & Mais de 3,0 moradores & 304.567 & 6,39 & 1.802 .716 & 10,14 \\
\hline \multirow{2}{*}{$\begin{array}{l}\text { Governador } \\
\text { Valadares - MG }\end{array}$} & Mais de 2,0 a 3,0 moradores & 11.248 & 17,08 & 54.901 & 22,40 \\
\hline & Mais de 3,0 moradores & 5.653 & 8,59 & 31.497 & 12,85 \\
\hline \multirow{2}{*}{$\begin{array}{l}\text { Juiz de Fora } \\
\text { MG }\end{array}$} & Mais de 2,0 a 3,0 moradores & 15.744 & 11,90 & 76.305 & 16,81 \\
\hline & Mais de 3,0 moradores & 6.371 & 4,81 & 37.076 & 8,17 \\
\hline \multirow{2}{*}{$\begin{array}{l}\text { Montes Claros - } \\
\text { MG }\end{array}$} & Mais de 2,0 a 3,0 moradores & 14.931 & 19,75 & 76.681 & 25,14 \\
\hline & Mais de 3,0 moradores & 7.730 & 10,23 & 44.108 & 14,46 \\
\hline \multirow{2}{*}{$\begin{array}{l}\text { Poços de Caldas } \\
\text { - MG }\end{array}$} & Mais de 2,0 a 3,0 moradores & 5.535 & 13,95 & 26.041 & 19,32 \\
\hline & Mais de 3,0 moradores & 1.818 & 4,58 & 9.153 & 6,79 \\
\hline \multirow{2}{*}{ Uberlândia - MG } & Mais de 2,0 a 3,0 moradores & 16.679 & 11,55 & 80.705 & 16,16 \\
\hline & Mais de 3,0 moradores & 5.888 & 4,08 & 29.911 & 5,99 \\
\hline
\end{tabular}

FONTE: IBGE.

Domicílios particulares permanentes e Moradores em Domicílios particulares permanentes por densidade de moradores por cômodo (Densidade de moradores por cômodo $=$ Mais de 2,0 moradores; $A$ no $=2000$ ).

\begin{tabular}{|c|c|c|c|c|}
\hline \multirow[b]{2}{*}{$\begin{array}{l}\text { Brasil e Unidade } \\
\text { da Federação }\end{array}$} & \multicolumn{4}{|c|}{ Variável } \\
\hline & $\begin{array}{l}\text { Domicílios particulares } \\
\text { permanentes (Unidade) }\end{array}$ & $\begin{array}{c}\text { Domicílios particulares } \\
\text { permanentes } \\
\text { (Percentual) }\end{array}$ & $\begin{array}{l}\text { Coeficiente de } \\
\text { variação } \\
\text { (Percentual) }\end{array}$ & $\begin{array}{l}\text { Moradores em domicílios } \\
\text { particulares permanentes } \\
\text { (Pessoas) }\end{array}$ \\
\hline Brasil & 1.275 .653 & 2,86 & 2,6 & 9.038 .446 \\
\hline Minas Gerais & 48.656 & 1,02 & 10,9 & 327.329 \\
\hline
\end{tabular}

FONTE: IBGE. 
AUTORIZO A REPRODUÇÃO E DIVULGAÇÃO TOTAL OU PARCIAL DESTE TRABALHO, POR QUALQUER MEIO CONVENCIONAL OU ELETRÔNICO, PARA FINS DE ESTUDO E PESQUISA, DESDE QUE CITADA A FONTE.

ASSINATURA:

E-MAIL: betean@terra.com.br

Andrade, Elisabete de.

A553s A sustentabilidade apoiada pelas políticas urbanas federais e estaduais: 0 caso de Governador Valadares, Juiz de Fora, Montes Claros, Poços de Caldas e Uberlândia - MG./ Elisabete de Andrade. -São Paulo, 2006.

222 p. : il.

Tese (Doutorado - Área de Concentração: Planejamento Urbano e Regional) - FAUUSP.

Orientadora: Gilda Collet Bruna

1. Planejamento territorial urbano - Minas Gerais 2. Política urbana - Minas Gerais 3. Desenvolvimento sustentável - Minas Gerais I.

Título 